\title{
An Examination of Cyanotoxins and Environmental Estrogens in the Middle and Upper Potomac River Watershed, USA
}

\author{
Ryan Patrick Braham
}

Follow this and additional works at: https://researchrepository.wvu.edu/etd

\section{Recommended Citation}

Braham, Ryan Patrick, "An Examination of Cyanotoxins and Environmental Estrogens in the Middle and Upper Potomac River Watershed, USA" (2018). Graduate Theses, Dissertations, and Problem Reports. 5253.

https://researchrepository.wvu.edu/etd/5253

This Dissertation is protected by copyright and/or related rights. It has been brought to you by the The Research Repository @ WVU with permission from the rights-holder(s). You are free to use this Dissertation in any way that is permitted by the copyright and related rights legislation that applies to your use. For other uses you must obtain permission from the rights-holder(s) directly, unless additional rights are indicated by a Creative Commons license in the record and/ or on the work itself. This Dissertation has been accepted for inclusion in WVU Graduate Theses, Dissertations, and Problem Reports collection by an authorized administrator of The Research Repository @ WVU.

For more information, please contact researchrepository@mail.wvu.edu. 


\title{
An examination of cyanotoxins and environmental estrogens in the middle and upper Potomac River watershed, USA
}

\author{
Ryan Patrick Braham \\ Dissertation submitted to the \\ Davis College of Agriculture, Natural Resource and Design \\ at West Virginia University \\ in partial fulfillment of the requirements \\ for the degree of \\ Doctor of Philosophy in \\ Forest Resources Science
}

\author{
Patricia Mazik, Ph.D., Committee Chair \\ Vicki S. Blazer, Ph.D. \\ Jim D. Hedrick, M.S. \\ Amy B. Welsh, Ph.D. \\ George T. Merovich, Ph.D.
}

Wildlife and Fisheries Resources Program

Morgantown, West Virginia

2018

Keywords: Cyanobacteria, Micropterus dolomieu, Moxostoma erythrurum, ELISA, Microcystin, Periphyton, Transcript abundance, Hepatocyte, Leukocyte, Estrogen Equivalent Concentration, Phytoestrogen, Microcystin, Saccharomyces cerevisiae, EEQ

Copyright 2018 Ryan Patrick Braham 


\section{Abstract \\ An examination of cyanotoxins and environmental estrogens in the middle and upper Potomac River watershed, USA}

Ryan Patrick Braham

The Potomac River is a large tributary of the Chesapeake Bay. Large fish die-offs were reported in the Potomac watershed (specifically the South Branch of the Potomac) in 2002 and 2005, as well as smaller episodic events in recent years which have no clear correlation to any one pathogen or contaminant. Although a variety of pathogens have been identified (such as trematodes, myxozoans, Aeromonas hydrophila, A. salmonicida, Flavobacterium columnare, and largemouth bass virus) in recent die-offs of smallmouth bass Micropterus dolomieu, no clear cause has been derived. Additionally, reproductive endpoints were reported in smallmouth bass and likely associated with instream estrogenic compounds. There has been increasing support for estrogenic compounds associated with agricultural runoff as one of the causes. However, there are little data on the contribution from primary producers such as cyanobacteria. Harmful algal blooms are of increasing concern to human health worldwide and their effects on the aquatic community within the South Branch Potomac watershed is largely unknown. To address knowledge gaps associated with fish health in the South Branch Potomac watershed, an assessment of the temporal and spatial distribution of algal toxins and environmental estrogens was required. This dissertation addresses: 1) the spatial and temporal distribution of cyanobacterial toxins in water, periphyton, and fish tissue; 2) the transcriptional response of smallmouth bass hepatocytes and leukocytes challenged with the cyanobacterial toxin microcystin-LR; 3) the spatial and temporal distribution of environmental estrogens in water and 
periphyton and their association with phytoestrogen presence and cyanobacterial toxins; and 4) an assessment of reporter interference in water and periphyton samples. 


\section{Dedication}

For Missy 


\section{Acknowledgements}

I would like to thank the West Virginia Division of Natural Resources and the United States Geological Survey's Environmental Health and Ecosystem (Chesapeake Bay) programs for funding this research. I would to acknowledge my committee Vicki Blazer, Pat Mazik, Jim Hedrick, Amy Welsh and George Merovich. Numerous people at the USGS Leetown Science Center helped with this research including Luke Iwanowicz, Heather Walsh, Cassidy Shaw, Rachel Harrison, Adam Sperry, Cheyenne Smith, Chris Ottinger, Jesse Miles, and Jennifer Jones. I would like to thank the personnel at the West Virginia Division of Natural Resources and Maryland Department of Natural Resources for help with fish collections. I would like to thank my family and friends for helping me along the way. Finally, I would like to thank my wife Missy for always providing me with the inspiration to move forward. 


\section{Foreword}

This dissertation is comprised of five chapters and has been written in the style of manuscripts associated with journals. Chapter two is written in the format of Environmental Monitoring and Assessment. Chapter three is written in the format of Journal of Comparative Biochemistry and Physiology: Part D. Chapter four is written in the style of Water Research. Chapter five is written in the format of Cytometry Part A. 


\section{Table of Contents}

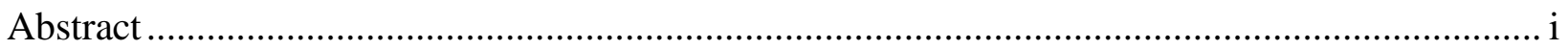

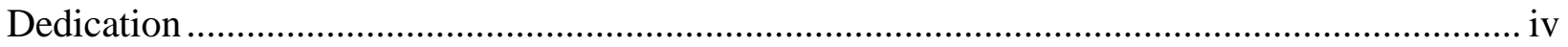

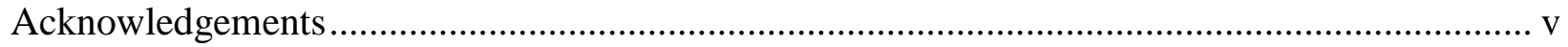

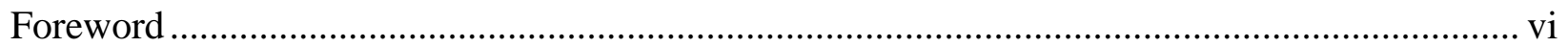

Chapter One. Introduction and Literature Review................................................................ 1

Microcystins in the aquatic environment and fish tissue ........................................................ 1

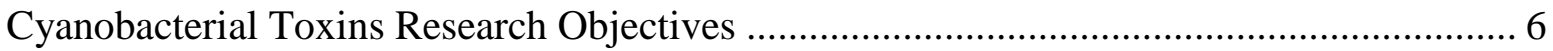

Evaluation of transcript abundance and possible association with total microcystins ............... 7

Influence of microcystin on the transcriptional leukocyte response of fishes to a bacterial

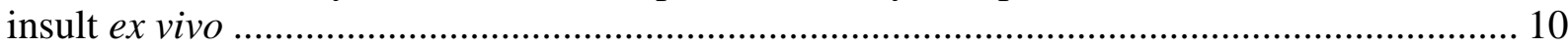

Smallmouth Bass Hepatic and Leukocyte Transcriptional Abundance Research Objectives

Associations among estrogenic activity, select chemical compounds and microcystin toxins 14

Environmental Estrogens Research Objectives .................................................................. 18

Evaluation of possible interference as reported by the yeast strain Saccharomyces cerevisiae

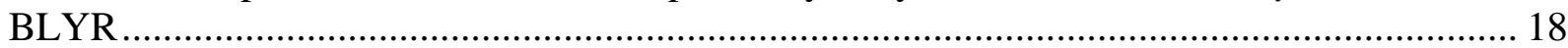

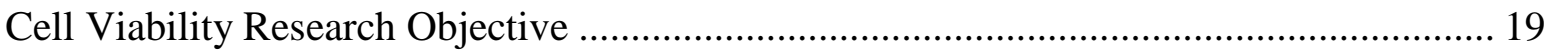

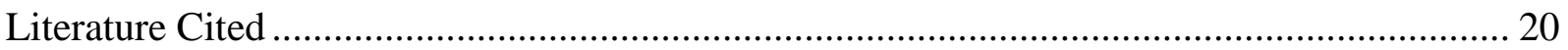

Chapter Two. Temporal associations among cyanotoxins in water and fish tissue at various sites in the upper and middle Potomac River drainage, USA ........................................................... 27

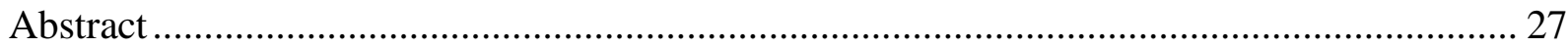

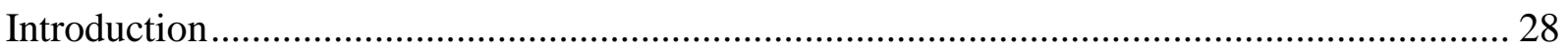

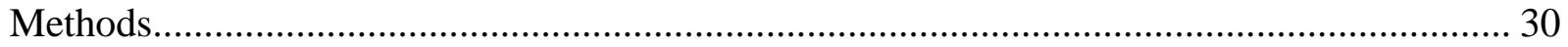

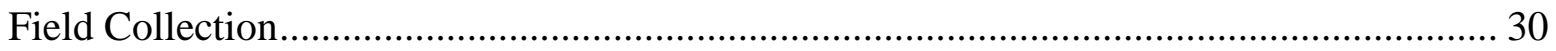

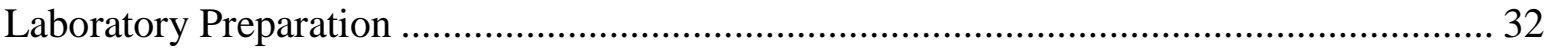

Direct competitive ELISA protocol ........................................................................... 34

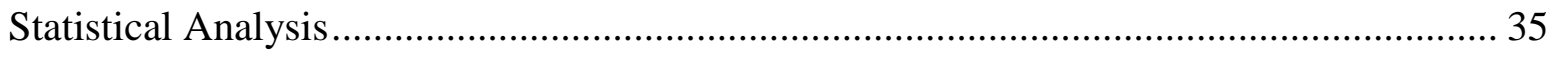

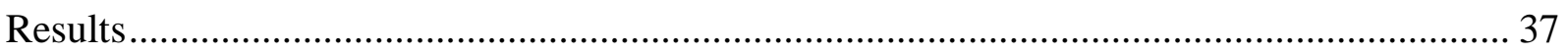

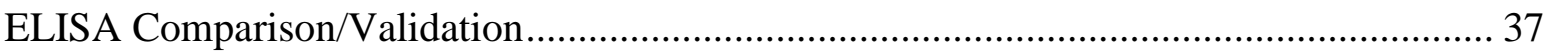

Quantification of Total Microcystins in Water Samples .................................................... 37

Site and Seasonal Differences among Water and Periphyton Samples ............................... 38

Explanatory Variable Data Analysis for Water and Periphyton Samples ............................ 39 
Total Microcystins in Liver Samples .............................................................................. 40

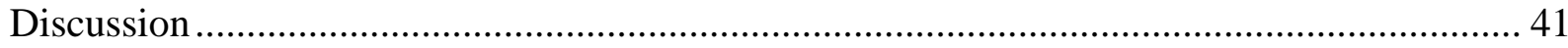

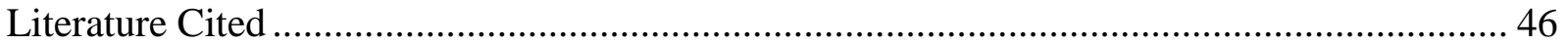

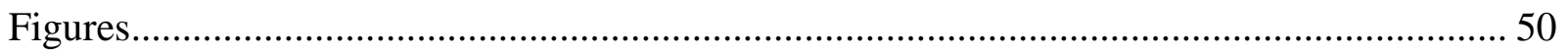

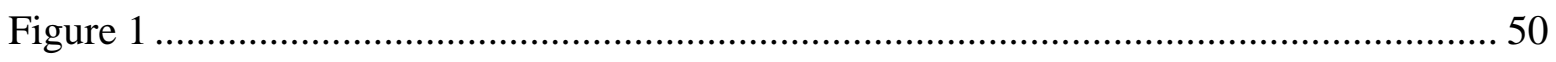

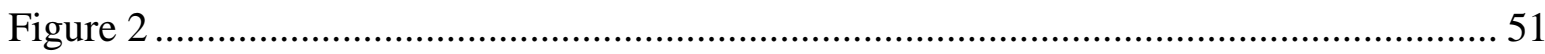

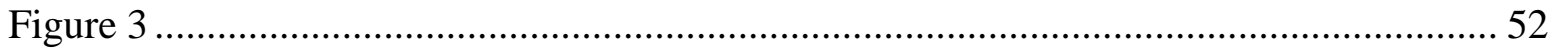

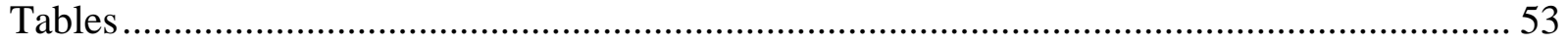

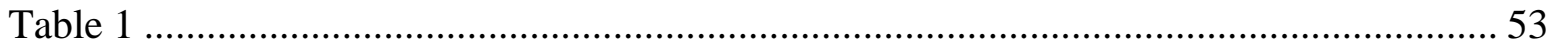

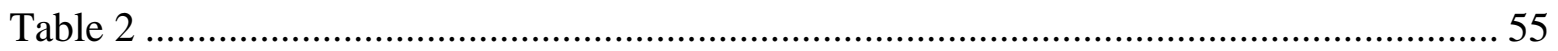

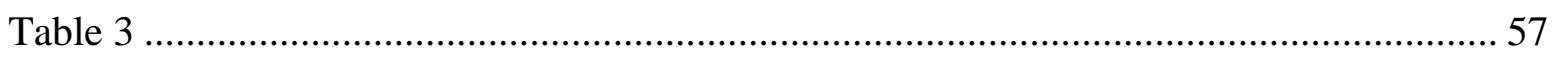

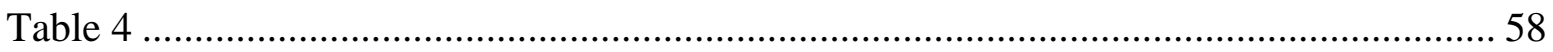

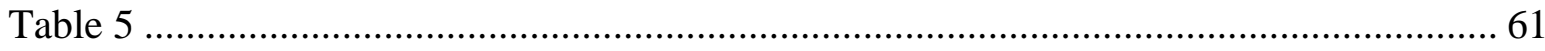

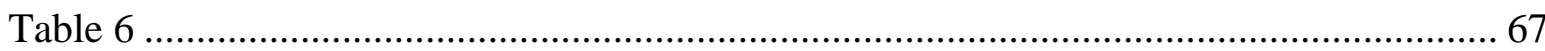

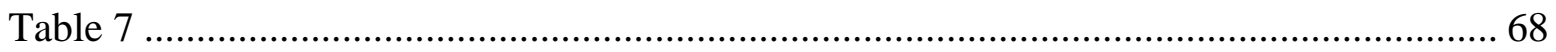

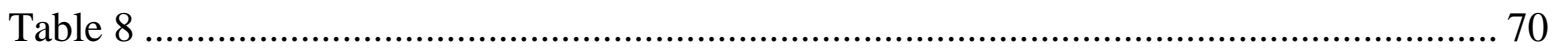

Chapter Three: Hepatocyte and Leukocyte Transcript Abundance Profiles of Smallmouth Bass (Micropterus dolomieu) Challenged with Microcystin-LR ........................................................ 72

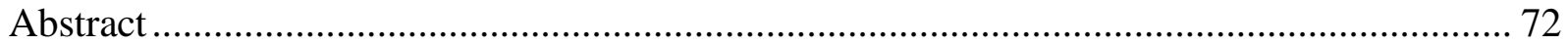

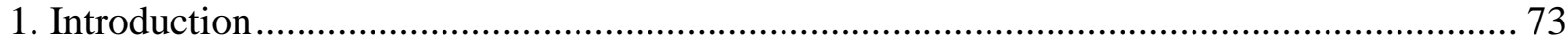

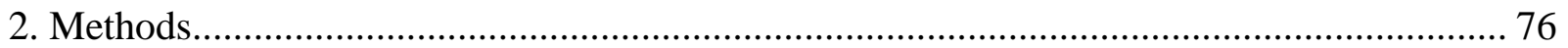

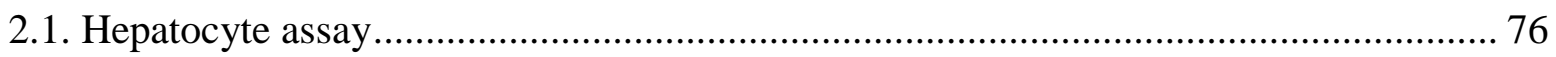

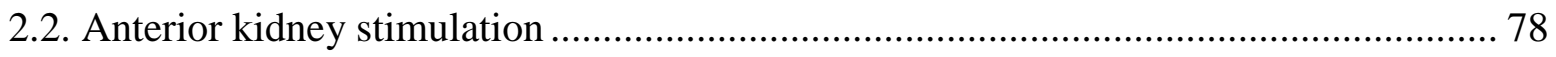

2.3. RNA isolation and sequencing........................................................................... 79

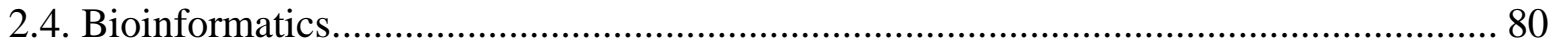

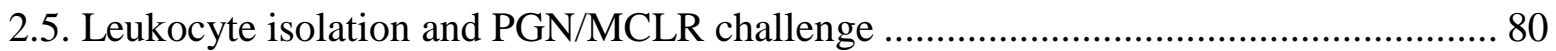

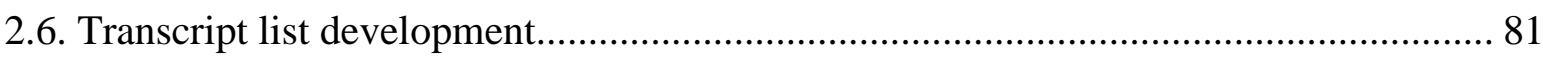

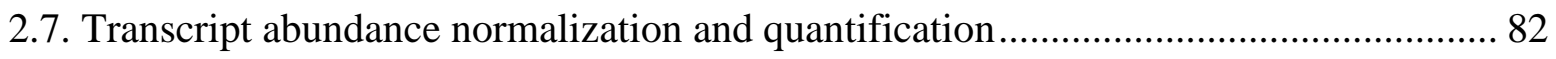

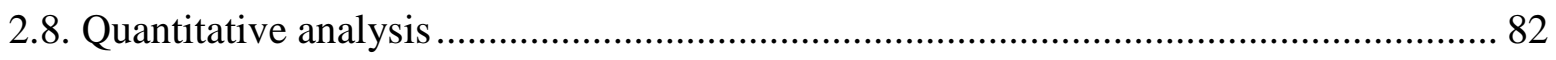

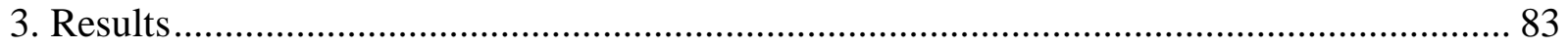

3.1. Transcript abundance using hepatocyte assay ……....................................................... 83

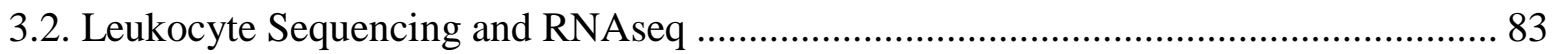

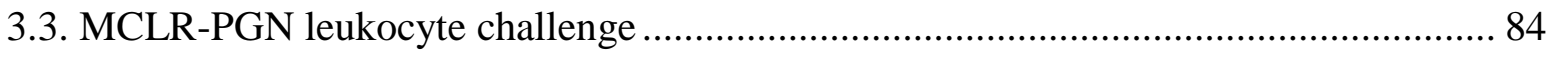




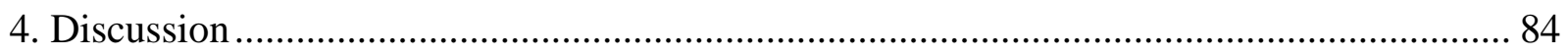

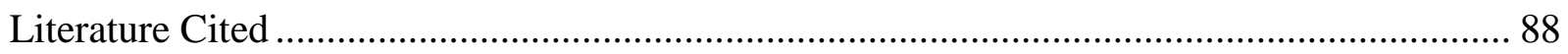

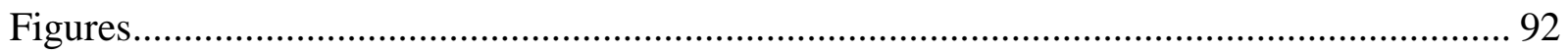

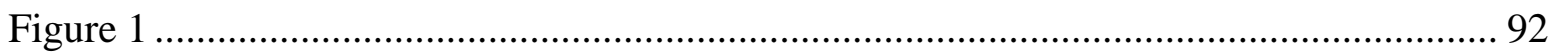

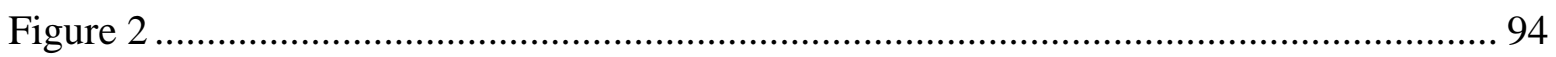

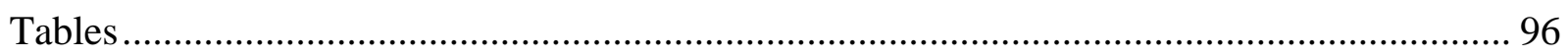

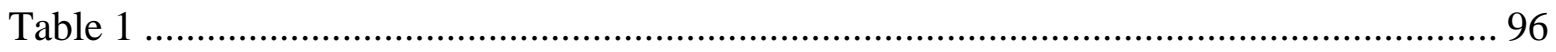

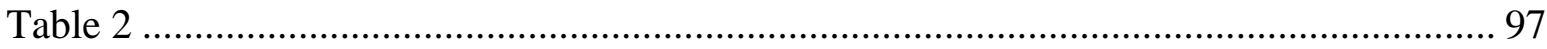

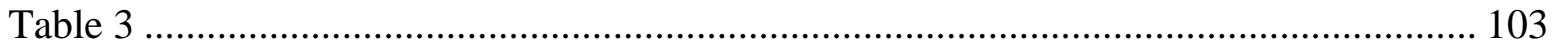

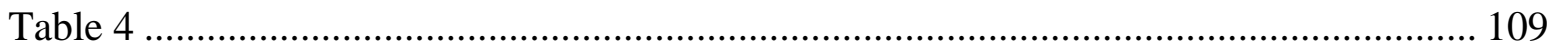

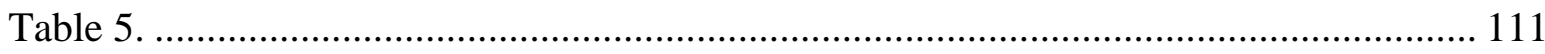

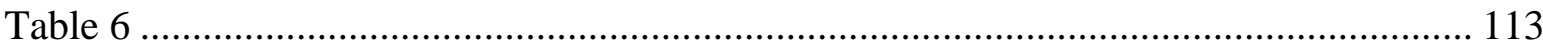

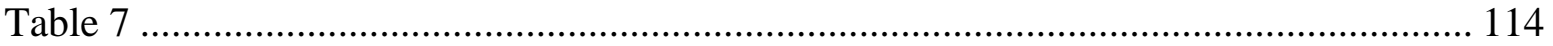

Chapter Four. Associations among estrogenic activity, select chemical compounds and microcystin toxins in the Potomac River drainage, USA ………............................................ 117

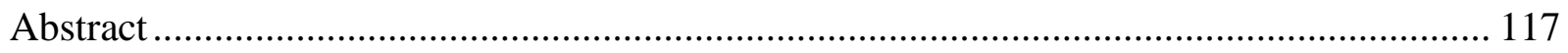

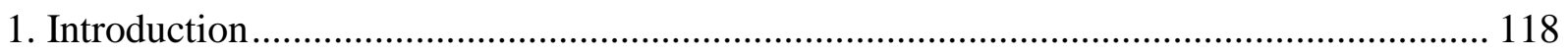

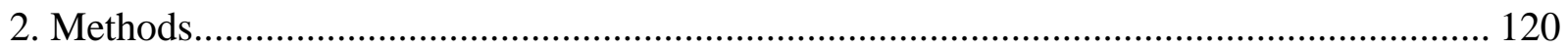

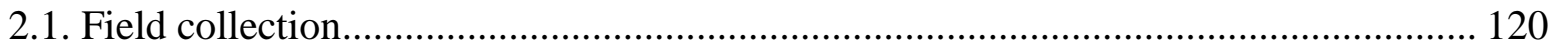

2.2. Laboratory preparation................................................................................... 122

2.3. Bioluminescent Yeast Estrogenicity Screen (BLYES) ............................................. 123

2.4. Direct competitive enzyme-linked immunosorbent assay (ELISA) protocol............... 124

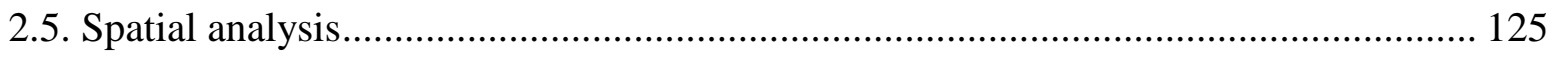

2.6. Statistical analysis .......................................................................................... 125

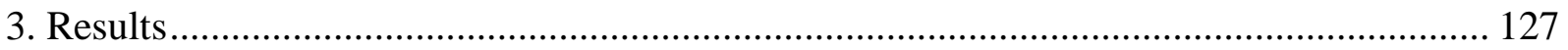

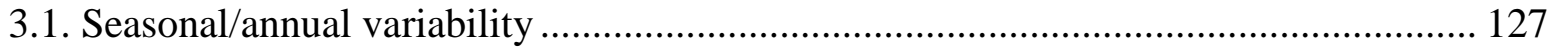

3.2. Variability among season/year pooled across sites..................................................... 128

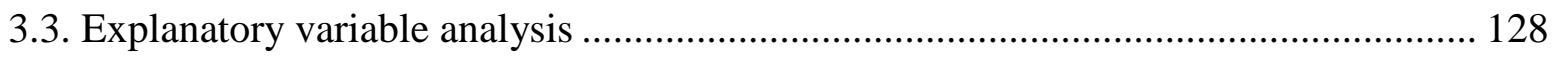

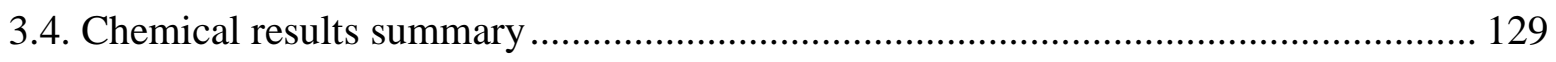

3.5. Land cover analysis..................................................................................... 130

3.6. Comparison of MC-LR and estrogenicity................................................................. 130

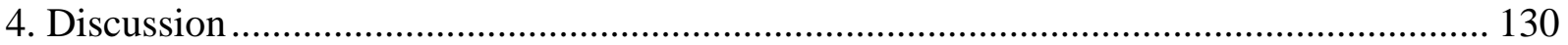

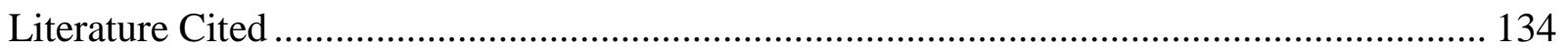




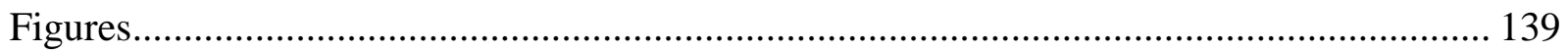

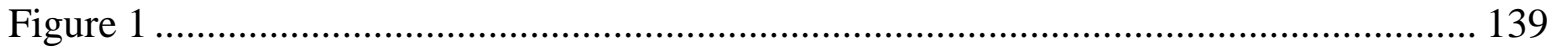

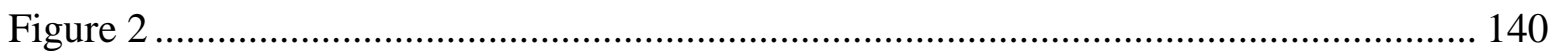

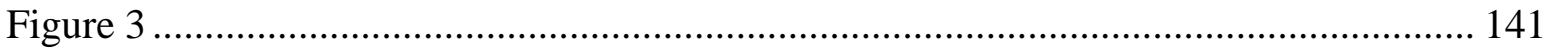

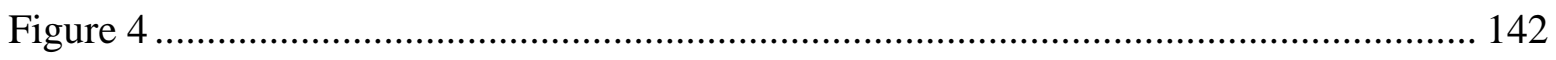

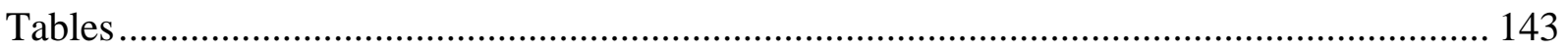

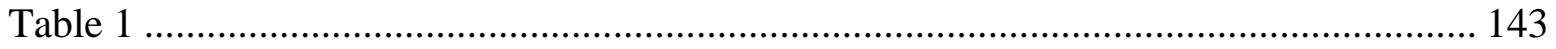

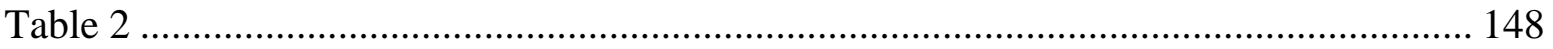

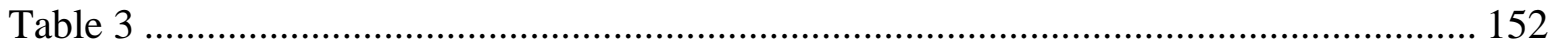

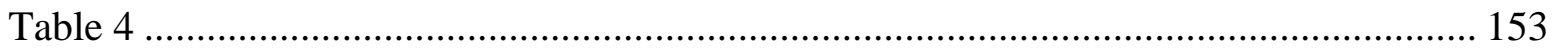

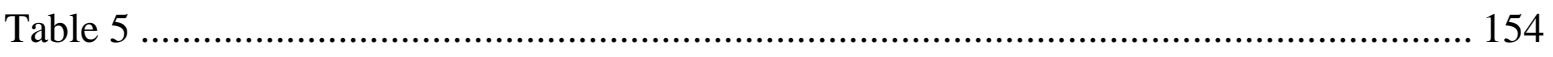

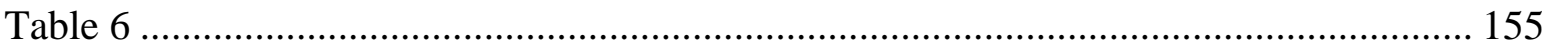

Chapter Five. Evaluation of possible interference as reported by the yeast strain Saccharomyces

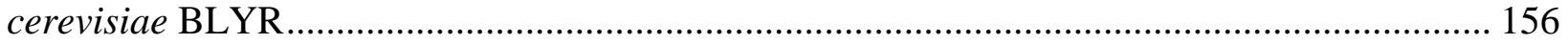

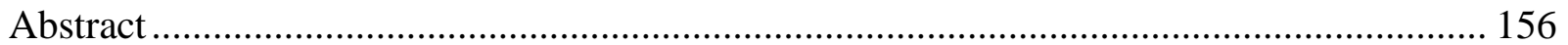

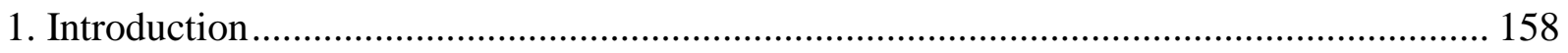

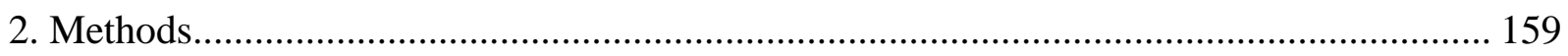

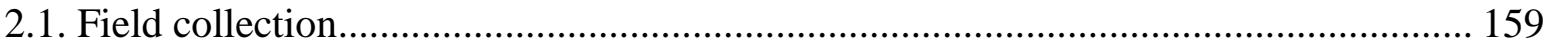

2.2. Laboratory preparation and extraction.................................................................. 160

2.3. Determination of toxicity, interference, and viability................................................ 162

2.4. Statistical Analysis .............................................................................................. 163

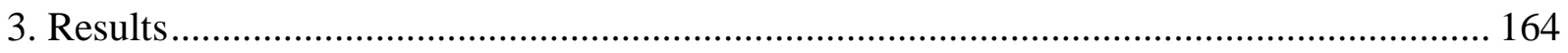

3.1. Viability and interference among Solvent, E2, and water samples ........................... 164

3.2. Environmental Samples …………….................................................................... 165

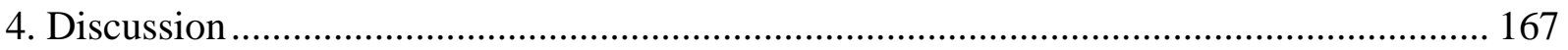

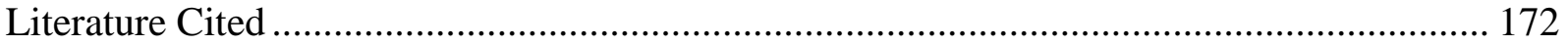

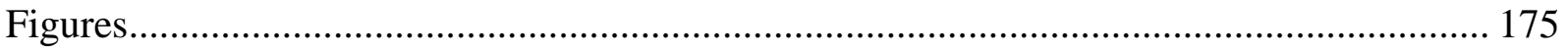

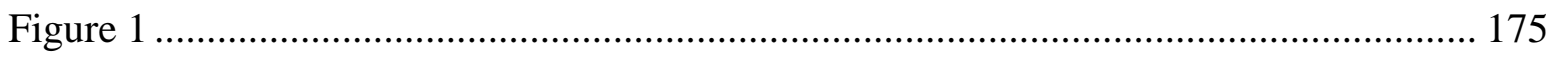

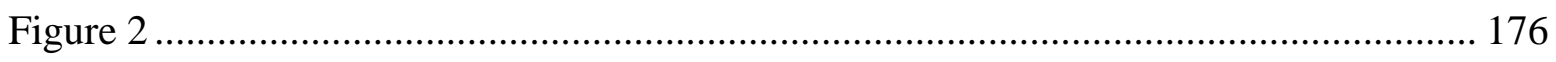

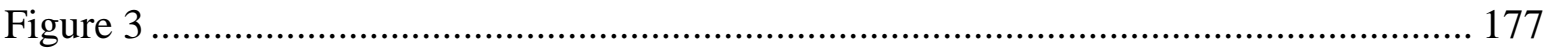

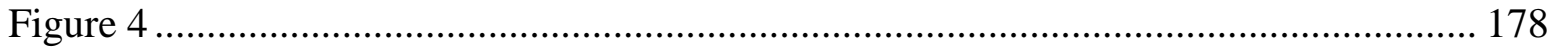

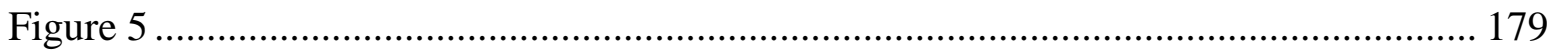

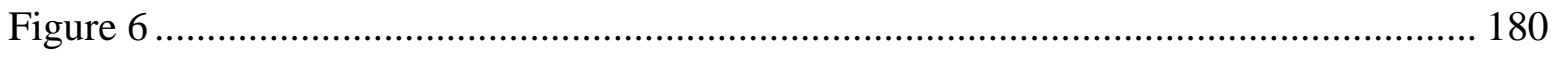




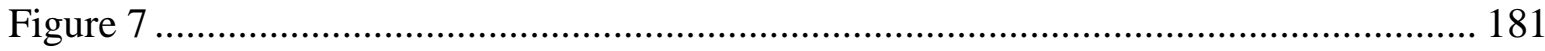

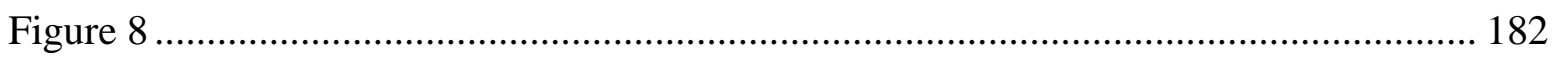

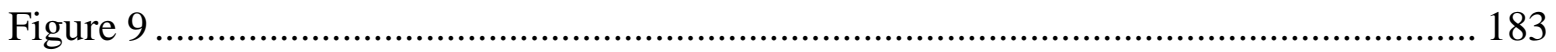

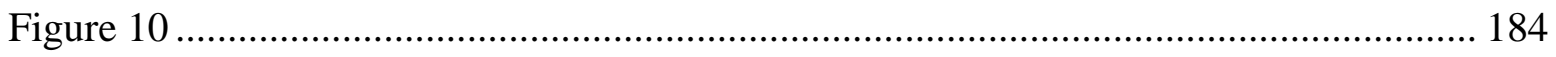

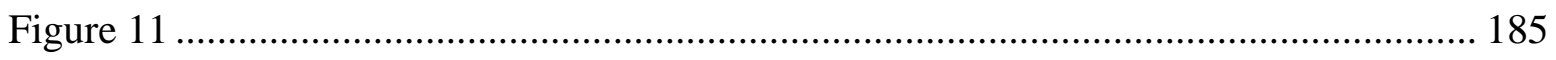

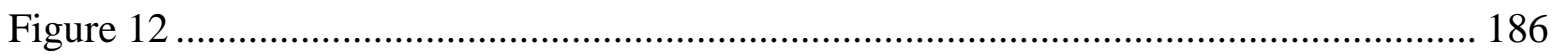

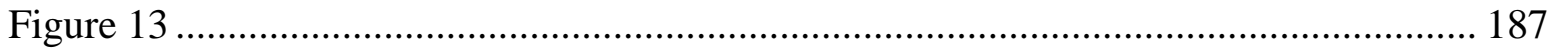

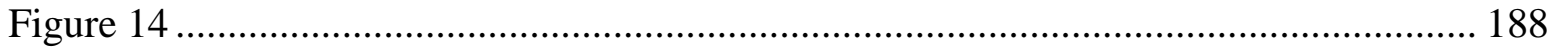

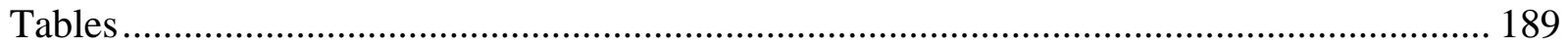

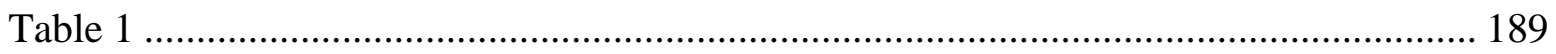

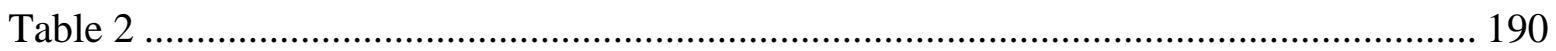

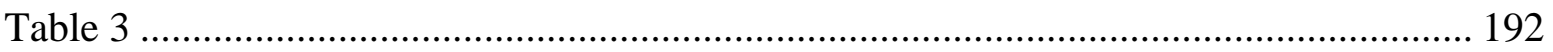

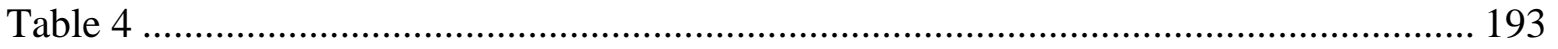

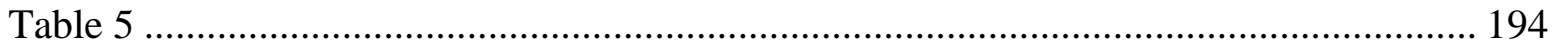

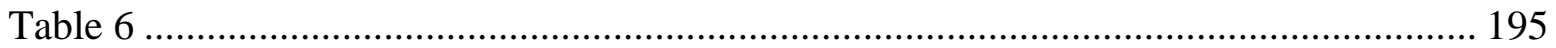




\section{Chapter One. Introduction and Literature Review}

\section{Microcystins in the aquatic environment and fish tissue}

Cyanobacteria are found throughout marine, freshwater, and terrestrial habitats. Some genera of cyanobacteria produce chemical toxins (cyanotoxins) that have been implicated in human and animal illness and death (Codd et al. 2005; Lopez et al. 2008). Toxins may also be produced by eukaryotic taxa (Landsberg 2002). The generic term for these compounds produced by both prokaryotic and eukaryotic organisms is algal toxins. Algal toxins can be sorted according to their primary effects which include neurotoxins, hepatotoxins, cytotoxins and irritants (Sivonen 2009). A variety of taxa have been identified that produce these toxins (Carmichael 1992b; Carmichael 1997; Dittmann and Wiegand 2006; Leflaive and Ten-Hage 2007). Under the current climate change projections, there is a growing global concern over the increased distribution and frequency of harmful algal blooms (Paerl and Huisman 2009).

Hepatotoxins are a family of cyanotoxins that are characterized by their toxic effects on hepatic tissue originating from various cyanobacteria taxa. The hepatotoxin microcystin (MC) is likely the most prevalent cyanotoxin in the environment comprising up to $1 \%$ dry weight of the total cyanobacteria biomass (Blaha et al. 2009; Pavagadhi and Balasubramanian 2013). Microcystin is a cyclic heptapeptide with over 80 known structural variants (Welker and von Dohren 2006). Microcystins contain 7 distinct regions with the aromatic $\beta$-amino acid side chain 3-amino-9-methoxy-2,6,8-trimethyl-10-phenyldeca-4,6-dienoic acid (ADDA) being highly conserved among all 89 known variants at position 5 (Carmichael 1997). The ADDA side chain facilitates transport into hepatic tissue (Campas and Marty 2007). This likely occurs via organic anion transporting peptides (Sierlslawska 2010). Microcystins impair fishes as a potent inhibitor of serine/threonine-specific protein phosphatases 1 and 2A (PP1 and PP2A, respectively; 
Runnegar et al. (1995)). Research with the MC structural variant, MCLR (containing the amino acids L-leucine and L-arginine at the variable positions 2 and 4, respectively) found that the inhibition of the PP1 and PP2A resulting from exposure was similar to the known PP1 and PP2A inhibitor and tumor promoter effects of okadaic acid suggesting that MCLR toxin may also act as a tumor promoter similar to the okadaic acid pathway (Carmichael 1992a; Carmichael 1997;

Nishiwaki-Matsushima et al. 1992). The specific inhibition of PP1 and PP2A by MCLR has been refined to specifically describe the inhibition of the catalytic subunits of PP1 and PP2A, as well as the ATP-synthase beta-subunit (Mikhailov et al. 2003). Inhibition is mediated by the ADDA side chain and the glutamyl carboxyl located at positions 5 and 6 , respectively. Covalent linkage of the thiol group of the cyctine-273 or -266 (for PP1 and PP2A, respectively) is bound with the $\alpha, \beta$-unsaturated carbonyl of the methyldroalanine (Mdha) group located at position 7 (Dawson 1998).

Additional effects (generally in the liver) have been observed resulting from exposure to MC toxin. For example, disruption of PP1 is believed to cause a disruption in intracellular glucose levels (Dawson 1998). When PP1 is in an inactive state, phosphorylase a remains tightly bound in an active, phosphorylated state and thus drives the conversion of glycogen to glucose (Goldberg et al. 1995). In a normal cell, under the influence of insulin, PP1 activates and phosphorylase a is deactivated into phosphorylase $\mathrm{b}$ which terminates the production of glucose. Microcystins bind PP1 in an inactive state which antagonizes the feedback from insulin. Over time, this will result in the loss of intracellular glycogen stores and may cause a downstream cascade to compensate for the increased levels of glucose. A second effect of MC toxin involves the protein actin (Ghosh et al. 1995). Specifically, MC appears to reorganize $\alpha$-actinin and talin. This reorganization is believed to be responsible for the breakdown of microtubules and 
intermediate filaments. It is believed that this restructuring is responsible for the collapse of sinusoidal capillaries which results in hemorrhaging (Dittmann and Wiegand 2006).

Although much of the documented effects from MC exposure focuses on acute toxicity, there is other research suggesting that MC exposure may be genotoxic (reviewed by Zegura et al. (2011)). Although the authors describe minimal evidence of genotoxicity of bacterial cells, they provide a thorough review of genotoxicity in mammalian cell lines. Furthermore, they review a suite of genes associated with DNA repair, tumor suppression, and tumor promotion which are modulated by exposure to MC's. The specific mode-of-action for the observed genotoxicity of MCLR is still debated. A likely scenario is that damage results not from MC directly but rather by the downstream effects from inhibition of PP1 and PP2A (Dias et al. 2014). Specifically, they theorize that the breakdown of microtubules results in strand breakage.

Microcystins have widely variable presence in the environment. O'Neil et al. (2012) provide a thorough review of the status of cyanobacterial blooms specifically from those genera which produce cyanotoxins. They describe in detail the difficulties in attributing blooms to water quality metrics such as eutrophication because the ability to either fix nitrogen or readily uptake phosphorous $(\mathrm{P})$ is variable among species. This can be confounded by rapid changes in species composition resulting from a high flow event. Among MC-producing cyanobacteria, the shift in species richness can be tracked via the variants observed as presented in Pawlik-Skowrońska et al. (2013). They observed an inverse correlation with total $\mathrm{P}$ in the water column and total intracellular MC among cyanobacteria. They also observed a slight shift away from the variants $-\mathrm{LA},-\mathrm{LY}$, and $-\mathrm{LF}$ to variant $-\mathrm{LR}$ which they believe was associated with an increased abundance of Microcystis spp. in the water column. Along with variability associated with species richness and nutrient availability, MC concentrations in the water column have been 
shown to fluctuate seasonally (Billam et al. 2006). They observed a reduction in total MC's in the warmer months with elevated concentrations in the cooler months. The authors suggest that the conditions in the warmer months were above the thermal threshold for the likely MCproducing cyanobacteria present in their system (Microcystis spp).

Much of the environmental research on MC's has focused on pelagic-oriented genera (Anabaena, Microcystis, Aphanizomenon, etc.). However, the presence of MC toxins in benthic cyanobacterial mats has also been documented and introduced as a potential health risk to pets and livestock (Codd et al. 1992; Mez et al. 1996; Mez et al. 1997). The genera identified were Oscillatoria, Phormidium, Tolypothrix and Stigonema. Mez et al. (1997) were able to detect protein phosphatase inhibition believed to be associated with MC in all 4 of these genera in Switzerland. However, only the species $O$. limosa and $P$. konstantinosum were able to cause mortalities via intraperitoneal injection (IP) in mice challenges. P. autumnale was not toxic to mice nor induced protein phosphatase inhibition but did have detectable concentrations of MC. Mohamed et al. (2006) identified a suite of benthic cyanobacterial species in Egyptian irrigation canals, of which 5 species produced MC as detected by an enzyme-linked immunosorbent assay (ELISA; Anabaena subcylindrica, Anabaena variables, Nostoc spongiaeforme, Plectonema boryanum, $P$. corium). Izaguirre et al. (2007) detected positive MC samples from southern California reservoirs. The isolates investigated were similar to the genera Oscillatoria, Lyngbya, and Phormidium. Although they did not make any final determination on the exact taxonomy, they did add to the phylogenetic tree of benthic-oriented MC-producing cyanobacteria. In New Zealand, MC variants were identified as likely responsible for dog deaths (Wood et al. 2010). The species implicated were morphologically similar to Phormidium but genetically similar to Planktothrix spp. Overall, benthic-oriented cyanobacteria have been shown to contribute 
significantly to the total MC load of aquatic systems and should be of interest to resource managers.

The presence and effects of MC's are well documented in the aquatic food web. FerraoFilho Ada and Kozlowsky-Suzuki (2011) provide a review of the presence of MC's among functional feeding groups of aquatic organisms. They provide a review of invertebrates (55 studies grouped by crustaceans, bivalves, gastropods, and zooplankton), as well as fish ( 28 studies grouped by carnivores, herbivores, omnivores, and planktivores). Overall, the zooplankton and planktivorous groups had the highest MC concentrations while crustaceans and carnivores had the lowest; however the data varied greatly among the representative groupings. Within fish, MC has been shown to accumulate in a variety of tissues such as the liver, intestine, kidney, etc. (e.g. Mohamed et al. 2003). In general, liver and kidneys had the most consistent MC concentrations across study sites while muscle tissue had the lowest in the omnivorous planktivore Oreochromis niloticus. Microcystin concentrations in the gut were variable across their sites. This would likely suggest that liver and kidneys are a more informative tissue of MC exposure while the intestine may help identify source (water vs. diet). Xie et al. (2005) provide a comprehensive analysis across multiple tissues in various fish species in China. They analyzed fish according to their functional feeding group (phytoplanktivorous, herbivorous, omnivorous, and carnivorous). Overall, carnivorous species had the highest MC concentrations in the liver and muscle. There was low reporting of MC in the blood and inconsistent data in the kidney. They observed high MC concentrations in the intestine of the phytoplanktivorous species similar to Mohamed et al. (2003). Interestingly, they also reported MC in the bile across taxa which were believed to be the first field study to report those results. Lei et al. (2008) evaluated the temporal distribution of MC in Carassius aurutus after IP injection. After one hour, they 
detected MC in all ten tissues (heart, spleen, gill, gonad, liver, brain, gallbladder, kidney, intestine, and muscle) with the highest concentrations reported in the heart, liver, and kidney. The brain, liver, gallbladder, and kidney all reported relatively higher concentrations of MC after 48 hours with the concentrations in the kidney increasing. This is likely the result from the detoxification of the toxin through the organs. Finally, Chen et al. (2009) quantified MC across tissues (intestinal contents, intestinal wall, liver, muscle, and gonad) and across aquatic species including periphyton (scum), four species of fish (Hypophthalmichthys molitrix (phytoplanktivorous), Cyprinus carpio (benthivorous), the C. aurutus (omnivorous), and the Culter ilishaeformis (carnivorous)), a turtle (Pelodiscus sinensis), a piscivorous heron (Nycticorax nycticoraxs), and a duck (Anas platyrhynchos). Similar to earlier research, they observed MC in most tissues with the highest concentrations in the intestinal contents and walls of the phytoplanktivorous Hypophthalmichthys molitrix. In general, the liver and muscle reported the most consistent MC concentrations across taxa with the gonad yielding variable concentrations. Based on the literature, the liver is the most likely organ to determine MC exposure across taxa and across functional feeding groups.

\section{Cyanobacterial Toxins Research Objectives}

Cyanobacterial blooms (specifically Microcystis aeruginosa) have been reported in the lower Potomac River in 1983 (Krogmann et al. 1986). They also provide a summary of additional blooms of cyanobacteria reported as early as 1930. The specific cause of these blooms is unclear; however it is believed to be partially driven by low water years (Krogmann et al. 1986). The evaluation of cyanotoxins, specifically the molecular effects observed within fish tissue from individuals collected within the Potomac River drainage may yield insight as to the overall health of both fish populations and the accompanying ecosystem. Our research objective 
is to quantify the abundance and distribution of MC's in the water column and benthos, as well as the bioaccumulation in hepatic tissues from fishes within the upper and middle Potomac River watershed.

\section{Evaluation of transcript abundance and possible association with total microcystins}

Much of the transcriptional MC research involves either the indirect effects from its metabolic detoxification or the downstream effects of unregulated phosphorylation. For example, Pflugmacher et al. (1998) focused on the effects of glutathione (GSH) and its conjugation enzyme glutathione-S-transferase (GST) which is believed to be the first step in MC detoxification. The antioxidant GSH is well documented as an oxidizer of compounds (Jones et al. 1978). However, this oxidization can lead to damage termed oxidative stress. Bouaicha and Maatouk (2004) evaluated rat hepatocytes for the effects of oxidative stress resulting from exposure to MCLR. Glutathione increased significantly 3 hours post exposure, however, it was not different than the control 24 and 48 hours post exposure. This was mirrored by the increase in reactive oxygen species (ROS) 0-60 minutes post-exposure. These data suggest a sharp increase in oxidative stress resulting from exposure to MCLR as GSH is a powerful antioxidant. Jayaraj et al. (2006) showed a decrease in GSH over time resulting from exposure to $38.31 \mu \mathrm{g} / \mathrm{kg}$ and $76.62 \mu \mathrm{g} / \mathrm{kg}$ MCLR. This was theorized to result from an exhaustion of stores of intracellular GSH. A similar decrease in the enzymes glutathione peroxidase (GPX) and superoxide dismutase (SOD) was observed and associated with oxidative stress. They did observe a timedependent increase in the genes that encode heat shock protein-70 (HSP70) and glutathione reductase (GR) at the high dose which would correspond with a response to oxidative stress. Microcystin-LR has also been shown to affect genes associated with signaling, metabolism, and apoptosis. Clark et al. (2007) examined a microarray on a suite of genes in mice livers associated 
with a variety of cellular activities. Real-time PCR results verified an upregulation of the genes cyst B, gss, gstm $3, n q o 1$, and jun following chronic exposure (IP) to $40 \mu \mathrm{g} / \mathrm{kg}$ body weight MCLR. Using a similar study design, Clark et al. (2008) exposed p53 deficient mice to the same concentration of MCLR. Analysis of similar genes showed a similar upregulation of the abovementioned genes; however most genes had a much higher fold-increase among the p53 deficient mice. This would suggest that p53 is an important modulator of MCLR within the liver. Interestingly, they also observed an upregulation of the gene that encodes the protein $\mathrm{p} 21$ (a cyclin-dependant kinase inhibitor). The protein p21 is generally assumed to be under the control of $\mathrm{p} 53$. The increase in the mutant mice would suggest that $\mathrm{p} 21$ can act independent of $\mathrm{p} 53$ following exposure to MCLR.

Microcystin-LR has also been evaluated on more primitive forms of life such as fishes in vivo. Liang et al. (2007) examined the expression of GST genes in the livers of three fish species; the silver carp (Hypophthalmichthys molitrix), grass carp (Ctenopharyngodon idellus), and Nile tilapia (Oreochromis nilotica). Specifically, they examined both the $\alpha$ class GST gene which corresponds to the cystolic GST in mammals and a unique $\rho$ class GST gene. Interestingly, all three species had different responses following eight and 24 hours post-IP injection. Silver carp expressed a significant increase in both GST classes eight hours post-exposure. After 24 hours, the $\alpha$ class was still significantly elevated while the $\rho$ class was expressed below control levels. In the grass carp, the $\alpha$ class expressed a significant reduction at both eight and 24 hours postinjection while there was no change in the $\rho$ class GST. The $\alpha$ class GST in Nile tilapia significantly decreased 8 hours post-injection, then significantly increased 24 hours postinjection. The $\rho$ class GST changed expression in the same trend as the silver carp. The authors postulate that the differential species-level response to detoxification of MCLR within tissue 
among these species may result from evolutionary tolerance to MC exposure. He et al. (2010) evaluated these three species for the expression of HSP70 in the liver. The chaperonin HSP70 was chosen as the authors were interested in evaluating the possible mechanisms present within each species to protect against oxidative stress which would result (for example) from exposure to MCLR. Each individual received a $50 \mu \mathrm{g} / \mathrm{kg}$ IP injection of MCLR. While both the grass carp and Nile tilapia both showed an increase in HSP70 expression 8 hours post-exposure, only the Nile tilapia was significant at the $\alpha=0.05$ level. They observed no change in the silver carp. This may suggest a genus-, if not species-level mechanism to metabolize the toxic effects of MCLR. Similar to Liang et al. (2007), the authors postulate an evolutionary link to MC tolerance among these species.

Microcystin-LR has been shown to interfere with the expression genes associated with exposure to endocrine disrupting compounds (Sychrová et al. 2012). Specifically, low doses on MCLR interferes with the gene that encodes the enzyme luciferase in the mammalian MELN cell line (Oziol and Bouaicha 2010). Following exposure, the luciferase gene was significantly upregulated. The authors suggest that this disruption results from the interference to the estrogen receptor by MCLR. Rogers et al. (2011) observed a similar upregulation in the gene that encodes vitellogenin (vtg, vtg1, vtg2, and $v t g 3$ ) in zebrafish (Danio rerio). Larvae were exposed 72 hours post fertilization to $100 \mu \mathrm{g} / \mathrm{L}$ and $1000 \mu \mathrm{g} / \mathrm{L}$ MCLR, as well as lyophilized Microcystis aeruginosa cells. Interestingly, the observed upregulation was only reported in individuals exposed to M. aeruginosa and not those exposed to MCLR. Marie et al. (2012) conducted a similar experiment on medaka (Oryzias lapites). Individuals were exposed (oral gavage) to an extract of the cyanobacteria Planktothrix agardhii which contained 2.5 $\mu \mathrm{g}$ of MCLR. Using a microarray, 15 genes that encode proteins associated with oxidative stress were identified and 
differentially expressed among challenged fish. The gene that encodes vitellogenin was also upregulated among the challenged fish. Although there are likely a variety of compounds capable of influencing the genes that encode vitellogenin, this would suggest that MCLR may act as an endocrine disruptor. The effects on MCLR was elucidated in vivo by Zhao et al. (2015). The authors observed a positive correlation in a suite of genes associated with the hypothalamicpituitary-gonadal axis, ovarian maturation, and vitellogenin. This correlation generally broke down at their high dose (likely due to cytotoxicity). Wei et al. (2008) identified genes associated with mitogen-activated protein kinases (MAPK) and immune pathways in zebrafish exposed to purified MCLR. Although the specific mechanism is not clear, MCLR or the cyanobacteria which metabolize them should be considered contributors to endocrine disruption in aquatic systems.

\section{Influence of microcystin on the transcriptional leukocyte response of fishes to a bacterial insult ex vivo}

Chronic mortality of fish has been reported in a variety of species within the Chesapeake Bay drainage. Some of these fish kill events have been linked to specific pathogens. Examples include Aphanomyces invadans which afflicts Atlantic menhaden (Brevoortia tyrannus; Blazer et al. (2002)) and Mycobacterium spp. which afflicts striped bass (Morone saxatilis; Gauthier et al. (2008)). There are, however reported fish kill events which have no clear correlation to any one specific pathogen or contaminant. An example of such events is reported by Blazer et al. (2010). Although a variety of pathogens were identified (such as trematodes, myxozoans, Aeromonas hydrophila, Aeromonas salmonicida, Flavobacterium columnare, and largemouth bass virus), no clear correlation to any fish kill event could be derived. This is likely due to a variety of contributing factors which lead to diminished overall fish health. 
Microcystin toxins have been reported to affect immunological endpoints in fishes (Palíková et al. 1998). The researchers highlight the differential response among similar species (common carp (Cyprinus carpio) and silver carp (Hypophthalmichthys molitrix)). Consistent among both species was the inverse correlation among total leukocytes with MC concentration. Among silver carp, there was an inverse correlation among phagocytic activity and MC concentration. The authors more closely evaluated individual cell types which yielded variable results. Overall, they concluded a general immunosuppression by MCLR. These initial findings of immunomodulation were expounded upon by Rymuszka et al. (2010) in common carp. They noted an increase in respiratory burst activity at low doses $(0.01 \mu \mathrm{g} / \mathrm{mL})$ but a decrease at higher concentrations of MCLR (>0.5 $\mu \mathrm{g} / \mathrm{mL})$. They theorize this was due to the specific cytotoxicity among granulocytes at these concentrations. Lymphocytes showed a decreased proliferative response to lipopolysaccharide (LPS) at higher concentrations ( $>0.5 \mu \mathrm{g} / \mathrm{mL}$ ); however there was no affect from concanavalin A (ConA). The authors explain this as ConA is known to stimulate T-cells (among other cell types) while LPS stimulates B-cells (among other cell types). This is important given the function of B-cells (in part) producing immunoglobulins (Ig; specifically in teleost fishes $\operatorname{IgM}$, $\operatorname{IgD}$, $\operatorname{Ig} T$, and the light chain $\operatorname{Ig} \lambda$, $\operatorname{Ig} \kappa, \operatorname{Ig} \sigma$, and $\operatorname{Ig} \sigma-2)$ as reviewed by Sunyer (2012) and Mashoof and Criscitiello (2016). The B cells are critical for antibody development as part of the adaptive humoral immunity.

Rymuszka and Adaszek (2012) reviewed a suite of genes in response to MC stimulation. Specifically, they quantified the pro-inflammatory genes interleukin-1 $\beta$ (IL-1 $\beta)$ and tumor necrosis factor- $\alpha$ (TNF- $\alpha$ ), as well as the anti-inflammatory genes interleukin-10 (IL-10) and transforming growth factor- $\beta$ (TGF- $\beta$ ) in common carp cultured leukocytes (isolated both from blood and anterior kidney). The authors observed a positive dose response among the two anti- 
inflammatory cytokines. There was a positive response among both pro-inflammatory cytokines at the low dose $(0.01 \mu \mathrm{g} / \mathrm{mL})$ and an inverse correlation at the high dose $(0.1 \mu / \mathrm{mL})$ of MCLR. Their results begin to shed light on the observed immunomodulation as previously mentioned. They document an upregulation of certain pro-inflammatory cytokines at low doses of MC and a nominal upregulation of anti-inflammatory cytokines at these concentrations. However at higher concentrations the anti-inflammatory transcripts are significantly higher and may be overwhelming the pro-inflammatory cytokines. It should be noted that this was only at $10 \%$ of World Health Organization (WHO) guideline for MCLR in drinking water (1 $\mu \mathrm{g} / \mathrm{L} ;$ WHO 1998). Rymuszka and Adaszek (2013) followed up their earlier results in vitro and in vivo, again with common carp using aqueous exposure. Similar to previous studies, this study showed the cytotoxicity among phagocytic cells at higher concentrations of MCLR $(>0.5 \mu \mathrm{g} / \mathrm{mL})$. A major change in this study was that MCLR did not yield the same transcriptional results as the in vitro study. However when they used MC-producing cyanobacterial extract, they observed a dosedependent increase in both pro-inflammatory cytokines and the anti-inflammatory cytokine IL10. This elucidated the fact that not only the purified toxin but also cyanobacterial lysate can have immunomodulatory effects.

Chen et al. (2017) quantified endpoints of oxidative stress (the enzymes superoxide dismutase (SOD), catalase (CAT), and glutathione peroxidase (GPX)), as well as proinflammatory cytokines in common carp following IP injection. The specific transcriptional endpoints were the pro-inflammatory IL-1 $\beta$, TNF- $\alpha$, interferon type I (IFN-I), as well as the chaperonins HSP70, and heat shock protein 90 (HSP90). They observed an upregulation in all of the oxidative stress endpoints immediately following MCLR exposure. Most of these enzymes returned to pre-challenge levels by the end of their experiment. Similarly, both chaperonins were 
upregulated immediately following MCLR exposure but returned to baseline levels over time. All three pro-inflammatory cytokines were downregulated following exposure across MCLR treatments. Overall, the response of oxidative stress and chaperonin endpoints suggest detoxification and clearing of the toxin. What is quite interesting is the downregulation of the pro-inflammatory cytokines. The authors postulate that this response may occur to minimize an excessive response within the cell. An unintended downstream effect of this downregulation may be to dampen the immune response to a bacterial insult (specifically the toll-like receptor 2 (TLR2) signaling cascade (Rebl et al. 2010).

Li et al. (2009) quantified a broad swath of genes associated with immunoregulation in zebrafish (Danio rerio) larvae under an aqueous challenge with MCLR. Among their analysis were 6 genes associated with T and B cell development (recombination activation gene-1 and -2 (RAG1 and RAG2), Ikaros, erythroid transcription factor (GATA1), lymphocyte-specific protein tyrosine kinase (Lck), and T-cell receptor $\alpha(\mathrm{TCR} \alpha)$. They also quantified 4 heat shock proteins (HSP27, HSP60, HSP70, and HSP90) as they are commonly associated with exposure to antigens. They observed reduced transcript abundance of both RAG genes during the first 48 hours followed by an increased abundance up to 168 hours. There were variable responses among Ikaros, GATA1, Lck, and TCR $\alpha$. Most notable was a significant increase in Lck abundance after 96 hours and a nearly consistent increased abundance of Ikaros and GATA1. The gene TCR $\alpha$ was only significantly upregulated in the high dose group $(800 \mu \mathrm{g} / \mathrm{L})$. They provide a thorough review of the function of each of these genes which, taken as a whole provide a more detailed example of immunomodulation by MCLR. For example, the upregulation of the non-chaperonin genes could lead to proliferation of T- and B-cells. 
$\underline{\text { Smallmouth Bass Hepatic and Leukocyte Transcriptional Abundance Research Objectives }}$

The effects of MCLR on hepatocytes are well documented. However, to our knowledge there are no data on the molecular effects of MCLR on SMB. Our research objective is to evaluate SMB hepatocytes stimulated with MCLR ex vivo. To our knowledge, there are no data characterizing the leukocyte transcriptome of SMB. We are unaware of any data describing the transcriptional response of SMB leukocytes to MC toxins. Thus, our specific research objective is to investigate the effects of MCLR toxin on the transcriptional response of leukocytes to the immunostimulant peptidoglycan.

\section{Associations among estrogenic activity, select chemical compounds and microcystin toxins}

A variety of endocrine disrupting compounds (EDC's) have been identified in surface waters throughout the United States (Kolpin et al. 2002; Snow et al. 2010). Of these compounds, a subset has been shown to act directly or indirectly as estrogenic compounds in living organisms. The exact sources of these compounds are diverse. Young et al. (2014) provided a landscape analysis of estrogenic activity within a large part of the upper Potomac River basin. They identified agricultural practices (confined animal feedlot operations), as well as urban impacts (wastewater inputs) as positively correlated to estrogenic endpoints. Campbell et al. (2006) provide a review of the transport of estrogenic EDC's through the environment. They reviewed the suite of biological assays which identify those effects in organisms. Blazer et al. (2012) and Iwanowicz et al. (2009) have used many of these techniques to quantify exposure to estrogenic compounds in the environment. Taken together, these studies highlight the complex distribution of estrogenic compounds in the environment and the difficulty in correlating biological effect to the presence of estrogenic activity across endpoints. 
A less understood source of estrogenic compounds is the contribution from photosynthetic organisms. Liu et al. (2010) reviewed a suite of phytoestrogens and their association with wastewater facilities. They determined that phytoestrogens were positively correlated to the excretion rates of human urea associated with wastewater facility inflow. Kang and Price (2009) quantified phytoestrogenic compounds associated with wastewater facilities and streams. They identified a suite of phytoestrogens present in wastewater inflow but very little in the outflow. They also quantified a suite of phytoestrogens in the environment. Specifically, the compounds present (daidzein, enterolactone, enterodiol, genistein and formononetin) are associated with agricultural systems. These results are supported by Kolpin et al. (2010). They quantified a variety of phytoestrogens (as well as mycotoxins and atrazine) in Iowa that were associated with agricultural systems. A thorough review of current phytoestrogen research is provided by Jarosova et al. (2015). They highlight the correlation of phytoestrogen presence to agricultural systems and wastewater treatment facilities (WWTP's). They also reported the data gaps associated with estrogenic potency, the effect on biological systems as compared to animal sterols, and the potential contribution from cyanobacteria as a possible source for phytoestrogens in the environment.

The purified secondary cyanobacterial metabolite MCLR has been shown to cause an increase in estrogenic activity in the MELN cell line. Oziol and Bouaicha (2010) reported a small increase in activity of the luciferase gene. This effect was shown to be estrogen receptormediated as it was inhibited via an estrogen receptor antagonist (although dose-dependency curves were likely skewed from the cytotoxicity of MCLR). They concluded that at low concentrations MCLR had an indirect relationship with the estrogen receptor. Along with purified MCLR, extracts from cyanobacteria and algal taxa have been found to contribute 
environmental estrogens in vitro. Štěpánková et al. (2011) reported detectable estrogenic equivalency from cyanobacterial extracts using the MVLN cell line from Planktothrix agardhii, Aphanizomenon gracile, and Microcystis aeruginosa. Sychrová et al. (2012) expanded upon this research and showed appreciable estrogenic potential in extracts from the cyanobacteria Aphanizomenon gracile and Microcystis aeruginosa and the algae Cylindrospermopsis raciborskii and Chlorella kessleri. They also showed that extracts from the cyanobacterial species Aphanizomenon flos-aquae and the algae Scenedesmus quadricauda were found to be estrogen receptor antagonists. Based on this research, it is important to consider the contribution of phytoestrogens when evaluating the total estrogenicity of surface waters.

The source of phytoestrogens in the environment is likely correlated to land use practices. Many of these compounds are present either directly or as a metabolite from legumes (Franke et al. 1994). They quantified the phytoestrogens coumestrol, biochanin A, daidzein, formononetin, and genistein in a variety of legumes using high-performance liquid chromatography. Kuhnle et al. (2009) further described additional non-legume sources of phytoestrogens sorted by isoflavones (biochanin A, daidzein, formononetin, genistein and glycitein), lignans (matairesinol and secoisolariciresinol), as well as coumestrol. Jarosova et al. (2015) provide a review of the distribution and concentrations of known phytoestrogens in the literature. Along with providing a comprehensive list of compounds and sources, they also include the relative estrogenic equivalency (cEEQ) which they define as the concentration multiplied by the relative potency as compared to $17 \beta$-estradiol (E2) specific to the assay conducted. Although the relative potencies of each compound is generally $>10^{2}$ less than that of E2, the ubiquity of sources is concerning. Although many of the plants which produce these compounds may appear in the wild, agribusiness can increase their occurrence on the landscape by encouraging the growth of plants 
which contain higher concentrations of phytoestrogens (e.g. legumes). However the presence of phytoestrogens is not strictly confined to agricultural run-off. For example, equol is a metabolite of intestinal bacteria derived from the breakdown of the soy isoflavones daidzin and daidzein (Setchell and Clerici 2010). It is released in the waste of animals containing these bacteria and can occur in humans, livestock, and in the wild. Thus, phytoestrogen occurrence in the environment may be linked both to point- and non-point source pollution.

Phytoestrogen exposure has been correlated to biological markers of endocrine disruption. Bagheri et al. (2014) observed an increase in plasma E2 as a result of a long-term feed study with goldfish (Carassius auratus) supplemented with genistein and daidzein. Kiparissis et al. (2003) observed an increase in testicular oocytes (TO) when they exposed Oryzias latipes to the isoflavones equol and genestein. They observed TO occurrence rates of $12 \%$ at $1 \mathrm{~g} / \mathrm{L}$ genestein and $10 \%$ at $0.4 \mu \mathrm{g} / \mathrm{L}$ equol. They also reported that equol caused a dosedependent impairment of spermatogenesis. Wang et al. (2016) also observed a higher occurrence of TO in O. latipes as a result of exposure to equol ( $35 \%$ at $145.7 \mathrm{ng} / \mathrm{L})$. They also observed an inverse dose-response in 11-ketotestosterone suggesting that equol may be antiandrogenic. Phytoestrogens have been shown to induce changes in transcript abundance. Cleveland and Manor (2015) exposed rainbow trout (Oncorhynchus mykiss) IP to genestein and daidzein and compared the transcriptional response to E2 and the control. They observed a significant upregulation of the gene which encodes the egg yolk precursor protein vitellogenin among both genestein and daidzein. They also observed mixed effects among a suite of other genes within the liver which (among other functions) are associated with endocrine disruption and cellular regulation. 


\section{Environmental Estrogens Research Objectives}

The presence of biologically relevant estrogenic compounds is becoming better documented. However, the change in these estrogenicity data over time (monthly and yearly) is less understood. My research objective is to monitor the distribution of estrogenic compounds in the middle and upper Potomac River watershed among various land cover/land use areas. This estrogenic signal can be compared to the occurrence of both steroidal and phytoestrogens. This signal can also be compared to both physical and nutrient parameters.

Evaluation of possible interference as reported by the yeast strain Saccharomyces cerevisiae BLYR

Biological assays (bioassays) are designed to quantify an effect in the context of a living organism. Estrogenic endocrine disrupting compounds (EEDCs) are a group of compounds which have been shown to modulate estrogen receptor-mediated pathways in aquatic organisms (Campbell et al. 2006). Many of these compounds (which include both steroidal and nonsteroidal chemicals) have been correlated to deleterious biological effects in fishes (Segner et al. 2013; Senthilkumaran 2015). Routledge and Sumpter (1996) described a yeast (Saccharomyces cerevisiae) bioassay which incorporates human estrogen receptor (hER) into the yeast genome, as well as the reporter gene $L a c-Z$. This allows for the identification of compounds which activate this specific pathway and is termed the yeast estrogen screen assay (YES). Sanseverino et al. (2005) further developed the strain S. cerevisiae and instead of the colorimetric Lac-z reporter, they incorporate the bioluminescent $\operatorname{lux} A / B$ reporter. This strain is termed bioluminescent yeast estrogen screen (BLYES). The new strain S. cerevisiae BLYES yielded a similar detection range of $17 \beta$-estradiol standards; however shortened the duration of the assay 
from 72 hours to 6 hours. This strain was used to determine the estrogenicity of samples in Chapter Four.

An important component of bioassays is the determination of cellular viability both before and after a challenge experiment. This ensures that the observed effect is not due to cell death (termed toxicity) but from the experimental agent. The strain S. cerevisiae BLYR(a) was first published by Eldridge et al. (2007) and was designed to constitutively express the luxA/B bioluminescent reporter. This was done to report cytotoxicity among (in this example) potentially androgenic compounds (incorporating human androgen receptor instead of hER and termed the bioluminescent yeast androgen screen (BLYAS)). The authors identified toxicity by a reduction in the bioluminescent reporter as compared to a control. Sanseverino et al. (2009) analyzed a comprehensive suite of compounds and quantified the estrogenic and androgenic potential using the BLYES and BLYAS assays as well as the toxicity as reported by BLYR.

\section{Cell Viability Research Objective}

To our knowledge, there are no data reporting the environmental trends in water or periphyton with regards to strain S. cerevisiae BLYR. Interference is defined as a significant deviation from the control luminescence. The specific objective of this study was to determine whether the interference (specifically the lower output luminescence) determined by the BLYR assay constitutes dead cells as reported by flow cytometry. The second objective was to quantify the variability in strain BLYR among environmental samples. These results were compared to both the microcystin data as reported in Chapter Two and estrogenicity data reported in Chapter Four. 


\section{Literature Cited}

Bagheri, T., M. R. Imanpoor, and V. Jafari. 2014. Effects of diets containing genistein and diadzein in a long-term study on sex steroid dynamics of goldfish (Carassius auratus). Toxicology and Industrial Health 30(2):132-140.

Billam, M., and coauthors. 2006. Seasonal variations in the concentration of microcystin-LR in two lakes in western Texas, USA. Environmental Toxicology and Chemistry 25(2):349355.

Blaha, L., P. Babica, and B. Marsalek. 2009. Toxins produced in cyanobacterial water blooms toxicity and risks. Interdiscipinary Toxicology 2(2):36-41.

Blazer, V. S., and coauthors. 2012. Reproductive endocrine disruption in smallmouth bass (Micropterus dolomieu) in the Potomac River basin: spatial and temporal comparisons of biological effects. Environmental Monitoring and Assessment 184(7):4309-34.

Blazer, V. S., and coauthors. 2010. Mortality of centrarchid fishes in the Potomac drainage: survey results and overview of potential contributing factors. Journal of Aquatic Animal Health 22(3):190-218.

Blazer, V. S., and coauthors. 2002. Aphanomyces invadansin Atlantic Menhaden along the East Coast of the United States. Journal of Aquatic Animal Health 14(1):1-10.

Bouaicha, N., and I. Maatouk. 2004. Microcystin-LR and nodularin induce intracellular glutathione alteration, reactive oxygen species production and lipid peroxidation in primary cultured rat hepatocytes. Toxicological Letters 148(1-2):53-63.

Campas, M., and J. L. Marty. 2007. Highly sensitive amperometric immunosensors for microcystin detection in algae. Biosensors and Bioelectronics 22(6):1034-40.

Campbell, C. G., and coauthors. 2006. Biologically directed environmental monitoring, fate, and transport of estrogenic endocrine disrupting compounds in water: A review. Chemosphere 65(8):1265-80.

Carmichael, W. W. 1992a. Cyanobacteria secondary metabolites--the cyanotoxins. The Journal of Applied Bacteriology 72(6):445-459.

Carmichael, W. W. 1992b. Cyanobacteria secondary metabolites- the cyanotoxins. Journal of Applied Bacteriology 72:445-459.

Carmichael, W. W. 1997. The cyanotoxins. Advances in Botanical Research 27:211-256.

Chen, J., D. Zhang, P. Xie, Q. Wang, and Z. Ma. 2009. Simultaneous determination of microcystin contaminations in various vertebrates (fish, turtle, duck and water bird) from a large eutrophic Chinese lake, Lake Taihu, with toxic Microcystis blooms. Science of the Total Environment 407(10):3317-22.

Chen, X. M., and coauthors. 2017. Modulatory role of L-carnitine against microcystin-LRinduced immunotoxicity and oxidative stress in common carp. Fish Physiology and Biochemistry 
Ciparis, S., L. R. Iwanowicz, and J. R. Voshell. 2012. Effects of watershed densities of animal feeding operations on nutrient concentrations and estrogenic activity in agricultural streams. Science of the Total Environment 414:268-76.

Clark, S. P., M. A. Davis, T. P. Ryan, G. H. Searfoss, and S. B. Hooser. 2007. Hepatic gene expression changes in mice associated with prolonged sublethal microcystin exposure. Toxicologic Pathology 35(4):594-605.

Clark, S. P., T. P. Ryan, G. H. Searfoss, M. A. Davis, and S. B. Hooser. 2008. Chronic microcystin exposure induces hepatocyte proliferation with increased expression of mitotic and cyclin-associated genes in P53-deficient mice. Toxicologic Pathology 36(2):190-203.

Cleveland, B. M., and M. L. Manor. 2015. Effects of phytoestrogens on growth-related and lipogenic genes in rainbow trout (Oncorhynchus mykiss). Comparative Biochemistry and Physiology - Part C: Toxicology 170:28-37.

Codd, G. A., C. Edwards, K. A. Beattie, W. M. Barr, and G. J. Gunn. 1992. Fatal attraction to cyanobacteria? Nature 359:110-111.

Codd, G. A., L. F. Morrison, and J. S. Metcalf. 2005. Cyanobacterial toxins: risk management for health protection. Toxicology and Applied Pharmacology 203(3):264-72.

Dawson, R. M. 1998. The toxicology of microcystins. Toxicon 36(7):953-932.

Dias, E., and coauthors. 2014. Genotoxicity of microcystin-LR in in vitro and in vivo experimental models. BioMed Research International 2014:949521.

Dittmann, E., and C. Wiegand. 2006. Cyanobacterial toxins--occurrence, biosynthesis and impact on human affairs. Molecular Nutrition \& Food Research 50(1):7-17.

Eldridge, M. L., and coauthors. 2007. Saccharomyces cerevisiae BLYAS, a new bioluminescent bioreporter for detection of androgenic compounds. Applied and Environmental Microbiology 73(19):6012-8.

Ferrao-Filho Ada, S., and B. Kozlowsky-Suzuki. 2011. Cyanotoxins: bioaccumulation and effects on aquatic animals. Marine Drugs 9(12):2729-72.

Franke, A. A., L. J. Custer, C. M. Cerna, and K. K. Narala. 1994. Quantitation of Phytoestrogens in Legumes by HPLC. Journal of Agricultural and Food Chemistry 42(9):1905-1913.

Gauthier, D. T., and coauthors. 2008. Mycobacteriosis-associated mortality in wild striped bass (Morone saxatilis) from Chesapeake Bay, U.S.A. Ecological Applications 18(7):17181727.

Ghosh, S., S. Ali Khan, M. Wickstrom, and V. Beasley. 1995. Effects of microcystin-LR on actin and the actin-associated proteins alpha-actinin and talin in hepatocytes. Natural Toxins 3(6):405-414.

Gill, J. E., M. M. Jotz, S. G. Young, E. J. Modest, and S. K. Sengupta. 1975. 7-Aminoactinomycin D as a cytochemical probe. I. Spectral properties. Journal of Histochemistry \& Cytochemistry 23(11):793-799.

Goldberg, J., and coauthors. 1995. Three-dimensional structure of the catalytic subunit of protein serine/threonine phosphatase-1. Nature 376(31):745-753. 
He, S., and coauthors. 2010. Molecular characterization of heat shock protein 70 genes in the liver of three warm freshwater fishes with differential tolerance to microcystin-LR. Journal of Biochemical and Molecular Toxicology 24(5):293-302.

Iwanowicz, L. R., and coauthors. 2009. Reproductive health of bass in the Potomac, U.S.A., drainage: part 1. Exploring the effects of proximity to wastewater treatment plant discharge. Environmental Toxicology and Chemistry 28(5):1072-1073.

Iwanowicz, L. R., and coauthors. 2016. Evidence of estrogenic endocrine disruption in smallmouth and largemouth bass inhabiting Northeast U.S. national wildlife refuge waters: A reconnaissance study. Ecotoxicology and Environmental Safety 124:50-9.

Izaguirre, G., A. D. Jungblut, and B. A. Neilan. 2007. Benthic cyanobacteria (Oscillatoriaceae) that produce microcystin-LR, isolated from four reservoirs in southern California. Water Research 41(2):492-8.

Jarosova, B., J. Javurek, O. Adamovsky, and K. Hilscherova. 2015. Phytoestrogens and mycoestrogens in surface waters--Their sources, occurrence, and potential contribution to estrogenic activity. Environment International 81:26-44.

Jayaraj, R., T. Anand, and P. V. Rao. 2006. Activity and gene expression profile of certain antioxidant enzymes to microcystin-LR induced oxidative stress in mice. Toxicology 220(2-3):136-46.

Jones, D. P., H. Thor, B. Andersson, and S. Orrenius. 1978. Detoxification Reactions in Isolated Hepatocytes. Role of Glutathione Peroxidase, Catalase, and Formaldehyde Dehydrogenase in Reactions Relating to N-Demethylation by the Cytochrome P-450 System. The Journal of Biolocical Chemistry 253(17):6031-6037.

Kang, J., and W. E. Price. 2009. Occurrence of phytoestrogens in municipal wastewater and surface waters. Journal of Environmental Monitoring 11(8):1477-83.

Kiparissis, Y., G. C. Balch, T. L. Metcalfe, and C. D. Metcalfe. 2003. Effects of the Isoflavones Genistein and Equol on the Gonadal Development of Japanese Medaka (Oryzias latipes). Environmental Health Perspectives 111(9):1158-1163.

Kolpin, D. W., and coauthors. 2002. Pharmaceuticals, Hormones, and Other Organic Wastewater Contaminants in U.S. Streams, 1999-2000: A National Reconnaissance. Environmental Science and Technology 36(6):1202-1211.

Kolpin, D. W., and coauthors. 2010. Phytoestrogens and Mycotoxins in Iowa Streams: An Examination of Underinvestigated Compounds in Agricultural Basins. Journal of Environment Quality 39(6):2089.

Krogmann, D. W., R. Butalla, and J. Sprinkle. 1986. Blooms of Cyanobacteria on the Potomac River. Plant Physiology 80:667-671.

Kuhnle, G. G. C., C. Dell'Aquila, S. A. Runswick, and S. A. Bingham. 2009. Variability of phytoestrogen content in foods from different sources. Food Chemistry 113(4):11841187.

Landsberg, J. H. 2002. The Effects of Harmful Algal Blooms on Aquatic Organisms. Reviews in Fisheries Science 10(2):113-390. 
Leflaive, J. P., and L. Ten-Hage. 2007. Algal and cyanobacterial secondary metabolites in freshwaters: a comparison of allelopathic compounds and toxins. Freshwater Biology 52(2):199-214.

Lei, H., and coauthors. 2008. Distribution of toxins in various tissues of crucian carp intraperitoneally injected with hepatotoxic microcystins. Environmental Toxicology and Chemistry 27(5):1167-1174.

Li, Y., B. Sun, H. Wu, and P. Nie. 2009. Effects of pure microcystin-LR on the transcription of immune related genes and heat shock proteins in larval stage of zebrafish (Danio rerio). Aquaculture 289(1-2):154-160.

Liang, X.-F., G.-G. Li, S. He, and Y. Huang. 2007. Transcriptional responses of alpha- and rhoclass glutathione $\mathrm{S}$-transferase genes in the liver of three freshwater fishes intraperitoneally injected with microcystin-LR: relationship of inducible expression and tolerance. Journal of Biochemical and Molecular Toxicology 21(5):289-298.

Liu, Z. H., Y. Kanjo, and S. Mizutani. 2010. A review of phytoestrogens: their occurrence and fate in the environment. Water Research 44(2):567-577.

Lopez, C. B., E. B. Jewett, Q. Dortch, B. T. Walton, and H. K. Hudnell. 2008. Interagency Working Group on Harmful Algal Blooms, Hypoxia, and Human Health of the Joint Subcommittee on Ocean Science and Technology.

Marie, B., and coauthors. 2012. Effects of a toxic cyanobacterial bloom (Planktothrix agardhii) on fish: insights from histopathological and quantitative proteomic assessments following the oral exposure of medaka fish (Oryzias latipes). Aquatic Toxicology 114-115:39-48.

Mashoof, S., and M. Criscitiello. 2016. Fish Immunoglobulins. Biology 5(4):45.

Mez, K., and coauthors. 1997. Identification of a microcystin in benthic cyanobacteria linked to cattle deaths on alpine pastures in Switzerland. European Journal of Phycology 32(2):111-117.

Mez, K., K. Hanselmann, H. Naegeli, and H. R. Preisig. 1996. Protein phosphatase-inhibiting activity in cyanobacteria from alpine lakes in Switzerland. Phycologia 35(6S):133-139.

Mikhailov, A., A.-S. Härmälä-Braskén, J. Hellman, J. Meriluoto, and J. E. Eriksson. 2003. Identification of ATP-synthase as a novel intracellular target for microcystin-LR. Chemico-Biological Interactions 142(3):223-237.

Mohamed, Z. A., W. W. Carmichael, and A. A. Hussein. 2003. Estimation of microcystins in the freshwater fish Oreochromis niloticus in an Egyptian fish farm containing a Microcystis bloom. Environmental Toxicology 18(2):137-41.

Mohamed, Z. A., H. M. el-Sharouny, and W. S. Ali. 2006. Microcystin production in benthic mats of cyanobacteria in the Nile River and irrigation canals, Egypt. Toxicon 47(5):58490.

Nicoletti, I., G. Migliorati, M. C. Pagliacci, F. Grignani, and C. Riccardi. 1991. A rapid and simple method for measuring thymocyte apoptosis by propidium iodide staining and flow cytometry. Journal of Immunological Methods 139(2):271-279. 
Nishiwaki-Matsushima, R., and coauthors. 1992. Liver tumor promotion by the cyanobacterial cyclic peptide toxin microcystin-LR. Journal of Cancer Research and Clinical Oncology 118(6):420-424.

O’Neil, J. M., T. W. Davis, M. A. Burford, and C. J. Gobler. 2012. The rise of harmful cyanobacteria blooms: The potential roles of eutrophication and climate change. Harmful Algae 14:313-334.

Oziol, L., and N. Bouaicha. 2010. First evidence of estrogenic potential of the cyanobacterial heptotoxins the nodularin-R and the microcystin-LR in cultured mammalian cells. Journal of Hazardous Materials 174(1-3):610-5.

Paerl, H. W., and J. Huisman. 2009. Climate change: a catalyst for global expansion of harmful cyanobacterial blooms. Environmental Microbiology Reports 1(1):27-37.

Palíková, M., and coauthors. 1998. The effect of Pure Microcystin LR and Biomass of BlueGreen Algae on Selected Immunological Indices of Carp (Cyprinus Carpio L.) and Silver Carp (Hypophthalmichthys molitrix Val.). Acta Veterinaria Brno 67(265-272).

Pavagadhi, S., and R. Balasubramanian. 2013. Toxicological evaluation of microcystins in aquatic fish species: current knowledge and future directions. Aquatic Toxicology 142143:1-16.

Pawlik-Skowrońska, B., R. Kalinowska, and T. Skowroński. 2013. Cyanotoxin diversity and food web bioaccumulation in a reservoir with decreasing phosphorus concentrations and perennial cyanobacterial blooms. Harmful Algae 28:118-125.

Petersen, K., M. T. Hultman, and K. E. Tollefsen. 2017. Primary hepatocytes from Arctic char (Salvelinus alpinus) as a relevant Arctic in vitro model for screening contaminants and environmental extracts. Aquatic Toxicology 187:141-152.

Pflugmacher, S., and coauthors. 1998. Identification of an enzymatically formed glutathione conjugate of the cyanobacterial hepatotoxin microcystin-LR: the first step of detoxication. Biochimica et Biophysica Acta 1425(3):527-533.

Rebl, A., T. Goldammer, and H. M. Seyfert. 2010. Toll-like receptor signaling in bony fish. Vet Immunol Immunopathol 134(3-4):139-50.

Riccardi, C., and I. Nicoletti. 2006. Analysis of apoptosis by propidium iodide staining and flow cytometry. Nature Protocols 1(3):1458-61.

Rogers, E. D., and coauthors. 2011. Global gene expression profiling in larval zebrafish exposed to microcystin-LR and microcystis reveals endocrine disrupting effects of Cyanobacteria. Environmental Science and Technology 45(5):1962-9.

Routledge, E. J., and J. P. Sumpter. 1996. Estrogenic activity of surfactants and some of their degradation products assessed using a recombinant yeast screen. Environmental Toxicology and Chemistry 15(3):241-248.

Runnegar, M., N. Berndt, S.-M. Kong, E. Y. C. Lee, and L. Zhang. 1995. In vivo and In vitro binding of microcystin to protein phosphatases 1 and 2a. Biochemical and Biophysical Research Communications 216(1):162-169. 
Rymuszka, A., and L. Adaszek. 2012. Pro- and anti-inflammatory cytokine expression in carp blood and head kidney leukocytes exposed to cyanotoxin stress--an in vitro study. Fish and Shellfish Immunology 33(2):382-8.

Rymuszka, A., and L. Adaszek. 2013. Cytotoxic effects and changes in cytokine gene expression induced by microcystin-containing extract in fish immune cells--an in vitro and in vivo study. Fish and Shellfish Immunology 34(6):1524-32.

Rymuszka, A., A. Sieroslawska, A. Bownik, and T. Skowronski. 2010. Microcystin-LR modulates selected immune parameters and induces necrosis/apoptosis of carp leucocytes. Environmental Toxicology and Chemistry 29(3):569-74.

Sanseverino, J., and coauthors. 2009. Screening of potentially hormonally active chemicals using bioluminescent yeast bioreporters. Toxicological Sciences 107(1):122-34.

Sanseverino, J., and coauthors. 2005. Use of Saccharomyces cerevisiae BLYES expressing bacterial bioluminescence for rapid, sensitive detection of estrogenic compounds. Applied and Environmental Microbiology 71(8):4455-60.

Segner, H., A. Casanova-Nakayama, R. Kase, and C. R. Tyler. 2013. Impact of environmental estrogens on Yfish considering the diversity of estrogen signaling. General and Comparative Endocrinology 191:190-201.

Senthilkumaran, B. 2015. Pesticide- and sex steroid analogue-induced endocrine disruption differentially targets hypothalamo-hypophyseal-gonadal system during gametogenesis in teleosts - A review. General and Comparative Endocrinology 219:136-42.

Setchell, K. D., and C. Clerici. 2010. Equol: history, chemistry, and formation. The Journal of Nutrition 140(7):1355S-62S.

Sierlslawska, A. 2010. Immunotoxic, genotoxic and carcinogenic effects of cyanotoxins. Central European Journal of Immunology 35(2):105-110.

Snow, D. D., S. L. Bartelt-Hunt, D. L. Brown, J. Sangster, and D. A. Cassada. 2010. Detection, Occurrence and Fate of Pharmaceuticals and Steroid Hormones in Agricultural Environments. Water Environment Research 82(10):869-882.

Štěpánková, T., L. Ambrožová, L. Bláha, J. P. Giesy, and K. Hilscherová. 2011. In vitro modulation of intracellular receptor signaling and cytotoxicity induced by extracts of cyanobacteria, complex water blooms and their fractions. Aquatic Toxicology 105(34):497-507.

Sunyer, J. O. 2012. Evolutionary and Functional Relationships of B Cells from Fish and Mammals: Insights into their Novel Roles in Phagocytosis and Presentation of Particulate Antigen. Infectious Disorders - Drug Targets 12(3):200-212.

Sychrová, E., and coauthors. 2012. Estrogenic activity in extracts and exudates of cyanobacteria and green algae. Environment International 39(1):134-40.

Wang, C., and coauthors. 2016. Equol Induces Gonadal Intersex in Japanese Medaka (Oryzias latipes) at Environmentally Relevant Concentrations: Comparison with 17beta-Estradiol. Environmental Science and Technology 50(14):7852-60. 
Wei, L., B. Sun, L. Song, and P. Nie. 2008. Gene expression profiles in liver of zebrafish treated with microcystin-LR. Environmental Toxicology and Pharmacology 26(1):6-12.

Welker, M., and H. von Dohren. 2006. Cyanobacterial peptides - nature's own combinatorial biosynthesis. FEMS Microbiology Reviews 30(4):530-63.

WHO. 1998. Cyanobacterial toxins: Microcystin-LR in Drinking-water.

Wood, S. A., and coauthors. 2010. Identification of a benthic microcystin-producing filamentous cyanobacterium (Oscillatoriales) associated with a dog poisoning in New Zealand. Toxicon 55(4):897-903.

Xie, L., and coauthors. 2005. Organ distribution and bioaccumulation of microcystins in freshwater fish at different trophic levels from the eutrophic Lake Chaohu, China. Environmental Toxicology 20(3):293-300.

Young, J., L. Iwanowicz, A. Sperry, and V. Blazer. 2014. A landscape-based reconnaissance survey of estrogenic activity in streams of the upper Potomac, upper James, and Shenandoah Rivers, USA. Environmental Monitoring and Assessment. 186:5531-5545.

Zegura, B., A. Straser, and M. Filipic. 2011. Genotoxicity and potential carcinogenicity of cyanobacterial toxins - a review. Mutation Research 727(1-2):16-41.

Zhao, Y., L. Xie, and Y. Yan. 2015. Microcystin-LR impairs zebrafish reproduction by affecting oogenesis and endocrine system. Chemosphere 120:115-122.

Zhao, Z., and coauthors. 2017. The effects of emodin on cell viability, respiratory burst and gene expression of Nrf2-Keap1 signaling molecules in the peripheral blood leukocytes of blunt snout bream (Megalobrama amblycephala). Fish and Shellfish Immunology 62:75-85. 


\title{
Chapter Two. Temporal associations among cyanotoxins in water and fish tissue at various sites in the upper and middle Potomac River drainage, USA
}

\begin{abstract}
Microcystin (MC) toxins are exclusively produced by cyanobacteria. Historically, blooms of pelagic-oriented cyanobacteria have been documented in the Potomac River watershed. We investigated the occurrence of MCs in the upper and middle Potomac River watershed. We sampled both the filtered and whole (unfiltered) water fractions to determine the relative contribution of pelagic-oriented MC-producing taxa; as well as the periphyton to determine the contribution from benthic-oriented MC-producing taxa. Samples were collected at sites throughout Maryland, Virginia, and West Virginia monthly (or bi-monthly) for 28 months. We compared these MC concentrations to both in-stream physical metrics, as well as nutrient parameters. We also sampled smallmouth bass (Micropterus dolomieu) and golden redhorse sucker (Moxostoma erythrurum) at 19 time points to quantify the accumulation of MCs in hepatic tissue. All MC data were quantified using an enzyme-linked immunosorbent assay (ELISA). We observed relatively low concentrations of MCs in water, periphyton, and livers at all of the sites sampled as compared to acutely toxic concentrations reported in literature and the World Health Organization guideline for microcystin-LR in drinking water $(1.0 \mu \mathrm{g} / \mathrm{L})$. We observed seasonal variability of MCs in the water column that positively correlated to stream temperature. We observed seasonal variability of MCs in hepatic tissue similar to those observed in the water column. Overall, although the concentrations of MCs are low, we believe further investigation into the specific taxa present in each fraction, as well as overall biomass may yield a fuller picture to the initial research presented here.
\end{abstract}




\section{Introduction}

Cyanobacteria are found throughout marine, freshwater, and terrestrial habitats. Some genera of cyanobacteria produce chemical toxins (cyanotoxins) that have been implicated in human and animal illness and death (Codd et al. 2005; Lopez et al. 2008). Toxins may also be produced by eukaryotic taxa (Landsberg 2002). The generic term for these compounds produced by both prokaryotic and eukaryotic organisms is algal toxins. Algal toxins can be grouped according to their primary effects which include neurotoxins, hepatotoxins, cytotoxins and irritants (Sivonen and Jones 1999). A number of taxa have been identified that produce these toxins (Carmichael 1992, 1997; Dittmann and Wiegand 2006; Leflaive and Ten-Hage 2007). Under the current climate change projections, there is an increased growing global concern over the increased distribution and frequency of harmful algal blooms (Paerl and Huisman 2009).

Cyanobacterial-derived hepatotoxins are a family of cyanotoxins that are characterized by their toxic effects on liver tissue. The hepatotoxin microcystin (MC) is an extensively studied cyanotoxin in the environment comprising up to $1 \%$ dry weight of the total cyanobacteria biomass (Blaha et al. 2009; Pavagadhi and Balasubramanian 2013). Microcystin is a cyclic heptapeptide with over 80 known structural variants (Welker and von Dohren 2006). Microcystins are potent inhibitors of serine/threonine-specific protein phosphatases 1 and $2 \mathrm{~A}$ (Runnegar et al. 1995). The inhibition of these enzymes causes the dysregulation of intracellular glycogen, as well as the collapse of sinusoidal capillaries which results in hemorrhaging (Dawson 1998; Dittmann and Wiegand 2006). The presence and effects of MCs are well documented in the environment (O’Neil et al. 2012; Pawlik-Skowrońska et al. 2013; Quiblier et al. 2013) and the distribution of MC concentrations have been shown to fluctuate seasonally (Billam et al. 2006). Although much of the documented effects from MC exposure focuses on 
acute toxicity, there is some research correlating chronic MC exposure to carcinogenesis (Zegura et al. 2011), immune dysfunction (Liu et al. 2015) and other sublethal effects. Cyanotoxins have also been shown to bioacumulate (Ferrao-Filho Ada and Kozlowsky-Suzuki 2011) and consequently are important when assessing ecosystem health.

Krogmann et al. (1986) documented cyanobacterial blooms in the lower Potomac River in 1983 and reports suspected blooms in other areas of the watershed as early as 1930 . The causes of these blooms are unclear; however it is suggested that they were in part driven by excess nutrients and low water years. Between 2002 and 2009, various mortality events were documented involving smallmouth bass (SMB; Micropterus dolomieu). Blazer et al. (2010) conducted an exhaustive analysis and identified a variety of stressors which may have driven those events. Despite no correlation to a specific pathogen, there is considerable interest among fisheries managers to prevent such events in the future. The occurrence and distribution of cyanotoxins within the Potomac River watershed is poorly understood. This data gap is of interest given that cyanotoxins are known to bioacumulate in fish tissue (Ferrao-Filho Ada and Kozlowsky-Suzuki 2011). The evaluation of cyanotoxins, specifically the accumulation of MCs within fish tissue from individuals collected within the Potomac River drainage may yield insights into the risk factors associated with degraded fish health observed in certain areas of the watershed (Blazer et al. 2010). Our objective was to quantify the abundance and distribution of MCs in the water column and periphyton, as well as the bioaccumulation in hepatic tissues from fishes within the Potomac River drainage. 


\section{Methods}

\section{$\underline{\text { Field Collection }}$}

We selected 15 sites from streams located in the Potomac River watershed in West Virginia, Maryland, and Virginia (Figure 1; Reconnaissance Sites). Each site was sampled oncemonthly beginning June 26, 2013 through June 18, 2014, resulting in 11 sampling periods (we were unable to collect samples in October 2013 due to the Federal government shutdown). Due to spatial logistics, all 15 sites were sampled in the same sample period which was conducted approximately within the same week. Nine sites were sampled in the South Branch of the Potomac River basin, one site on the North Branch of the Potomac River, three sites in the Shenandoah River basin, one site on the mainstem of the Potomac River upstream from the confluence with the Shenandoah River, and one site near the mouth of the Monocacy River.

At each sampling location, two discrete water samples were collected from a near-shore location using one chemically cleaned 1L amber glass bottles (labelled filtered; I-Chem, Rockwood, Tennessee) and one sterile 500 mL HDPE bottle (labelled unfiltered; Thermo Fisher Scientific, Waltham, Massachusetts). Filtered samples were analyzed to identify cyanotoxins present free in the water column while unfiltered samples account for cellular and acellular toxins. Periphyton was collected by scraping organic benthic material from the surface of submerged rocks and woody debris into a sterile $50 \mathrm{~mL}$ conical tube (Becton Dickenson, Franklin Lakes, New Jersey). We targeted benthic mats of periphyton that were dark green, of leathery texture and emitted the strong odor of 2-methylisoborneol. Samples from similar mats collected by West Virginia Division of Natural Resources before and within our sampling period contained the toxin-producing cyanobacteria genera Microcoleus, Oscillatoria, and Phormidium (Table 1). Water temperature $\left({ }^{\circ} \mathrm{C}\right), \mathrm{pH}$, and conductivity $(\mu \mathrm{S} / \mathrm{cm})$ were recorded at each site 
using an Oakton® CON 10 Meter (Oakton Instruments, Vernon Hills, Illinois). Total dissolved oxygen (mg/L and percent) was recorded at each site using an Accumet AP74 Meter (Fisher Scientific, Pittsburgh, Pennsylvania).

Following the 12-month reconnaissance sample period, two sites in the South Branch Potomac and one site in the North Branch Potomac were sampled every other week from June 30, 2014 through December 14, 2015 (Figure 1; Biweekly Sites). This was done to increase the temporal resolution given the stability of MCs in the environment ( $<50 \%$ reduction in 16 days simulating wild streams and $<14 \%$ reduction in 26 days under ideal laboratory conditions as described by Tsuji et al. (1994)). These three sites were sampled on the same day and each sampling day was analyzed within its calendar month. Along with the above-mentioned water quality measurements, we also sampled five nutrient parameters. These were total nitrogen (N; $\mathrm{mg} / \mathrm{L}$ ), total phosphorous (P; mg/L), and total dissolved phosphorous (TDP; mg/L) in the water column, as well as total $\mathrm{N}(\mathrm{mg} / \mathrm{kg})$ and total $\mathrm{P}(\mathrm{mg} / \mathrm{kg})$ in the sediment. These samples were collected using one sterile $500 \mathrm{~mL}$ HDPE bottles (Thermo Fisher Scientific, Waltham, Massachusetts) for the aqueous metrics and one $250 \mathrm{~mL}$ pre-cleaned to EPA standards glass amber bottles (Quality Environmental Containers, Beaver, West Virginia) for the sediment metrics. All nutrient samples were analyzed and reported by Research Environmental Industrial Consultants Inc. (Beaver, West Virginia). Neither medium was filtered prior to shipment.

Smallmouth bass and golden redhorse suckers (GRH; Moxostoma erythrurum) were collected by the West Virginia Division of Natural Resources using boat electrofishing. These species were selected to represent two potentially different cyanotoxin exposure routs based on their respective life histories (based on diet and habitat usage as define in Jenkins and Burkhead (1983)) A necropsy-based fish health analysis was performed on all individuals recording total 
length (mm), body weight (g), sex, and noting any grossly observable external abnormalities. Livers were collected from 256 SMB and 291 GRH for total MCs during 19 sampling events between March 29, 2013 and August 12, 2015 (Table 2). Livers of SMB were removed and weighed (nearest g) for calculation of hepatosomatic indices. Weight of GRH livers was not obtained due to the more diffuse organization. The modified Fulton's body condition factor $(\mathrm{K})$ was calculated for both SMB and GRH as follows: $100000 \mathrm{X}$ ((body weight-gonad weight)/total length $\left.{ }^{3}\right)$ ). The SMB hepatosomatic index (HSI) was calculated using the following formula: (liver weight/(body weight-gonad weight))*100. Liver tissue was placed in plastic bags, held on wet ice until returned to the laboratory (generally less than four hours, vacuum-sealed and stored at $-80^{\circ} \mathrm{C}$ until extraction.

\section{Laboratory Preparation}

Filtered water samples were acidified with hydrochloric acid to $\mathrm{pH} 3.0$ and stored at $4{ }^{\circ} \mathrm{C}$ for no greater than 14 days prior to filtration and extraction. Periphyton samples were centrifuged at $913 \mathrm{~g}$ for ten minutes. After centrifugation, the supernatant was removed retaining the periphyton pellet which was stored at $-20^{\circ} \mathrm{C}$ until filtration and extraction. Unfiltered water samples were stored at $-20^{\circ} \mathrm{C}$ until filtration and extraction.

Prior to extraction, unfiltered water samples were prepared by three freeze-thaw cycles as described by Loftin et al. (2008). Subsequently, all water samples were extracted using methods modified from Ciparis et al. (2012). Each sample was brought to room temperature and prefiltered using a $0.7 \mu \mathrm{m} \mathrm{AP40} \mathrm{GF/F} \mathrm{filter} \mathrm{(Millipore} \mathrm{Corporation,} \mathrm{Billerica,} \mathrm{Massachusetts).} \mathrm{We}$ prepared water samples using solid phase extraction via OASIS® HLB (200 mg) glass cartridges (Waters Corporation, Milford, Massachusetts). Cartridges were pre-cleaned using five $\mathrm{mL}$ each of ethyl acetate, 50:50 methanol:dichloromethane, methanol, and deionized water (pH adjusted 
to 3.0). $800 \mathrm{~mL}$ of the filtered or $400 \mathrm{~mL}$ of the unfiltered samples were run through the cartridge via continuous vacuum. We then used two consecutive $6 \mathrm{~mL}$ solvents containing methanol then 50:50 methanol:dichloromethane and reduced to dryness. Eluates were solubilized in methanol such that the final extraction ratio was $1600: 1$. Extracted samples were stored at $-20^{\circ} \mathrm{C}$ until analysis.

Periphyton samples were extracted using methods modified from Mohamed et al. (2006). Prior to extraction, periphyton samples were lysed by three freeze-thaw cycles as described by Loftin et al. (2008). Samples were weighed and $6 \mathrm{~mL}$ of absolute methanol was added. Samples were vortexed for three minutes, followed by centrifugation at $913 g$ for ten minutes. Supernatant was retained and the process was repeated a second time with 50:50 methanol:dichloromethane. Each supernatant sample was filtered using a $0.7 \mu \mathrm{m}$ Whatman ${ }^{\circledR}$ Purdisc 13 syringe filter (Whatman, Maidstone, United Kingdom). Once filtered, both samples were reduced to dryness, then solubilized with methanol and pooled such that the final sample volume was $500 \mu \mathrm{L}$. Samples were stored at $-20^{\circ} \mathrm{C}$ until analysis.

Liver samples were extracted twice using methods described by Deblois et al. (2008). Whole livers were thawed, weighed, and minced into small pieces in a Falcon ${ }^{\circledR} 15 \mathrm{~mL}$ conical tube (Corning Inc., Corning, New York). Six mL of absolute methanol was added, sonicated for one minute at low intensity and then placed on a rotary mixer at $4^{\circ} \mathrm{C}$ for three hours. The samples were then centrifuged for 20 minutes at $913 g$ and supernatant removed through a $0.7 \mu \mathrm{m}$ Whatman® Purdisc 13 syringe filter (Whatman, Maidstone, United Kingdom). Filtered supernatants were reduced to dryness, re-solubilized with $500 \mu \mathrm{L}$ absolute methanol and stored at $-20^{\circ} \mathrm{C}$ until analysis. 


\section{Direct competitive ELISA protocol}

ELISA methods were adapted from Campas and Marty (2007) to quantify total microcystins/nodularins. These ELISA results will be referred to as total MC/NOD. Wells were coated with $100 \mu \mathrm{L}$ of ADDA-specific mAb $(0.1 \mu \mathrm{g} / \mathrm{mL}$ (diluted in carbonate buffer; $\mathrm{pH} 9.6)$; AD4G2; Enzo Life Sciences, Farmingdale, New York) and incubated in a 96-well ELISA plate (Costar® 3396, Corning Inc., Corning, New York) for 18 hours at $4^{\circ} \mathrm{C}$. Plates were washed 5 times with tris-buffered saline with $0.0005 \%$ Tween-20 (TBST; pH 7.4), and blocked with TBST with $1 \%$ bovine serum albumin (block buffer; $\mathrm{pH} 7.4$ ) for two hours at $37^{\circ} \mathrm{C}$. Each plate was washed 5 times with TBST and $50 \mu \mathrm{L}$ of standards (11 standards ranging from $0.078-500.0$ $\mathrm{ng} / \mathrm{mL}$ as well as a solvent control) or sample was added at a $5 \%$ dilution in block buffer. $50 \mu \mathrm{L}$ of biotin-labelled MC-LR was added to each well $(4 \mu \mathrm{g} / \mathrm{mL})$ in block buffer and incubated for 1.5 hours at $37^{\circ} \mathrm{C}$. Plates were washed five times with TBST and $100 \mu \mathrm{L}$ of streptavidinhorseradish peroxidase conjugate (1:5000 in block buffer; ThermoFisher Scientific, Waltham, Massachusetts) was added and incubated for 30 minutes at $37^{\circ} \mathrm{C}$. Plates were washed five times with TBST and $100 \mu \mathrm{L}$ of SureBlue Reserve ${ }^{\mathrm{TM}}$ TMB Microwell Peroxidase Substrate (Kirkegaard \& Perry Laboratories, Inc., Gaithersburg, Maryland) was added and incubated at $25^{\circ} \mathrm{C}$ for 1.5 hours. $50 \mu \mathrm{L}$ of TMB stop solution (Kirkegaard \& Perry Laboratories, Inc., Gaithersburg, Maryland) was added and optical density was measures at $450 \mathrm{~nm}$ using a SpectraMax M4 plate reader (Molecular Devices LLC, Sunnyvale, California). Sample concentration was determined by interpolation to the standard curve and adjusted for sample concentration. Values are reported as $\mathrm{ng} / \mathrm{mL}$ for filtered and unfiltered water and $\mathrm{ng} / \mathrm{g}$ for periphyton and liver samples. 
To validate the direct competitive ELISA for water and liver extracts a subset of samples was analyzed with a commercially available indirect competitive ELISA for total microcystin/nodularin kit (Abraxis, Inc., Warminster, Pennsylvania). We compared our standards as well as filtered and unfiltered water samples using Abraxis kit product number 520011. To compare the sensitivity and dynamic range of our ELISA to the Abraxis kit, we calculated the average from 20 standard curves and compared this to the Abraxis standard curve. Periphyton, SMB, and GRH liver sample extracts were compared using Abraxis kit product number 520011SAES. Both kits use the same polyclonal antibody and have a dynamic range from $0.05-$ $5.0 \mathrm{ng} / \mathrm{mL}$.

$\underline{\text { Statistical Analysis }}$

All data were analyzed using the R statistical software package (R Core Development Team, 2017) and considered significantly different at $\alpha=0.05$. Validation of the ELISA method and comparison of the standard curves used a 4-parameter logistic regression in the R package $n p l r$. Correlation among the two curves used the R package $d r c$. Finally, we compared the interpreted results from the Abraxis and our assays among each of the mediums (filtered water, unfiltered water, periphyton, SMB liver, and GRH liver). Comparison of filtered and unfiltered water samples was performed using the Pearson's correlation. Differences within season/year among these water samples were assessed using a Student's t-test. Variability among sampling sites of water and periphyton data was analyzed separately for the initial 12 months and subsequent 16 month sampling efforts using an analysis of variance (ANOVA) followed by the Tukey's honest significance difference test if a significant difference was detected. We defined season by grouping three consecutive months as follows: spring was between March, April, and May; summer was between June, July, and August; fall was between September, October, and 
November; winter was between December, the following January, and February (the year associated with winter corresponds to January and February). If there was no statistical difference among sites, differences among season/year were quantified using an ANOVA followed by the Tukey's honest significance difference test. If there was a significant difference among sites, season/year differences were quantified in the linear mixed effects model (LMM) framework treating "site" as a fixed effect. This was performed with the R package nlme (Pinheiro et al. 2013) using a ANOVA (type III sums of squares) followed the Tukey's honest significance difference test if a significant difference was detected.

The linear mixed effects models package nlme was also used to define and quantify the explanatory variables responsible for variation in the MC/NOD dataset. The initial model selection framework analyzed the total MC/NOD among all 15 sites during the initial 12 months sampling period. First, we analyzed the global effects of stream discharge $\left(\mathrm{ft}^{3} / \mathrm{s}\right)$, temperature $\left({ }^{\circ} \mathrm{C}\right)$, conductivity $(\mu \mathrm{S} / \mathrm{cm})$, and $\mathrm{pH}$ accounting for the seasonal and site variation from the initial models (if applicable). To analyze the subsequent 16 months, we built two separate models due to the limited number of sites (three) given the total amount to variables investigated (six). The first model explored the effects of four physical variables described above on total MC/NOD in the water column and periphyton. The second model incorporated the top candidate model(s) along with the $\mathrm{N}$ and $\mathrm{P}$ variables. We discarded TDP from analysis due to the high frequency of data below the reporting limit (104 of 117 total samples).

Effects of sex, age, or tissue weight on total MCs in liver was performed with a one-way ANOVA. Seasonal and site differences were determined using a one-way ANOVA. Pairwise comparisons were assessed using the Tukey's honest significance difference test. Species differences within sampling site and sampling effort were quantified using either the Student's or 
Welch's t-test depending on equal or unequal variances as reported with an F-test. When applicable, we compared K and HSI to total MCs in the liver using the Pearson's correlation.

\section{Results}

\section{ELISA Comparison/Validation}

Standard curve from both assays are presented in Figure 2. Our standards fall within the error of the commercial kit's standard curve. The inflection points are $-1.43,1.44$ and -0.904 , 1.12 for the Abraxis and our curves, respectively (Figure 3). There was no significant difference among these curves $(\mathrm{p}=0.062)$. The comparison from the Abraxis kit and our assay among the five sample extract medium's (filtered water, unfiltered water, periphyton, SMB liver, and GRH liver) are presented in Table 4 . Among water samples, the data were within the reported range \pm three standard deviations between the two assays or our assay overestimated as compared to the Abraxis kit. However, $36 \%$ of the unfiltered water samples quantified were above the reporting limit of the Abraxis kit. These samples were quantifiable without dilution using our assay. $100 \%$ of the GRH livers were within the reporting range among the two assays. There was no discernable pattern for periphyton and SMB livers between the two assays.

\section{Quantification of Total Microcystins in Water Samples}

A total of 288 filtered and 288 unfiltered water samples were analyzed. MC/NOD were detected in $40.5 \%$ of all water samples. The concentrations of MC/NOD in water ranged from 1.30 to $88.7 \mathrm{ng} / \mathrm{L}$ (Table 5). The overall trends among filtered and unfiltered water samples were significantly correlated $\left(\mathrm{p}<0.001, \mathrm{r}^{2}=0.342\right)$. However, our initial analysis was designed to quantify differences within season/year between these two mediums. These data are reported in Table 6. As predicted, the unfiltered water samples had an MC/NOD concentration greater than 
or equal to the concentration reported in filtered water once adjusted for standard error within each sampling season/year. During the summer and fall 2013 and fall 2015, unfiltered water had a higher MC/NOD concentration than filtered water $(\mathrm{p} \leq 0.026)$. The source of these differences is unknown.

$\underline{\text { Site and Seasonal Differences among Water and Periphyton Samples }}$

There were no significant temporal differences among all sites among season/year when we compared total MC/NOD in the water column during the initial 12 months using filtered $(\mathrm{p}=$ $0.144)$ or unfiltered $(\mathrm{p}=0.856)$. We then examined site differences among all sites within season/year. Although we were unable to statistically compare site differences at this temporal scale based on minimal sampling points within each season/year $(n \leq 3)$, we do note differences. For example, unfiltered samples from the three South Branch mainstem sites were consistently higher than the remaining 12 sites during both summer months. However these are only higher in the summer 2014 filtered water samples. The highest value during the summer 2013 was the North Fork of the South Branch while the highest value in the summer 2014 was the South Branch tributary at Mill creek near Romney, WV. We also note that the ten North and South Branch Potomac sites were generally higher for both filtered and unfiltered as compared to the three Shenandoah River sites, one mainstem Potomac River site, and one Monocacy River site. During the subsequent 16 months, we observed a significant difference among sites using both filtered and unfiltered water $(\mathrm{p}=0.003$ and $\mathrm{p}<0.001$, respectively). The two South Branch sites were both significantly higher $(\mathrm{p} \leq 0.021)$ than the one North Branch Potomac site but were not different from each another $(\mathrm{p}=0.480)$.

The summer and fall 2013 filtered samples were higher than the 2014 spring samples $(\mathrm{p}<$ 0.001 for both). The spring 2014 filtered water samples were lower than the winter and summer 
$2014(\mathrm{p}=0.001$ and $\mathrm{p}<0.001$, respectively). The 2013 summer unfiltered water samples were higher than the other four seasons $(\mathrm{p} \leq 0.002)$. The 2013 fall unfiltered water samples were higher than the 2014 winter and spring unfiltered water samples ( $p<0.001$ for both). During the biweekly sampling period, seasonal differences in both water sample types were again largely observed in the summer months. When we examined filtered water, 2014 summer was higher than all other season/year except for 2016 winter $(\mathrm{p}<0.001)$. Summer 2015 was higher than 2015 autumn $(\mathrm{p}=0.040)$. When we evaluated unfiltered samples, 2014 summer was higher than other season/year except for 2016 winter $(\mathrm{p}<0.001)$. There were no additional statistical differences.

A total of 288 periphyton samples were analyzed. MC/NOD was reported in $76 \%$ of these samples. The range was between 0.280 and $222.620 \mathrm{ng} / \mathrm{g}$ (Table 5). We analyzed the periphyton in the initial 12 month and subsequent 16 month groups as described above. During both time frames, there was no significant difference among sites $(\mathrm{p}=0.444$ and 0.908 , respectively). We did observe a significant difference among season/year ( $p<0.001$ and 0.006 , respectively). Samples collected in summer 2013 were lower than winter and spring 2014 ( $\mathrm{p}<0.001$ ). During the biweekly sampling period, spring 2015 samples were lower than fall of $2014(\mathrm{p}=0.039)$ and $2015(0.018)$ samples. The summer 2014 was lower than the fall of 2015 (p $=0.041)$.

Explanatory Variable Data Analysis for Water and Periphyton Samples

All model exploration results are summarized in Table 7. We quantified total MC/NOD in the water column during the initial 12 months as a function of our four physical explanatory variables (water temperature, discharge, $\mathrm{pH}$, and conductivity) given the difference among season and year. Based on the model results, temperature and $\mathrm{pH}$ were identified as yielding high 
importance to the model ( 0.94 and 0.88 , respectively). When analyzing unfiltered samples, conductivity was identified to be the most important variable (0.69).

During the subsequent 16 months of sampling, we included sample site as a fixed effect to account for the known site differences described above for both methods. When we examined the model results for our physical parameters, similar to the initial time range, only temperature was supported by the model for filtered samples (1.00) and by our unfiltered sample model (0.96). We then built a final model for each sample type which included total $\mathrm{N}$ and total $\mathrm{P}$ in the water column, as well as water temperature (the top candidate models from above) within the biweekly date range. Again, only temperature was identified to be the most important for filtered and unfiltered samples (1.00 and 0.99 , respectively).

We attempted to correlate the total MC/NOD in the periphyton using either our four physical explanatory variables or the two nutrient variables (total $\mathrm{N}$ and total $\mathrm{P}$ in the sediment) during both of our time periods given the known differences in season/year as described above. Based on the model results, there were no variables that were supported by any model to explain the MC/NOD variance among the periphyton.

\section{Total Microcystins in Liver Samples}

A summary of average fish length, weight, age, and total MC/NOD for each site and sampling effort is provided in Table 8 . We detected MC/NOD in $81 \%$ of SMB and $80 \%$ of GRH samples (Table 8). The range among SMB was 0.130 to $29.144 \mathrm{ng} / \mathrm{g}$ and the range among GRH was 0.182 to $22.738 \mathrm{ng} / \mathrm{g}$. There was no significant effect of age, sex, or total liver weight among either species analyzed. We observed seasonal variability within sites and within species. Values during the summer sampling season were significantly higher as compared to the spring 
sampling season at the two South Branch Potomac sites (Petersburg and Moorefield, WV). We were able to compare seasonal differences among GRH at three sites (North Branch at Cumberland, MD and the South Branch at Petersburg and Moorefield, WV). There was a similar trend for higher total MC/NOD concentrations in the summer compared to the spring. However we note high annual variability in GRH. During nine sampling events, we collected both SMB and GRH. We observed higher MC/NOD in SMB as compared to GRH at the mainstem of the North Branch at Cumberland, MD on 4/8/2013 ( $\mathrm{p}=0.039)$ and during both the $4 / 5 / 2013$ and 8/27/2014 samplings at the mainstem of the South Branch near Moorefield, WV $(\mathrm{p}=0.030$ and $\mathrm{p}$ $<0.001$, respectively). There were no other significant differences among species.

Among SMB, there was a general decreasing trend in HSI when we compared spring and summer samples regardless of year (Table 8). There was a similar trend with K. Both HSI and K are inversely correlated to total MC/NOD ( $\mathrm{p}<0.001$ and $\mathrm{p}=0.009$, respectively). The $\mathrm{K}$ of GRH followed a similarly decreasing trend. However, $\mathrm{K}$ was not correlated to total MC/NOD ( $\mathrm{p}=$ 0.232).

\section{Discussion}

The MC/NOD concentrations we observed in the environment were much lower than the World Health Organization guideline for MC-LR in drinking water of $1 \mathrm{ng} / \mathrm{mL}$ (WHO 2011) and MC/NOD concentrations reported in other systems (the highest MC/NOD reported in individual water samples from the present study were $0.051 \mathrm{ng} / \mathrm{mL}$ in filtered water and $0.090 \mathrm{ng} / \mathrm{mL}$ in unfiltered water). Wood et al. (2006) documented benthic-oriented cyanobacteria in New Zealand and those taxa are similar to the cyanobacteria reported in the middle and upper Potomac River watershed (Table 1). Six of the 10 streams Wood et al. (2006) sampled contained detectable concentrations of MCs. They report a concentration in the water column of one 
system to be $12.70 \mu \mathrm{g} / \mathrm{L}$ which is four orders of magnitude higher than those we observed. They also reported detectable concentrations of MCs in the benthos in five of their streams. The concentrations we detected among periphyton (ranging from 0.28 to $222.62 \mathrm{ng} / \mathrm{g}$ ) overlap the range of MCs they report ( 2.1 to $200 \mathrm{ng} / \mathrm{g}$ ) among the benthos. A variety of hypotheses have been proposed to explain why cyanobacteria release toxins into the environment (e.g. defense mechanism and/or actively reducing competition (Sivonen 2009)). This may (in-part) explain the relatively elevated concentrations of $\mathrm{MC} / \mathrm{NOD}$ we observed in the summer months. These are generally characterized by warmer water with lower discharge which likely leads to increased growth, competition for available habitat, and immigration of cyanobacterial grazers. All of these factors (which would need to be independently investigated) may influence the release of toxins into the water column.

We attempted to identify the likely source population of MC-producing cyanobacteria in either the pelagic or benthic community by temporally sampling both populations. As highlighted in Table 6, the benthic concentration peaks in the autumn while the pelagic concentration peaks in the summer. Interestingly, the trend of the unfiltered samples correlated to the trend of the filtered samples which would suggest that it is the pelagic community which is driving total MCs in the water. We cannot however rule out the possibility of benthic taxa becoming dislodged and contributing to water concentrations; however we note that the seasonal peak MC/NOD concentrations in water was generally earlier than periphyton. Identification of the specific taxa present in each population would be required to confirm or reject this hypothesis. The concentrations of MC/NOD observed in the water are well below the concentration that has induced a biological effect experimentally. In an aqueous challenge using female zebrafish (Danio rerio), Zhao et al. (2015) observed a change in reproductive endpoints 
(molecular and histological) at concentrations of MC >10 ng/mL. In a different challenge using medaka (Oryzias latipes), Mezhoud et al. (2008) observed a change in hepatic molecular markers at a concentration of MC $>1000 \mathrm{ng} / \mathrm{mL}$. However, it is unclear how a prolonged exposure to particularly sub-lethal concentrations of MCs (such that we observed here) influence transcript abundance or histopathological markers in wild fishes.

Concentration of MC/NOD in SMB and GRH in hepatic tissue was generally below those reported to cause biological effects in wild fishes from other watersheds. Mitsoura et al. (2013) evaluated common carp (Cyprinus carpio) from a lacustrine system experiencing cyanobacterial blooms of MC-producing taxa and reported MC concentrations in the water between 2.03 and $3.01 \mathrm{ng} / \mathrm{mL}$ and in the liver between 346 and $732 \mathrm{ng} / \mathrm{g}$. At these concentrations, they observed hepatocyte degradation and necrosis. Deblois et al. (2008) analyzed MC concentrations in the water and two tilapia species (Oreochromis niloticus and Tilapia rendalli) from impoundments in Brazil. They observed concentrations of MCs in the water column between 2710 and 9860 $\mathrm{ng} / \mathrm{mL}$ and in hepatic tissue between 800 and $2400 \mathrm{ng} / \mathrm{g}$. They suggested this resulted in a decreased HSI and K. As we also observed an inverse correlation among MC/NOD and HSI and $\mathrm{K}$ (in SMB), total MCs may be considered as a contributing factor as well as other possible external factors (e.g. temperature, DO, etc.). We sampled SMB and GRH to focus on two separate feeding strategies (higher-order piscivore and lower order omnivore). We generally did not observe differences in MC/NOD in the liver samples between these species. Further investigation is required to determine where MC/NOD is entering the food web.

We observed a correlation of MC/NOD in the water column to stream temperature but not other physical and nutrient variables. This may suggest that primary production is not limited by the availability of nutrients (specifically total $\mathrm{N}$, total $\mathrm{P}$, and TDP). These conclusions are 
similar to those reported by Munn et al. (1989) who used chlorophyll $a$ as a proxy for cyanobacterial abundance and correlations to temperature and turbidity were observed. They did not observe correlations between $\mathrm{N}$ or $\mathrm{P}$ in the substrate and it was concluded that primary production among streams within the sample areas was strictly limited by temperature and turbidity. We cannot, however, rule out nutrient loading as a variable of concern in these systems based on the results from a recent study of water quality metrics (including $\mathrm{N}$ and $\mathrm{P}$ ) at sites in the Shenandoah and South Branch Potomac Rivers (Buchanan and Mandel 2015). In addition, we have documented the presence of MC-producing taxa in the watersheds we sampled. Oscillatoria spp. is a known MC producer (Brittain et al. 2000) and has been identified in the Potomac River drainage (Table 1). The species $O$. limosa is capable of fixing atmospheric nitrogen and thus, would likely be limited by P (Fay 1992). A detailed time series analysis of taxa richness, as well as total MC concentrations and nutrient analysis would be required to fully understand the contribution of specific species rather than our broadly studied periphyton mat. These data would also allow ecosystem managers to fully understand the interaction of stream nutrients and the MC-producing taxa present in these streams.

Harmful algal blooms are of significant interest with regards to public health (Carmichael and Boyer 2016; Grattan et al. 2016; Wituszynski 2014; Chorus and Bartram 1999; Backer 2002). Overall, the concentrations present in water, periphyton, and fish tissue were low compared to data reported in literature and the guidelines set forth by the WHO. This is the first documentation of MC/NOD in these fish species at these sites. Although we observed variability in individual samples, the overall trend of higher concentrations during the warmer summer months was consistent across all sites. The specific source of MC/NOD reported in the water column remains unclear. Along with richness and biomass, further investigation into the 
successional stages in the periphyton as described by Momo (1995) and Brasell (2014) may yield insights into the variables influencing growth and release of MCs. These variables must include both physical and nutrient parameters as recommended by Biggs and Close (1989). Additionally, many cyanobacterial taxa are known to produce multiple toxins (Quiblier et al. 2013). An extensive investigation into specific species present, as well as the toxins they may produce (beyond MCs), would provide a fuller description of influence of cyanotoxins within these systems. 


\section{Literature Cited}

Backer, L. C. (2002). Cyanobacterial harmful algae blooms (CyanoHABs): Developing a public health response. Lake and Reservoir Management, 18(1), 20-31.

Biggs, B. J. F., \& Close, M. E. (1989). Periphyton biomass dynamics in gravel bed rivers: the relative effects of flows and nutrients. Freshwater Biology, 22(2), 209-231.

Billam, M., Tang, L., Cai, Q., Mukhi, S., Guan, H., Wang, P., et al. (2006). Seasonal variations in the concentration of microcystin-LR in two lakes in western Texas, USA. Environmental Toxicology and Chemistry, 25(2), 349-355.

Blaha, L., Babica, P., \& Marsalek, B. (2009). Toxins produced in cyanobacterial water blooms toxicity and risks. Interdiscipinary Toxicology, 2(2), 36-41.

Blazer, V. S., Iwanowicz, L. R., Starliper, C. E., Iwanowicz, D. D., Barbash, P., Hedrick, J. D., et al. (2010). Mortality of centrarchid fishes in the Potomac drainage: survey results and overview of potential contributing factors. Journal of Aquatic Animal Health, 22(3), 190218.

Brasell, K. A. (2014). Characterising the benthic Phormidium autumnale-dominated biofilm community and anatoxin production throughout biofilm succession. Victoria University of Wellington,

Brittain, S., Mohamed, Z. A., Wang, J., Lehmann, V. K. B., Carmichael, W. W., \& Rinehart, K. L. (2000). Isolation and characterization of microcystins from a River Nile strain of Oscillatoria tenuis Agardh ex Gomont. Toxicon, 38, 1759-1771.

Buchanan, C., \& Mandel, R. (2015). Water Quality Trend Analysis at Twenty-Six West Virginia Long-Term Monitoring Sites. Rockville, MD: Interstate Commission on the Potomac River Basin.

Campas, M., \& Marty, J. L. (2007). Highly sensitive amperometric immunosensors for microcystin detection in algae. Biosensors and Bioelectronics, 22(6), 1034-1040.

Carmichael, W. W. (1992). Cyanobacteria secondary metabolites- the cyanotoxins. Journal of Applied Bacteriology, 72, 445-459.

Carmichael, W. W. (1997). The cyanotoxins. Advances in Botanical Research, 27, 211-256.

Carmichael, W. W., \& Boyer, G. L. (2016). Health impacts from cyanobacteria harmful algae blooms: Implications for the North American Great Lakes. Harmful Algae, 54, 194-212.

Chorus, I., \& Bartram, J. (1999). Toxic Cyanobacteria in Water: A guide to their public health consequences, monitoring and management. World Health Organization.

Ciparis, S., Iwanowicz, L. R., \& Voshell, J. R. (2012). Effects of watershed densities of animal feeding operations on nutrient concentrations and estrogenic activity in agricultural streams. Science of the Total Environment, 414, 268-276.

Codd, G. A., Morrison, L. F., \& Metcalf, J. S. (2005). Cyanobacterial toxins: risk management for health protection. Toxicology and Applied Pharmacology, 203(3), 264-272.

Dawson, R. M. (1998). The toxicology of microcystins. Toxicon, 36(7), 953-932. 
Deblois, C. P., Aranda-Rodriguez, R., Giani, A., \& Bird, D. F. (2008). Microcystin accumulation in liver and muscle of tilapia in two large Brazilian hydroelectric reservoirs. Toxicon, 51(3), 435-448.

Dittmann, E., \& Wiegand, C. (2006). Cyanobacterial toxins--occurrence, biosynthesis and impact on human affairs. Molecular Nutrition and Food Research, 50(1), 7-17.

Fay, P. (1992). Oxygen relations of nitrogen fixation in cyanobacteria. Microbiological Reviews, $56(2)$.

Ferrao-Filho Ada, S., \& Kozlowsky-Suzuki, B. (2011). Cyanotoxins: bioaccumulation and effects on aquatic animals. Marine Drugs, 9(12), 2729-2772.

Grattan, L. M., Holobaugh, S., \& Morris, J. G. (2016). Harmful algal blooms and public health. Harmful Algae, 57, 2-8.

Jenkins, R. E., \& Burkhead, N. M. (1994.) Freshwater fishes of Virginia - $1^{\text {st }}$ edition. American Fisheries Society, Bethesda, Maryland.

Krogmann, D. W., Butalla, R., \& Sprinkle, J. (1986). Blooms of Cyanobacteria on the Potomac River. Plant Physiology, 80, 667-671.

Landsberg, J. H. (2002). The Effects of Harmful Algal Blooms on Aquatic Organisms. Reviews in Fisheries Science, 10(2), 113-390.

Leflaive, J. P., \& Ten-Hage, L. (2007). Algal and cyanobacterial secondary metabolites in freshwaters: a comparison of allelopathic compounds and toxins. Freshwater Biology, 52(2), 199-214.

Liu, Z., Tang, R., Li, D., Hu, Q., \& Wang, Y. (2015). Subacute microcystin-LR exposure alters the metabolism of thyroid hormones in juvenile zebrafish (Danio Rerio). Toxins (Basel), 7(2), 337-352.

Loftin, K. A., Meyer, M. T., Rubio, F., Kamp, L., Humphries, E., \& Whereat, E. (2008). Comparison of Two Cell Lysis Procedures for Recovery of Microcystins in Water Samples from Silver Lake in Dover, Delaware, with Microcystin Producing Cyanobacterial Accumulations. (pp. 9).

Lopez, C.B., Jewett, E.B., Dortch, Q., Walton, B.T., Hudnell, H.K. 2008. Scientific Assessment of Freshwater Harmful Algal Blooms. Interagency Working Group on Harmful Algal Blooms, Hypoxia, and Human Health of the Joint Subcommittee on Ocean Science and Technology. Washington, DC.

Mezhoud, K., Praseuth, D., Puiseux-Dao, S., Francois, J. C., Bernard, C., \& Edery, M. (2008). Global quantitative analysis of protein expression and phosphorylation status in the liver of the medaka fish (Oryzias latipes) exposed to microcystin-LR I. Balneation study. Aquatic Toxicology, 86(2).

Mitsoura, A., Kagalou, I., Papaioannou, N., Berillis, P., Mente, E., \& Papadimitriou, T. (2013). The presence of microcystins in fish Cyprinus carpio tissues: a histopathological study. International Aquatic Research, 5(1), 8. 
Mohamed, Z. A., El-Sharouny, H. M., \& Ali, W. S. M. (2006). Microcystin production in benthic mats of cyanobacteria in the Nile River and irrigation canals, Egypt. Toxicon, 47, 584-590.

Momo, F. R. (1995). A new model for periphyton growth in running waters. Hydrobiologia, 299, 215-218.

Munn, M. D., Osborne, L. L., \& Wiley, M. J. (1989). Factors influencing periphyton growth in agricultural streams of central Illinois Hydrobiologia, 174, 89-97.

O’Neil, J. M., Davis, T. W., Burford, M. A., \& Gobler, C. J. (2012). The rise of harmful cyanobacteria blooms: The potential roles of eutrophication and climate change. Harmful Algae, 14, 313-334.

Paerl, H. W., \& Huisman, J. (2009). Climate change: a catalyst for global expansion of harmful cyanobacterial blooms. Environmental Microbiology Reports, 1(1), 27-37.

Pavagadhi, S., \& Balasubramanian, R. (2013). Toxicological evaluation of microcystins in aquatic fish species: current knowledge and future directions. Aquatic Toxicology, 142143.

Pawlik-Skowrońska, B., Kalinowska, R., \& Skowroński, T. (2013). Cyanotoxin diversity and food web bioaccumulation in a reservoir with decreasing phosphorus concentrations and perennial cyanobacterial blooms. Harmful Algae, 28, 118-125.

Pinheiro, J., Bates, D., DebRoy, S., Sarkar D., the R Development Core Team, (2013). nlme: Linear and Nonlinear Mixed Effects Models. R Package Version 3.1-113.

Quiblier, C., Wood, S., Echenique-Subiabre, I. H., Marke, Villeneuve, A., \& Humbert, J.-F. (2013). A review of current knowledge on toxic benthic freshwater cyanobacteria-ecology, toxin production and risk management. Water Research, 47(15), 5464-5479.

R Core Development Team. (2017). R: A language and environment for statistical computing. Vienna, Austria: R Foundation for Statistical Computing.

Runnegar, M., Berndt, N., Kong, S.-M., Lee, E. Y. C., \& Zhang, L. (1995). In vivo and In vitro binding of microcystin to protein phosphatases 1 and 2a. Biochemical and Biophysical Research Communications, 216(1), 162-169.

Sivonen, K. (2009). Cyanobacterial Toxins. In M. Schaechter (Ed.), Encyclopedia of Microbiology (pp. 290-[307]). Oxford: Elsevier.

Tsuji, K., Naito, S., Kondo, F., Ishikawa, N., Watanabe, M. F., Suzuki, M., et al. (1994). Stability of microcystins from cyanobacteria: effect of light on decomposition and isomerization. Environmental Science and Technology, 28(1), 173-177.

Welker, M., \& von Dohren, H. (2006). Cyanobacterial peptides - nature's own combinatorial biosynthesis. FEMS Microbiology Reviews, 30(4), 530-563.

WHO (2011). Chemical Fact Sheets. In W. H. Organization (Ed.), Guidelines for drinking-water quality, fourth edition (pp. 564).

Wituszynski, D. M. (2014). Variation of Microcystin Concentrations in Fish Related to Algae Blooms in Lake Erie, and Public Health Impacts. Ohio State University, 
Wood, S. A., Holland, P. T., Stirling, D. J., Briggs, L. R., Sprosen, J., Ruck, J. G., et al. (2006). Survey of cyanotoxins in New Zealand water bodies between 2001 and 2004. New Zealand Journal of Marine and Freshwater Research, 40(4), 585-597.

Zegura, B., Straser, A., \& Filipic, M. (2011). Genotoxicity and potential carcinogenicity of cyanobacterial toxins - a review. Mutation Research, 727(1-2), 16-41.

Zhao, Y., Xie, L., \& Yan, Y. (2015). Microcystin-LR impairs zebrafish reproduction by affecting oogenesis and endocrine system. Chemosphere, 120, 115-122. 


\section{Figures}

Figure 1. The location of all 15 sites included in this study. All sites were located in the states of West Virginia, Maryland, and Virginia within the Potomac River watershed (inset map).

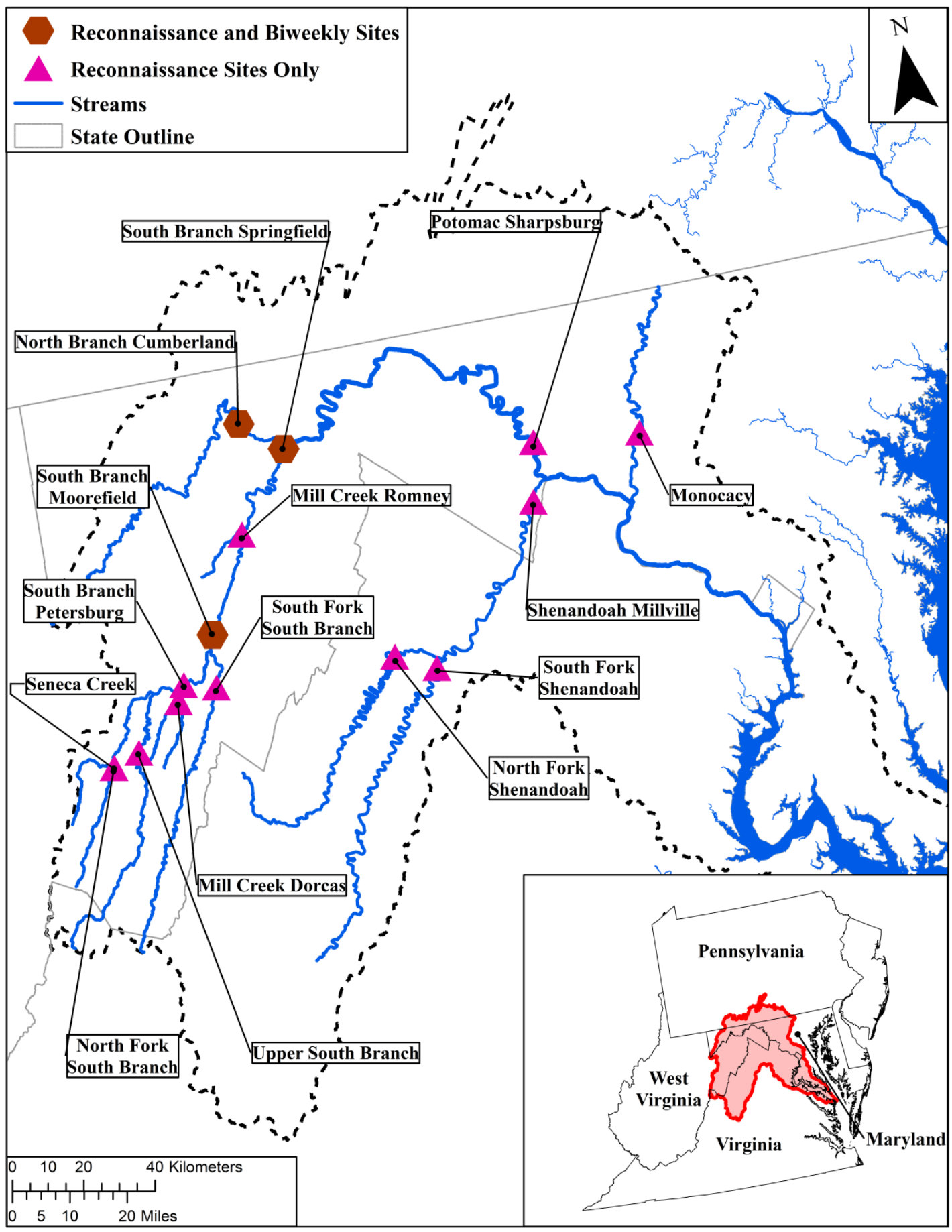


Figure 2. The gray line and circles represents the standard curve from the Abraxis Inc. kit No.

$520011 \pm$ one standard deviation about the mean optical density. The black squares represent the mean Leetown MC-LR standards \pm one standard deviation about the mean optical density on the same plate.

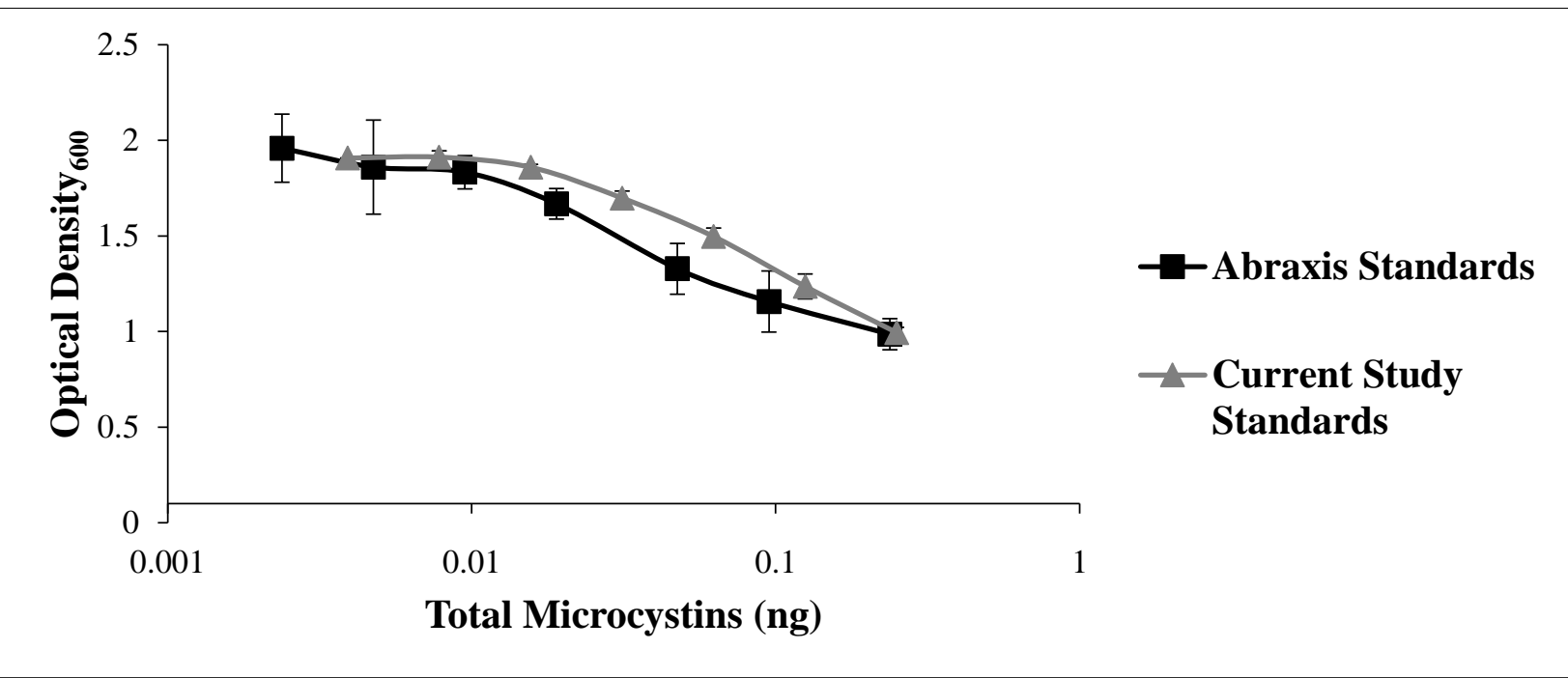


Figure 3. The gray line and circles represents the standard curve from the Abraxis Inc. kit No. 520011as a function of the optical density. The black circles and line represent the mean Leetown MC-LR standards as a function of the mean optical density from 20 randomly selected assay plates.

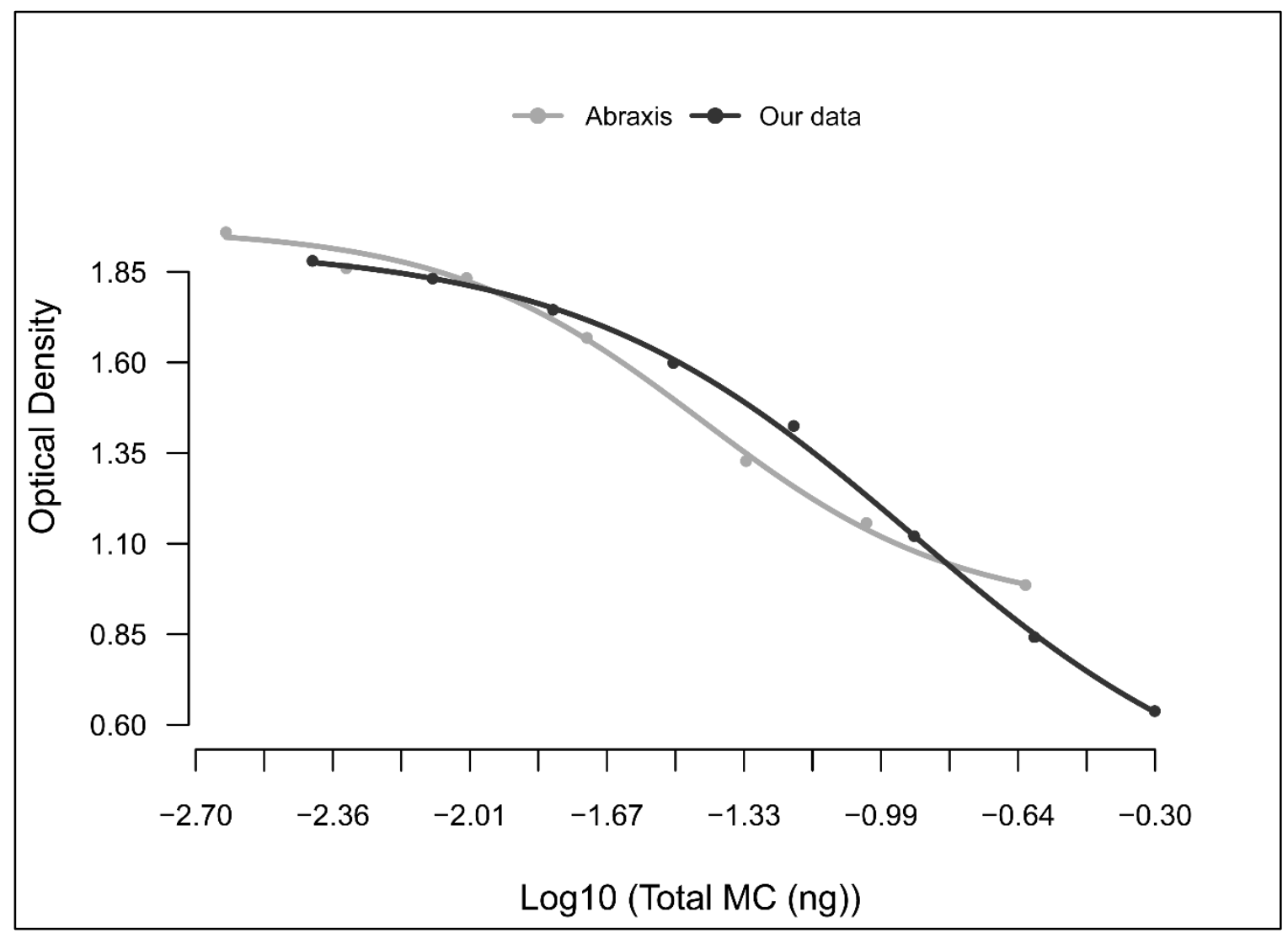


Tables

Table 1. A summary of the cyanobacteria richness at the Shenandoah River and South Branch

Potomac watersheds. Samples were collected opportunistically between April 5, 2010 and June

7, 2013. Identification was performed by GreenWater Laboratories, Palatka, Florida.

\begin{tabular}{|c|c|c|c|c|}
\hline Watershed & Community & Classification & Species & Identification \\
\hline Shenandoah & Periphyton & Merismopedia & glauca & Pre-2013 \\
\hline Shenandoah & Periphyton & Merismopedia & punctata & Pre-2013 \\
\hline Shenandoah & Periphyton & Oscillatoria & spp. & Pre-2013 \\
\hline Shenandoah & Periphyton & Phormidium & cf. retzii & Pre-2013 \\
\hline Shenandoah & Periphyton & Phormidium & spp. & Pre-2013 \\
\hline South Branch & Pelagic & Aphanocapsa & spp. & Pre-2013 \\
\hline South Branch & Pelagic & cf. Aphanocapsa & spp. & Pre-2013 \\
\hline South Branch & Pelagic & Coelomoron & pusillum & Pre-2013 \\
\hline South Branch & Pelagic & Cyanogranis & ferruginea & Pre-2013 \\
\hline South Branch & Pelagic & cyanophyte cell pair & spp. & Pre-2013 \\
\hline South Branch & Pelagic & cyanophyte filament & spp. & Pre-2013 \\
\hline South Branch & Pelagic & cyanophyte unicell, & spp. & Pre-2013 \\
\hline South Branch & Pelagic & cyanophyte unicell, & spp. & Pre-2013 \\
\hline South Branch & Pelagic & Geitlerinema/Jaaginema & spp. & Pre-2013 \\
\hline South Branch & Pelagic & Komvophoron & spp. & Pre-2013 \\
\hline South Branch & Pelagic & Lyngbya/Oscillatoria & spp. & Pre-2013 \\
\hline South Branch & Pelagic & Lyngbya/Phormidium & spp. & Pre-2013 \\
\hline South Branch & Pelagic & Merismopedia & punctata & Pre-2013 \\
\hline South Branch & Pelagic & Oscillatoria & spp. & Pre-2013 \\
\hline South Branch & Pelagic & Phormidium & spp. & Pre-2013 \\
\hline South Branch & Pelagic & Pseudanabaena & spp. & Pre-2013 \\
\hline South Branch & Pelagic & Synechococcus & spp. & Pre-2013 \\
\hline South Branch & Periphyton & cyanophyte filament & spp. & Pre-2013 \\
\hline South Branch & Periphyton & Heteroleibleinia & spp. & Pre-2013 \\
\hline South Branch & Periphyton & Leptolyngbya & spp. & Pre-2013 and \\
\hline South Branch & Periphyton & Merismopedia & glauca & Pre-2013 \\
\hline South Branch & Periphyton & Merismopedia & punctata & Pre-2013 \\
\hline South Branch & Periphyton & Microcoleus & cf. autumnale & Pre-2013 and \\
\hline South Branch & Periphyton & Oscillatoria & princeps & Pre-2013 \\
\hline South Branch & Periphyton & Oscillatoria/Phormidium & spp. & Pre-2013 \\
\hline
\end{tabular}




\begin{tabular}{|c|c|c|c|c|} 
Watershed & Community & Genus & Species & Identification \\
\hline South Branch & Periphyton & Phormidium & autumnale/favosum & Pre-2013 \\
\hline South Branch & Periphyton & Phormidium & cf. amoenum & Pre-2013 \\
\hline South Branch & Periphyton & Phormidium & formosum & Pre-2013 \\
\hline South Branch & Periphyton & Phormidium & spp. & Pre-2013 and \\
\hline South Branch & Periphyton & Pseudanabaena & spp. & Pre-2013 and \\
\hline South Branch & Periphyton & Snowella & litoralis & Pre-2013 \\
\hline
\end{tabular}


Table 2. Sampling site locations throughout Maryland, West Virginia, and Virginia. Sites are identified by the representation as a reconnaissance and/or biweekly water/periphyton, as well as fish sampling location.

\begin{tabular}{|c|c|c|c|c|c|c|c|}
\hline Basin & Site Name & $\begin{array}{c}\text { Site } \\
\text { Abbreviation }\end{array}$ & Latitude & Longitude & $\begin{array}{c}\text { Reconnaissance } \\
\text { Site }\end{array}$ & $\begin{array}{l}\text { Biweekly } \\
\text { Site }\end{array}$ & $\begin{array}{c}\text { Fish } \\
\text { Sampling } \\
\text { Site } \\
\end{array}$ \\
\hline $\begin{array}{l}\text { Monocacy } \\
\text { River }\end{array}$ & $\begin{array}{c}\text { Monocacy } \\
\text { River near } \\
\text { Mouth near } \\
\text { Frederick, } \\
\text { MD }\end{array}$ & Monocacy & 39.38778841 & -77.37984832 & $\mathrm{X}$ & & $\mathrm{X}$ \\
\hline $\begin{array}{l}\text { North } \\
\text { Branch of } \\
\text { the Potomac } \\
\text { River }\end{array}$ & $\begin{array}{l}\text { Mainstem of } \\
\text { the North } \\
\text { Branch at } \\
\text { Cumberland, } \\
\text { MD }\end{array}$ & $\begin{array}{l}\text { North Branch } \\
\text { Cumberland }\end{array}$ & 39.58690227 & -78.73752192 & $\mathrm{X}$ & $\mathrm{X}$ & $\mathrm{X}$ \\
\hline $\begin{array}{l}\text { Potomac } \\
\text { River }\end{array}$ & $\begin{array}{c}\text { Mainstem of } \\
\text { the Potomac } \\
\text { River near } \\
\text { Sharpsburg, } \\
\text { MD }\end{array}$ & $\begin{array}{l}\text { Potomac } \\
\text { Sharpsburg }\end{array}$ & 39.41430527 & -77.74631932 & $\mathrm{X}$ & & $\mathrm{X}$ \\
\hline \multirow{5}{*}{$\begin{array}{l}\text { South } \\
\text { Branch of } \\
\text { the Potomac } \\
\text { River }\end{array}$} & $\begin{array}{l}\text { North Fork } \\
\text { of the South } \\
\text { Branch at } \\
\text { Seneca } \\
\text { Rocks, WV }\end{array}$ & $\begin{array}{c}\text { North Fork } \\
\text { South Branch }\end{array}$ & 38.83389380 & -79.37185151 & $\mathrm{X}$ & & \\
\hline & $\begin{array}{c}\text { South Fork } \\
\text { of the South } \\
\text { Branch near } \\
\text { Moorefield, } \\
\text { WV }\end{array}$ & $\begin{array}{c}\text { South Fork } \\
\text { South Branch }\end{array}$ & 38.97944841 & -78.97721032 & $\mathrm{X}$ & & \\
\hline & $\begin{array}{l}\text { Mainstem of } \\
\text { the South } \\
\text { Branch at } \\
\text { Petersburg, } \\
\text { WV }\end{array}$ & $\begin{array}{l}\text { South Branch } \\
\text { Petersburg }\end{array}$ & 38.99917201 & -79.08622612 & $\mathrm{X}$ & & $\mathrm{X}$ \\
\hline & $\begin{array}{l}\text { Mainstem of } \\
\text { the South } \\
\text { Branch near } \\
\text { Moorefield, } \\
\text { WV }\end{array}$ & $\begin{array}{l}\text { South Branch } \\
\text { Moorefield }\end{array}$ & 39.10406921 & -78.95770572 & $X$ & $\mathrm{X}$ & $\mathrm{X}$ \\
\hline & $\begin{array}{c}\text { Upper } \\
\text { Mainstem of } \\
\text { the South } \\
\text { Branch }\end{array}$ & $\begin{array}{l}\text { Upper South } \\
\text { Branch }\end{array}$ & 38.85888361 & -79.27907259 & $\mathrm{X}$ & & \\
\hline
\end{tabular}




\begin{tabular}{|c|c|c|c|c|c|c|c|}
\hline Basin & Site Name & $\begin{array}{c}\text { Site } \\
\text { Abbreviation }\end{array}$ & Latitude & Longitude & $\begin{array}{c}\text { Reconnaissance } \\
\text { Site }\end{array}$ & $\begin{array}{c}\text { Biweekly } \\
\text { Site }\end{array}$ & $\begin{array}{c}\text { Fish } \\
\text { Sampling } \\
\text { Site }\end{array}$ \\
\hline \multirow{4}{*}{$\begin{array}{l}\text { South } \\
\text { Branch of } \\
\text { the Potomac } \\
\text { River }\end{array}$} & $\begin{array}{l}\text { Mainstem of } \\
\text { the South } \\
\text { Branch near } \\
\text { Mouth near } \\
\text { Springfield, } \\
\text { WV }\end{array}$ & $\begin{array}{l}\text { South Branch } \\
\text { Springfield }\end{array}$ & 39.50934621 & -78.60014072 & $\mathrm{X}$ & $\mathrm{X}$ & \\
\hline & $\begin{array}{c}\text { Mill Creek } \\
\text { near Dorcas, } \\
\text { WV }\end{array}$ & $\begin{array}{l}\text { Mill Creek } \\
\text { Dorcas }\end{array}$ & 38.96181921 & -79.11440952 & $\mathrm{X}$ & & \\
\hline & $\begin{array}{c}\text { Mill Creek } \\
\text { near } \\
\text { Romney, } \\
\text { WV }\end{array}$ & $\begin{array}{l}\text { Mill Creek } \\
\text { Romney }\end{array}$ & 39.32716127 & -78.79627972 & $\mathrm{X}$ & & \\
\hline & $\begin{array}{c}\text { Seneca } \\
\text { Creek near } \\
\text { Seneca } \\
\text { Rocks, WV } \\
\end{array}$ & Seneca Creek & 38.83423291 & -79.37175894 & $\mathrm{X}$ & & \\
\hline $\begin{array}{l}\text { North Fork } \\
\text { of the } \\
\text { Shenandoah } \\
\text { River }\end{array}$ & $\begin{array}{l}\text { North Fork } \\
\text { of the } \\
\text { Shenandoah } \\
\text { River at } \\
\text { Strasburg, } \\
\text { VA }\end{array}$ & $\begin{array}{l}\text { North Fork } \\
\text { Shenandoah }\end{array}$ & 38.97431587 & -78.35507539 & $\mathrm{X}$ & & \\
\hline $\begin{array}{l}\text { South Fork } \\
\text { of the } \\
\text { Shenandoah } \\
\text { River }\end{array}$ & $\begin{array}{l}\text { South Fork } \\
\text { of the } \\
\text { Shenandoah } \\
\text { River at } \\
\text { Front Royal, } \\
\text { VA } \\
\end{array}$ & $\begin{array}{l}\text { South Fork } \\
\text { Shenandoah }\end{array}$ & 38.92916661 & -78.21976819 & $\mathrm{X}$ & & \\
\hline $\begin{array}{l}\text { Shenandoah } \\
\text { River }\end{array}$ & $\begin{array}{c}\text { Shenandoah } \\
\text { River at } \\
\text { Millville, } \\
\text { WV }\end{array}$ & $\begin{array}{l}\text { Shenandoah } \\
\text { Millville }\end{array}$ & 39.27474127 & -77.78561892 & $\mathrm{X}$ & & \\
\hline
\end{tabular}


Table 3. Total MC/NOD concentration $(\mu \mathrm{g} / \mathrm{g})$ based on ELISA or Liquid chromatography/mass spectrometry. All samples were collected in the South Branch Potomac watershed. Analysis was performed by GreenWater Laboratories, Palatka, Florida. Data below the assay detection limit are presented as $\mathrm{BD}$.

\begin{tabular}{|c|c|c|c|c|c|c|c|c|c|c|c|}
\hline \multicolumn{2}{|c|}{} & ELISA $(\mu \mathrm{g} / \mathrm{g})$ & \multicolumn{5}{c|}{ Liquid chromatography/mass spectrometry $(\mu \mathrm{g} / \mathrm{g})$} \\
\hline $\begin{array}{c}\text { Sample } \\
\text { Date }\end{array}$ & $\begin{array}{c}\text { Sample } \\
\text { Medium }\end{array}$ & $\begin{array}{c}\text { Total MC/NOD } \\
\text { Concentration }\end{array}$ & $\begin{array}{c}\text { Total } \\
\text { MC- }\end{array}$ & $\begin{array}{c}\text { Total } \\
\text { MC- }\end{array}$ & $\begin{array}{l}\text { Total } \\
\text { MC- }\end{array}$ & $\begin{array}{c}\text { Total } \\
\text { MC- }\end{array}$ & $\begin{array}{l}\text { Total } \\
\text { MC- }\end{array}$ & $\begin{array}{c}\text { Total } \\
\text { MC- }\end{array}$ & $\begin{array}{l}\text { Total } \\
\text { MC- }\end{array}$ & $\begin{array}{c}\text { Total } \\
\text { NOD }\end{array}$ \\
\hline $1 / 19 / 2013$ & Periphyton & 0.03 & BD & BD & BD & BD & BD & BD & BD & BD \\
\hline $4 / 8 / 2013$ & Periphyton & 0.16 & BD & BD & BD & BD & BD & BD & BD & BD \\
\hline $7 / 19 / 2013$ & SMB Liver & 0.02 & - & - & - & - & - & - & - & - \\
\hline $7 / 19 / 2013$ & SMB Liver & 0.03 & - & - & - & - & - & - & - & - \\
\hline
\end{tabular}


Table 4. Comparison of the ELISA results between the current study and Abraxis kit. Standard deviation for each sample are presented as SD.

\begin{tabular}{|c|c|c|c|c|}
\hline & \multicolumn{2}{|c|}{ Current Study } & \multicolumn{2}{|l|}{ Abraxis } \\
\hline & $\begin{array}{c}\text { Total MC/NOD } \\
(\mathrm{ng} / \mathrm{L})\end{array}$ & SD & $\begin{array}{c}\text { Total MC/NOD } \\
(\mathrm{ng} / \mathrm{L})\end{array}$ & SD \\
\hline $\begin{array}{c}\text { Filtered Water } \\
\text { Sample } 1\end{array}$ & 3.023 & 1.039 & 4.467 & 0.579 \\
\hline $\begin{array}{c}\text { Filtered Water } \\
\text { Sample } 2 \\
\end{array}$ & 75.189 & 0.311 & 35.971 & 0.147 \\
\hline $\begin{array}{c}\text { Filtered Water } \\
\text { Sample } 3\end{array}$ & 164.773 & 19.645 & 95.033 & 18.201 \\
\hline $\begin{array}{c}\text { Filtered Water } \\
\text { Sample } 4 \\
\end{array}$ & 114.572 & 4.206 & 56.920 & 2.533 \\
\hline $\begin{array}{l}\text { Filtered Water } \\
\text { Sample } 5\end{array}$ & 50.868 & 5.466 & 25.079 & 2.337 \\
\hline $\begin{array}{c}\text { Filtered Water } \\
\text { Sample } 6\end{array}$ & 238.368 & 2.457 & 203.792 & 5.999 \\
\hline $\begin{array}{l}\text { Filtered Water } \\
\text { Sample } 7\end{array}$ & 175.766 & 23.896 & 106.460 & 24.895 \\
\hline $\begin{array}{c}\text { Filtered Water } \\
\text { Sample } 8\end{array}$ & 165.294 & 13.486 & 95.046 & 12.525 \\
\hline $\begin{array}{l}\text { Filtered Water } \\
\text { Sample } 9 \\
\end{array}$ & 116.609 & 22.679 & 58.708 & 13.918 \\
\hline $\begin{array}{l}\text { Filtered Water } \\
\text { Sample } 10 \\
\end{array}$ & 238.975 & 12.545 & 206.968 & 31.168 \\
\hline $\begin{array}{c}\text { Filtered Water } \\
\text { Sample } 11\end{array}$ & 78.195 & 10.965 & 37.480 & 5.274 \\
\hline $\begin{array}{c}\text { Unfiltered Water } \\
\text { Sample } 1\end{array}$ & 478.321 & 22.304 & $\mathrm{AQ}$ & - \\
\hline $\begin{array}{c}\text { Unfiltered Water } \\
\text { Sample } 2 \\
\end{array}$ & 146.865 & 1.389 & 78.980 & 1.082 \\
\hline $\begin{array}{c}\text { Unfiltered Water } \\
\text { Sample } 3\end{array}$ & 331.051 & 25.260 & $\mathrm{AQ}$ & - \\
\hline $\begin{array}{c}\text { Unfiltered Water } \\
\text { Sample } 4\end{array}$ & 526.330 & 33.445 & $\mathrm{AQ}$ & - \\
\hline
\end{tabular}




\begin{tabular}{|c|c|c|c|c|}
\hline & \multicolumn{2}{|c|}{ Current Study } & \multicolumn{2}{|c|}{ Abraxis } \\
\hline & $\begin{array}{c}\text { Total MC/NOD } \\
(\mathrm{ng} / \mathrm{L})\end{array}$ & SD & $\begin{array}{c}\text { Total MC/NOD } \\
(\mathrm{ng} / \mathrm{L})\end{array}$ & SD \\
\hline $\begin{array}{c}\text { Unfiltered Water } \\
\text { Sample } 5\end{array}$ & 67.048 & 11.170 & 32.258 & 5.089 \\
\hline $\begin{array}{l}\text { Unfiltered Water } \\
\text { Sample } 6\end{array}$ & 167.158 & 2.844 & 96.387 & 2.685 \\
\hline $\begin{array}{c}\text { Unfiltered Water } \\
\text { Sample } 7\end{array}$ & 249.947 & 0.832 & 235.274 & 2.529 \\
\hline $\begin{array}{c}\text { Unfiltered Water } \\
\text { Sample } 8\end{array}$ & 252.505 & 10.346 & 245.029 & 33.331 \\
\hline $\begin{array}{l}\text { Unfiltered Water } \\
\text { Sample } 9\end{array}$ & 230.439 & 9.677 & 186.467 & 20.695 \\
\hline $\begin{array}{c}\text { Unfiltered Water } \\
\text { Sample } 10\end{array}$ & 365.086 & 17.122 & AQ & - \\
\hline \multirow[t]{2}{*}{$\begin{array}{c}\text { Unfiltered Water } \\
\text { Sample } 11\end{array}$} & 268.937 & 64.638 & 502.192 & 468.182 \\
\hline & $\begin{array}{c}\text { Total MC/NOD } \\
(\mathrm{ng} / \mathrm{g})\end{array}$ & SD & $\begin{array}{c}\text { Total MC/NOD } \\
(\mathrm{ng} / \mathrm{g})\end{array}$ & SD \\
\hline $\begin{array}{c}\text { Periphyton Sample } \\
1\end{array}$ & $\mathrm{BD}$ & 0.000 & 14.417 & 0.005 \\
\hline $\begin{array}{c}\text { Periphyton Sample } \\
2 \\
\end{array}$ & 1.135 & 0.584 & 15.352 & 1.104 \\
\hline $\begin{array}{c}\text { Periphyton Sample } \\
3 \\
\end{array}$ & 10.392 & 4.710 & 51.156 & 0.961 \\
\hline $\begin{array}{c}\text { Periphyton Sample } \\
4\end{array}$ & 222.618 & 4.448 & 69.765 & 14.476 \\
\hline $\begin{array}{c}\text { Periphyton Sample } \\
5 \\
\end{array}$ & 125.070 & 75.553 & 747.048 & 541.871 \\
\hline $\begin{array}{l}\text { SMB Liver } \\
\text { Sample } 1 \\
\end{array}$ & $\mathrm{BD}$ & 0.000 & 3.240 & 0.045 \\
\hline $\begin{array}{l}\text { SMB Liver } \\
\text { Sample } 2 \\
\end{array}$ & 1.750 & 0.515 & 0.277 & 0.014 \\
\hline $\begin{array}{l}\text { SMB Liver } \\
\text { Sample } 3\end{array}$ & 4.858 & 0.177 & 1.325 & 0.040 \\
\hline $\begin{array}{c}\text { SMB Liver } \\
\text { Sample } 4\end{array}$ & 34.940 & 2.085 & 104.753 & 12.005 \\
\hline
\end{tabular}




\begin{tabular}{|c|c|c|c|c|}
\hline & $\begin{array}{c}\text { Total MC/NOD } \\
(\mathbf{n g} / \mathbf{g})\end{array}$ & SD & $\begin{array}{c}\text { Total MC/NOD } \\
(\mathbf{n g} / \mathbf{g})\end{array}$ & SD \\
\hline $\begin{array}{c}\text { SMB Liver } \\
\text { Sample 5 }\end{array}$ & 18.263 & 3.632 & 38.604 & 2.391 \\
\hline $\begin{array}{c}\text { GRH Liver } \\
\text { Sample 1 }\end{array}$ & BD & 0.000 & 27.239 & 4.501 \\
\hline $\begin{array}{c}\text { GRH Liver } \\
\text { Sample 2 }\end{array}$ & 0.955 & 0.402 & 4.635 & 0.062 \\
\hline $\begin{array}{c}\text { GRH Liver } \\
\text { Sample 3 }\end{array}$ & 1.237 & 0.083 & 1.478 & 0.064 \\
\hline $\begin{array}{c}\text { GRH Liver } \\
\text { Sample 4 }\end{array}$ & 6.624 & 1.808 & 1.427 & 0.052 \\
\hline $\begin{array}{c}\text { GRH Liver } \\
\text { Sample 5 }\end{array}$ & 14.181 & 3.756 & 20.519 & 5.515 \\
\hline
\end{tabular}


Table 5. Summary of total microcystins/nodularins in each sample type grouped by season and year. Sample size is presented as $n$ and standard error is presented as SE.

\begin{tabular}{|c|c|c|c|c|c|c|c|c|}
\hline \multirow{2}{*}{ Site Name } & \multirow[b]{2}{*}{$\begin{array}{c}\text { Season } \\
\text { and Year }\end{array}$} & \multirow[b]{2}{*}{$n$} & \multicolumn{2}{|c|}{ Filtered Water } & \multicolumn{2}{|c|}{ Unfiltered Water } & \multicolumn{2}{|c|}{ Periphyton } \\
\hline & & & $\begin{array}{c}\text { Total } \\
\text { MC/NOD } \\
(\text { ng/L) } \\
\end{array}$ & SE & $\begin{array}{c}\text { Total } \\
\text { MC/NOD } \\
(\mathrm{ng} / \mathrm{L}) \\
\end{array}$ & SE & $\begin{array}{c}\text { Total } \\
\text { MC/NOD } \\
(\mathbf{n g} / \mathrm{g}) \\
\end{array}$ & SE \\
\hline \multirow{5}{*}{$\begin{array}{l}\text { Monocacy River near } \\
\text { Mouth near } \\
\text { Frederick, MD }\end{array}$} & $\begin{array}{l}2013 \\
\text { Summer }\end{array}$ & 2 & 5.39 & 2.26 & 16.66 & 0.29 & 0.05 & 0.02 \\
\hline & $\begin{array}{l}2013 \\
\text { Autumn }\end{array}$ & 2 & 6.19 & 1.19 & 10.76 & 5.34 & 1.56 & 1.49 \\
\hline & $\begin{array}{l}2014 \\
\text { Winter } \\
\end{array}$ & 3 & 4.47 & 0.86 & 5.32 & 1.06 & 2.70 & 1.40 \\
\hline & $\begin{array}{l}2014 \\
\text { Spring } \\
\end{array}$ & 3 & 3.68 & 0.94 & 3.48 & 0.18 & 2.63 & 1.21 \\
\hline & $\begin{array}{l}2014 \\
\text { Summer } \\
\end{array}$ & 1 & 2.90 & NA & 4.72 & NA & 2.54 & NA \\
\hline \multirow{11}{*}{$\begin{array}{l}\text { Mainstem of the } \\
\text { North Branch at } \\
\text { Cumberland, MD }\end{array}$} & $\begin{array}{l}2013 \\
\text { Summer }\end{array}$ & 3 & 9.18 & 2.86 & 27.33 & 16.83 & 1.60 & 0.61 \\
\hline & $\begin{array}{l}2013 \\
\text { Autumn }\end{array}$ & 2 & 8.97 & 1.75 & 11.03 & 0.13 & 1.40 & 0.35 \\
\hline & $\begin{array}{l}2014 \\
\text { Winter }\end{array}$ & 3 & 5.04 & 1.17 & 3.33 & 0.33 & 2.01 & 0.84 \\
\hline & $\begin{array}{l}2014 \\
\text { Spring } \\
\end{array}$ & 3 & 3.72 & 0.92 & 3.34 & 0.06 & 4.18 & 2.77 \\
\hline & $\begin{array}{l}2014 \\
\text { Summer }\end{array}$ & 7 & 6.43 & 1.95 & 7.70 & 1.48 & 1.06 & 0.18 \\
\hline & $\begin{array}{l}2014 \\
\text { Autumn }\end{array}$ & 6 & 6.25 & 1.59 & 7.91 & 3.30 & 10.37 & 4.06 \\
\hline & $\begin{array}{l}2015 \\
\text { Winter } \\
\end{array}$ & 7 & 3.76 & 0.25 & 3.41 & 0.53 & 2.78 & 0.89 \\
\hline & $\begin{array}{l}2015 \\
\text { Spring }\end{array}$ & 6 & 2.93 & 0.47 & 3.10 & 0.90 & 1.63 & 0.78 \\
\hline & $\begin{array}{l}2015 \\
\text { Summer }\end{array}$ & 7 & 6.22 & 1.36 & 7.47 & 1.92 & 1.81 & 0.80 \\
\hline & $\begin{array}{l}2015 \\
\text { Autumn }\end{array}$ & 7 & 3.15 & 1.33 & 8.45 & 1.86 & 5.46 & 1.50 \\
\hline & $\begin{array}{l}2016 \\
\text { Winter }\end{array}$ & 1 & 2.05 & NA & 6.47 & NA & 2.38 & NA \\
\hline
\end{tabular}




\begin{tabular}{|c|c|c|c|c|c|c|c|c|}
\hline \multirow{2}{*}{ Site Name } & \multirow[b]{2}{*}{$\begin{array}{c}\text { Season } \\
\text { and Year }\end{array}$} & \multirow[b]{2}{*}{$n$} & \multicolumn{2}{|c|}{ Filtered Water } & \multicolumn{2}{|c|}{ Unfiltered Water } & \multicolumn{2}{|c|}{ Periphyton } \\
\hline & & & $\begin{array}{c}\text { Total } \\
\text { MC/NOD } \\
(\text { ng/L) } \\
\end{array}$ & SE & $\begin{array}{c}\text { Total } \\
\text { MC/NOD } \\
(\text { ng/L) } \\
\end{array}$ & SE & $\begin{array}{c}\text { Total } \\
\text { MC/NOD } \\
\text { (ng/g) } \\
\end{array}$ & SE \\
\hline \multirow{5}{*}{$\begin{array}{l}\text { Mainstem of the } \\
\text { Potomac River near } \\
\text { Sharpsburg, MD }\end{array}$} & $\begin{array}{l}2013 \\
\text { Summer }\end{array}$ & 2 & 3.15 & 0.02 & 4.52 & 2.09 & 0.56 & 0.52 \\
\hline & $\begin{array}{l}2013 \\
\text { Autumn } \\
\end{array}$ & 2 & 7.89 & 2.89 & 4.86 & 1.54 & 1.26 & 0.96 \\
\hline & $\begin{array}{l}2014 \\
\text { Winter }\end{array}$ & 3 & 5.09 & 0.24 & 3.29 & 0.74 & 1.99 & 1.31 \\
\hline & $\begin{array}{l}2014 \\
\text { Spring }\end{array}$ & 3 & 4.32 & 0.85 & 6.00 & 1.75 & 3.50 & 1.22 \\
\hline & $\begin{array}{l}2014 \\
\text { Summer } \\
\end{array}$ & 1 & 4.73 & NA & 4.62 & NA & 0.07 & NA \\
\hline \multirow{5}{*}{$\begin{array}{l}\text { North Fork of the } \\
\text { South Branch at } \\
\text { Seneca Rocks, WV }\end{array}$} & $\begin{array}{l}2013 \\
\text { Summer } \\
\end{array}$ & 2 & 18.60 & 2.09 & 25.75 & 18.89 & 5.52 & 5.33 \\
\hline & $\begin{array}{l}2013 \\
\text { Autumn }\end{array}$ & 2 & 9.17 & 3.53 & 9.88 & 4.99 & 0.46 & 0.41 \\
\hline & $\begin{array}{l}2014 \\
\text { Winter } \\
\end{array}$ & 3 & 5.41 & 0.68 & 4.35 & 0.27 & 2.43 & 1.93 \\
\hline & $\begin{array}{l}2014 \\
\text { Spring }\end{array}$ & 3 & 4.47 & 0.71 & 4.30 & 0.53 & 5.68 & 2.64 \\
\hline & $\begin{array}{l}2014 \\
\text { Summer } \\
\end{array}$ & 1 & 11.21 & NA & 7.51 & NA & 3.76 & NA \\
\hline \multirow{5}{*}{$\begin{array}{l}\text { South Fork of the } \\
\text { South Branch near } \\
\text { Moorefield, WV }\end{array}$} & $\begin{array}{l}2013 \\
\text { Summer }\end{array}$ & 2 & 7.15 & 4.02 & 22.85 & 12.44 & 4.23 & 4.18 \\
\hline & $\begin{array}{l}2013 \\
\text { Autumn } \\
\end{array}$ & 2 & 7.17 & 2.17 & 4.48 & 0.57 & 0.47 & 0.07 \\
\hline & $\begin{array}{l}2014 \\
\text { Winter }\end{array}$ & 3 & 4.96 & 1.25 & 4.78 & 1.33 & 12.01 & 4.51 \\
\hline & $\begin{array}{l}2014 \\
\text { Spring } \\
\end{array}$ & 3 & 2.53 & 0.22 & 3.30 & 0.87 & 1.09 & 0.45 \\
\hline & $\begin{array}{l}2014 \\
\text { Summer } \\
\end{array}$ & 1 & 5.69 & NA & 9.12 & NA & 5.18 & NA \\
\hline
\end{tabular}




\begin{tabular}{|c|c|c|c|c|c|c|c|c|}
\hline \multirow{2}{*}{ Site Name } & \multirow[b]{2}{*}{$\begin{array}{c}\text { Season } \\
\text { and Year }\end{array}$} & \multirow[b]{2}{*}{$n$} & \multicolumn{2}{|c|}{ Filtered Water } & \multicolumn{2}{|c|}{ Unfiltered Water } & \multicolumn{2}{|c|}{ Periphyton } \\
\hline & & & $\begin{array}{c}\text { Total } \\
\text { MC/NOD } \\
(\mathbf{n g} / \mathbf{L})\end{array}$ & SE & $\begin{array}{c}\text { Total } \\
\text { MC/NOD } \\
(\mathbf{n g} / \mathbf{L})\end{array}$ & SE & $\begin{array}{c}\text { Total } \\
\text { MC/NOD } \\
\text { (ng/g) }\end{array}$ & SE \\
\hline \multirow{5}{*}{$\begin{array}{l}\text { Upper Mainstem of } \\
\text { the South Branch }\end{array}$} & $\begin{array}{l}2013 \\
\text { Summer }\end{array}$ & 2 & 8.74 & 2.60 & 15.26 & 5.83 & 0.61 & 0.55 \\
\hline & $\begin{array}{l}2013 \\
\text { Autumn }\end{array}$ & 2 & 4.70 & 0.31 & 15.97 & 5.43 & 1.93 & 0.31 \\
\hline & $\begin{array}{l}2014 \\
\text { Winter }\end{array}$ & 3 & 5.68 & 0.59 & 5.33 & 2.02 & 5.48 & 2.53 \\
\hline & $\begin{array}{l}2014 \\
\text { Spring }\end{array}$ & 3 & 4.28 & 0.82 & 4.33 & 1.65 & 2.10 & 1.31 \\
\hline & $\begin{array}{l}2014 \\
\text { Summer } \\
\end{array}$ & 1 & 3.93 & NA & 11.61 & NA & 1.78 & NA \\
\hline \multirow{5}{*}{$\begin{array}{l}\text { Mainstem of the } \\
\text { South Branch at } \\
\text { Petersburg, WV }\end{array}$} & $\begin{array}{l}2013 \\
\text { Summer }\end{array}$ & 2 & 8.42 & 5.38 & 29.32 & 3.72 & 5.97 & 1.84 \\
\hline & $\begin{array}{l}2013 \\
\text { Autumn } \\
\end{array}$ & 2 & 4.87 & 0.14 & 6.50 & 3.18 & 6.72 & 5.10 \\
\hline & $\begin{array}{l}2014 \\
\text { Winter }\end{array}$ & 3 & 5.68 & 0.59 & 3.99 & 0.63 & 2.51 & 0.95 \\
\hline & $\begin{array}{l}2014 \\
\text { Spring } \\
\end{array}$ & 3 & 4.98 & 1.12 & 3.75 & 0.44 & 9.19 & 0.81 \\
\hline & $\begin{array}{l}2014 \\
\text { Summer }\end{array}$ & 2 & 16.28 & 3.27 & 24.98 & 9.68 & 3.71 & 1.59 \\
\hline \multirow{9}{*}{$\begin{array}{l}\text { Mainstem of the } \\
\text { South Branch near } \\
\text { Moorefield, WV }\end{array}$} & $\begin{array}{l}2013 \\
\text { Summer } \\
\end{array}$ & 2 & 9.24 & 6.20 & 30.17 & 1.84 & 5.17 & 2.92 \\
\hline & $\begin{array}{l}2013 \\
\text { Autumn } \\
\end{array}$ & 2 & 11.45 & 4.69 & 11.10 & 6.98 & 111.62 & 111.00 \\
\hline & $\begin{array}{l}2014 \\
\text { Winter }\end{array}$ & 3 & 5.21 & 1.01 & 3.65 & 0.22 & 2.98 & 1.30 \\
\hline & $\begin{array}{l}2014 \\
\text { Spring }\end{array}$ & 4 & 3.94 & 0.48 & 4.81 & 0.19 & 0.97 & 0.79 \\
\hline & $\begin{array}{l}2014 \\
\text { Summer } \\
\end{array}$ & 8 & 23.15 & 5.05 & 39.35 & 11.09 & 2.25 & 0.73 \\
\hline & $\begin{array}{l}2014 \\
\text { Autumn }\end{array}$ & 6 & 9.86 & 3.66 & 11.75 & 3.44 & 23.49 & 20.37 \\
\hline & $\begin{array}{l}2015 \\
\text { Winter }\end{array}$ & 7 & 4.56 & 0.56 & 5.67 & 1.33 & 2.81 & 1.01 \\
\hline & $\begin{array}{l}2015 \\
\text { Spring }\end{array}$ & 6 & 2.66 & 0.32 & 4.32 & 1.32 & 1.25 & 0.91 \\
\hline & $\begin{array}{l}2015 \\
\text { Summer }\end{array}$ & 7 & 9.67 & 2.11 & 13.93 & 2.37 & 3.11 & 1.15 \\
\hline
\end{tabular}




\begin{tabular}{|c|c|c|c|c|c|c|c|c|}
\hline \multirow{2}{*}{ Site Name } & \multirow[b]{2}{*}{$\begin{array}{c}\text { Season } \\
\text { and Year }\end{array}$} & \multirow[b]{2}{*}{$n$} & \multicolumn{2}{|c|}{ Filtered Water } & \multicolumn{2}{|c|}{ Unfiltered Water } & \multicolumn{2}{|c|}{ Periphyton } \\
\hline & & & $\begin{array}{c}\text { Total } \\
\text { MC/NOD } \\
(\text { ng/L) } \\
\end{array}$ & SE & $\begin{array}{c}\text { Total } \\
\text { MC/NOD } \\
(\mathrm{ng} / \mathrm{L}) \\
\end{array}$ & SE & $\begin{array}{c}\text { Total } \\
\text { MC/NOD } \\
(\mathbf{n g} / \mathrm{g}) \\
\end{array}$ & SE \\
\hline \multirow{2}{*}{$\begin{array}{l}\text { Mainstem of the } \\
\text { South Branch near } \\
\text { Moorefield, WV }\end{array}$} & $\begin{array}{l}2015 \\
\text { Autumn }\end{array}$ & 7 & 4.05 & 1.28 & 9.32 & 2.74 & 3.61 & 1.23 \\
\hline & $\begin{array}{l}2016 \\
\text { Winter }\end{array}$ & 1 & 8.06 & NA & 23.24 & NA & 1.64 & NA \\
\hline \multirow{11}{*}{$\begin{array}{l}\text { Mainstem of the } \\
\text { South Branch near } \\
\text { Mouth near } \\
\text { Springfield, WV }\end{array}$} & $\begin{array}{l}2013 \\
\text { Summer }\end{array}$ & 2 & 12.34 & 7.92 & 26.92 & 0.24 & 0.04 & 0.00 \\
\hline & $\begin{array}{l}2013 \\
\text { Autumn }\end{array}$ & 2 & 10.45 & 5.27 & 19.80 & 4.12 & 1.29 & 0.69 \\
\hline & $\begin{array}{l}2014 \\
\text { Winter }\end{array}$ & 3 & 5.97 & 0.63 & 4.30 & 1.63 & 6.56 & 2.61 \\
\hline & $\begin{array}{l}2014 \\
\text { Spring }\end{array}$ & 3 & 4.65 & 1.32 & 6.42 & 3.20 & 4.42 & 2.18 \\
\hline & $\begin{array}{l}2014 \\
\text { Summer }\end{array}$ & 6 & 28.04 & 5.52 & 39.70 & 7.38 & 2.63 & 1.43 \\
\hline & $\begin{array}{l}2014 \\
\text { Autumn } \\
\end{array}$ & 6 & 11.43 & 4.06 & 16.45 & 5.22 & 2.25 & 0.81 \\
\hline & $\begin{array}{l}2015 \\
\text { Winter }\end{array}$ & 7 & 3.61 & 0.17 & 6.16 & 2.48 & 3.99 & 2.30 \\
\hline & $\begin{array}{l}2015 \\
\text { Spring } \\
\end{array}$ & 6 & 6.60 & 2.91 & 7.57 & 2.37 & 0.97 & 0.39 \\
\hline & $\begin{array}{l}2015 \\
\text { Summer }\end{array}$ & 7 & 14.65 & 3.31 & 22.37 & 2.51 & 16.68 & 9.92 \\
\hline & $\begin{array}{l}2015 \\
\text { Autumn }\end{array}$ & 7 & 4.30 & 0.70 & 8.00 & 1.57 & 5.48 & 3.43 \\
\hline & $\begin{array}{l}2016 \\
\text { Winter } \\
\end{array}$ & 1 & 12.19 & NA & 24.01 & NA & 1.97 & NA \\
\hline \multirow{5}{*}{$\begin{array}{l}\text { Mill Creek near } \\
\text { Dorcas, WV }\end{array}$} & $\begin{array}{l}2013 \\
\text { Summer }\end{array}$ & 2 & 5.62 & 2.49 & 10.95 & 8.52 & 0.34 & 0.27 \\
\hline & $\begin{array}{l}2013 \\
\text { Autumn }\end{array}$ & 2 & 5.67 & 2.87 & 8.44 & 5.04 & 3.97 & 3.09 \\
\hline & $\begin{array}{l}2014 \\
\text { Winter }\end{array}$ & 3 & 5.77 & 0.52 & 5.46 & 1.93 & 2.84 & 2.56 \\
\hline & $\begin{array}{l}2014 \\
\text { Spring }\end{array}$ & 3 & 4.67 & 0.70 & 5.36 & 2.06 & 7.54 & 3.51 \\
\hline & $\begin{array}{l}2014 \\
\text { Summer } \\
\end{array}$ & 1 & 4.16 & NA & 4.48 & NA & 0.97 & NA \\
\hline
\end{tabular}




\begin{tabular}{|c|c|c|c|c|c|c|c|c|}
\hline \multirow{2}{*}{ Site Name } & \multirow[b]{2}{*}{$\begin{array}{c}\text { Season } \\
\text { and Year }\end{array}$} & \multirow[b]{2}{*}{$n$} & \multicolumn{2}{|c|}{ Filtered Water } & \multicolumn{2}{|c|}{ Unfiltered Water } & \multicolumn{2}{|c|}{ Periphyton } \\
\hline & & & $\begin{array}{c}\text { Total } \\
\text { MC/NOD } \\
(\text { ng/L) } \\
\end{array}$ & SE & $\begin{array}{c}\text { Total } \\
\text { MC/NOD } \\
(\text { ng/L) } \\
\end{array}$ & SE & $\begin{array}{c}\text { Total } \\
\text { MC/NOD } \\
\text { (ng/g) } \\
\end{array}$ & SE \\
\hline \multirow{5}{*}{$\begin{array}{l}\text { Mill Creek near } \\
\text { Romney, WV }\end{array}$} & $\begin{array}{l}2013 \\
\text { Summer }\end{array}$ & 2 & 12.21 & 5.52 & 30.27 & 13.24 & 0.44 & 0.29 \\
\hline & $\begin{array}{l}2013 \\
\text { Autumn }\end{array}$ & 2 & 3.62 & 0.58 & 8.89 & 3.84 & 1.78 & 1.13 \\
\hline & $\begin{array}{l}2014 \\
\text { Winter }\end{array}$ & 3 & 5.77 & 0.52 & 5.87 & 2.34 & 2.89 & 1.03 \\
\hline & $\begin{array}{l}2014 \\
\text { Spring }\end{array}$ & 3 & 3.72 & 0.92 & 3.34 & 0.06 & 1.03 & 0.48 \\
\hline & $\begin{array}{l}2014 \\
\text { Summer } \\
\end{array}$ & 1 & 39.46 & NA & 2.59 & NA & 6.51 & NA \\
\hline \multirow{5}{*}{$\begin{array}{l}\text { Seneca Creek near } \\
\text { Seneca Rocks, WV }\end{array}$} & $\begin{array}{l}2013 \\
\text { Summer } \\
\end{array}$ & 2 & 10.77 & 1.30 & 26.52 & 0.19 & 0.57 & 0.49 \\
\hline & $\begin{array}{l}2013 \\
\text { Autumn }\end{array}$ & 2 & 4.53 & 1.49 & 3.31 & 0.47 & 0.91 & 0.25 \\
\hline & $\begin{array}{l}2014 \\
\text { Winter } \\
\end{array}$ & 3 & 5.57 & 1.52 & 5.28 & 0.72 & 6.38 & 2.78 \\
\hline & $\begin{array}{l}2014 \\
\text { Spring }\end{array}$ & 3 & 2.69 & 0.10 & 3.76 & 1.23 & 11.38 & 6.29 \\
\hline & $\begin{array}{l}2014 \\
\text { Summer } \\
\end{array}$ & 1 & 5.26 & NA & 9.88 & NA & 2.36 & NA \\
\hline \multirow{5}{*}{$\begin{array}{l}\text { North Fork of the } \\
\text { Shenandoah River at } \\
\text { Strasburg, VA }\end{array}$} & $\begin{array}{l}2013 \\
\text { Summer }\end{array}$ & 2 & 6.06 & 2.93 & 3.96 & 1.53 & 0.17 & 0.11 \\
\hline & $\begin{array}{l}2013 \\
\text { Autumn }\end{array}$ & 2 & 8.14 & 3.14 & 16.65 & 0.32 & 0.87 & 0.84 \\
\hline & $\begin{array}{l}2014 \\
\text { Winter }\end{array}$ & 3 & 6.36 & 0.40 & 8.97 & 5.10 & 3.16 & 1.84 \\
\hline & $\begin{array}{l}2014 \\
\text { Spring } \\
\end{array}$ & 3 & 3.11 & 0.32 & 4.29 & 0.24 & 2.02 & 1.42 \\
\hline & $\begin{array}{l}2014 \\
\text { Summer } \\
\end{array}$ & 1 & 3.90 & NA & 4.39 & NA & 1.08 & NA \\
\hline
\end{tabular}




\begin{tabular}{|c|c|c|c|c|c|c|c|c|}
\hline \multirow{2}{*}{ Site Name } & \multirow[b]{2}{*}{$\begin{array}{c}\text { Season } \\
\text { and Year }\end{array}$} & \multirow[b]{2}{*}{$n$} & \multicolumn{2}{|c|}{ Filtered Water } & \multicolumn{2}{|c|}{ Unfiltered Water } & \multicolumn{2}{|c|}{ Periphyton } \\
\hline & & & $\begin{array}{c}\text { Total } \\
\text { MC/NOD } \\
(\mathbf{n g} / \mathrm{L}) \\
\end{array}$ & SE & $\begin{array}{c}\text { Total } \\
\text { MC/NOD } \\
(\mathrm{ng} / \mathrm{L}) \\
\end{array}$ & SE & $\begin{array}{c}\text { Total } \\
\text { MC/NOD } \\
(\mathbf{n g} / \mathrm{g}) \\
\end{array}$ & SE \\
\hline \multirow{5}{*}{$\begin{array}{l}\text { South Fork of the } \\
\text { Shenandoah River at } \\
\text { Front Royal, VA }\end{array}$} & $\begin{array}{l}2013 \\
\text { Summer }\end{array}$ & 2 & 3.28 & 1.75 & 7.32 & 1.98 & 0.03 & 0.00 \\
\hline & $\begin{array}{l}2013 \\
\text { Autumn }\end{array}$ & 2 & 5.28 & 0.76 & 9.47 & 2.97 & 2.88 & 0.57 \\
\hline & $\begin{array}{l}2014 \\
\text { Winter }\end{array}$ & 3 & 5.36 & 1.40 & 3.51 & 0.36 & 10.72 & 6.71 \\
\hline & $\begin{array}{l}2014 \\
\text { Spring }\end{array}$ & 3 & 2.72 & 0.10 & 3.80 & 0.56 & 3.61 & 3.35 \\
\hline & $\begin{array}{l}2014 \\
\text { Summer } \\
\end{array}$ & 1 & 2.56 & NA & 2.37 & NA & 0.02 & NA \\
\hline \multirow{5}{*}{$\begin{array}{l}\text { Shenandoah River at } \\
\text { Millville, WV }\end{array}$} & $\begin{array}{l}2013 \\
\text { Summer }\end{array}$ & 2 & 7.74 & 0.94 & 13.10 & 3.72 & 0.04 & 0.02 \\
\hline & $\begin{array}{l}2013 \\
\text { Autumn }\end{array}$ & 2 & 4.79 & 0.21 & 5.88 & 3.08 & 53.79 & 52.30 \\
\hline & $\begin{array}{l}2014 \\
\text { Winter } \\
\end{array}$ & 3 & 5.95 & 0.21 & 4.97 & 0.56 & 3.86 & 0.71 \\
\hline & $\begin{array}{l}2014 \\
\text { Spring }\end{array}$ & 3 & 2.55 & 0.08 & 3.00 & 0.20 & 8.45 & 3.73 \\
\hline & $\begin{array}{l}2014 \\
\text { Summer }\end{array}$ & 1 & 6.76 & NA & 2.81 & NA & 1.52 & NA \\
\hline
\end{tabular}


Table 6. Seasonal summary of total microcystins/nodularins in all three mediums pooled among all sampling sites. Sample size is presented as $n$ and standard error is presented as SE.

\begin{tabular}{|c|c|c|c|c|c|c|c|c|}
\hline $\begin{array}{l}\text { Season } \\
\text { and } \\
\text { Year }\end{array}$ & $n$ & $\begin{array}{l}\text { Filtered } \\
\text { Water } \\
(\text { ng/L) }\end{array}$ & $\begin{array}{c}\text { Filtered } \\
\text { Water } \\
\text { SE }\end{array}$ & $\begin{array}{l}\text { Unfiltered } \\
\text { Water } \\
\text { (ng/L) }\end{array}$ & $\begin{array}{l}\text { Unfiltered } \\
\text { Water SE }\end{array}$ & $\begin{array}{c}\text { Significant } \\
\text { Difference } \\
\text { among } \\
\text { Water } \\
\text { Fractions } \\
\end{array}$ & $\begin{array}{c}\text { Periphyton } \\
\text { (ng/g) }\end{array}$ & $\begin{array}{c}\text { Periphyton } \\
\text { SE }\end{array}$ \\
\hline $\begin{array}{c}2013 \\
\text { Summer }\end{array}$ & 31 & 8.54 & 0.99 & 19.65 & 2.54 & $<0.001$ & 1.69 & 0.53 \\
\hline $\begin{array}{c}2013 \\
\text { Autumn }\end{array}$ & 30 & 6.86 & 0.64 & 9.80 & 1.11 & 0.026 & 12.73 & 8.04 \\
\hline $\begin{array}{c}2014 \\
\text { Winter }\end{array}$ & 45 & 5.49 & 0.20 & 4.83 & 0.43 & 0.170 & 4.57 & 0.73 \\
\hline $\begin{array}{c}2014 \\
\text { Spring }\end{array}$ & 46 & 3.74 & 0.20 & 4.23 & 0.30 & 0.176 & 4.44 & 0.73 \\
\hline $\begin{array}{c}2014 \\
\text { Summer }\end{array}$ & 34 & 15.34 & 2.36 & 21.20 & 3.95 & 0.208 & 2.19 & 0.37 \\
\hline $\begin{array}{c}2014 \\
\text { Autumn }\end{array}$ & 18 & 9.18 & 1.86 & 12.04 & 2.37 & 0.349 & 12.04 & 6.85 \\
\hline $\begin{array}{c}2015 \\
\text { Winter }\end{array}$ & 21 & 3.98 & 0.22 & 5.08 & 0.94 & 0.267 & 3.19 & 0.85 \\
\hline $\begin{array}{c}2015 \\
\text { Spring }\end{array}$ & 18 & 4.06 & 1.02 & 5.00 & 1.01 & 0.520 & 1.28 & 0.40 \\
\hline $\begin{array}{c}2015 \\
\text { Summer }\end{array}$ & 21 & 10.18 & 1.52 & 14.59 & 1.85 & 0.073 & 7.20 & 3.51 \\
\hline $\begin{array}{c}2015 \\
\text { Autumn }\end{array}$ & 21 & 3.83 & 0.63 & 8.59 & 1.17 & 0.001 & 4.85 & 1.26 \\
\hline $\begin{array}{c}2016 \\
\text { Winter }\end{array}$ & 3 & 7.43 & 2.94 & 17.91 & 5.72 & NA & 1.99 & 0.21 \\
\hline
\end{tabular}


Table 7. Linear mixed effect model results for total microcystins/nodularins as a function of physical and nutrient explanatory variables among each sample medium and time points.

\begin{tabular}{|c|c|c|c|c|}
\hline \multicolumn{5}{|c|}{ Filtered Water } \\
\hline \multirow{6}{*}{$\begin{array}{l}\text { Initial } 12 \\
\text { Months }\end{array}$} & & Estimate & Adjusted SE & Importance: \\
\hline & (Intercept) & $-1.51 \mathrm{E}-02$ & $1.20 \mathrm{E}-02$ & \\
\hline & $\mathrm{pH}$ & $2.49 \mathrm{E}-03$ & $1.45 \mathrm{E}-03$ & 0.88 \\
\hline & Temperature & $1.38 \mathrm{E}-04$ & $6.07 \mathrm{E}-05$ & 0.94 \\
\hline & Conductivity & $-1.80 \mathrm{E}-06$ & $2.61 \mathrm{E}-06$ & 0.46 \\
\hline & Discharge & $-4.83 \mathrm{E}-08$ & $1.18 \mathrm{E}-07$ & 0.35 \\
\hline \multirow{11}{*}{$\begin{array}{l}\text { Subsequent } \\
16 \text { Months }\end{array}$} & & Estimate & Adjusted SE & Importance: \\
\hline & (Intercept) & $3.34 \mathrm{E}-03$ & $1.24 \mathrm{E}-02$ & \\
\hline & $\mathrm{pH}$ & $-6.00 \mathrm{E}-06$ & $5.95 \mathrm{E}-06$ & 0.25 \\
\hline & Temperature & $5.64 \mathrm{E}-04$ & $1.14 \mathrm{E}-04$ & 1.00 \\
\hline & Conductivity & $-4.23 \mathrm{E}-08$ & $2.72 \mathrm{E}-07$ & 0.63 \\
\hline & Discharge & $-1.75 \mathrm{E}-04$ & $1.47 \mathrm{E}-03$ & 0.26 \\
\hline & & Estimate & Adjusted SE & Importance: \\
\hline & (Intercept) & $-4.64 \mathrm{E}-04$ & $2.37 \mathrm{E}-03$ & \\
\hline & Temperature.C & $6.30 \mathrm{E}-04$ & $1.18 \mathrm{E}-04$ & 1.00 \\
\hline & Water Column Total N & $-9.84 \mathrm{E}-04$ & $1.17 \mathrm{E}-03$ & 0.57 \\
\hline & Water Column Total P & $-9.84 \mathrm{E}-04$ & $3.65 \mathrm{E}-03$ & 0.29 \\
\hline
\end{tabular}

\begin{tabular}{|clrrr|}
\hline \multirow{5}{*}{} & & \multicolumn{1}{c|}{ Unfiltered Water } & & \\
& & \multicolumn{1}{c|}{ Estimate } & Adjusted SE & Importance: \\
& (Intercept) & $1.23 \mathrm{E}-02$ & $1.14 \mathrm{E}-02$ & \\
Initial 12 & Conductivity & $-7.10 \mathrm{E}-06$ & $6.40 \mathrm{E}-06$ & 0.69 \\
Months & Temperature & $5.60 \mathrm{E}-05$ & $1.13 \mathrm{E}-04$ & 0.38 \\
& pH & $-2.20 \mathrm{E}-04$ & $1.30 \mathrm{E}-03$ & 0.29 \\
& Discharge & $-5.27 \mathrm{E}-08$ & $2.03 \mathrm{E}-07$ & 0.27 \\
\hline
\end{tabular}




\begin{tabular}{|c|c|c|c|c|}
\hline \multicolumn{5}{|c|}{ Unfiltered Water } \\
\hline \multirow{11}{*}{$\begin{array}{l}\text { Subsequent } \\
16 \text { Months }\end{array}$} & & Estimate & Adjusted SE & Importance: \\
\hline & (Intercept) & $1.94 \mathrm{E}-03$ & $2.44 \mathrm{E}-02$ & \\
\hline & Conductivity & $-1.03 \mathrm{E}-05$ & $1.13 \mathrm{E}-05$ & 0.59 \\
\hline & Temperature & 5.42E-04 & $2.17 \mathrm{E}-04$ & 0.96 \\
\hline & $\mathrm{pH}$ & $9.15 \mathrm{E}-04$ & $2.95 \mathrm{E}-03$ & 0.29 \\
\hline & Discharge & $-2.51 \mathrm{E}-09$ & 4.23E-07 & 0.26 \\
\hline & & Estimate & Adjusted SE & Importance: \\
\hline & (Intercept) & $3.25 \mathrm{E}-03$ & 4.67E-03 & \\
\hline & Temperature & 7.79E-04 & $2.29 \mathrm{E}-04$ & 0.99 \\
\hline & $\begin{array}{l}\text { Water Column Total } \\
\mathrm{N}\end{array}$ & $-2.96 \mathrm{E}-03$ & 2.03E-03 & 0.57 \\
\hline & $\begin{array}{l}\text { Water Column Total } \\
\mathrm{P}\end{array}$ & $-8.66 \mathrm{E}-03$ & $7.42 \mathrm{E}-03$ & 0.34 \\
\hline
\end{tabular}

\begin{tabular}{|c|c|c|c|c|}
\hline \multicolumn{5}{|c|}{ Periphyton } \\
\hline \multirow{6}{*}{$\begin{array}{c}\text { Initial } 12 \\
\text { Months }\end{array}$} & & Estimate & Adjusted SE & Importance: \\
\hline & (Intercept) & $-8.30 \mathrm{E}+00$ & $3.91 \mathrm{E}+01$ & \\
\hline & $\mathrm{pH}$ & $1.86 \mathrm{E}+00$ & $4.78 \mathrm{E}+00$ & 0.34 \\
\hline & Temperature & $-9.58 \mathrm{E}-05$ & $5.15 \mathrm{E}-04$ & 0.25 \\
\hline & Conductivity & $-1.81 \mathrm{E}-03$ & $8.24 \mathrm{E}-03$ & 0.26 \\
\hline & Discharge & $-2.83 \mathrm{E}-02$ & $1.36 \mathrm{E}-01$ & 0.27 \\
\hline \multirow{10}{*}{$\begin{array}{l}\text { Subsequent } \\
16 \text { Months }\end{array}$} & & Estimate & Adjusted SE & Importance: \\
\hline & (Intercept) & $-6.05 E+00$ & $2.79 \mathrm{E}+01$ & \\
\hline & $\mathrm{pH}$ & $2.05 \mathrm{E}-01$ & 2.31E-01 & 0.30 \\
\hline & Temperature & $1.04 \mathrm{E}+00$ & $3.42 \mathrm{E}+00$ & 0.57 \\
\hline & Conductivity & $-1.92 \mathrm{E}-04$ & $6.40 \mathrm{E}-04$ & 0.25 \\
\hline & Discharge & $-5.77 \mathrm{E}-04$ & $4.16 \mathrm{E}-03$ & 0.30 \\
\hline & & Estimate & Adjusted SE & Importance: \\
\hline & (Intercept) & $5.18 \mathrm{E}+00$ & $3.34 \mathrm{E}+00$ & \\
\hline & Sediment Total N & $-1.53 \mathrm{E}-03$ & $1.23 \mathrm{E}-02$ & 0.25 \\
\hline & Sediment Total P & $1.26 \mathrm{E}-04$ & $2.16 \mathrm{E}-03$ & 0.26 \\
\hline
\end{tabular}


Table 8. A summary of average morphometric and liver total MC/NOD data for smallmouth bass

(a) and golden redhorse sucker (b). Sample size is presented as $n$. K represents the modified

Fulton's condition factor. HSI represents hepatosomatic index. *Significance values for total

MCs were determined among sampling dates within a sampling location. Sites in which no

seasonal comparison can be made is presented as “_“. HSI was not calculated for golden redhorse

sucker.

\begin{tabular}{|c|c|c|c|c|c|c|c|c|c|c|c|}
\hline \multicolumn{12}{|c|}{ aSmallmouth Bass } \\
\hline Site Name & $\begin{array}{c}\text { Sample } \\
\text { Date }\end{array}$ & $n$ & $\begin{array}{c}\text { Length } \\
(\mathrm{mm})\end{array}$ & $\begin{array}{c}\text { Weight } \\
\text { (g) }\end{array}$ & Age & $\begin{array}{c}\text { Total } \\
\text { MC/NOD } \\
\text { (ng/g) } \\
\end{array}$ & $\begin{array}{c}\text { MC/NOD } \\
\text { Sig* }\end{array}$ & $\mathbf{K}$ & $\begin{array}{l}\text { K } \\
\text { Sig }\end{array}$ & HSI & $\begin{array}{c}\text { HSI } \\
\text { Sig }\end{array}$ \\
\hline $\begin{array}{c}\text { Monocacy } \\
\text { River near } \\
\text { Mouth near } \\
\text { Frederick, } \\
\text { MD } \\
\end{array}$ & $\begin{array}{l}\text { 8-Apr- } \\
2013\end{array}$ & 18 & 363.33 & 686.44 & 5.06 & 1.50 & - & 1.32 & $\mathrm{e}$ & 2.57 & $\mathrm{a}$ \\
\hline $\begin{array}{l}\text { Mainstem of } \\
\text { the North } \\
\text { Branch at } \\
\text { Cumberland, } \\
\text { MD }\end{array}$ & $\begin{array}{l}\text { 8-Apr- } \\
2013\end{array}$ & 18 & 341.00 & 538.89 & 6.11 & 0.92 & - & 1.28 & ace & 2.22 & $\mathrm{ad}$ \\
\hline \multirow{2}{*}{$\begin{array}{c}\text { Mainstem of } \\
\text { the Potomac } \\
\text { River near } \\
\text { Sharpsburg, } \\
\text { MD }\end{array}$} & $\begin{array}{c}\text { 29-Mar- } \\
2013 \\
\end{array}$ & 17 & 354.41 & 629.71 & 6.41 & 1.60 & - & 1.36 & ae & 2.61 & $\mathrm{a}$ \\
\hline & $\begin{array}{l}\text { 5-May- } \\
2015\end{array}$ & 19 & 317.32 & 429.63 & 5.11 & 4.02 & - & 1.28 & ace & 1.01 & $\mathrm{bc}$ \\
\hline \multirow{2}{*}{$\begin{array}{l}\text { Mainstem of } \\
\text { the South } \\
\text { Branch at } \\
\text { Petersburg, } \\
\text { WV }\end{array}$} & $\begin{array}{c}\text { 4-Apr- } \\
2013 \\
\end{array}$ & 18 & 333.83 & 520.67 & 5.67 & 1.07 & $\mathrm{a}$ & 1.22 & bce & 1.78 & ac \\
\hline & $\begin{array}{l}\text { 7-Aug- } \\
2013\end{array}$ & 17 & 301.59 & 358.65 & 4.06 & 4.86 & $\mathrm{~b}$ & 1.20 & bce & 0.81 & $\mathrm{~b}$ \\
\hline \multirow{3}{*}{$\begin{array}{l}\text { Mainstem of } \\
\text { the South } \\
\text { Branch near } \\
\text { Moorefield, } \\
\text { WV }\end{array}$} & $\begin{array}{c}\text { 5-Apr- } \\
2013 \\
\end{array}$ & 19 & 362.05 & 683.00 & 6.00 & 0.78 & $\mathrm{a}$ & 1.29 & ace & 2.34 & $\mathrm{a}$ \\
\hline & $\begin{array}{l}\text { 8-Aug- } \\
2013 \\
\end{array}$ & 20 & 313.10 & 393.30 & 4.37 & 7.05 & $\mathrm{~b}$ & NA & NA & NA & NA \\
\hline & $\begin{array}{l}\text { 7-May- } \\
2014\end{array}$ & 20 & 312.05 & 445.10 & 5.25 & 1.90 & $\mathrm{a}$ & 1.19 & $\mathrm{bc}$ & 1.09 & $\mathrm{bc}$ \\
\hline
\end{tabular}




\begin{tabular}{|c|c|c|c|c|c|c|c|c|c|c|c|}
\hline Site Name & $\begin{array}{c}\text { Sample } \\
\text { Date }\end{array}$ & $n$ & $\begin{array}{c}\text { Length } \\
\text { (mm) }\end{array}$ & $\begin{array}{c}\text { Weight } \\
\text { (g) }\end{array}$ & Age & $\begin{array}{c}\text { Total } \\
\text { MC/NOD } \\
(\text { ng/g) }\end{array}$ & $\begin{array}{c}\text { MC/NOD } \\
\text { Sig* }\end{array}$ & $\mathbf{K}$ & $\begin{array}{c}\text { K } \\
\text { Sig }\end{array}$ & HSI & $\begin{array}{l}\text { HSI } \\
\text { Sig }\end{array}$ \\
\hline \multirow{4}{*}{$\begin{array}{l}\text { Mainstem of } \\
\text { the South } \\
\text { Branch near } \\
\text { Moorefield, } \\
\text { WV }\end{array}$} & $\begin{array}{c}\text { 27-Aug- } \\
2014 \\
\end{array}$ & 20 & 258.60 & 251.45 & 4.00 & 13.43 & $\mathrm{~b}$ & 1.22 & bce & 0.72 & $\mathrm{~b}$ \\
\hline & $\begin{array}{c}\text { 7-Apr- } \\
2015 \\
\end{array}$ & 19 & 361.42 & 675.53 & 6.53 & 0.74 & $\mathrm{a}$ & 1.26 & ace & 2.19 & ae \\
\hline & $\begin{array}{c}\text { 4-May- } \\
2015 \\
\end{array}$ & 19 & 309.05 & 431.32 & 4.89 & 1.85 & $\mathrm{a}$ & 1.29 & ace & 1.39 & bcde \\
\hline & $\begin{array}{c}\text { 11-Aug- } \\
2015\end{array}$ & 18 & 292.28 & 343.11 & 3.72 & 7.74 & $\mathrm{~b}$ & 1.26 & ace & 0.65 & $\mathrm{~b}$ \\
\hline \multicolumn{10}{|c|}{ bolden Redhorse Sucker } & & \\
\hline Site Name & $\begin{array}{c}\text { Sample } \\
\text { Date }\end{array}$ & $n$ & $\begin{array}{c}\text { Length } \\
\text { (mm) }\end{array}$ & $\begin{array}{c}\text { Weight } \\
\text { (g) }\end{array}$ & Age & $\begin{array}{c}\text { Total } \\
\text { MC/NOD } \\
(\mathbf{n g} / \mathrm{g})\end{array}$ & $\begin{array}{c}\text { MC/NOD } \\
\text { Sig* }\end{array}$ & $\mathbf{K}$ & $\begin{array}{c}\text { K } \\
\text { Sig }\end{array}$ & & \\
\hline \multirow{6}{*}{$\begin{array}{l}\text { Mainstem of } \\
\text { the North } \\
\text { Branch at } \\
\text { Cumberland, } \\
\text { MD }\end{array}$} & 8-Apr-2013 & 20 & 442.35 & 1208.40 & 8.45 & 0.42 & $\mathrm{a}$ & 1.30 & $\mathrm{a}$ & & \\
\hline & $\begin{array}{c}\text { 22-Aug- } \\
2013 \\
\end{array}$ & 11 & 388.18 & 687.55 & 5.27 & 2.82 & $\mathrm{~b}$ & 1.09 & $a b$ & & \\
\hline & 3-Jun-2014 & 20 & 396.20 & 764.30 & 5.50 & 0.65 & $\mathrm{ac}$ & 1.19 & $a b$ & & \\
\hline & $\begin{array}{c}\text { 26-Aug- } \\
2014 \\
\end{array}$ & 19 & 430.16 & 903.26 & 6.37 & 3.52 & $\mathrm{bc}$ & 1.10 & $a b$ & & \\
\hline & 6-Apr-2015 & 20 & 431.45 & 920.30 & 7.05 & 1.45 & $\mathrm{bc}$ & 1.07 & $a b$ & & \\
\hline & $\begin{array}{c}\text { 12-Aug- } \\
2015\end{array}$ & 19 & 447.37 & 891.63 & 6.42 & 2.37 & $\mathrm{~b}$ & 1.02 & $\mathrm{~b}$ & & \\
\hline \multirow{2}{*}{$\begin{array}{l}\text { Mainstem of } \\
\text { the South } \\
\text { Branch at } \\
\text { Petersburg, } \\
\text { WV }\end{array}$} & 4-Apr-2013 & 18 & 477.61 & 1312.78 & 7.33 & 1.03 & $\mathrm{a}$ & 1.12 & $a b$ & & \\
\hline & $\begin{array}{c}\text { 7-Aug- } \\
2013\end{array}$ & 18 & 367.56 & 556.50 & 3.11 & 5.72 & $\mathrm{~b}$ & 1.10 & $a b$ & & \\
\hline \multirow{7}{*}{$\begin{array}{l}\text { Mainstem of } \\
\text { the South } \\
\text { Branch near } \\
\text { Moorefield, } \\
\text { WV }\end{array}$} & 5-Apr-2013 & 20 & 478.05 & 1374.75 & 8.45 & 0.13 & $\mathrm{a}$ & 1.17 & $a b$ & & \\
\hline & $\begin{array}{c}\text { 8-Aug- } \\
2013 \\
\end{array}$ & 20 & 439.10 & 964.47 & 4.65 & 6.27 & $\mathrm{~cd}$ & NA & NA & & \\
\hline & $\begin{array}{c}\text { 7-May- } \\
2014 \\
\end{array}$ & 20 & 426.50 & 988.75 & 4.95 & 1.13 & $\mathrm{~b}$ & 1.20 & $a b$ & & \\
\hline & 2-Jun-2014 & 20 & 435.95 & 1022.45 & 5.95 & 1.89 & $\mathrm{~cd}$ & 1.20 & $\mathrm{ab}$ & & \\
\hline & $\begin{array}{c}\text { 27-Aug- } \\
2014 \\
\end{array}$ & 20 & 434.05 & 996.75 & 4.30 & 6.14 & $\mathrm{~cd}$ & 1.17 & $a b$ & & \\
\hline & 7-Apr-2015 & 20 & 444.55 & 1029.00 & 5.05 & 2.12 & $\mathrm{bc}$ & 1.10 & $\mathrm{ab}$ & & \\
\hline & $\begin{array}{c}\text { 11-Aug- } \\
2015\end{array}$ & 19 & 454.58 & 1087.00 & 5.92 & 8.77 & $\mathrm{~d}$ & NA & NA & & \\
\hline
\end{tabular}




\title{
Chapter Three: Hepatocyte and Leukocyte Transcript Abundance Profiles of Smallmouth Bass (Micropterus dolomieu) Challenged with Microcystin-LR
}

\begin{abstract}
Cyanobacterial blooms are of increasing concern worldwide as both a nuisance and due to their production of toxins in select species. The cyanobacterial hepatotoxin microcystinLR (MCLR) has been shown to disrupt a variety of genes in the liver and anterior kidneys of fishes. These toxins have been shown to occur within the Potomac River watershed in which the smallmouth bass (SMB; Micropterus dolomieu) is a popular sport fish. The temporal transcriptional response of SMB hepatocytes to environmentally relevant concentrations of $\operatorname{MCLR}(0.05,0.5$, and $5.0 \mathrm{ng} / \mathrm{mL})$, as well as the effect of these concentrations of MCLR on peptidoglycan (PGN) stimulated SMB leukocytes was assessed. A reference leukocyte transcriptome was first developed using next-generation sequencing. Independent libraries of leukocyte and hepatic genes-of-interest were subsequently generated. Hepatic transcripts included those which are shown to be affected by MCLR, as well as those indicative of endocrine disruption. Leukocyte transcripts focused on the toll-like receptor 1/2 pathway (which is activated by PGN); as well as transcripts shown to be affected by MCLR. These were included in a customized CodeSet and analyzed using the NanoString ${ }^{\circledR}$ nCounter technologies. No significant differences among hepatocyte treatments or leukocyte treatments treated only with MCLR were reported. However differences in PGN-stimulated and PGN-MCLR coexposed leukocytes were observed when compared to unexposed. Although these data do not show statistically or biologically relevant transcriptional disruption by MCLR, it does show that MCLR acts concomitantly with peptidoglycan to up- or down-regulate select leukocyte transcripts.
\end{abstract}




\section{Introduction}

Chronic mortality of fish has been reported in a variety of species within the Chesapeake Bay drainage. Some of these events have been linked to specific pathogens such as Aphanomyces invadans which infects Atlantic menhaden Brevoortia tyrannus (Blazer et al. 2002) and Mycobacterium spp. which infect striped bass Morone saxatilis (Gauthier et al. 2008) and other species. There are however, reported fish kill events which have no clear correlation to any one specific pathogen or contaminant. Although a variety of pathogens were identified (such as trematodes, myxozoans, Aeromonas hydrophila, A. salmonicida, Flavobacterium columnare, and largemouth bass virus) in recent kills of smallmouth bass Micropterus dolomieu, no clear cause could be derived. This is likely due to a variety of contributing factors which lead to diminished overall fish health (Blazer et al. 2010).

Cyanobacteria are a large phylum which inhabits marine and freshwater systems. Cyanotoxins are a secondary metabolite of a subset of these cyanobacteria. Cyanotoxins are generally grouped by the target tissue. Hepatotoxins are a group which includes the 89 known variants of microcystin (MC), as well as nodularin. Much of the research specific to microcystins has focused on the variant -LR (MCLR). Microcystins act as a potent inhibitor of the serine/threonine-specific protein phosphatases 1 and 2A (Runnegar et al. 1995). The inhibition of these enzymes leads to the dysregulation of intracellular glycogen, as well as the collapse of sinusoidal capillaries (Dawson 1998; Dittmann and Wiegand 2006).

One cellular process to detoxify compounds is the generation of reactive oxygen species (ROS; Lushchak (2014)). Oxidative stress is the condition within cells when the production of ROS exceeds the cell's ability to neutralize their effects and may be induced by a variety of compounds (Lushchak 2016). The MCLR exposure has been shown to induce various enzymes 
associated with oxidative stress. Pflugmacher et al. (1998) identified increased activity of glutathione (GSH), as well as the catalyst enzyme glutathione-S-transferase (GST), which is believed to be the first step in the detoxification of MC. Bouaicha and Maatouk (2004) evaluated rat hepatocytes in vitro and observed an acute increase in GSH three hours post-exposure, as well as an increase in ROS 0-60 minutes post-exposure. Glutathione was not different than controls 24 or 48 hours post-exposure. Jayaraj et al. (2006) showed a decrease in the activity of glutathione peroxidase (GPX), superoxide dismutase (SOD), and catalase (CAT) 120 minutes post-exposure while only CAT was significantly decreased one, three, and seven days postexposure. They theorized this resulted from a depletion of intracellular stores of glutathione resulting from the effects of oxidative stress. This is supported by the increase in the genes that encode heat shock protein-70 (HSP70) and glutathione reductase (GSR) within the first two hours post-exposure, both of which protect against the effects of oxidative stress.

Microcystin-producing cyanobacteria have been shown to modulate the expression of a suite of genes in vivo. Rogers et al. (2011) report an up-regulation in the gene that encodes vitellogenin (vtg, vtgl, vtg2, and $v \operatorname{tg} 3$ ) in zebrafish (Danio rerio) when exposed to MCproducing cyanobacterial lysate. They also observed a significant down-regulation among genes associated with a variety of other pathways such as cell signaling and development. Marie et al. (2012) showed similar results using medaka (Oryzias lapites). Wei et al. (2008) identified genes associated with mitogen-activated protein kinases (MAPK) and immune pathways in zebrafish which were up-regulated when exposed to purified MCLR. Zhao et al. (2015) observed the upregulation in a suite of genes associated with the hypothalamic-pituitary-gonadal axis, ovarian maturation, and vitellogenin and exposure to MCLR $2 \mu \mathrm{g} / \mathrm{L}$ and $10 \mu \mathrm{g} / \mathrm{L}$. Interestingly, these associations were not consistently observed at $50 \mu \mathrm{g} / \mathrm{L}$ (likely due to cytotoxicity). 
Microcystins have been shown to up-regulate immune-relevant genes as well. Rymuszka and Adaszek (2012) quantified the pro-inflammatory cytokines interleukin-1 $\beta$ (IL1B) and tumor necrosis factor- $\alpha$ (TNF- $\alpha)$, as well as the anti-inflammatory interleukin-10 (IL-10) and transforming growth factor- $\beta$ (TGFB) in common carp Cyprinus carpio leukocytes isolated both from blood and anterior kidney. The authors observed an up-regulation at the low MCLR dose $(0.01 \mu \mathrm{g} / \mathrm{mL})$. Conversely, they reported a down-regulation at the high MCLR dose $(0.1 \mu \mathrm{g} / \mathrm{mL})$. Their results began to shed light on the observed immunomodulation as previously mentioned. They document an upregulation of certain pro-inflammatory cytokines at low doses of MC and a nominal upregulation of anti-inflammatory cytokines at these concentrations. However, at higher concentrations the anti-inflammatory transcripts are significantly higher and may be overwhelming the pro-inflammatory cytokines. It should be noted that their treatment concentrations were 10x and 100x higher than the WHO guideline of $1.0 \mu \mathrm{g} / \mathrm{L}$ for the MC variant -LR in drinking water (WHO 1998).

Chen et al. (2017) quantified a variety of endpoints of oxidative stress (the enzymes superoxide dismutase, catalase, and glutathione peroxidase), as well as pro-inflammatory cytokines in common carp following intraperitoneal injection of $150 \mu \mathrm{g} / \mathrm{kg}$ MCLR. The specific transcriptional endpoints were the pro-inflammatory IL1B, TNF- $\alpha$, interferon type I, as well as the chaperonins heat shock protein 70 and 90 . They observed an upregulation in all of the oxidative stress endpoints 12 hours post-injection. Most of these enzymes returned to prechallenge levels after 96 hours. Similarly, both chaperonins were upregulated 12 hours postinjection following MCLR exposure but returned to baseline levels after 96 hours. All three proinflammatory cytokines were upregulated at all time periods ( $12-96$ hours post injection). 
Overall, the response of oxidative stress and chaperonin endpoints suggest detoxification and clearing of the toxin.

The first objective of this chapter is to quantify select transcript abundance of smallmouth bass (SMB) hepatocytes to in vitro exposure of three concentrations of purified MCLR. The second objective was to investigate the effects of MC toxin on the transcriptional response of leukocytes to a bacterial antigen.

\section{Methods}

\subsection{Hepatocyte assay}

Yearling smallmouth bass were acclimated at the U.S. Geological Survey in Leetown, WV. Eight bass ( 6 males and 2 females) were randomly selected and euthanized using a lethal dose of tricaine methanesulfonate (MS-222) in each of two independent trials. Hepatocytes were isolated using methods modified from Mommsen et al. (1994). Briefly, fish were bled via a puncture of the caudal vein to minimize the contamination of tissue by erythrocytes. Following exsanguination, the liver was aseptically removed and separated from the gall bladder. Livers were transported in Leibovitz's L-15 growth medium containing 5\% (v/v) of charcoal/dextran stripped fetal bovine serum (FBS), supplemented with 100 units $\backslash \mathrm{ml}$ penicillin, $100 \mu \mathrm{g} \backslash \mathrm{ml}$ streptomycin, and $292 \mu \mathrm{g} \backslash \mathrm{ml}$ L-glutamine (L-15 5\% PSG; Sigma-Aldrich, St. Louis, MO) on wet ice. Tissues were punctured and perfused using a $3 \mathrm{~mL}$ syringe with a $253 / 8$-gauge needle containing 5mL Dulbecco's Phosphate-Buffered Saline (DPBS; Sigma-Aldrich, St. Louis, MO), $5 \mathrm{mM}$ (Ethylenedinitrilo)tetraacetic acid calcium disodium salt (EDTA; Sigma-Aldrich, St. Louis, MO) and $10 \mathrm{KU}$ of sodium heparin (Sigma-Aldrich, St. Louis, MO) per mL. All media was removed and repeated with a $5 \mathrm{~mL}$ second rinse of the DPBS-EDTA-heparin solution. Once 
all erythrocytes were flushed (identified by a color change in tissue), the tissue was perfused with $10 \mathrm{~mL}$ of DPBS with type-2 collagenase $(1.0 \mathrm{mg} / \mathrm{mL}$; Sigma-Aldrich, St. Louis, MO) and massaged for 10 minutes. The media was removed and $10 \mathrm{~mL}$ of DPBS-EDTA-heparin was added. The liver was then cut into small pieces using a sterile surgical scalpel and disassociated for 20 minutes by gently expressing them with a $3 \mathrm{~mL}$ syringe. The resulting suspension was pipetted through a cell strainer $(213 \mu \mathrm{m}$ sterile steel mesh pre-filter in series with a $70 \mu \mathrm{m}$ cell strainer). The resulting substrate was strained into a $50 \mathrm{~mL}$ polypropylene conical tube. Following 10 minutes of centrifugation at $70 \mathrm{x} g$ average at $4^{\circ} \mathrm{C}$, the solution was resuspended in $10 \mathrm{~mL}$ DPBS-EDTA-heparin and centrifuged again for 10 minutes at $70 \mathrm{xg}$ average at $4{ }^{\circ} \mathrm{C}$. Cells were resuspended in $10 \mathrm{~mL} \mathrm{L-15} \mathrm{5 \%} \mathrm{PSG} \mathrm{and} 10 \mu \mathrm{L}$ of this suspension was added to 10 $\mu \mathrm{L}$ of $4 \%$ trypan blue and the total number of cells and viability was determined using the Countess ${ }^{\circledR}$ II automated cell counter (Life Technologies, Carlsbad, CA). Hepatocytes were adjusted to a concentration of $4 \times 10^{5}$ cells $/ 100 \mu \mathrm{L}$ in L-15 5\% PSG. A total of $105 \mu \mathrm{L}$ of the cell suspension was transferred to each cell of a 96-well plate (Costar 3396, Corning, NY).

The concentrations of MCLR used are based on those presented for cultured cells (X. Li et al. 2003; Takumi et al. 2010) and preliminary data for concentrations present in the environment. The concentrations are $0.05,0.5$, and $5.0 \mathrm{ng} / \mathrm{mL}$. Additionally, the concentration of $50.0 \mathrm{ng} / \mathrm{mL}$ was included in the second challenge. Stock concentrations of MCLR were solubilized in dimethyl sulfoxide (DMSO; Sigma-Aldrich, St. Louis, MO). Microcystin-LR was diluted to the desired working concentrations of $0.1 \%$ DMSO in L-15 5\% PSG and $105 \mu \mathrm{L}$ of MCLR at the desired concentration to each well. The final hepatocyte concentration was $2 \times 10^{5} /$ $100 \mu \mathrm{L}$ in $\mathrm{L}-155 \% \mathrm{PSG}+0.05 \%$ DMSO. Plates were placed within a humidified chamber in a $20{ }^{\circ} \mathrm{C}$ incubator. Hepatocytes were challenged for 6, 12, and 24 hours. Following each 
incubation, $10 \mu \mathrm{L}$ of the cell suspension was reserved for viability determined using the Countess ${ }^{\circledR}$ II automated cell counter as described above. The remaining $200 \mu \mathrm{L}$ suspension was centrifuged for 10 minutes at $70 \mathrm{x} g$ average (noting that $200 \mu \mathrm{L}$ yielded the optimized cellular concentration for downstream transcript abundance analysis). Supernatant was removed and 100 $\mu \mathrm{L}$ of TRK lysis buffer (Omega Biotek, Norcross, GA) containing 0.02\% 2-Mercaptoethanol (Sigma-Aldrich, St. Louis, MO) was then added to each sample well. The resulting lysate was transferred to a $0.2 \mathrm{~mL} 8$-strip PCR tube with cap (USA Scientific, Ocala, FL) and stored at $80^{\circ} \mathrm{C}$ until analysis.

\subsection{Anterior kidney stimulation}

The first step was to map the anterior kidney tissue transcriptome for SMB. This was performed using tissue from adult SMB collected in 2015 from the Susquehanna River basin. Anterior kidney cells were isolated and stimulated using methods described by Sharp et al. (1991). Briefly, whole anterior kidney was aseptically removed and placed into a Falcon ${ }^{\circledR} 15 \mathrm{~mL}$ conical tube (Corning Inc., Corning, NY) containing sterile Leibovitz's L-15 media (SigmaAldrich, St. Louis, MO) supplemented with $10 \mathrm{KU} \backslash \mathrm{ml}$ sodium heparin, 100 units $\backslash \mathrm{ml}$ penicillin, $100 \mu \mathrm{g} \backslash \mathrm{ml}$ streptomycin, and 2\% (v/v) fetal bovine serum (L-15 2\%) and stored on wet ice.

A single-cell suspension was then created by pouring the contents of the conical tube into a sterile $100 \mathrm{~mm}$ x $15 \mathrm{~mm}$ petri dish and expressed with a sterile three $\mathrm{mL}$ BD Luer-Lok ${ }^{\mathrm{TM}}$ syringe (Becton Dickinson, Franklin Lakes, NJ). The suspension was filtered using a 70 $\mu \mathrm{m}$ Falcon $^{\mathrm{TM}}$ cell strainer (Becton Dickinson, Franklin Lakes, NJ) into a $50 \mathrm{~mL}$ conical tube (Corning Inc., Corning, NY) and then transferred back into the original $15 \mathrm{~mL}$ conical tube. The suspension was centrifuged for 10 minutes at $4^{\circ} \mathrm{C}$ at $500 \mathrm{~g}$. The supernatant was removed, and the resulting pellet was suspended in $10 \mathrm{~mL}$ of fresh L-15 2\%. The cells were centrifuged for 10 
minutes at $4^{\circ} \mathrm{C}$ at $500 \mathrm{~g}$ and the cells washed two more times with L-15 2\%. We then combined $10 \mu \mathrm{L}$ of the resulting suspension with $90 \mu \mathrm{L}$ of Trypan blue (Sigma Aldrich, St. Louis, MO) and counted using one square in a hemocytometer. The calculation is as follows: Total cells per $\mathrm{mL}=$ total calls counted $* 100000$. Cells were diluted to a final concentration of $5 \times 10^{5}$ cells per mL in Leibovitz's L-15 media supplemented with 100 units/ml penicillin, $100 \mu \mathrm{g} / \mathrm{ml}$ streptomycin, and $5 \%(\mathrm{v} / \mathrm{v})$ fetal bovine serum (L-15 5\%) and $1 \mathrm{~mL}$ was transferred to a 24-well Costar® 3527 TCTreated multiple well plate (Corning Inc., Corning, NY). Cells were challenged for 18 hours at $15^{\circ} \mathrm{C}$ with $0.05 \mathrm{ng} / \mathrm{mL}$ MCLR, $20 \mu \mathrm{g} / \mathrm{mL}$ peptidoglycan (PGN; Sigma Aldrich, St. Louis, MO), $10 \mu \mathrm{g} / \mathrm{mL}$ polyinosinic-polycytidylic acid sodium salt (Poly I:C; Sigma Aldrich, St. Louis, MO), 5 mg/mL zymosan A from Saccharomyces cerevisiae (Sigma Aldrich, St. Louis, MO), or lectin from Phaseolus vulgaris (PHA-P; Sigma Aldrich, St. Louis, MO).

\subsection{RNA isolation and sequencing}

Each sample was lysed, and total RNA extracted (including DNAse) using protocols specific to Omega Bio-tek (Norcross, GA). Total RNA was quantified among individual samples using the Quant-iT ${ }^{\mathrm{TM}}$ RNA assay kit (Invitrogen Corporation, Carlsbad, CA) and normalized accordingly. Sample aliquots were then pooled among immune-stimulant treatment group. The RNA integrity number (RIN) for each pooled treatment group was quantified using an Agilent RNA 6000 Nano Chip (Agilent Technologies, Santa Clara, CA) on the Agilent 2100 bioanalyzer (Agilent Technologies, Santa Clara, CA) and verified to be $\geq 8$. Samples were shipped to the University of Maryland School of Medicine Institute for Genome Sciences (Baltimore, MD) for sequencing on the Illumina HiSeq 4000 (Illumina, San Diego, CA). Barcoded strand specific RNA-seq was performed. 


\subsection{Bioinformatics}

Paired-end (PE) sequencing reads were imported into CLC Genomics Workbench v9.3 (Quiagen, Hilden, Germany) for quality trimming and de novo assembly. These PE reads were imported from control, Poly I:C, PHA-P and zymosan A stimulated cells to establish a de novo reference transcriptome (the PGN treatment was omitted as the other immunostimulants provided a more comprehensive contig list). Assembly utilized the default parameters and contigs less than 200 base pairs (bp) were culled from the reference. A reference transcriptome was assembled and annotated by pooling all four select treatment groups. This set of reference sequences was annotated using Blast2Go. An RNAseq analysis was conducted in CLC

Genomics Workbench v9.3 (Qiagen, Hilden, Germany) to coarsely identify genes differentially regulated by immune stimulation.

\subsection{Leukocyte isolation and PGN/MCLR challenge}

Nine SMB (5 females and 4 males) were collected from ponds located at the United States Geological Survey Leetown Science Center (Kearneysville, WV). Fish were acclimated indoors for three weeks at $13.7^{\circ} \mathrm{C}$ prior to exposure and fed twice weekly to satiation with live fathead minnows Pimephales promelas and bluegill Lepomis macrochirus. Fish were euthanized using a lethal dose of MS-222. Leukocytes were isolated as described above with the following addendum. Prior to counting cells, cells were suspended in $6 \mathrm{~mL} \mathrm{L-152 \%}$ and carefully layered on top of a $32 \%$ Percoll in Hanks Balanced Salt Solution (HBSS; Sigma Aldrich, St. Louis, MO) in a $15 \mathrm{~mL}$ conical tube. This was centrifuged at $500 \mathrm{~g}$ for 45 minutes at $4^{\circ} \mathrm{C}$. Leukocytes were removed and washed three times in L-15 2\%. Following the final wash, cells were suspended in $10 \mathrm{~mL}$ L-15 2\% and combined 1:1 by volume with Trypan blue. Cells were counted, and viability was determined using the Countess ${ }^{\circledR}$ II automated cell counter (Life Technologies, 
Carlsbad, CA). Cells were diluted to a final concentration of $1 \times 10^{7}$ cells $/ \mathrm{mL}$ in L-15 5\%. Duplicate 96-well Costar® 3598 Polystyrene TC-Treated Microplates (Corning Inc., Corning, NY) were used containing $5 \times 10^{5}$ cells per each treatment well. Treatment groups were: carrier control (methanol), $20 \mu \mathrm{g} / \mathrm{mL}$ PGN, $0.05 \mathrm{ng} / \mathrm{mL}$ MCLR, $0.50 \mathrm{ng} / \mathrm{mL}$ MCLR, $5.00 \mathrm{ng} / \mathrm{mL}$ MCLR, $0.05 \mathrm{ng} / \mathrm{mL}$ MCLR + $20 \mu \mathrm{g} / \mathrm{mL}$ PGN, $0.50 \mathrm{ng} / \mathrm{mL}+20 \mu \mathrm{g} / \mathrm{mL}$ PGN MCLR, or 5.00 $\mathrm{ng} / \mathrm{mL}$ MCLR $+20 \mu \mathrm{g} / \mathrm{mL}$ PGN. Cells were challenged at $17.5^{\circ} \mathrm{C}$ for 18 hours. Following the challenge, cells from one plate were lysed using TRK lysis buffer (Omega Bio-tek, Norcross, GA) supplemented with 2-mercaptoethanol (Sigma Aldrich, St. Louis, MO) and stored at $-80^{\circ} \mathrm{C}$ prior to analysis using the NanoString nCounter SPRINT ${ }^{\mathrm{TM}}$ (NanoString Technologies, Seattle, WA). Viability was quantified using the second plate using the automated cell counter method described above.

\subsection{Transcript list development}

Genes were selected for the hepatocyte assay primarily based on the known oxidative stress and endocrine disrupting effects of MC on fishes in the literature (Table 1). In addition to these, a suite of genes associated with endocrine disruption, stress, and contaminants were also included; as well as the six housekeeper genes: 40S ribosomal protein S12 (RPS12), elongation factor $1 \alpha(E F 1 \alpha)$, eukaryotic translation initiation factor 3D (ETIF3D), hypoxanthine phosphoribosyltransferase 1 (HPRT1), ribosomal protein L8 (RPL8), and tata box binding protein (TBP). Specific sequences adapted to SMB were based on Hahn et al. (2016). A full summary of the genes selected are included in Table 2 .

A SMB leukocyte custom CodeSet was developed using target and housekeeper genes identified both in the literature and from our HiSeq 4000 runs for MC and PGN (Table 3). Specifically, TNF- $\alpha$, TGFB, IL1B, and suppressor of cytokine signaling 3 (SOCS3) have been 
shown to be differentially expressed by exposure to microcystins (Rymuszka and Adaszek 2012, 2013; LiLi Wei et al. 2018). Additionally, genes were included from the TLR-1/2 pathway (Figure 1) which responds to a PGN stimulus (Rebl et al. 2010). Additional genes were included which are associated with general immune function.

\subsection{Transcript abundance normalization and quantification}

Transcriptome databases for SMB were utilized in the creation of each custom CodeSet designed by NanoString Technologies (Seattle, WA). Transcript abundance was analyzed at the United States Geological Survey, Leetown Science Center (Kearneysville, WV) using the NanoString nCounter SPRINT ${ }^{\text {TM }}$ (NanoString Technologies, Seattle, WA). Abundance counts were normalized using nSolver Analysis Software (v3.0). Each study was analyzed independently.

\subsection{Quantitative analysis}

All statistical analysis was performed within the R statistical package (R Core Development Team, 2017). Statistical significance was determined at $\alpha=0.05$. Housekeeping genes were assessed using the Normfinder algorithm as presented in Andersen et al. (2004). Transcript abundance was normalized using the SSolver $^{\mathrm{TM}}$ analysis software v3.0 (NanoString

Technologies, Seattle, WA). Quality control was performed as defined by Hahn et al. (2016). Transcript abundance was initially quantified using parametric methods which incorporate Bayesian methodologies to reduce the likelihood of false discovery. We examined both the Bioconductor edgeR package defined by Robinson et al. (2010) and the NanoStringDiff package as defined by Wang et al. (2016). These analyses were rejected based on inconsistent differences observed between these analyses techniques among treatment groups. These inconsistencies 
likely result from the low sample size within each treatment group. Therefore, the KruskalWallis test was used with the Multiple Experiment Viewer software defined in Howe et al. (2011). The Wilcoxon rank-sum test was incorporated if significant differences were identified.

\section{Results}

\subsection{Transcript abundance using hepatocyte assay}

A low decrease in viability was observed in each of the hepatocyte challenges $(\leq 1.27 \%$ and $\leq 1.94 \%$ for the challenges on January 16, 2018 and February 26, 2018, respectively). These were not associated with any specific treatment, individual, or time point. Both challenges were normalized together as one large experiment. Based on the stability analysis, only the housekeeping genes 40S12, EF1a and RPL8 were used.

A summary of the hepatocyte transcript abundance results is provided in Tables 4 and 5 . The controls for each time period were significantly different between the two challenges; therefore, each challenge was analyzed independently. Vitellogenin counts were only observed in two individuals (one female in each challenge) and thus were removed from further analysis. No transcripts were significantly different either among treatment or among exposure time during either challenge.

\subsection{Leukocyte Sequencing and RNAseq}

Metrics of treatment library specific sequencing are listed in Table 6. A total of 189,359 contigs were identified greater than 200bp. Sequences mapped to 33,950 annotated contigs representing complete or partial gene sequences during RNAseq analysis. A total of 2431, 1667, or 1366 genes were upregulated greater than 2.5 -fold relative to controls following zymosan A, Poly I:C or PHA-P stimulation, respectively. 


\subsection{MCLR-PGN leukocyte challenge}

A minimal decrease in cell viability was observed $(\leq 0.7 \%)$ which was not associated with any treatment group or individual. The housekeeping genes ETIF3D, RPL8, and 40S S12 were rejected due to poor stability among sex and among treatment. Only EF1a was retained as a housekeeping gene based on high stability among sex and among treatment group. A total of 12 genes were removed from analysis due to minimal expression among treatment groups.

Table 7 provides a summary of all statistically significant differentially expressed transcript abundance results. An additional 33 transcripts were removed as there were no significant differences among treatment groups. There were also no significant differences among sex. A significant upregulation of the pro-inflammatory cytokine IL1B, cyclooxygenase-2 (PTGS2); the cytokine CCL-CUa; the two chemokines interleukin 8 (CXCL8) and RANTES (CCL5); and suppressor of cytokine signaling-3 (SOCS3) were reported in the PGN and PGN co-exposure treatments as compared to the $\mathrm{MeOH}$ control. The only transcripts that were significantly different among MCLR treatments were MAP3K8 (high-dose only) and NCF1 (medium and high dose). All other differences were only reported in PGN-associated treatments.

$\log _{2}$ fold changes relative to the $\mathrm{MeOH}$ control are presented in Figure 2. All treatments except for B-cell receptor CD22 resulted in a relative upregulation. Appreciable fold changes (>2.0) were observed in all of our significantly differentially expressed genes except for NCF1. Generally, these differences were only the PGN and PGN co-stimulated treatment groups.

\section{Discussion}

No significant transcriptional activation or suppression was observed in hepatocytes in any of the treatment groups. Only weak temporal and/or dose trends were observed. The minimal 
effects of CYP1A are consistent with Wang et al. (2006) which suggest that CYPs do not play a pivotal role in the metabolism of MCLR. We did not find significant dysregulation of GST $\theta$ or GST $\rho$. As discussed earlier, GSH (catalyzed by GST) has been shown to be the first step in the detoxification of MCLR (Pflugmacher et al. 1998). However, an upward trend in rho-class transcripts is noted as compared to theta-class GST. It is unclear whether the minimal effect of theta-class represents a downregulation as compared to rho-class or is rho-class play a greater role in detoxification in SMB. This may result from a temporal and dose-response in response to ROS as indicated by GPX transcripts. Glutathione peroxidase, SOD, and CAT would all be expected to be involved in protecting cells from the effects from ROS as discussed in Li et al. (2003). Moderate changes in GPX were observed at the 12- and 24-hour time points in the second and first challenge, respectively. This may suggest variable response time and intensity to intracellular hydrogen peroxide as noted by the increased abundance in GSR in the $50 \mathrm{ng} / \mathrm{mL}$ dose. However, the lack of significant results cannot be discounted meaning these concentrations of MCLR simply may not result in a hepatic transcriptional response under these conditions.

Activation of genes associated with most components of the TLR pathway by PGN was observed (Figure 1). Most of the statistically significant activation was observed at (but not restricted to) end nodes (cytokines and chemokines). There is also observed evidence of both NF- $\kappa$ B and MAPK pathway activation. One omission was TLR2. This may have resulted from an inadequate probe or the experiment's kinetics. Leukocytes were challenged for 18 hours and the possibility that many of the transcripts had already been "turned off" when cells were sampled cannot be ruled out. We observed an activation of SOCS3. This may be compensatory as SOCS3 is activated by cytokines and acts to inhibit their effects (Wang et al. 2011). Reduced 
activation of CD22 was also observed. As CD22 acts to inhibit B-cell signaling (Li et al. 2017), a reduction of transcripts may suggest an increase in B-cell signaling.

Several dose-dependent trends are noted in the leukocyte challenge although there were no statistically significant differences among MCLR treatments. For example, an increased abundance of IL1B was observed similar to Rymuszka and Adaszek (2012). However, unlike their results, a reduction of IL1B at higher concentrations was not observed. Similar nonsignificant dose-response in the chemokines CCL5 and CXCL8, and the RELA subunit of the transcription factor NF- $\mathrm{kB}$ were reported. Overall, this may suggest that increased concentration of MCLR may be driving increased transcription of pro-inflammatory cytokines and chemokines. However, given the minimal $\log _{2}$ fold changes and statistical insignificance in most transcripts, it is more likely that MCLR at these concentrations does not influence these transcripts at a biologically meaningful level.

Differential transcript abundance was reported in 14 genes. In all of these except for NCF1, the coexposure with PGN yielded greater up- or downregulation as compared to MCLR alone (noting no significant differences in most MCLR treatment as compared to controls). A slight concomitant effect was observed among PGN and MCLR in ten transcripts (CCL5, CD22, CXCL8, IL1B, JUN, PTGS2, SOCS3, CHUK, NFKB2, and PIK3R5). While the possible additive effect is noteworthy, perhaps of more importance is coexposure with PGN elevated (or lowered) these transcript counts to a statistically significant level as compared to the control. As shown in Chapter Two, the concentrations of microcystin/nodularins in the environment are $\leq$ $0.05 \mathrm{ng} / \mathrm{mL}$ and persisted throughout much of the calendar year. This study has shown that acute exposure to MCLR does not negate the effects of PGN and may additively influence the expression of cytokines and chemokines transcript abundance. It is unclear whether such chronic 
exposure to MCLR causes associated stress on the immune system. A further investigation would be needed to test this hypothesis both in vitro and in the environment.

To our knowledge, this is the first MCLR challenge using SMB hepatocytes, as well as the first PRN-MCLR coexposure challenge using SMB leukocytes. This exposure taken with the literature would suggest that these concentrations of MCLR alone are unlikely to elicit a strong immune response. However, given the known occurrence of microcystins and bacteria in the environment, the biological significance of these results in the context of concomitant exposure cannot be ruled out. Hepatocytes were not coexposed to MCLR and an additional compound. However given the leukocyte results, we also cannot rule out the possibility of an effect (synergistic, antagonistic, or concomitant) given the suite of other endocrine disrupting compounds, bacteria, viruses, and parasites which have been previously shown to be present within the Potomac River watershed (Alvarez et al. 2009; Blazer et al. 2010; Kolpin et al. 2013). Experiments addressing these mixture effects should also incorporate temporal effects. In leukocytes for example, Kono et al. (2004) noted maximum expression of bactericidal permeability-increasing protein/LPS binding protein after four hours while granulocyte colony stimulating factor receptor activity peaked after 12 hours. Challenging SMB leukocytes at various temporal points may yield further insights into not only the response to PGN stimulation, but also the temporal response to MCLR. Further research would be required to determine the hepatic transcriptional response of hepatocytes to this mixture. 


\section{Literature Cited}

Alvarez-Pellitero, P. (2008). Fish immunity and parasite infections: from innate immunity to immunoprophylactic prospects. Veterinary Immunology and Immunopathology, 126(3-4).

Alvarez, D. A., Cranor, W. L., Perkins, S. D., Schroeder, V. L., Iwanowicz, L. R., Clark, R. C., et al. (2009). Reproductive health of bass in the Potomac, USA, drainage: Part 2. Seasonal occurrence of persistent and emerging organic contaminants. Environmental Toxicology and Chemistry, 28(5), 1084-1095.

Andersen, C. L., Jensen, J. L., \& Ørntoft, T. F. (2004). Normalization of Real-Time Quantitative Reverse Transcription-PCR Data: A Model-Based Variance Estimation Approach to Identify Genes Suited for Normalization, Applied to Bladder and Colon Cancer Data Sets. Cancer Research, 64, 5245-5250.

Blazer, V. S., Iwanowicz, L. R., Starliper, C. E., Iwanowicz, D. D., Barbash, P., Hedrick, J. D., et al. (2010). Mortality of centrarchid fishes in the Potomac drainage: survey results and overview of potential contributing factors. Journal of Aquatic Animal Health, 22(3), 190218.

Blazer, V. S., Lilley, J. H., Schill, W. B., Kiryu, Y., Densmore, C. L., Panyawachira, V., et al. (2002). Aphanomyces invadansin Atlantic Menhaden along the East Coast of the United States. J Aquat Anim Health, 14(1), 1-10, doi:10.1577/15488667(2002)014<0001:aiiama>2.0.co;2.

Bouaicha, N., \& Maatouk, I. (2004). Microcystin-LR and nodularin induce intracellular glutathione alteration, reactive oxygen species production and lipid peroxidation in primary cultured rat hepatocytes. Toxicology Letters, 148(1-2), 53-63.

Chen, X. M., Guo, G. L., Sun, L., Yang, Q. S., Wang, G. Q., \& Zhang, D. M. (2017). Modulatory role of L-carnitine against microcystin-LR-induced immunotoxicity and oxidative stress in common carp. Fish Physiology and Biochemistry, 43(4). 1081-1093.

Clark, S. P., Davis, M. A., Ryan, T. P., Searfoss, G. H., \& Hooser, S. B. (2007). Hepatic gene expression changes in mice associated with prolonged sublethal microcystin exposure. Toxicologic Pathology, 35(4), 594-605.

Dawson, R. M. (1998). The toxicology of microcystins. Toxicon, 36(7), 953-932.

Dittmann, E., \& Wiegand, C. (2006). Cyanobacterial toxins--occurrence, biosynthesis and impact on human affairs. Molecular Nutrition \& Food Research, 50(1), 7-17.

$\mathrm{Fu}, \mathrm{J} ., \quad \&$ Xie, P. (2006). The acute effects of microcystin LR on the transcription of nine glutathione S-transferase genes in common carp Cyprinus carpio L. Aquatic Toxicology.

Gauthier, D. T., Latour, R. J., Heisey, D. M., Bonzek, C. F., Gartland, J., Burge, E. J., et al. (2008). Mycobacteriosis-associated mortality in wild striped bass (Morone saxatilis) from Chesapeake Bay, U.S.A. Ecological Applications, 18(7), 1718-1727.

Hahn, C. M., Iwanowicz, L. R., Cornman, R. S., Mazik, P. M., \& Blazer, V. S. (2016). Transcriptome discovery in non-model wild fish species for the development of quantitative transcript abundance assays. Comparative Biochemistry and Physiology Part D Genomics Proteomics, 20, 27-40. 
He, S., Liang, X., Li, R., Li, G., Wang, L., Shen, D. (2010). Molecular Characterization of Heat Shock Protein 70 Genes in the Liver of Three Warm Freshwater Fishes with Differential Tolerance to Microcystin-LR. Journal of Biochemical and Molecular Toxicology, 24(5), 293-302.

Howe, E. A., Sinha, R., Schlauch, D., \& Quackenbush, J. (2011). RNA-Seq Analysis in MeV. Bioinformatics, 27(3209-3210).

Jayaraj, R., Anand, T., \& Rao, P. V. (2006). Activity and gene expression profile of certain antioxidant enzymes to microcystin-LR induced oxidative stress in mice. Toxicology.

Kolpin, D. W., Blazer, V. S., Gray, J. L., Focazio, M. J., Young, J. A., Alvarez, D. A., et al. (2013). Chemical contaminants in water and sediment near fish nesting sites in the Potomac River basin: determining potential exposures to smallmouth bass (Micropterus dolomieu). Science of the Total Environment, 443, 700-716.

Kono, T., Ponpornpisit, A., \& Sakai, M. (2004). The analysis of expressed genes in head kidney of common carp Cyprinus carpio L. stimulated with peptidoglycan. Aquaculture, 235(14), 37-52.

Liang, X., Li, G., He, S., \& Huang, Y. (2007). Transcriptional Responses of Alpha- and RhoClass Glutathione S-Transferase Genes in the Liver of Three Freshwater Fishes Intraperitoneally Injected with Microcystin-LR: Relationship of Inducible Expression and Tolerance. Journal of Biochemical and Molecular Toxicology, 21(5), 289-298.

Li, X., Liu, Y., Song, L., \& Liu, J. (2003). Responses of antioxidant systems in the hepatocytes of common carp (Cyprinus carpio L.) to the toxicity of microcystin-LR. Toxicon, 42(1), 85-89.

Li, Y., Sun, B., Wu, H., Nie, P. (2009). Effects of pure microcystin-LR on the transcription of immune related genes and heat shock proteins in larval stage of zebrafish (Danio rerio). Aquaculture, 289(1-2), 154-160.

Li, Y. Q., Zhang, J., Li, J., \& Sun, L. (2017). First characterization of fish CD22: An inhibitory role in the activation of peripheral blood leukocytes. Veterinary Immunology and Immunopathology, 190, 39-44.

Lushchak, V. I. (2014). Free radicals, reactive oxygen species, oxidative stress and its classification. Chemico-Biological Interactions, 224, 164-175.

Lushchak, V. I. (2016). Contaminant-induced oxidative stress in fish: a mechanistic approach. Fish Physiology and Biochemistry, 42(2), 711-747.

Marie, B., Huet, H., Marie, A., Djediat, C., Puiseux-Dao, S., Catherine, A., et al. (2012). Effects of a toxic cyanobacterial bloom (Planktothrix agardhii) on fish: insights from histopathological and quantitative proteomic assessments following the oral exposure of medaka fish (Oryzias latipes). Aquatic Toxicology, 114-115, 39-48.

Mommsen, T. P., Moon, T. W., \& Walsh, P. J. (1994). Hepatocytes: isolation, maintenance and utilization. In Hochachka, \& Mommsen (Eds.).

Pflugmacher, S., Wiegand, C., A., O., Beattie, K. A., Krause, E., Codd, G. A., et al. (1998). Identification of an enzymatically formed glutathione conjugate of the cyanobacterial 
hepatotoxin microcystin-LR: the first step of detoxication. Biochimica et Biophysica Acta, 1425(3), 527-533.

Pflugmacher, S., Wiegand, C., Oberemm, A., Beattie, K. A., Krause, E., Codd, G. A., et al. (1998). Identification of an enzymatically formed glutathione conjugate of the cyanobacterial hepatotoxin microcystin-LR: the first step of detoxification. Biochimica et biophysica acta, 1425, 527-533.

Rebl, A., Goldammer, T., \& Seyfert, H. M. (2010). Toll-like receptor signaling in bony fish. Veterinary Immunology and Immunopathology, 134(3-4), 139-150.

Robinson, M. D., McCarthy, D. J., \& K., S. G. (2010). edgeR: a Bioconductor package for differential expression analysis of digital gene expression data. Bioinformatics, 26, 139140.

Rogers, E. D., Henry, T. B., Twiner, M. J., Gouffon, J. S., McPherson, J. T., Boyer, G. L., et al. (2011). Global gene expression profiling in larval zebrafish exposed to microcystin-LR and microcystis reveals endocrine disrupting effects of Cyanobacteria. Environmental Science and Technology, 45(5), 1962-1969.

Runnegar, M., Berndt, N., Kong, S.-M., Lee, E. Y. C., \& Zhang, L. (1995). In vivo and In vitro binding of microcystin to protein phosphatases 1 and 2a. Biochemical and Biophysical Research Communications, 216(1), 162-169.

Rymuszka, A., \& Adaszek, L. (2012). Pro- and anti-inflammatory cytokine expression in carp blood and head kidney leukocytes exposed to cyanotoxin stress--an in vitro study. Fish and Shellfish Immunology, 33(2), 382-388.

Rymuszka, A., \& Adaszek, L. (2013). Cytotoxic effects and changes in cytokine gene expression induced by microcystin-containing extract in fish immune cells--an in vitro and in vivo study. Fish and Shellfish Immunology, 34(6), 1524-1532.

Sharp, G. J., Pike, A. W., \& Secombes, C. J. (1991). Leucocyte migration in rainbow trout (Oncorhynchus mykiss [Walbaum]): optimization of migration conditions and responses to host and pathogen (Diphyllobothrium dendriticum [Nitzsch]) derived chemoattractants. Developmental and Comparative Immunology, 15(4), 295-305.

Takumi, S., Komatsu, M., Furukawa, T., Ikeda, R., Sumizawa, T., Akenaga, H., et al. (2010). p53 Plays an important role in cell fate determination after exposure to microcystin-LR. Environmental Health Perspectives, 118(9), 1292-1298.

R Core Development Team. (2017). R: A language and environment for statistical computing. Vienna, Austria: R Foundation for Statistical Computing.

Wang, H., Horbinski, C., Wu, H., Liu, Y., Sheng, S., Liu, J., et al. (2016). NanoStringDiff: a novel statistical method for differential expression analysis based on NanoString nCounter data. Nucleic Acids Research, 44(20).

Wang, L., Liang, X. F., Liao, W. Q., Lei, L. M., \& Han, B. P. (2006). Structural and functional characterization of microcystin detoxification-related liver genes in a phytoplanktivorous fish, Nile tilapia (Oreochromis niloticus). Comparative Biochemistry and Physiology Part C: Pharmacology, Toxicology and Endocrinology, 144(3), 216-227. 
Wang, T., Gorgoglione, B., Maehr, T., Holland, J. W., Vecino, J. L., Wadsworth, S., et al. (2011). Fish Suppressors of Cytokine Signaling (SOCS): Gene Discovery, Modulation of Expression and Function. Journal of Signal Transduction, 2011, 20 pages.

Wei, L., Liu, Y., Zhong, S., Wu, H., Ruan, J., Liu, M., et al. (2018). Transcriptome analysis of grass carp provides insights into the immune-related genes and pathways in response to MC-LR induction. Aquaculture, 488, 207-216.

Wei, L., Sun, B., Song, L., \& Nie, P. (2008). Gene expression profiles in liver of zebrafish treated with microcystin-LR. Environmental Toxicology and Pharmacology, 26(1), 6-12.

WHO (1998). Cyanobacterial toxins: Microcystin-LR in Drinking-water. (2nd ed.). Geneva.

Zhao, Y., Xie, L., \& Yan, Y. (2015). Microcystin-LR impairs zebrafish reproduction by affecting oogenesis and endocrine system. Chemosphere, 120, 115-122.

Zikova, A., Lorenz, C., Lutz, I., Pflugmacher, S., Kloas, W. (2013). Physiological responses of Xenopus laevis tadpoles exposed to cyanobacterial biomass containing microcystin-LR. Aquatic Toxicology, 128-129, 25-33. 


\section{Figures}

Figure 1. Toll-like receptor $1 / 2$ pathway modified from full Danio rerio KEGG TLR pathway (http://www.genome.jp/kegg-bin/show_pathway?dre04620). Gene abbreviations represent HUGO equivalent. Color codes represent transcript activation across all treatment groups. 


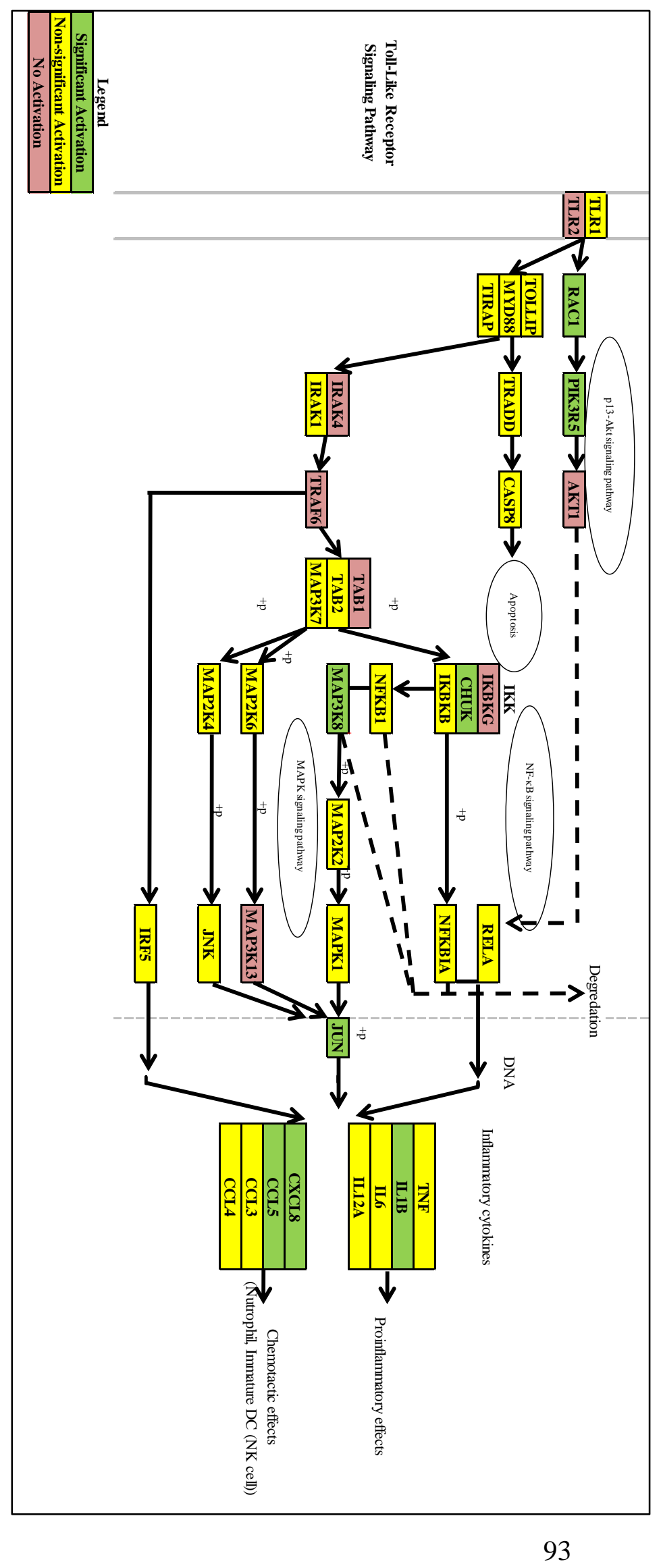


Figure $2 . \log _{2}$ fold changes for each significantly differentially expressed leukocyte transcripts as compared to the $\mathrm{MeOH}$ control. 


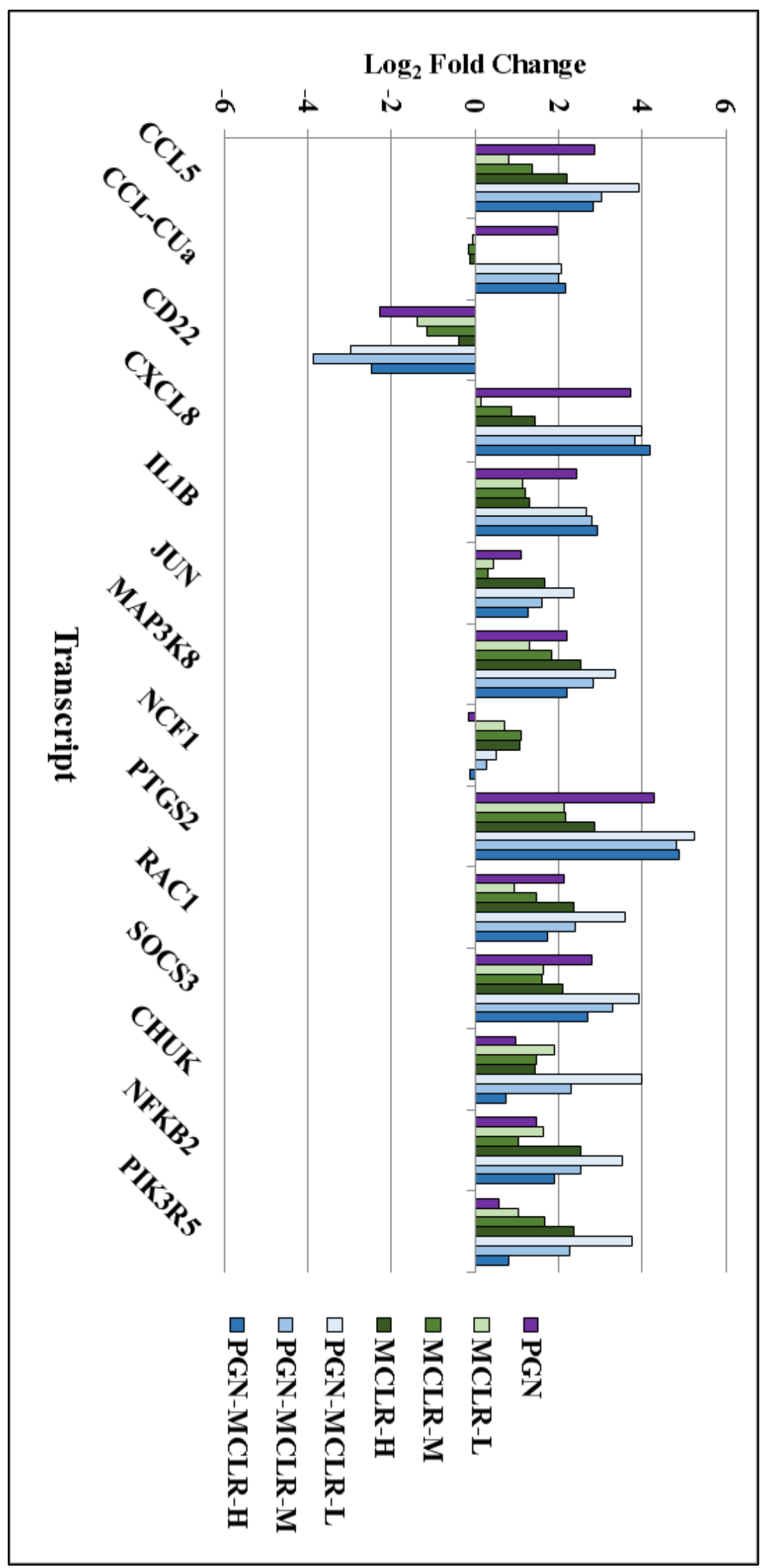




\section{Tables}

Table 1. Description of genes associated with microcystin-LR treatment and expected change in regulation.

\begin{tabular}{|c|c|c|c|c|}
\hline Gene Name & Abbreviation & Category & Citation & $\begin{array}{c}\text { Expected } \\
\text { Association } \\
\text { with } \\
\text { Microcystin } \\
\text { toxins } \\
\end{array}$ \\
\hline Glutathione Peroxidase & $G P X$ & Oxidative stress & Clark et al. 2007 & Positive \\
\hline Glutathione Reductase & $G S R$ & Oxidative stress & Clark et al. 2007 & Positive \\
\hline $\begin{array}{l}\text { Glutathione-S-Transferase } \rho \text { - } \\
\text { class }\end{array}$ & $G S T \rho$ & Oxidative stress & Liang et al. 2007 & Positive \\
\hline $\begin{array}{l}\text { Glutathione-S-Transferase } \theta \text { - } \\
\text { class }\end{array}$ & GST $\theta$ & Oxidative stress & $\begin{array}{l}\text { Fu and Xie } 2006, X . \\
\text { Li et al. } 2003\end{array}$ & No effect \\
\hline Superoxide Dismutase & $S O D$ & Oxidative stress & Clark et al. 2007 & Negative \\
\hline $\begin{array}{l}\text { Proliferating Cell Nuclear } \\
\text { Antigen }\end{array}$ & PCNA & Neoplasia & Wei et al. 2008 & Positive \\
\hline $\begin{array}{l}\text { Cytochrome P450, family } 1 \text {, } \\
\text { member A1 }\end{array}$ & CYP1A & $\begin{array}{l}\text { Endocrine } \\
\text { distuption }\end{array}$ & Zikova et al. 2013 & No effect \\
\hline Vitellogenin & $v t g$ & $\begin{array}{l}\text { Endocrine } \\
\text { distuption }\end{array}$ & Rogers et al. 2011 & Positive \\
\hline Heat Shock Protein 70 & hsp70 & Oxidative stress & He et al. 2010 & Positive \\
\hline Heat Shock Protein 90 & hsp90 & Oxidative stress & Y. Li et al. 2009 & Positive \\
\hline Interleukin-1 $\beta$ & $I L-1 \beta$ & $\begin{array}{l}\text { Pro-inflamatory } \\
\text { Cytokine }\end{array}$ & $\begin{array}{l}\text { Rymuszka and } \\
\text { Adaszek } 2012 \\
\end{array}$ & Negative \\
\hline Catalase & $C A T$ & Oxidative stress & Clark et al. 2007 & Negative \\
\hline Transforming growth factor $\beta$ & TGF $\beta$ & Neoplasia & $\begin{array}{l}\text { Rymuszka and } \\
\text { Adaszek } 2012\end{array}$ & Positive \\
\hline
\end{tabular}


Table 2. Specific primers used in NanoString nCounter liver custom CodeSet. Tm CP and Tm

$\mathrm{RP}$ represents the melting temperatures of the capture and reporter probe, respectively.

\begin{tabular}{|c|c|c|c|c|c|c|}
\hline $\begin{array}{c}\text { Transcript } \\
\text { Name }\end{array}$ & Classification & $\begin{array}{l}\text { HUGO Gene } \\
\text { Abbreviation }\end{array}$ & Abbreviation & $\begin{array}{l}\mathbf{T m} \\
\mathbf{C P}\end{array}$ & $\begin{array}{l}\mathbf{T m} \\
\mathbf{R P}\end{array}$ & Primer \\
\hline $\begin{array}{l}17 \mathrm{~B} \\
\text { Hydroxyste } \\
\text { roid } \\
\text { Dehydroge } \\
\text { nase } \\
\end{array}$ & $\begin{array}{l}\text { Endocrine } \\
\text { Disruption }\end{array}$ & HSD17B3 & 17BHD & 83 & 84 & $\begin{array}{c}\text { CATCCTCAACATCTCGTCTGCC } \\
\text { AGTGGGATGTACCCTGTTCCT } \\
\text { CTCCTCACTGTCTACTCTGCCT } \\
\text { CCAAGGCGTTTGTGGACTTCTT } \\
\text { CTCCCGAGGACTG } \\
\end{array}$ \\
\hline $\begin{array}{c}40 \mathrm{~S} \\
\text { ribosomal } \\
\text { protein S12 }\end{array}$ & Housekeeper & $\begin{array}{c}\text { Micropterus_ } \\
0108\end{array}$ & RPS12 & 86 & 85 & $\begin{array}{c}\text { CTCCCTGATCCACGATGGCCTT } \\
\text { GCCCGTGGTATCCGTGAGGCC } \\
\text { ACAAAGGCCCTGGACAAGCGT } \\
\text { CAGGCTCATCTCTGCGCTCTG } \\
\text { GCTGCCAACTGCGAT } \\
\end{array}$ \\
\hline $\begin{array}{l}\text { Androgen } \\
\text { Receptor } \alpha\end{array}$ & $\begin{array}{l}\text { Endocrine } \\
\text { Disruption }\end{array}$ & ARA & $\mathrm{AR} \alpha$ & 85 & 86 & $\begin{array}{c}\text { GACTGCACCATCGACAAACTG } \\
\text { AGGCGGAAAAACTGCGCCTCG } \\
\text { TGCCGTTTAAAGAGATGCTTC } \\
\text { ATGTCGGGAATGAGCCTTAAA } \\
\text { GGTCGCAGGCTAAAGG } \\
\end{array}$ \\
\hline $\begin{array}{l}\text { Androgen } \\
\text { Receptor } \beta\end{array}$ & $\begin{array}{l}\text { Endocrine } \\
\text { Disruption }\end{array}$ & ARB & $\mathrm{AR} \beta$ & 83 & 84 & $\begin{array}{c}\text { ATTAACTATCGAATGACCACC } \\
\text { AACTGCTCTCAGAGGTTCTAC } \\
\text { CAACTCACCCGAGTCCTGGAC } \\
\text { TCTCTCCAGATGACGGTCAAG } \\
\text { AAGCTCCATCAGTTTA } \\
\end{array}$ \\
\hline $\begin{array}{l}\text { Apolipopro } \\
\text { tein A1 }\end{array}$ & $\begin{array}{l}\text { Endocrine } \\
\text { Disruption }\end{array}$ & APOA1 & APA1 & 79 & 84 & $\begin{array}{c}\text { TTTAGCCGCTGAAATCAAGGA } \\
\text { TAAGTTCCAAGCTATCTTCGA } \\
\text { GGCCATCGCTGCTACCGTCAC } \\
\text { CAAGAGCTAAATCCTCTCCAC } \\
\text { CCTGTCCCTGTAATTA } \\
\end{array}$ \\
\hline $\begin{array}{c}\text { Aryl } \\
\text { Hydrocarbo } \\
\text { n Receptor }\end{array}$ & Contaminants & AHR & AHR & 85 & 83 & $\begin{array}{c}\text { CGCCGCCTCAGCTCGCCCTGTT } \\
\text { CGCCATCGCCACACCCCTCCA } \\
\text { GCCTCCAGCCATCCTTGAAAT } \\
\text { CAGGACGAGGAACATGATTTT } \\
\text { CAGGACCAAACACAA }\end{array}$ \\
\hline $\begin{array}{c}\text { B-cell } \\
\text { lymphoma } \\
2\end{array}$ & Neoplasia & BCL2 & BCL2 & 85 & 82 & $\begin{array}{c}\text { GATGACAGAGTACTTAAACGG } \\
\text { ACCTCTGAACAGCTGGATACA } \\
\text { AGATAACGGGGGATGGGTAG } \\
\text { GTCTGATTCCGTGTAGTTGAG } \\
\text { CGCTTTGCAGTTGTGTG }\end{array}$ \\
\hline $\begin{array}{c}\text { Compleme } \\
\text { nt } \\
\text { Component } \\
3\end{array}$ & $\begin{array}{l}\text { Immune } \\
\text { Response }\end{array}$ & $\begin{array}{c}\text { GDQU01000 } \\
040\end{array}$ & $\mathrm{C} 3$ & 79 & 84 & $\begin{array}{c}\text { CAATCTTGGATATTGGCTTGCT } \\
\text { AACTGGCTTTACTGCTAACAC } \\
\text { AAATGACCTGGACTTACTGTC } \\
\text { CAAAGGACGTGCCCGCACTAT } \\
\text { TGCAAAATATGAGAT } \\
\end{array}$ \\
\hline
\end{tabular}




\begin{tabular}{|c|c|c|c|c|c|c|}
\hline $\begin{array}{c}\text { Transcript } \\
\text { Name }\end{array}$ & Classification & $\begin{array}{l}\text { HUGO Gene } \\
\text { Abbreviation }\end{array}$ & Abbreviation & $\begin{array}{l}\text { Tm } \\
\text { CP }\end{array}$ & $\begin{array}{l}\text { Tm } \\
\text { RP }\end{array}$ & Primer \\
\hline Catalase & $\begin{array}{l}\text { Endocrine } \\
\text { Disruption }\end{array}$ & CAT & CAT & 84 & 82 & $\begin{array}{c}\text { GCCCAGCTCTTCATCCAGAAA } \\
\text { CGCATGGTCGAGAATTTGAAG } \\
\text { GCTGTCCATCCACACTATGGA } \\
\text { AACCGAGTTCAGGCTCTTCTT } \\
\text { GACAAGTACAATGTGG }\end{array}$ \\
\hline $\begin{array}{c}\text { Choriogeni } \\
n\end{array}$ & $\begin{array}{l}\text { Endocrine } \\
\text { Disruption }\end{array}$ & HSD3B & CHG & 84 & 80 & $\begin{array}{l}\text { GAAAGCAAAAATGTGAGCAG } \\
\text { CCTTCCTCTTGACCCTCTATGG } \\
\text { GTCCCATTTTCTGCGGTTAAGG } \\
\text { TGGCTGAGGAATTCTTATACTT } \\
\text { CACCCTGAAACTCA } \\
\end{array}$ \\
\hline $\begin{array}{l}\text { C-reactive } \\
\text { protein-like }\end{array}$ & $\begin{array}{c}\text { Stress } \\
\text { Response }\end{array}$ & $\begin{array}{c}\text { GDQU01027 } \\
741\end{array}$ & CRP & 81 & 86 & $\begin{array}{c}\text { CAGCTGTGGTTTGATGGACAA } \\
\text { CCATCAATAAGGAAATATATC } \\
\text { AGCTCTGGATCAAGCATCAAA } \\
\text { GGGCCCACTATTATCACCTTA } \\
\text { GGACAGGAGCAGGATT }\end{array}$ \\
\hline $\begin{array}{l}\text { Cytochrom } \\
\text { e P450, } \\
\text { family } 1 \text {, } \\
\text { member A1 }\end{array}$ & $\begin{array}{l}\text { Endocrine } \\
\text { Disruption }\end{array}$ & CYP1A & CYP1A & 83 & 78 & $\begin{array}{c}\text { CAGCTCAACACTGTTATGAAG } \\
\text { GCTGAAGGCAGTTTCGACCCA } \\
\text { TTCCGCTACATCGTTGTCTCTG } \\
\text { TTGCTAATGTGATCTGTGCCAT } \\
\text { GTGCTTTGGCCGAC }\end{array}$ \\
\hline $\begin{array}{l}\text { Cytochrom } \\
\text { e P450, } \\
\text { family 3, } \\
\text { subfamily } \\
\text { A }\end{array}$ & $\begin{array}{l}\text { Endocrine } \\
\text { Disruption }\end{array}$ & CYP3A & CYP3A & 79 & 82 & $\begin{array}{c}\text { TTCGGCACTATGCTGGCATAT } \\
\text { AAAAAGGGATTCATGCACTTT } \\
\text { GATTCGGAGTGCTTCAAGAAA } \\
\text { TATGGGAAAACATGGGGCATT } \\
\text { TTTGATGGCCGTCAGC }\end{array}$ \\
\hline $\begin{array}{l}\text { Elongation } \\
\text { Factor } 1 \alpha\end{array}$ & Housekeeper & EF1A & $\mathrm{EF} 1 \alpha$ & 85 & 85 & $\begin{array}{c}\text { AGATCAACGCAGGTTACGCAC } \\
\text { CTGTGCTGGATTGCCACACAG } \\
\text { CTCACATTGCCTGCAAGTTCA } \\
\text { AGGAGCTCATCGAGAAGATCG } \\
\text { ACCGTCGTTCTGGCAA } \\
\end{array}$ \\
\hline $\begin{array}{l}\text { Epidermal } \\
\text { Growth } \\
\text { Factor } \\
\text { Receptor }\end{array}$ & Neoplasia & EGFR & EGFR & 86 & 84 & $\begin{array}{c}\text { GGTCTGTGGGTTCCAGAAGGA } \\
\text { GAGGATGTGAAGATCCCAGTG } \\
\text { GCCATCAAAGTTTTGAGAGAG } \\
\text { GCCACATCACCAAAAGCAAAC } \\
\text { AAAGAGATCTTGGACG } \\
\end{array}$ \\
\hline $\begin{array}{c}\text { Epoxide } \\
\text { Hydrolase } 1\end{array}$ & Contaminants & EH & EH1 & 83 & 84 & $\begin{array}{c}\text { GATAGACCAGACTCGCCCTGT } \\
\text { CCCTTCACTAGAGGATAGCCA } \\
\text { GTTTAATTATGGCTTCAATTCC } \\
\text { CAGTACCTGCAGAAGGTGGTC } \\
\text { TCTTACTGGAGAAAT } \\
\end{array}$ \\
\hline $\begin{array}{l}\text { Estrogen } \\
\text { Receptors } \alpha\end{array}$ & $\begin{array}{l}\text { Endocrine } \\
\text { Disruption }\end{array}$ & ESRA1 & $\mathrm{ER} \alpha$ & 85 & 85 & $\begin{array}{c}\text { CTCTCCCACCATCAGGCACAT } \\
\text { GAGCGAACAAAGGTAATGGA } \\
\text { GCATCTCTACAGCATGAAGTG } \\
\text { CAAGAACAAAGTGCCTCTGTA } \\
\text { CGACCTTCTGCTGGAGA }\end{array}$ \\
\hline
\end{tabular}




\begin{tabular}{|c|c|c|c|c|c|c|}
\hline $\begin{array}{c}\text { Transcript } \\
\text { Name }\end{array}$ & Classification & $\begin{array}{l}\text { HUGO Gene } \\
\text { Abbreviation }\end{array}$ & Abbreviation & $\begin{array}{l}\mathbf{T m} \\
\mathbf{C P}\end{array}$ & $\begin{array}{l}\text { Tm } \\
\text { RP }\end{array}$ & Primer \\
\hline $\begin{array}{c}\text { Estrogen } \\
\text { Receptors } \\
\beta 1\end{array}$ & $\begin{array}{l}\text { Endocrine } \\
\text { Disruption }\end{array}$ & ESRB1 & $\mathrm{ER} \beta 1$ & 85 & 85 & $\begin{array}{c}\text { GCCTGAGCAGAGAAGAGGGG } \\
\text { AGCTGTGTCCAGGGCTTCGCA } \\
\text { GAGATCTTTGATATGCTGATA } \\
\text { GCTGCCACGTCCAGGGTGAGA } \\
\text { GAGCTCAAGCTCCAGAG }\end{array}$ \\
\hline $\begin{array}{l}\text { Estrogen } \\
\text { Receptors } \\
\quad \beta 2\end{array}$ & $\begin{array}{l}\text { Endocrine } \\
\text { Disruption }\end{array}$ & ESRB2 & ER $\beta 2$ & 85 & 86 & $\begin{array}{c}\text { CTGCAGCTCCATCCTCGGTTGT } \\
\text { AACAAGCCGCTGGGGAAGAG } \\
\text { ATTAGAGGAAGGAGTGGAAG } \\
\text { GCGTGAACTCCTCCTTGTGTTC } \\
\text { TTCTGCGGTAGGGAAA }\end{array}$ \\
\hline $\begin{array}{l}\text { Eukaryotic } \\
\text { Translation } \\
\text { Initiation } \\
\text { Factor 3D }\end{array}$ & Housekeeper & EIF3D & ETIF3D & 85 & 84 & $\begin{array}{c}\text { ACATGACTCAGTTCAACATGC } \\
\text { AGACGCTACCTAAGAGCGCCA } \\
\text { AGCAAAAGGAGAGGGATCGT } \\
\text { ATGCGCCTGCAGAAGAAGTTC } \\
\text { CAAAAGCAGTTTGGTGT }\end{array}$ \\
\hline $\begin{array}{l}\text { Glucocortic } \\
\text { oid } \\
\text { Receptor }\end{array}$ & $\begin{array}{c}\text { Stress } \\
\text { Response }\end{array}$ & GR & GR & 82 & 84 & $\begin{array}{c}\text { GCAGATGCTGAAGATCTGTAA } \\
\text { TGAGTTTGTCAGACTGCAGGT } \\
\text { GTCCTATGATGAGTACCTGTG } \\
\text { CATGAAGGTCCTGTTACTGCT } \\
\text { CAGTACAGTACCGAAA } \\
\end{array}$ \\
\hline $\begin{array}{c}\text { Glucokinas } \\
\mathrm{e}\end{array}$ & Neoplasia & GCK & GLK & 83 & 81 & $\begin{array}{c}\text { TACTCTATTCCTGAAGATGCC } \\
\text { ATGACAGGCACTGCCGAAATG } \\
\text { CTATTTGATTACATAGCAGAG } \\
\text { TGCATGTCAGACTTCTTGGAC } \\
\text { AAACATCATCTCAAGC }\end{array}$ \\
\hline $\begin{array}{l}\text { Glutathione } \\
\text { Peroxidase } \\
\quad 1\end{array}$ & $\begin{array}{c}\text { Stress } \\
\text { Response }\end{array}$ & GPX & GPX & 83 & 83 & $\begin{array}{c}\text { GAACGAGCTTCACAGTCGTTA } \\
\text { CACTGCCAAGGGACTCGTTAT } \\
\text { TCTGGGTGTGCCCTGCAATCA } \\
\text { GTTTGGACATCAGGAGAACTG } \\
\text { CAAGAATGATGAAATT } \\
\end{array}$ \\
\hline $\begin{array}{l}\text { Glutathione } \\
\text { Reductase }\end{array}$ & $\begin{array}{c}\text { Stress } \\
\text { Response }\end{array}$ & GSR & GSR & 83 & 83 & $\begin{array}{c}\text { TCTGCCAAAGCGCAGTGTGAT } \\
\text { TGTCGGTGCGGGTTATATTGC } \\
\text { AGTGGAGATGGCAGGCATCCT } \\
\text { TTCCACCCTGGGGTCCAAAAC } \\
\text { ATCCCTCATTATTCGA }\end{array}$ \\
\hline $\begin{array}{l}\text { Glutathione } \\
\text { S- } \\
\text { Transferase } \\
\text { theta-1 }\end{array}$ & $\begin{array}{c}\text { Stress } \\
\text { Response }\end{array}$ & GST & GST $\theta$ & 84 & 83 & $\begin{array}{c}\text { CCTGCTGGAGGCGAAATTCCT } \\
\text { GCAGAACAAACCGTTTATCAT } \\
\text { CGGCGACAAAATCTCTCTGGC } \\
\text { TGATCTGGTGGCTATAGTTGA } \\
\text { GATCATGCAGCCTGTT } \\
\end{array}$ \\
\hline $\begin{array}{l}\text { GST A-like } \\
\text { (rho-class) }\end{array}$ & $\begin{array}{c}\text { Stress } \\
\text { Response }\end{array}$ & $\begin{array}{c}\text { GDQU01079 } \\
959\end{array}$ & GST $\rho$ & 79 & 82 & $\begin{array}{c}\text { TCGTGTCTGTCAGATATTTAAC } \\
\text { AAACACAGGCAATGTTGGTCT } \\
\text { GTGCAGCATGTGATGTTTGCA } \\
\text { GGGTAACAGGCATAGGTTGCA } \\
\text { GGCCAAATGTAATGT }\end{array}$ \\
\hline
\end{tabular}




\begin{tabular}{|c|c|c|c|c|c|c|}
\hline $\begin{array}{c}\text { Transcript } \\
\text { Name }\end{array}$ & Classification & $\begin{array}{l}\text { HUGO Gene } \\
\text { Abbreviation }\end{array}$ & Abbreviation & $\begin{array}{l}\text { Tm } \\
\text { CP }\end{array}$ & $\begin{array}{l}\mathbf{T m} \\
\mathbf{R P}\end{array}$ & Primer \\
\hline haptoglobin & $\begin{array}{c}\text { Stress } \\
\text { Response }\end{array}$ & $\begin{array}{c}\text { GDQU01003 } \\
865\end{array}$ & HP & 83 & 79 & $\begin{array}{c}\text { TCTACAGCGACCTCTTTGGAG } \\
\text { GCATCAGCTTCCGCCCGTTGT } \\
\text { GAAATTCCCAGGTACACTTTA } \\
\text { GGAATGACGGGATCTTTTCCC } \\
\text { TGAATATCCTGTCGAC } \\
\end{array}$ \\
\hline $\begin{array}{l}\text { Heat Shock } \\
\text { Proteins } 71\end{array}$ & $\begin{array}{c}\text { Stress } \\
\text { Response }\end{array}$ & HSP71 & HSP71 & 80 & 84 & $\begin{array}{c}\text { TCATTGCATTGTTTGCGACACA } \\
\text { ACTGAGGAGCAACTTGTTGGC } \\
\text { ACAGTTGAGCTGTCAGTTCAC } \\
\text { ATGTAAAGTGTCTGGTATACT } \\
\text { GAGAGGTCACTGCCT }\end{array}$ \\
\hline $\begin{array}{l}\text { Heat Shock } \\
\text { Proteins } \\
\text { 90B }\end{array}$ & $\begin{array}{c}\text { Stress } \\
\text { Response }\end{array}$ & HSP90A & HSP90A & 81 & 84 & $\begin{array}{c}\text { ACATCAAGCTGTATGTCAGGA } \\
\text { GGGTCTTTATTATGGACAACT } \\
\text { GTGAAGAGCTCATTCCAGAGT } \\
\text { ACCTGAACTTTGTCCGTGGTGT } \\
\text { GGTGGACTCTGAGGA }\end{array}$ \\
\hline Hepcidin 1 & $\begin{array}{l}\text { Endocrine } \\
\text { Disruption }\end{array}$ & HAMP1 & HEP1 & 82 & 80 & $\begin{array}{c}\text { TCTCATGGGTGTCAGGCCACC } \\
\text { AAAAGAGCACCACAATATCTT } \\
\text { CACTTTATTCTTCAGCTCTAAC } \\
\text { GATGGATGGCGATTGTCTGGG } \\
\text { CAAGTGGATTTCTTC } \\
\end{array}$ \\
\hline Hepcidin 2 & $\begin{array}{l}\text { Endocrine } \\
\text { Disruption }\end{array}$ & HAMP2 & HEP2 & 85 & 81 & $\begin{array}{c}\text { ACTCAGAGGAGCTGACAAGAG } \\
\text { TCACCAAAGAGTCAAAGGATT } \\
\text { GAACAACTTAAACCTCTCAAA } \\
\text { CCCTTCTAAGATGAAGACACT } \\
\text { CAGTGTTGCAGTTGCA } \\
\end{array}$ \\
\hline $\begin{array}{l}\text { Hypoxanthi } \\
\text { ne } \\
\text { Phosphorib } \\
\text { osyltransfer } \\
\text { ase 1 } \\
\end{array}$ & Housekeeper & HPRT1 & HPRT1 & 83 & 83 & $\begin{array}{c}\text { ACTTCATTCGCCTCAAGAGCT } \\
\text { ACTGTAACGACCAGTCGACAG } \\
\text { GTGAAATCAAAGTAATCGGTG } \\
\text { GGGATGACCTGTGTACGTTGA } \\
\text { CAGGCAAGAATGTCTT } \\
\end{array}$ \\
\hline $\begin{array}{l}\text { Interleukin- } \\
\qquad 1 \beta\end{array}$ & $\begin{array}{l}\text { Immune } \\
\text { Response }\end{array}$ & $\begin{array}{c}\text { GDQU01054 } \\
274\end{array}$ & IL1b & 83 & 81 & $\begin{array}{c}\text { ATCGTCGCCATAGAGAGGTTT } \\
\text { AAGGGCAGCAGATGCATTGAC } \\
\text { TCTGAAAACCTGCTCAACTTC } \\
\text { ATGCTGGAGAGCTTAGTGGAA } \\
\text { GAGCATATAGTGTTTG } \\
\end{array}$ \\
\hline $\begin{array}{l}\text { Insulin-like } \\
\text { Growth } \\
\text { Factor } 1\end{array}$ & $\begin{array}{l}\text { Endocrine } \\
\text { Disruption }\end{array}$ & IGF1 & IGF1 & 83 & 84 & $\begin{array}{c}\text { CGGAGACCCGTGGGGATGTCT } \\
\text { AGCGCTCTCTCCTTTCAGTGGC } \\
\text { ATTTATGTGATGTCTTCAAGA } \\
\text { GTGCGATGTGCTGTATCTCCTG } \\
\text { TAGCCACACCCTCT } \\
\end{array}$ \\
\hline $\begin{array}{l}\text { Largemout } \\
\text { h Bass } \\
\text { Virus MCP }\end{array}$ & Virus & LMBV MCP & LMBV MCP & 85 & 86 & $\begin{array}{c}\text { AGCAGTTTAACACTGCTTTCCT } \\
\text { GGATGCCTGGAACGAGTACAC } \\
\text { CATGCCCGAGGCCAAGCGCAT } \\
\text { CGGGTATTACAACATGATTGG } \\
\text { CAACACTAGCGATCT }\end{array}$ \\
\hline
\end{tabular}




\begin{tabular}{|c|c|c|c|c|c|c|}
\hline $\begin{array}{c}\text { Transcript } \\
\text { Name }\end{array}$ & Classification & $\begin{array}{l}\text { HUGO Gene } \\
\text { Abbreviation }\end{array}$ & Abbreviation & $\begin{array}{l}\mathbf{T m} \\
\mathbf{C P}\end{array}$ & $\begin{array}{l}\text { Tm } \\
\text { RP }\end{array}$ & Primer \\
\hline $\begin{array}{l}\text { Metallothio } \\
\text { nein }\end{array}$ & Contaminants & MT1 & MT & 85 & 75 & $\begin{array}{c}\text { CAGCGCTCTACTGCCCTTGTG } \\
\text { ATGGCGCCTGTGTGAACAACT } \\
\text { AATGACTAACTGCACATGTCT } \\
\text { ACATAAAATGTATTTTGTACTC } \\
\text { GTCTCAGCGTTGCAG }\end{array}$ \\
\hline $\begin{array}{l}\text { Proliferatin } \\
\text { g Cell } \\
\text { Nuclear } \\
\text { Antigen }\end{array}$ & Neoplasia & PCNA & PCNA & 84 & 84 & $\begin{array}{c}\text { CATCACACTCAGAGCAGAAGA } \\
\text { CAATGCAGACACACTCGCACT } \\
\text { TGTGTTTGAGACGATCAACCA } \\
\text { GGAGAAGGTCTCAGATTATGA } \\
\text { GATGAAATTGATGGAC }\end{array}$ \\
\hline $\begin{array}{l}\text { Ribosomal } \\
\text { Protein L8 }\end{array}$ & Housekeeper & RPL18 & RPL8 & 85 & 85 & $\begin{array}{c}\text { TTCTCCTCTGCAAACAGAGCT } \\
\text { GTTGTTGGTGTGGTAGCTGGA } \\
\text { GGTGGTCGTATTGACAAGCCC } \\
\text { ATCCTGAAGGCTGGTCGTGCC } \\
\text { TACCATAAGTACAAGG } \\
\end{array}$ \\
\hline $\begin{array}{l}\text { Serum } \\
\text { amyloid A- } \\
\quad 5\end{array}$ & $\begin{array}{l}\text { Immune } \\
\text { Response }\end{array}$ & $\begin{array}{c}\text { GDQU01041 } \\
317\end{array}$ & SAA-5 & 83 & 81 & $\begin{array}{c}\text { TCAGAGTATGCTCGCCACATA } \\
\text { TCACGAGTTCCTTGAGCAGCT } \\
\text { TCAACAGGAAACCAGTACCAC } \\
\text { TGGGCATTGGTTTCCACAATT } \\
\text { AGAACCAGAACAATTC } \\
\end{array}$ \\
\hline $\begin{array}{c}\text { Serum } \\
\text { amyloid P }\end{array}$ & $\begin{array}{l}\text { Immune } \\
\text { Response }\end{array}$ & $\begin{array}{c}\text { GDQU01051 } \\
042\end{array}$ & SAP & 80 & 83 & $\begin{array}{c}\text { TTCCGTGTGCTCGGGTTTCCAT } \\
\text { TGACCCACAGCTGAGCGACTC } \\
\text { CTGTTTTCCCTTCCCACGTAGC } \\
\text { GCACACTGAATTGAAGACATT } \\
\text { GGGATTATCCGGCA } \\
\end{array}$ \\
\hline $\begin{array}{l}\text { Superoxide } \\
\text { Dismutase }\end{array}$ & $\begin{array}{c}\text { Stress } \\
\text { Response }\end{array}$ & SOD & SOD & 79 & 83 & $\begin{array}{c}\text { ATGGTGTTTAAAGCTGTTTGTG } \\
\text { TTTTAAAAGGAGCCGGAGAGA } \\
\text { CCACCGGGACCGTTTATTTTG } \\
\text { AGCAGGAGGGCGATTCAGACC } \\
\text { CTGTGAAGGTGACAG }\end{array}$ \\
\hline $\begin{array}{l}\text { Tata Box } \\
\text { Binding } \\
\text { Protein }\end{array}$ & Housekeeper & TBP & TBP & 82 & 84 & $\begin{array}{c}\text { GTTAGCTGCCAGAAAATACGC } \\
\text { TCGTGTGGTGCAGAAGCTCGG } \\
\text { TTTTCCTGCAAAGTTCCTGGAC } \\
\text { TTCAAGATTCAGAACATGGTG } \\
\text { GGAAGCTGCGACGTG } \\
\end{array}$ \\
\hline $\begin{array}{l}\text { Thyroid } \\
\text { Hormone } \\
\text { Receptor } \beta\end{array}$ & $\begin{array}{l}\text { Endocrine } \\
\text { Disruption }\end{array}$ & THRB & THR $\beta$ & 83 & 84 & $\begin{array}{c}\text { TGCATTACCTGTGAAGGTTGC } \\
\text { AAGGGTTTCTTCAGGCGGACG } \\
\text { ATCCAGAAGAATCTCAACCCT } \\
\text { ACCTACGCCTGTAAGTATGAG } \\
\text { GCGAAATGCGTCATCG }\end{array}$ \\
\hline Transferrin & $\begin{array}{l}\text { Immune } \\
\text { Response }\end{array}$ & $\begin{array}{c}\text { GDQU01000 } \\
776\end{array}$ & $\mathrm{TF}$ & 83 & 83 & $\begin{array}{c}\text { ATCAGAGCAAGAATATCGGAA } \\
\text { ATGTTTGGATCTGGTAGCCAA } \\
\text { AGCGCCCGCGTTCTCCTGCGT } \\
\text { GAAGAAGGAAAACACCATCG } \\
\text { ACTGCATCACTGCTATT }\end{array}$ \\
\hline
\end{tabular}




\begin{tabular}{|c|c|c|c|c|c|c|}
\hline $\begin{array}{c}\text { Transcript } \\
\text { Name }\end{array}$ & Classification & $\begin{array}{l}\text { HUGO Gene } \\
\text { Abbreviation }\end{array}$ & Abbreviation & $\begin{array}{l}\text { Tm } \\
\text { CP }\end{array}$ & $\begin{array}{l}\text { Tm } \\
\text { RP }\end{array}$ & Primer \\
\hline $\begin{array}{l}\text { Transformi } \\
\text { ng Growth } \\
\text { Factor } \beta\end{array}$ & Neoplasia & TGFB & TGF $\beta$ & 83 & 84 & $\begin{array}{c}\text { AATAACACAGAGAACACCAA } \\
\text { GACCTCCAAAAGCATCCCGAT } \\
\text { GTTCTTCAGCATCTCTAACATA } \\
\text { CGGGAAAGTGTGGGGGATTCC } \\
\text { AGTTTGCTGACCAGTG }\end{array}$ \\
\hline $\begin{array}{c}\text { Type I } \\
\text { Deiodinase }\end{array}$ & $\begin{array}{l}\text { Endocrine } \\
\text { Disruption }\end{array}$ & DIO1 & DIO1 & 86 & 85 & $\begin{array}{c}\text { ACTGTCTGGAGCAGTCCACAG } \\
\text { TGCAGAATACAAACTATGAGT } \\
\text { AGGACGACTGAGACCGACGAT } \\
\text { GCAGCGTTGTGCGTAATGAAG } \\
\text { GGTAGTCTGGAATAAA }\end{array}$ \\
\hline $\begin{array}{c}\text { Type II } \\
\text { Deiodinase }\end{array}$ & $\begin{array}{l}\text { Endocrine } \\
\text { Disruption }\end{array}$ & $\mathrm{DIO} 2$ & $\mathrm{DIO} 2$ & 79 & 75 & $\begin{array}{c}\text { GCTGTGAAATTGTGAGTTCAC } \\
\text { CACCAAGGAGCAAGCATGTTT } \\
\text { TTGCAAAGACTGATGGTCTAT } \\
\text { TTATCGACAGTATGCCTGTTTT } \\
\text { GCTATATGATAGGAC } \\
\end{array}$ \\
\hline $\begin{array}{c}\text { Vitellogeni } \\
n\end{array}$ & $\begin{array}{l}\text { Endocrine } \\
\text { Disruption }\end{array}$ & VTG & VTG & 80 & 84 & $\begin{array}{c}\text { CATTGGTAATCATGTTGCGCT } \\
\text { GAGGTTCATCAAGGAGCACTT } \\
\text { CCTCGCTGGTGAGCTATCTTTT } \\
\text { GCTGAAACTGCTCAAGCCCTG } \\
\text { CTGGCATCTGTTCAC } \\
\end{array}$ \\
\hline $\begin{array}{l}\text { Warm } \\
\text { Temperatur } \\
\text { e } \\
\text { Acclimatio } \\
\text { n Protein } \\
65 \\
\end{array}$ & $\begin{array}{c}\text { Stress } \\
\text { Response }\end{array}$ & WAP65 & WAP65 & 82 & 83 & $\begin{array}{c}\text { TGGATGCTGTTGCAGTGAACG } \\
\text { AAGAGGGAATCCCGTACTTTT } \\
\text { TCAAGGGTGACCATCTGTTCA } \\
\text { AGGGCTTCCATGGCAAAGCAG } \\
\text { AGCTGTCCAATAATTC }\end{array}$ \\
\hline $\begin{array}{c}\text { Zona } \\
\text { Pellucida } 3\end{array}$ & $\begin{array}{l}\text { Endocrine } \\
\text { Disruption }\end{array}$ & $\mathrm{ZP} 3$ & $\mathrm{ZP} 3$ & 84 & 82 & $\begin{array}{c}\text { CTGTGTGGCCACTGCTGTCCCT } \\
\text { GATATAAATGCAGTCCCCAGA } \\
\text { TATTCCTTCATTGAGAACCATG } \\
\text { GGTGTTTGATTGATGCCAAGC } \\
\text { TAACCCAGTCCAGT }\end{array}$ \\
\hline
\end{tabular}


Table 3. Specific primers used in NanoString nCounter leukocyte custom CodeSet. Tm CP and

Tm RP represents the melting temperatures of the capture and reporter probe, respectively.

\begin{tabular}{|c|c|c|c|c|c|}
\hline Transcript Name & $\begin{array}{l}\text { Classification } \\
\text { /Association }\end{array}$ & $\begin{array}{l}\text { HUGO } \\
\text { Gene } \\
\text { Abbrev } \\
\text { iation }\end{array}$ & $\begin{array}{l}\text { Tm } \\
\text { CP }\end{array}$ & $\begin{array}{l}\mathbf{T m} \\
\mathbf{R P}\end{array}$ & Primer \\
\hline $\begin{array}{l}\text { RAC-alpha serine } \\
\text { threonine- kinase }\end{array}$ & TLR1/2 & AKT1 & 84 & 82 & $\begin{array}{l}\text { AGGTCTACCTGACCAAAATCAGACACAAA } \\
\text { GTGACTATGCACGACTTTGAATACCTCAA } \\
\text { ACTCCTGGGAAAAGGCACTTTTGGCAAAG } \\
\text { TTATCCTGGTAAA }\end{array}$ \\
\hline caspase 8 & TLR1/2 & CASP8 & 80 & 84 & $\begin{array}{l}\text { TAAAAGACCTCAGCGGAAGGGATTTTTTT } \\
\text { GCTGATGATGCCTTGGTGGTATGCGTGCT } \\
\text { TTCCCACGGAGAAAAGGGTTGTGTCTTTG } \\
\text { GGACGGATGAGAA }\end{array}$ \\
\hline MIP1alpha-like & TLR1/2 & CCL3 & 70 & 78 & $\begin{array}{l}\text { TTCTGGTTACCCAAAAGTCTCGTCATATCT } \\
\text { GTGTGGATCCAAATCTCTCCTGGGTTGAG } \\
\text { GACATCATGAAAATGGTGGATGAACGCTC } \\
\text { CTTGTAAAGC }\end{array}$ \\
\hline $\begin{array}{l}\text { C-C motif } \\
\text { chemokine 4-like }\end{array}$ & TLR1/2 & CCL4 & 83 & 79 & $\begin{array}{l}\text { GCAATGGAATTGGTCCTGATGACTGCTGC } \\
\text { TTCAAATTCTACCCAAGAAGATTGAACAA } \\
\text { AAACCTCATCACTTCATATTACATGACTG } \\
\text { ATTACCGGTGCCC }\end{array}$ \\
\hline $\begin{array}{l}\text { monocyte } \\
\text { chemotactic 1B-like }\end{array}$ & TLR1/2 & CCL5 & 82 & 85 & $\begin{array}{l}\text { ATCATAATTTCGGACATGGCGTGTGCCGA } \\
\text { TCCAGAATTGGACGTGGCGAAGATTCCTC } \\
\text { TGATTGCGCTGAATGTGAGCGTGCGGAAA } \\
\text { AAGTTGGGGCTGT }\end{array}$ \\
\hline $\begin{array}{l}\text { chemokine CCL- } \\
\text { CUa precursor }\end{array}$ & RNASeq & $\begin{array}{l}\text { CCL- } \\
\text { CUa }\end{array}$ & 86 & 85 & $\begin{array}{l}\text { AGGCTGGACCAGCTGAGAAGTTGGCAGA } \\
\text { ATGCTGCAAATCAGTCAACAAACAGGAG } \\
\text { ATAACCGAACCAATCATAGGATACTTGAT } \\
\text { CCAGAAACGTGCGCC }\end{array}$ \\
\hline $\begin{array}{l}\text { B-cell receptor } \\
\text { CD22-like }\end{array}$ & Addition & $\mathrm{CD} 22$ & 82 & 86 & $\begin{array}{l}\text { AGGAGACATTTTCAAAGGAAGTTCGATGA } \\
\text { CTCTCACCTGCAGCAGTGATGCAAACCCA } \\
\text { CCTGTGACACAAAGCGGATACAGCCTGTA } \\
\text { TAAAGACGGACAC }\end{array}$ \\
\hline $\begin{array}{l}\text { inhibitor of nuclear } \\
\text { factor kappa-B } \\
\text { kinase subunit alpha }\end{array}$ & TLR1/2 & CHUK & 80 & 79 & $\begin{array}{l}\text { CCTGGCACCTGAGCTTTTTGAGAATAAGC } \\
\text { CATACACAGTTACTGTGGATTACTGGAGC } \\
\text { TTTGGCACGATGGTATTTGAATGCAGTTG } \\
\text { TGGTTTCCGTCCA }\end{array}$ \\
\hline $\begin{array}{l}\text { cytokine-inducible } \\
\text { SH2-containing } \\
\text { protein }\end{array}$ & Addition & $\mathrm{CISH}$ & 85 & 86 & $\begin{array}{l}\text { ACTTCTGCTATCTAGAAAATTCAGGATGG } \\
\text { TACTGGGGAGCTGTAACTGCGGCTCAGGC } \\
\text { CCATGCTGCACTTCAAGAGGCATCTGAAG } \\
\text { GAGCTTTTCTGGT }\end{array}$ \\
\hline $\begin{array}{l}\text { C-X-C motif } \\
\text { chemokine 11-like }\end{array}$ & TLR1/2 & $\begin{array}{l}\text { CXCL1 } \\
1\end{array}$ & 78 & 85 & $\begin{array}{l}\text { CTCTCATCACTGATGTCAAGGAGATTGAT } \\
\text { CCTCTTCCATATTGCAACAAGAAAGAAGT } \\
\text { CATTGTCACACTGAGAGATAACAGCCAAA } \\
\text { GGTGTCTTGACCC }\end{array}$ \\
\hline
\end{tabular}




\begin{tabular}{|c|c|c|c|c|c|}
\hline Transcript Name & $\begin{array}{l}\text { Classification } \\
\text { /Association }\end{array}$ & $\begin{array}{l}\text { HUGO } \\
\text { Gene } \\
\text { Abbrev } \\
\text { iation }\end{array}$ & $\begin{array}{l}\text { Tm } \\
\text { CP }\end{array}$ & $\begin{array}{l}\text { Tm } \\
\text { RP }\end{array}$ & Primer \\
\hline Interleukin 8 & TLR1/2 & CXCL8 & 85 & 86 & $\begin{array}{l}\text { ACATGAAGAGCAGCAAAGTCATTGTCACC } \\
\text { TCTATCGTGGTGCTCCTGGCCTTCCTGGCC } \\
\text { ATCAGTGAAGGGATGAGTTTGAGGAGCCT } \\
\text { GGGTGTAGAGCT }\end{array}$ \\
\hline Elongation Factor 1A & Housekeeper & EF1A & 85 & 85 & $\begin{array}{l}\text { AGATCAACGCAGGTTACGCACCTGTGCTG } \\
\text { GATTGCCACACAGCTCACATTGCCTGCAA } \\
\text { GTTCAAGGAGCTCATCGAGAAGATCGACC } \\
\text { GTCGTTCTGGCAA }\end{array}$ \\
\hline $\begin{array}{l}\text { Eukaryotic } \\
\text { Translation Initiation } \\
\text { Factor 3D }\end{array}$ & Housekeeper & EIF3D & 85 & 84 & $\begin{array}{l}\text { ACATGACTCAGTTCAACATGCAGACGCTA } \\
\text { CCTAAGAGCGCCAAGCAAAAGGAGAGGG } \\
\text { ATCGTATGCGCCTGCAGAAGAAGTTCCAA } \\
\text { AAGCAGTTTGGTGT }\end{array}$ \\
\hline Interferon gamma & PGN & IFNG & 83 & 81 & $\begin{array}{l}\text { CTTCACCAGGGAACCACTGACTGACAAAA } \\
\text { TTGAGGCAAAGATGGTGTTTATGGGTGGC } \\
\text { GTTTTGGACACGTATGAAAAGCTGATTAG } \\
\text { CCACATGTTGAAG }\end{array}$ \\
\hline BCR IgM mu & Addition & IGHM & 82 & 84 & $\begin{array}{l}\text { CTGCAGGGGAAGTGGATTTGATTTCAGTC } \\
\text { AGTATGGAATGCACTGGATCAGACAGCCT } \\
\text { TCAGGAAAAGCACTGGAATGGATGGGGC } \\
\text { TTATTTACTATGAT }\end{array}$ \\
\hline $\begin{array}{l}\text { inhibitor of nuclear } \\
\text { factor kappa-B } \\
\text { kinase subunit beta }\end{array}$ & TLR1/2 & IKBKB & 82 & 84 & $\begin{array}{l}\text { TGGGCGACGGACAGACTTGCCTCTGGTCT } \\
\text { TCCTGTTTGATCGTTCTTCCTGCACTTATG } \\
\text { AACCTCAGTTTGCTCCTCGCACCCTTCCAG } \\
\text { AGAACATCCGC }\end{array}$ \\
\hline $\begin{array}{l}\text { NF-kappa-B essential } \\
\text { modulator }\end{array}$ & TLR1/2 & IKBKG & 85 & 82 & $\begin{array}{l}\text { CAGACCAGCAATATTACTGAGGAGACTGT } \\
\text { TCAACATCGCTCTGAAGCACAGCACTCTT } \\
\text { CTGACTGGTATCGTGACTTGGAGGAGAAG } \\
\text { CTTGATTACCTTC }\end{array}$ \\
\hline Interleukin 10 & MCLR & IL10 & 85 & 85 & $\begin{array}{l}\text { TGGAGAGTAAAGGTCTATATAAGGCCATG } \\
\text { GGTGAGCTGGACCTGCTGTTTAACTACAT } \\
\text { TGAGACATATCTGGCTTCAAACCGGCACA } \\
\text { GAAAACCCAGAGC }\end{array}$ \\
\hline Interleukin $12 \mathrm{a}$ & TLR1/2 & IL12A & 81 & 82 & $\begin{array}{l}\text { GGAATTCATCCTTTAGTGAGAGTGAATGT } \\
\text { CTGAGGAACATCATGAAGGACTTGACCCA } \\
\text { CTACACCGCTGTTATTCAGTCTTACCGCAG } \\
\text { CTCCACACTCAT }\end{array}$ \\
\hline IL1b & $\begin{array}{l}\text { TLR } 1 / 2 \text { and } \\
\text { MCLR }\end{array}$ & IL1B & 83 & 81 & $\begin{array}{l}\text { ATCGTCGCCATAGAGAGGTTTAAGGGCAG } \\
\text { CAGATGCATTGACTCTGAAAACCTGCTCA } \\
\text { ACTTCATGCTGGAGAGCTTAGTGGAAGAG } \\
\text { CATATAGTGTTTG }\end{array}$ \\
\hline Interleukin-6 & TLR1/2 & IL6 & 81 & 84 & $\begin{array}{l}\text { GAATTCAGAGACGTGCAATATCTCTTTCT } \\
\text { GGACAACTACAAACCCTCCTCACTTCCAG } \\
\text { AAAACTGTCCTAAATCCAACTTCAGCAAG } \\
\text { GAGGCATGTCTCC }\end{array}$ \\
\hline
\end{tabular}




\begin{tabular}{|c|c|c|c|c|c|}
\hline Transcript Name & $\begin{array}{l}\text { Classification } \\
\text { /Association }\end{array}$ & $\begin{array}{l}\text { HUGO } \\
\text { Gene } \\
\text { Abbrev } \\
\text { iation }\end{array}$ & $\begin{array}{l}\mathbf{T m} \\
\mathbf{C P}\end{array}$ & $\begin{array}{l}\text { Tm } \\
\text { RP }\end{array}$ & Primer \\
\hline $\begin{array}{l}\text { interleukin-1 } \\
\text { receptor-associated } \\
\text { kinase } 1\end{array}$ & TLR1/2 & IRAK1 & 83 & 85 & $\begin{array}{l}\text { CCTCCTCTTCCTCCTCCTCGTTCGCTGGTC } \\
\text { CGTGTGAAACCGATGAGAGTCGAGGTTTC } \\
\text { TCCCAGTATGACCCTCGCGCCCAAGTCAG } \\
\text { ATCTAACGGGAC }\end{array}$ \\
\hline $\begin{array}{l}\text { interleukin-1 } \\
\text { receptor-associated } \\
\text { kinase } 4\end{array}$ & TLR1/2 & IRAK4 & 80 & 84 & $\begin{array}{l}\text { ACATGAGAACTTGGTTGACATGGTTGGAT } \\
\text { TTTGTTGTGATGGACAGCACCCATGTTTG } \\
\text { GTGTATGCCTTTATGGCCGCAGGTGACAC } \\
\text { CTCAGGTGAGGAG }\end{array}$ \\
\hline $\begin{array}{l}\text { interferon regulatory } \\
\text { factor } 5\end{array}$ & TLR1/2 & IRF5 & 85 & 85 & $\begin{array}{l}\text { GGGAGGACTGGCCCGACAAGAAACCCAA } \\
\text { AGAGAAAAAACTCATCATCGTGCAGGTGG } \\
\text { TTCCTGTGGTGGCTCGAATCCTGACGGAG } \\
\text { ATGTTCTCTGGAGA }\end{array}$ \\
\hline $\begin{array}{l}\text { c-Jun N-terminal } \\
\text { kinase } 1\end{array}$ & TLR1/2 & JNK & 83 & 84 & $\begin{array}{l}\text { TCATCTTCCAGGGCACCGACCACATTGAC } \\
\text { CAATGGAATAAGGTAATTGAGGTTCTGGG } \\
\text { CACGCCCAGTCTTGAGTTTATGAACCGAC } \\
\text { TGATGGAAACCGT }\end{array}$ \\
\hline $\begin{array}{l}\text { transcription factor } \\
\text { AP-1 }\end{array}$ & TLR1/2 & JUN & 83 & 84 & $\begin{array}{l}\text { ACCGTTTACAACAACAACGCCACCATGCG } \\
\text { CTCCGACTCGCCGGTTTATGAGGACTTGA } \\
\text { ACACTTTCAACCCAGCCATCAGCACCGTC } \\
\text { TCGGCTCCTAATT }\end{array}$ \\
\hline lymphotoxin alpha & Addition & LTA & 83 & 85 & $\begin{array}{l}\text { AGAACTTACCCAAATGTCACTCCTGCTCC } \\
\text { CTTGTCCTACATAACAACTCTATCCACTGC } \\
\text { AAGGAGAACAGCTTCTACTTCATCTACGC } \\
\text { CCAGGTCAACTT }\end{array}$ \\
\hline $\begin{array}{l}\text { dual specificity } \\
\text { mitogen-activated } \\
\text { protein kinase kinase } \\
2\end{array}$ & TLR1/2 & $\begin{array}{l}\text { MAP2K } \\
2\end{array}$ & 81 & 82 & $\begin{array}{l}\text { TCTTGAAATTAAACCTGCTATCAGAAACC } \\
\text { AGATCATCCGAGAGCTTCAGGTGCTGCAT } \\
\text { GAGTGTAACTCTCCCTACATTGTGGGCTTC } \\
\text { TATGGAGCATTT }\end{array}$ \\
\hline $\begin{array}{l}\text { dual specificity } \\
\text { mitogen-activated } \\
\text { kinase kinase } 4\end{array}$ & TLR1/2 & $\begin{array}{l}\text { MAP2K } \\
4\end{array}$ & 83 & 84 & $\begin{array}{l}\text { AGAATGGCTCCTAAAAAGAGACCAGTTCA } \\
\text { TTTAACCATTGGGCCTACTGGCGATGGGA } \\
\text { TGTCTACCTCCACCAACACTGATGTTACAT } \\
\text { CTGAGGCCAATT }\end{array}$ \\
\hline $\begin{array}{l}\text { dual specificity } \\
\text { mitogen-activated } \\
\text { protein kinase kinase } \\
6\end{array}$ & TLR1/2 & $\begin{array}{l}\text { MAP2K } \\
6 \\
\end{array}$ & 82 & 84 & $\begin{array}{l}\text { ACATCTTGGGCAAGATCACAGTAGCGATT } \\
\text { GTCAAGGCATTAGAGCATCTGCACAGTAA } \\
\text { CCTGTCAGTGATACACAGAGATGTGAAGC } \\
\text { CCTCCAATGTTCT }\end{array}$ \\
\hline $\begin{array}{l}\text { P38 mitogen- } \\
\text { activated protein } \\
\text { kinase kinase kinase } \\
13\end{array}$ & TLR1/2 & $\begin{array}{l}\text { MAP3K } \\
13\end{array}$ & 83 & 84 & $\begin{array}{l}\text { GTTGTGTTGTGGGAACTTCTGACCGGAGA } \\
\text { GATTCCCTACAAAGACGTAGACTCCTCGG } \\
\text { CCATCATTTGGGGTGTTGGCAGCAACAGT } \\
\text { CTCCACCTTCCTG }\end{array}$ \\
\hline $\begin{array}{l}\text { mitogen activated } \\
\text { protein kinase kinase } \\
\text { kinase } 7\end{array}$ & TLR1/2 & $\begin{array}{l}\text { MAP3K } \\
7\end{array}$ & 91 & 92 & $\begin{array}{l}\text { CCTGCTGATCCAGAGAAAGAAGGAGCTCA } \\
\text { TCGCTGAACTGGACCAAGATGAGAAGGA } \\
\text { CCAGCAGAACACGTCCCGTCTGGTGCAGG } \\
\text { AGCACAAAAAGCTC }\end{array}$ \\
\hline
\end{tabular}




\begin{tabular}{|c|c|c|c|c|c|}
\hline Transcript Name & $\begin{array}{l}\text { Classification } \\
\text { /Association }\end{array}$ & $\begin{array}{l}\text { HUGO } \\
\text { Gene } \\
\text { Abbrev } \\
\text { iation }\end{array}$ & $\begin{array}{l}\mathbf{T m} \\
\mathbf{C P}\end{array}$ & $\begin{array}{l}\text { Tm } \\
\text { RP }\end{array}$ & Primer \\
\hline $\begin{array}{l}\text { mitogen-activated } \\
\text { protein kinase kinase } \\
\text { kinase 8-like }\end{array}$ & TLR1/2 & $\begin{array}{l}\text { MAP3K } \\
8\end{array}$ & 86 & 85 & $\begin{array}{l}\text { CAAACCCAGTAACATTGTCCTGATGTCAG } \\
\text { ACAAGGCAGTGCTGGTGGACTTTGGCCTG } \\
\text { ACAGTTCAGATGACAGAGGACATATACAT } \\
\text { TCCTAGAGACCTG }\end{array}$ \\
\hline $\begin{array}{l}\text { mitogen-activated } \\
\text { kinase } 1\end{array}$ & TLR1/2 & MAPK1 & 84 & 84 & $\begin{array}{l}\text { TCAGTGGGTTGCATCCTGGCTGAGATGTT } \\
\text { GTCCAACAGGCCAATCTTTCCTGGGAAGC } \\
\text { ACTACTTGGATCAGCTTAACCACATTTTG } \\
\text { GGGATCCTGGGTT }\end{array}$ \\
\hline $\begin{array}{l}\text { myeloid } \\
\text { differentiation factor } \\
88\end{array}$ & TLR1/2 & MYD88 & 85 & 85 & $\begin{array}{l}\text { CTGGAGGAGGTGGAGAGAAAAGACATTG } \\
\text { TGGAGGATCTTCGTCCCTTAATAGATGAG } \\
\text { GATGTCAGGAAGTATTGTGAAAGTCTGAA } \\
\text { GAAGAAGGCTGAAC }\end{array}$ \\
\hline $\begin{array}{l}\text { neutrophil cytosol } \\
\text { factor } 1\end{array}$ & Addition & NCF1 & 85 & 81 & $\begin{array}{l}\text { CACACCGGAGACCTGGTGGAAATTGTAGA } \\
\text { GAAAAGTCAGAACGGTTGGTGGTTCTGCC } \\
\text { AGTATGAGAATAAACACGGCTGGGTTCCT } \\
\text { GCATCCTATTTGG }\end{array}$ \\
\hline $\begin{array}{l}\text { nuclear factor NF- } \\
\text { kappa-B p105 }\end{array}$ & TLR1/2 & NFKB1 & 85 & 85 & $\begin{array}{l}\text { AAGCAGGAAGTGTGTCGTGCTCTGGAGAG } \\
\text { TGAAGGATGCTGGGAGAATCTGGCTCACG } \\
\text { GTCTGGGTCTCGGGATCCTCAACACGGCC } \\
\text { TTCAGACTGAGCC }\end{array}$ \\
\hline $\begin{array}{l}\text { nuclear factor NF- } \\
\text { kappa-B p100 } \\
\text { subunit }\end{array}$ & Addition & NFKB2 & 85 & 86 & $\begin{array}{l}\text { ACGCCTCCAACCTGAAAATCTCTCGGATG } \\
\text { GACAAAACGTGCGGCTCGGTGCTCGGGGG } \\
\text { AGACGAGATCTTCCTGCTCTGTGACAAAG } \\
\text { TCCAGAAAGACGA }\end{array}$ \\
\hline $\begin{array}{l}\text { NF-kappa-B inhibitor } \\
\text { alpha }\end{array}$ & TLR1/2 & $\begin{array}{l}\text { NFKBI } \\
\text { A }\end{array}$ & 85 & 86 & $\begin{array}{l}\text { ACACGCCTCTTCACATCGCCTGTCGCCAT } \\
\text { GGTAACCTGCTGTGCTTCAGCGTCATCAC } \\
\text { GCAGAACTGTCAGCCGGAGTATCTACACA } \\
\text { GGGTGATGGCTGC }\end{array}$ \\
\hline $\begin{array}{l}\text { phosphoinositide 3- } \\
\text { kinase regulatory } \\
\text { subunit } 5\end{array}$ & TLR1/2 & PIK3R5 & 80 & 83 & $\begin{array}{l}\text { GCTCCATCCCTCTTCTCTGTCACTTCTGGA } \\
\text { GCTGACAGTGACTATTTTGAAGATTCTGA } \\
\text { TGAGAACATCTGCTCCTCTCCCGTTGCCG } \\
\text { AAAAATGCTCGC }\end{array}$ \\
\hline cyclooxygenase 2 & Addition & PTGS2 & 82 & 79 & $\begin{array}{l}\text { AAGACAATTCATTCCGGACCCGCAGGGCA } \\
\text { CCAGTCTGATGTTTGCATTCTTCGCGCAGC } \\
\text { ATTTCACCCACCAGTTCTTTAAATCCGATA } \\
\text { TGAAGAAAGGG }\end{array}$ \\
\hline $\begin{array}{l}\text { ras-related } \mathrm{C} 3 \\
\text { botulinum toxin } \\
\text { substrate } 1\end{array}$ & TLR1/2 & RAC1 & 79 & 83 & $\begin{array}{l}\text { TACCCACAGACGGATGTGTTTCTCATCTG } \\
\text { CTTTTCGCTTGTGAGTCCCGCCTCGTTTGA } \\
\text { AAACGTCCGTGCCAAGTGGTACCCTGAGG } \\
\text { TGAGACACCATT }\end{array}$ \\
\hline $\begin{array}{l}\text { transcription factor } \\
\text { p65 }\end{array}$ & TLR1/2 & RELA & 86 & 85 & $\begin{array}{l}\text { GACGTCCATAGGCAGGTGGCCATTGTGTT } \\
\text { CCGCACACCGCCGTACCGTGACACTAACC } \\
\text { TCTCTGAGCCTATTAGAGTGAAAATGCAG } \\
\text { CTCCGCCGGCCCT }\end{array}$ \\
\hline
\end{tabular}




\begin{tabular}{|c|c|c|c|c|c|}
\hline Transcript Name & $\begin{array}{l}\text { Classification } \\
\text { /Association }\end{array}$ & $\begin{array}{l}\text { HUGO } \\
\text { Gene } \\
\text { Abbrev } \\
\text { iation } \\
\end{array}$ & $\begin{array}{l}\text { Tm } \\
\mathbf{C P}\end{array}$ & $\begin{array}{l}\mathbf{T m} \\
\mathbf{R P}\end{array}$ & Primer \\
\hline $\begin{array}{l}\text { Ribosomal Protein } \\
\text { L8 }\end{array}$ & Housekeeper & RPL18 & 85 & 85 & $\begin{array}{l}\text { TTCTCCTCTGCAAACAGAGCTGTTGTTGGT } \\
\text { GTGGTAGCTGGAGGTGGTCGTATTGACAA } \\
\text { GCCCATCCTGAAGGCTGGTCGTGCCTACC } \\
\text { ATAAGTACAAGG }\end{array}$ \\
\hline $\begin{array}{l}\text { 40S ribosomal } \\
\text { protein } \mathrm{S} 12\end{array}$ & Housekeeper & RPS12 & 86 & 85 & $\begin{array}{l}\text { CTCCCTGATCCACGATGGCCTTGCCCGTG } \\
\text { GTATCCGTGAGGCCACAAAGGCCCTGGAC } \\
\text { AAGCGTCAGGCTCATCTCTGCGCTCTGGC } \\
\text { TGCCAACTGCGAT }\end{array}$ \\
\hline $\begin{array}{l}\text { natural resistance- } \\
\text { associated } \\
\text { macrophage } 2\end{array}$ & Addition & $\begin{array}{l}\text { SLC11 } \\
\text { A1 }\end{array}$ & 85 & 85 & $\begin{array}{l}\text { GGGTAAGCTATCCACCTGCTGTGTTCATA } \\
\text { GAGGACGCCGTCTGAGTACGACTCCTAGA } \\
\text { GCTGAACAGGAGCACTAACCACCAGCATT } \\
\text { CCTCTTTCCTCTT }\end{array}$ \\
\hline $\begin{array}{l}\text { suppressor of } \\
\text { cytokine signalling } 1\end{array}$ & Addition & SOCS1 & 87 & 92 & $\begin{array}{l}\text { GTATCTGACCCACTTCCCCACCTTCTCCTG } \\
\text { CAAGGAGGACTGTGTGATCATCACAGACA } \\
\text { CAGCGTCCAAGCTCGAGCGCAGCTCCTTC } \\
\text { TACTGGGGCCCT }\end{array}$ \\
\hline $\begin{array}{l}\text { suppressor of } \\
\text { cytokine signalling } 2\end{array}$ & Addition & SOCS2 & 85 & 86 & $\begin{array}{l}\text { CCACCAACCTGCGGATCGAGTACAAACAC } \\
\text { GGCAAATTCAAGCTGGACTCGGTGGTTCT } \\
\text { GGTGAAGCCCAAGCTGAAGCAGTTCGACA } \\
\text { GCGTGGTCCACCT }\end{array}$ \\
\hline $\begin{array}{l}\text { suppressor of } \\
\text { cytokine signalling } 3\end{array}$ & MCLR & SOCS3 & 82 & 85 & $\begin{array}{l}\text { CCCACTTTGACTGTGTCCTCAAGCTGGTCC } \\
\text { ATTACTACATGTCTCAGAACAAAGGGAAC } \\
\text { ACTCGCAGTGGGAATATCTACTACATTTA } \\
\text { CTCTGGCGGGGA }\end{array}$ \\
\hline $\begin{array}{l}\text { suppressor of } \\
\text { cytokine signalling } 4\end{array}$ & MCLR & SOCS4 & 84 & 85 & $\begin{array}{l}\text { TGGCCACACTGACTACATCTTGGTCCCAG } \\
\text { ATCTCCTCCAGATCAACAACAGCTCTTGTT } \\
\text { ACTGGGGTGTGCTTAACCGCTTTGAGGCA } \\
\text { GAGGAGCTACTG }\end{array}$ \\
\hline $\begin{array}{l}\text { suppressor of } \\
\text { cytokine signalling } 5\end{array}$ & Addition & SOCS5 & 86 & 84 & $\begin{array}{l}\text { GTGGGAACCGTAGGGACAGACGTTATGG } \\
\text { AGTGTGCTCCATCCAGGACATGAGCGACT } \\
\text { CTGTATCTGGAGGACGCAGTCTGAATGCT } \\
\text { CGGTCTTTGCGCCA }\end{array}$ \\
\hline $\begin{array}{l}\text { suppressor of } \\
\text { cytokine signalling } 6\end{array}$ & Addition & SOCS6 & 82 & 84 & $\begin{array}{l}\text { CGGAAAGAATTTCACGATTTCCAGATGGA } \\
\text { AGGGCTCTTTCAGGACCAAGCAGAATCCT } \\
\text { TAAAGAATCTCCAGCAGCCTCAAAACGGT } \\
\text { GAGCTGCATCTAA }\end{array}$ \\
\hline $\begin{array}{l}\text { suppressor of } \\
\text { cytokine signalling } 7\end{array}$ & Addition & SOCS7 & 83 & 82 & $\begin{array}{l}\text { CACTACAGAGGTACGTTCAGCCTCTGGTG } \\
\text { TCACCCTAAGTTTGAGGATCGCTGTCACT } \\
\text { CTGTGGTGGAGTTCATTGAACGAGCTATC } \\
\text { ATGCACTCCAAGA }\end{array}$ \\
\hline $\begin{array}{l}\text { TGF-beta-activated } \\
\text { kinase } 1 \text { and } \\
\text { MAP3K7-binding 1 }\end{array}$ & TLR1/2 & TAB1 & 92 & 89 & $\begin{array}{l}\text { GCTAGCTGACGGAGCGGTCACGCCCACAC } \\
\text { AGGGTGGACGTATCTACCCTGTATCAGTG } \\
\text { CCCTACTCCAACAGCCAGAGCACTAGTAA } \\
\text { AACCAGTGTCACC }\end{array}$ \\
\hline
\end{tabular}




\begin{tabular}{|c|c|c|c|c|c|}
\hline Transcript Name & $\begin{array}{l}\text { Classification } \\
\text { /Association }\end{array}$ & $\begin{array}{l}\text { HUGO } \\
\text { Gene } \\
\text { Abbrev } \\
\text { iation }\end{array}$ & $\begin{array}{l}\mathbf{T m} \\
\mathbf{C P}\end{array}$ & $\begin{array}{l}\text { Tm } \\
\text { RP }\end{array}$ & Primer \\
\hline $\begin{array}{l}\text { TGF-beta-activated } \\
\text { kinase } 1 \text { and } \\
\text { MAP3K7-binding } 2\end{array}$ & TLR1/2 & TAB2 & 79 & 86 & $\begin{array}{l}\text { TCCTCTGGTGTCTCCTCGTGCTCTTCTTCC } \\
\text { TCTTCCTCCTCCTCTGTCATGCCCACATCC } \\
\text { CTGTCTACCATCAGCCAGTACAACATCCA } \\
\text { GAACATCTCCA }\end{array}$ \\
\hline TGFB1 & MCLR & TGFB & 83 & 84 & $\begin{array}{l}\text { AATAACACAGAGAACACCAAGACCTCCA } \\
\text { AAAGCATCCCGATGTTCTTCAGCATCTCT } \\
\text { AACATACGGGAAAGTGTGGGGGATTCCA } \\
\text { GTTTGCTGACCAGTG }\end{array}$ \\
\hline $\begin{array}{l}\text { toll interleukin-1 } \\
\text { receptor domain- } \\
\text { containing adapter }\end{array}$ & TLR $1 / 2$ & TIRAP & 83 & 85 & $\begin{array}{l}\text { CGCTGTTGCGATGGAGCCGAAAGTATGAC } \\
\text { GTGTTTGTGTGCCACAGCTCTGTGGACAG } \\
\text { CGACATTGAAGAGGCTGGACGCCTGGTTT } \\
\text { CTTTCCTGGAGGC }\end{array}$ \\
\hline Toll-like receptor 1 & TLR1/2 & TLR1 & 79 & 82 & $\begin{array}{l}\text { ACTCACTTTGTAAACGTGGTTCTGTGTACA } \\
\text { TCTCTTACCAGTCTGAGCGCCTCTGATGTG } \\
\text { GCCCTCAACAAGTTGCCTTATATAGACAC } \\
\text { TAATGTGACCA }\end{array}$ \\
\hline Toll-like receptor 2 & TLR1/2 & TLR2 & 83 & 84 & $\begin{array}{l}\text { ACCCTGACTTTATGAATAAACTACTCAAG } \\
\text { GTGATCTGCACGTCCAACCAGCAGCTTCA } \\
\text { AGGGTCCACTGTGATGCCCTTCCAGCCTC } \\
\text { CGTCTATATACAA }\end{array}$ \\
\hline $\begin{array}{l}\text { tumor necrosis } \\
\text { factor-alpha }\end{array}$ & $\begin{array}{l}\text { TLR } 1 / 2 \text { and } \\
\text { MCLR }\end{array}$ & TNF & 82 & 85 & $\begin{array}{l}\text { TCAGGGAGGTTTCCAACTAGTGAAGAACC } \\
\text { AGATTGTTATCCCACAAACTGGCCTCTAC } \\
\text { TTCGTCTACAGCCAGGCATCGTTCAGAGT } \\
\text { CTCCTGCAGCAAT }\end{array}$ \\
\hline $\begin{array}{l}\text { toll-interacting } \\
\text { isoform } 2\end{array}$ & TLR1/2 & $\begin{array}{l}\text { TOLLI } \\
\mathrm{P}\end{array}$ & 83 & 84 & $\begin{array}{l}\text { GTTGAAGTGGAGTTGATGAATTTGACTGG } \\
\text { AGGCTACAAAGACCTAAGTGAGCAGTTGA } \\
\text { GAGAGAGAGCCAAAATCCACACATCTCAT } \\
\text { CTTGATCTCAGCA }\end{array}$ \\
\hline $\begin{array}{l}\text { tumor necrosis factor } \\
\text { receptor type 1- } \\
\text { associated DEATH } \\
\text { domain }\end{array}$ & TLR1/2 & $\begin{array}{l}\text { TRAD } \\
\mathrm{D}\end{array}$ & 92 & 93 & $\begin{array}{l}\text { GCTGTCGGGCTCTGAAGGGTCCGGCTATA } \\
\text { GACAACCTGGCCTACGAGTACGAGAGAG } \\
\text { AAGGGCTCTATGAGCAAGCCTACCAGCTG } \\
\text { CTCAGCCGCTTCAT }\end{array}$ \\
\hline $\begin{array}{l}\text { TNF Receptor } \\
\text { Associated Factor } 6\end{array}$ & TLR1/2 & TRAF6 & 83 & 85 & $\begin{array}{l}\text { CCGCGCTGCTCCAACTATATCTCCCTCTTT } \\
\text { GTTCACACCATGCAAGGAGTTTTTGATGG } \\
\text { GCAGCTGACATGGCCCTTCCAGGGCACCA } \\
\text { TTCGCCTTGCCA }\end{array}$ \\
\hline
\end{tabular}


Table 4. Median, maximum, and minimum transcript abundance counts for specific genes of interest in the liver at each time point $(6,12$, and $24 \mathrm{hr}$.) during the first hepatocyte challenge on Jan-16-2018. Data below the detection limit are reported as BD.

\begin{tabular}{|c|c|c|c|c|c|c|c|c|c|c|c|c|}
\hline & \multicolumn{12}{|c|}{6 Hour } \\
\hline & \multicolumn{3}{|c|}{ Control } & \multicolumn{3}{|c|}{ Low } & \multicolumn{3}{|c|}{ Medium } & \multicolumn{3}{|c|}{ High } \\
\hline & Median & Max & Min & Median & Max & Min & Median & Max & Min & Median & Max & Min \\
\hline CAT & 315 & 481 & 258 & 389 & 545 & 277 & 402 & 528 & 296 & 386 & 449 & 340 \\
\hline CYP1A & 220 & 343 & 106 & 275 & 473 & 143 & 266 & 442 & 163 & 281 & 429 & 129 \\
\hline CYP3A & 622 & 941 & 540 & 766 & 1306 & 619 & 741 & 1266 & 664 & 723 & 1258 & 657 \\
\hline GSTrho & $\mathrm{BD}$ & 8 & $\mathrm{BD}$ & $\mathrm{BD}$ & $\mathrm{BD}$ & $\mathrm{BD}$ & $\mathrm{BD}$ & 4 & $\mathrm{BD}$ & $\mathrm{BD}$ & BD & $\mathrm{BD}$ \\
\hline GLK & 3 & 50 & $\mathrm{BD}$ & $\mathrm{BD}$ & 33 & $\mathrm{BD}$ & $\mathrm{BD}$ & 38 & $\mathrm{BD}$ & $\mathrm{BD}$ & 30 & $\mathrm{BD}$ \\
\hline GPX & 4 & 25 & BD & $\mathrm{BD}$ & 6 & BD & 2 & 8 & BD & BD & 33 & $\mathrm{BD}$ \\
\hline GSR & 2 & 33 & BD & BD & 4 & BD & $\mathrm{BD}$ & 10 & $\mathrm{BD}$ & $\mathrm{BD}$ & $\mathrm{BD}$ & $\mathrm{BD}$ \\
\hline GSTtheta & 619 & 1040 & 366 & 726 & 1025 & 459 & 622 & 983 & 335 & 668 & 1178 & 415 \\
\hline HSP71 & 2329 & 2774 & 1155 & 2649 & 4168 & 2193 & 2840 & 4316 & 2363 & 2775 & 3897 & 2271 \\
\hline HSP90B & 1226 & 1637 & 875 & 1437 & 2151 & 1239 & 1427 & 2023 & 1258 & 1427 & 1969 & 1163 \\
\hline IL1b & BD & 48 & $\mathrm{BD}$ & $\mathrm{BD}$ & $\mathrm{BD}$ & $\mathrm{BD}$ & BD & BD & BD & $\mathrm{BD}$ & 23 & $\mathrm{BD}$ \\
\hline PCNA & BD & 5 & $\mathrm{BD}$ & $\mathrm{BD}$ & $\mathrm{BD}$ & BD & $\mathrm{BD}$ & BD & $\mathrm{BD}$ & BD & $\mathrm{BD}$ & $\mathrm{BD}$ \\
\hline SOD & 50 & 87 & BD & 51 & 80 & BD & 54 & 88 & $\mathrm{BD}$ & 41 & 73 & $\mathrm{BD}$ \\
\hline TGFB & $\mathrm{BD}$ & 23 & $\mathrm{BD}$ & $\mathrm{BD}$ & $\mathrm{BD}$ & $\mathrm{BD}$ & $\mathrm{BD}$ & $\mathrm{BD}$ & $\mathrm{BD}$ & $\mathrm{BD}$ & $\mathrm{BD}$ & $\mathrm{BD}$ \\
\hline
\end{tabular}

\begin{tabular}{|c|c|c|c|c|c|c|c|c|c|c|c|c|}
\hline & \multicolumn{12}{|c|}{12 Hour } \\
\hline & \multicolumn{3}{|c|}{ Control } & \multicolumn{3}{|c|}{ Low } & \multicolumn{3}{|c|}{ Medium } & \multicolumn{3}{|c|}{ High } \\
\hline & Median & Max & Min & Median & Max & Min & Median & Max & Min & Median & Max & Min \\
\hline CAT & 333 & 438 & 272 & 332 & 393 & 295 & 353 & 489 & 240 & 352 & 460 & 231 \\
\hline CYP1A & 206 & 398 & 99 & 212 & 387 & 147 & 218 & 450 & 102 & 233 & 395 & 155 \\
\hline CYP3A & 953 & 1486 & 807 & 1069 & 1596 & 876 & 1077 & 1466 & 919 & 1162 & 1310 & 936 \\
\hline GSTrho & $\mathrm{BD}$ & $\mathrm{BD}$ & $\mathrm{BD}$ & $\mathrm{BD}$ & $\mathrm{BD}$ & $\mathrm{BD}$ & $\mathrm{BD}$ & $\mathrm{BD}$ & $\mathrm{BD}$ & $\mathrm{BD}$ & 2 & $\mathrm{BD}$ \\
\hline GLK & 37 & 133 & $\mathrm{BD}$ & 53 & 135 & $\mathrm{BD}$ & 54 & 118 & $\mathrm{BD}$ & 29 & 128 & $\mathrm{BD}$ \\
\hline GPX & BD & 2 & BD & BD & 6 & BD & BD & 16 & BD & BD & 15 & $\mathrm{BD}$ \\
\hline GSR & 1 & 29 & BD & BD & 31 & BD & 7 & 28 & BD & BD & 46 & BD \\
\hline GSTtheta & 565 & 890 & 218 & 572 & 861 & 366 & 521 & 1139 & 361 & 487 & 864 & 270 \\
\hline HSP71 & 2863 & 4431 & 2255 & 2668 & 3908 & 2417 & 2521 & 4233 & 2033 & 2887 & 5708 & 2101 \\
\hline HSP90B & 1510 & 2021 & 1202 & 1477 & 1904 & 1319 & 1422 & 2432 & 1272 & 1473 & 2492 & 1250 \\
\hline IL1b & $\mathrm{BD}$ & $\mathrm{BD}$ & $\mathrm{BD}$ & $\mathrm{BD}$ & $\mathrm{BD}$ & $\mathrm{BD}$ & $\mathrm{BD}$ & $\mathrm{BD}$ & $\mathrm{BD}$ & $\mathrm{BD}$ & $\mathrm{BD}$ & $\mathrm{BD}$ \\
\hline PCNA & $\mathrm{BD}$ & BD & $\mathrm{BD}$ & $\mathrm{BD}$ & $\mathrm{BD}$ & $\mathrm{BD}$ & $\mathrm{BD}$ & $\mathrm{BD}$ & $\mathrm{BD}$ & $\mathrm{BD}$ & 12 & $\mathrm{BD}$ \\
\hline SOD & 45 & 79 & $\mathrm{BD}$ & 55 & 91 & $\mathrm{BD}$ & 59 & 94 & $\mathrm{BD}$ & 36 & 96 & $\mathrm{BD}$ \\
\hline TGFB & BD & BD & $\mathrm{BD}$ & BD & $\mathrm{BD}$ & $\mathrm{BD}$ & BD & BD & BD & BD & $\mathrm{BD}$ & $\mathrm{BD}$ \\
\hline
\end{tabular}




\begin{tabular}{|r|c|c|c|c|c|c|c|c|c|c|c|c|}
\hline & \multicolumn{10}{|c|}{ L4 Hour } \\
\hline & \multicolumn{3}{|c|}{ Control } & \multicolumn{3}{|c|}{ Low } & \multicolumn{3}{c|}{ Medium } & \multicolumn{3}{c|}{ High } \\
\hline & Median & Max & Min & Median & Max & Min & Median & Max & Min & Median & Max & Min \\
\hline CAT & 315 & 400 & 204 & 312 & 354 & 237 & 306 & 332 & 235 & 272 & 322 & 205 \\
\hline CYP1A & 105 & 157 & 1 & 118 & 147 & 37 & 105 & 203 & 50 & 93 & 129 & 38 \\
\hline CYP3A & 1389 & 1951 & 1229 & 1370 & 1656 & 1241 & 1465 & 1610 & 1122 & 1373 & 1698 & 1273 \\
\hline GSTrho & BD & BD & BD & BD & BD & BD & BD & BD & BD & BD & BD & BD \\
\hline GLK & 8 & 76 & BD & 7 & 93 & BD & 14 & 77 & BD & BD & 66 & BD \\
\hline GPX & BD & BD & BD & BD & BD & BD & BD & 15 & BD & BD & BD & BD \\
\hline GSR & BD & 29 & BD & BD & 32 & BD & BD & 36 & BD & BD & 35 & BD \\
\hline GSTtheta & 408 & 572 & 86 & 394 & 574 & 204 & 410 & 624 & 167 & 417 & 541 & 219 \\
\hline HSP71 & 3066 & 6264 & 2356 & 3221 & 4236 & 2964 & 2951 & 4524 & 2519 & 2927 & 3850 & 2240 \\
\hline HSP90B & 1619 & 2811 & 1364 & 1637 & 2062 & 1480 & 1542 & 2264 & 1425 & 1535 & 2178 & 1336 \\
\hline IL1b & BD & BD & BD & BD & BD & BD & BD & BD & BD & BD & BD & BD \\
\hline PCNA & BD & 19 & BD & BD & BD & BD & BD & 13 & BD & BD & 8 & BD \\
\hline SOD & 57 & 87 & BD & 48 & 82 & 10 & 56 & 116 & BD & 34 & 59 & BD \\
\hline TGFB & BD & BD & BD & BD & BD & BD & BD & BD & BD & BD & BD & BD \\
\hline
\end{tabular}


Table 5. Median, maximum, and minimum transcript abundance counts for specific genes of

interest in the liver at each time point $(6,12$, and $24 \mathrm{hr}$.) during the first hepatocyte challenge on

Feb-26-2018. Data below the detection limit of the assay are represented as BD.

\begin{tabular}{|c|c|c|c|c|c|c|c|c|c|c|c|c|c|c|c|}
\hline & \multicolumn{15}{|c|}{6 Hour } \\
\hline & \multicolumn{3}{|c|}{ Control } & \multicolumn{3}{|c|}{ Low } & \multicolumn{3}{|c|}{ Med } & \multicolumn{3}{|c|}{ High } & \multicolumn{3}{|c|}{ Severe } \\
\hline & Median & Max & Min & Median & Max & Min & Median & Max & Min & Median & Max & Min & Median & Max & Min \\
\hline CAT & 163 & 439 & 135 & 168 & 285 & 110 & 155 & 298 & 104 & 166 & 231 & 136 & 170 & 207 & 142 \\
\hline CYP1A & 121 & 446 & 53 & 131 & 390 & 92 & 115 & 421 & 82 & 120 & 431 & 95 & 94 & 323 & 61 \\
\hline CYP3A & 1324 & 1909 & 486 & 1204 & 1742 & 552 & 1197 & 1833 & 501 & 1127 & 1835 & 517 & 1231 & 1866 & 501 \\
\hline GSTrho & $\mathrm{BD}$ & $\mathrm{BD}$ & $\mathrm{BD}$ & $\mathrm{BD}$ & 9 & $\mathrm{BD}$ & $\mathrm{BD}$ & $\mathrm{BD}$ & $\mathrm{BD}$ & $\mathrm{BD}$ & 5 & $\mathrm{BD}$ & $\mathrm{BD}$ & $\mathrm{BD}$ & $\mathrm{BD}$ \\
\hline GLK & $\mathrm{BD}$ & $\mathrm{BD}$ & $\mathrm{BD}$ & $\mathrm{BD}$ & $\mathrm{BD}$ & $\mathrm{BD}$ & $\mathrm{BD}$ & $\mathrm{BD}$ & $\mathrm{BD}$ & $\mathrm{BD}$ & $\mathrm{BD}$ & $\mathrm{BD}$ & $\mathrm{BD}$ & $\mathrm{BD}$ & $\mathrm{BD}$ \\
\hline GPX & $\mathrm{BD}$ & 9 & $\mathrm{BD}$ & $\mathrm{BD}$ & 18 & $\mathrm{BD}$ & $\mathrm{BD}$ & 3 & $\mathrm{BD}$ & $\mathrm{BD}$ & 9 & $\mathrm{BD}$ & $\mathrm{BD}$ & $\mathrm{BD}$ & $\mathrm{BD}$ \\
\hline GSR & $\mathrm{BD}$ & $\mathrm{BD}$ & $\mathrm{BD}$ & $\mathrm{BD}$ & 9 & $\mathrm{BD}$ & $\mathrm{BD}$ & $\mathrm{BD}$ & $\mathrm{BD}$ & $\mathrm{BD}$ & 16 & $\mathrm{BD}$ & $\mathrm{BD}$ & 4 & $\mathrm{BD}$ \\
\hline GSTtheta & 502 & 1012 & 460 & 463 & 533 & 367 & 358 & 458 & 304 & 435 & 629 & 348 & 407 & 623 & 335 \\
\hline HSP71 & 1691 & 4497 & 1437 & 1753 & 2023 & 1404 & 1706 & 2441 & 1627 & 1953 & 2330 & 1552 & 1867 & 2614 & 1388 \\
\hline HSP90B & 1429 & 3441 & 1135 & 1258 & 1480 & 1102 & 1283 & 1500 & 1121 & 1333 & 1637 & 1095 & 1325 & 1480 & 1126 \\
\hline IL1b & $\mathrm{BD}$ & $\mathrm{BD}$ & $\mathrm{BD}$ & $\mathrm{BD}$ & $\mathrm{BD}$ & $\mathrm{BD}$ & $\mathrm{BD}$ & $\mathrm{BD}$ & $\mathrm{BD}$ & $\mathrm{BD}$ & $\mathrm{BD}$ & $\mathrm{BD}$ & $\mathrm{BD}$ & $\mathrm{BD}$ & $\mathrm{BD}$ \\
\hline PCNA & $\mathrm{BD}$ & $\mathrm{BD}$ & $\mathrm{BD}$ & $\mathrm{BD}$ & $\mathrm{BD}$ & $\mathrm{BD}$ & $\mathrm{BD}$ & $\mathrm{BD}$ & $\mathrm{BD}$ & $\mathrm{BD}$ & 7 & $\mathrm{BD}$ & $\mathrm{BD}$ & 4 & $\mathrm{BD}$ \\
\hline SOD & 9 & 24 & $\mathrm{BD}$ & 10 & 33 & $\mathrm{BD}$ & 7 & 45 & $\mathrm{BD}$ & 13 & 52 & $\mathrm{BD}$ & 3 & 32 & $\mathrm{BD}$ \\
\hline TGFB & $\mathrm{BD}$ & $\mathrm{BD}$ & $\mathrm{BD}$ & $\mathrm{BD}$ & $\mathrm{BD}$ & $\mathrm{BD}$ & $\mathrm{BD}$ & $\mathrm{BD}$ & $\mathrm{BD}$ & $\mathrm{BD}$ & $\mathrm{BD}$ & $\mathrm{BD}$ & $\mathrm{BD}$ & $\mathrm{BD}$ & $\mathrm{BD}$ \\
\hline
\end{tabular}

\begin{tabular}{|c|c|c|c|c|c|c|c|c|c|c|c|c|c|c|c|}
\hline & \multicolumn{15}{|c|}{12 Hour } \\
\hline & \multicolumn{3}{|c|}{ Control } & \multicolumn{3}{|c|}{ Low } & \multicolumn{3}{|c|}{ Med } & \multicolumn{3}{|c|}{ High } & \multicolumn{3}{|c|}{ Severe } \\
\hline & Median & $\operatorname{Max}$ & Min & Median & $\operatorname{Max}$ & Min & Median & $\operatorname{Max}$ & Min & Median & $\operatorname{Max}$ & Min & Median & $\operatorname{Max}$ & Min \\
\hline CAT & 141 & 237 & 105 & 138 & 248 & 118 & 140 & 275 & 101 & 126 & 260 & 95 & 118 & 231 & 92 \\
\hline CYP1A & 187 & 568 & 105 & 186 & 566 & 106 & 153 & 566 & 95 & 163 & 535 & 92 & 102 & 321 & 75 \\
\hline CYP3A & 2115 & 2936 & 764 & 2122 & 2950 & 791 & 2163 & 2850 & 868 & 2065 & 3136 & 794 & 1744 & 2641 & 796 \\
\hline GSTrho & $\mathrm{BD}$ & $\mathrm{BD}$ & $\mathrm{BD}$ & $\mathrm{BD}$ & 12 & $\mathrm{BD}$ & $\mathrm{BD}$ & 3 & $\mathrm{BD}$ & $\mathrm{BD}$ & 1 & $\mathrm{BD}$ & $\mathrm{BD}$ & 3 & $\mathrm{BD}$ \\
\hline GLK & 3 & 144 & $\mathrm{BD}$ & $\mathrm{BD}$ & 91 & $\mathrm{BD}$ & $\mathrm{BD}$ & 87 & $\mathrm{BD}$ & 5 & 78 & $\mathrm{BD}$ & $\mathrm{BD}$ & 46 & $\mathrm{BD}$ \\
\hline GPX & $\mathrm{BD}$ & 1 & BD & $\mathrm{BD}$ & 5 & $\mathrm{BD}$ & $\mathrm{BD}$ & 4 & $\mathrm{BD}$ & $\mathrm{BD}$ & 11 & $\mathrm{BD}$ & $\mathrm{BD}$ & 29 & $\mathrm{BD}$ \\
\hline GSR & 11 & 39 & $\mathrm{BD}$ & 23 & 47 & $\mathrm{BD}$ & 13 & 27 & $\mathrm{BD}$ & 21 & 73 & $\mathrm{BD}$ & 54 & 95 & 12 \\
\hline GSTtheta & 335 & 350 & 213 & 355 & 431 & 313 & 339 & 439 & 217 & 336 & 384 & 295 & 296 & 366 & 216 \\
\hline HSP71 & 2191 & 2629 & 1976 & 2069 & 2462 & 1877 & 2176 & 2534 & 1799 & 1999 & 2740 & 1723 & 1992 & 2368 & 1554 \\
\hline HSP90B & 1500 & 1616 & 1296 & 1538 & 1691 & 1327 & 1521 & 1684 & 1282 & 1473 & 1686 & 1274 & 1535 & 1766 & 1333 \\
\hline IL1b & $\mathrm{BD}$ & $\mathrm{BD}$ & $\mathrm{BD}$ & $\mathrm{BD}$ & $\mathrm{BD}$ & $\mathrm{BD}$ & $\mathrm{BD}$ & $\mathrm{BD}$ & $\mathrm{BD}$ & $\mathrm{BD}$ & $\mathrm{BD}$ & $\mathrm{BD}$ & $\mathrm{BD}$ & $\mathrm{BD}$ & $\mathrm{BD}$ \\
\hline PCNA & $\mathrm{BD}$ & $\mathrm{BD}$ & $\mathrm{BD}$ & $\mathrm{BD}$ & 6 & $\mathrm{BD}$ & $\mathrm{BD}$ & 7 & $\mathrm{BD}$ & $\mathrm{BD}$ & 5 & $\mathrm{BD}$ & $\mathrm{BD}$ & 5 & $\mathrm{BD}$ \\
\hline SOD & 9 & 33 & $\mathrm{BD}$ & 7 & 30 & $\mathrm{BD}$ & $\mathrm{BD}$ & 29 & $\mathrm{BD}$ & 7 & 20 & $\mathrm{BD}$ & 10 & 30 & $\mathrm{BD}$ \\
\hline TGFB & BD & BD & BD & BD & BD & BD & BD & $\mathrm{BD}$ & BD & $\mathrm{BD}$ & $\mathrm{BD}$ & $\mathrm{BD}$ & $\mathrm{BD}$ & 15 & $\mathrm{BD}$ \\
\hline
\end{tabular}




\begin{tabular}{|c|c|c|c|c|c|c|c|c|c|c|c|c|c|c|c|}
\hline & \multicolumn{15}{|c|}{24 Hour } \\
\hline & \multicolumn{3}{|c|}{ Control } & \multicolumn{3}{|c|}{ Low } & \multicolumn{3}{|c|}{ Med } & \multicolumn{3}{|c|}{ High } & \multicolumn{3}{|c|}{ Severe } \\
\hline & Median & Max & Min & Median & Max & Min & Median & Max & Min & Median & Max & Min & Median & Max & Min \\
\hline CAT & 121 & 239 & 89 & 137 & 235 & 72 & 103 & 259 & 79 & 123 & 317 & 83 & 101 & 149 & 67 \\
\hline CYP1A & 151 & 399 & 105 & 149 & 373 & 109 & 135 & 425 & 65 & 150 & 401 & 102 & 102 & 154 & 27 \\
\hline CYP3A & 2085 & 3236 & 1236 & 2215 & 3359 & 1280 & 2137 & 3644 & 1279 & 2163 & 3673 & 1277 & 1500 & 2525 & 749 \\
\hline GSTrho & $\mathrm{BD}$ & 2 & $\mathrm{BD}$ & $\mathrm{BD}$ & $\mathrm{BD}$ & $\mathrm{BD}$ & $\mathrm{BD}$ & $\mathrm{BD}$ & $\mathrm{BD}$ & $\mathrm{BD}$ & $\mathrm{BD}$ & $\mathrm{BD}$ & $\mathrm{BD}$ & $\mathrm{BD}$ & $\mathrm{BD}$ \\
\hline GLK & 41 & 230 & 9 & 27 & 225 & $\mathrm{BD}$ & 25 & 197 & $\mathrm{BD}$ & 26 & 196 & $\mathrm{BD}$ & $\mathrm{BD}$ & 54 & $\mathrm{BD}$ \\
\hline GPX & $\mathrm{BD}$ & 6 & $\mathrm{BD}$ & $\mathrm{BD}$ & 2 & BD & $\mathrm{BD}$ & $\mathrm{BD}$ & $\mathrm{BD}$ & $\mathrm{BD}$ & 8 & $\mathrm{BD}$ & $\mathrm{BD}$ & $\mathrm{BD}$ & $\mathrm{BD}$ \\
\hline GSR & 35 & 74 & 9 & 36 & 72 & 4 & 23 & 49 & $\mathrm{BD}$ & 47 & 64 & $\mathrm{BD}$ & 77 & 119 & $\mathrm{BD}$ \\
\hline GSTtheta & 202 & 265 & 124 & 220 & 264 & 144 & 208 & 264 & 163 & 192 & 215 & 131 & 189 & 209 & 135 \\
\hline HSP71 & 2465 & 2860 & 1814 & 2432 & 2705 & 1744 & 2315 & 3148 & 1765 & 2680 & 3563 & 1940 & 2490 & 3090 & 1863 \\
\hline HSP90B & 1641 & 1998 & 1330 & 1719 & 1851 & 1327 & 1697 & 1883 & 1410 & 1745 & 2006 & 1344 & 1938 & 2324 & 1503 \\
\hline IL1b & $\mathrm{BD}$ & $\mathrm{BD}$ & $\mathrm{BD}$ & BD & $\mathrm{BD}$ & $\mathrm{BD}$ & $\mathrm{BD}$ & $\mathrm{BD}$ & $\mathrm{BD}$ & $\mathrm{BD}$ & BD & BD & $\mathrm{BD}$ & $\mathrm{BD}$ & $\mathrm{BD}$ \\
\hline PCNA & $\mathrm{BD}$ & 8 & $\mathrm{BD}$ & $\mathrm{BD}$ & BD & $\mathrm{BD}$ & $\mathrm{BD}$ & $\mathrm{BD}$ & $\mathrm{BD}$ & $\mathrm{BD}$ & 7 & $\mathrm{BD}$ & $\mathrm{BD}$ & 1 & $\mathrm{BD}$ \\
\hline SOD & 24 & 60 & BD & 23 & 41 & $\mathrm{BD}$ & 10 & 40 & $\mathrm{BD}$ & 22 & 41 & $\mathrm{BD}$ & 7 & 26 & $\mathrm{BD}$ \\
\hline TGFB & $\mathrm{BD}$ & $\mathrm{BD}$ & $\mathrm{BD}$ & $\mathrm{BD}$ & $\mathrm{BD}$ & $\mathrm{BD}$ & $\mathrm{BD}$ & $\mathrm{BD}$ & $\mathrm{BD}$ & $\mathrm{BD}$ & $\mathrm{BD}$ & $\mathrm{BD}$ & $\mathrm{BD}$ & $\mathrm{BD}$ & $\mathrm{BD}$ \\
\hline
\end{tabular}


Table 6. Contig summary (by immunostimulant) for the generation of reference transcriptome based on leukocyte stimulation.

\begin{tabular}{|l|r|l|l|}
\hline Sample & $\begin{array}{l}\text { Insert } \\
\text { Size }\end{array}$ & $\begin{array}{l}\text { Total } \\
\text { Reads }\end{array}$ & Bases \\
\hline Control & 394 & $226,613,464$ & $34,218,633,064$ \\
\hline Poly I:C & 388 & $207,461,274$ & $31,326,652,374$ \\
\hline PHA-P & 412 & $186,103,334$ & $28,101,603,434$ \\
\hline Zymosan & 410 & $216,455,450$ & $32,684,772,950$ \\
\hline
\end{tabular}


Table 7. Median, maximum, and minimum transcript abundance counts for specific genes of interest in the leukocyte challenge. Significance was determined among treatment and within each transcript. Significance codes represent differences among treatment groups within each treatment. Data below the detection limit of the assay are presented as BD.

\begin{tabular}{|c|c|c|c|c|c|c|c|c|c|}
\hline \multicolumn{10}{|c|}{ Treatment } \\
\hline & & $\begin{array}{l}\varrho \\
\stackrel{0}{0} \\
\stackrel{0}{0}\end{array}$ & $\overline{\mathbf{Z}}$ & $\begin{array}{l}\frac{3}{2} \\
\frac{3}{1} \\
\frac{3}{1}\end{array}$ & $\begin{array}{l}3 \\
\stackrel{3}{2} \\
\stackrel{3}{3} \\
\stackrel{3}{3}\end{array}$ & 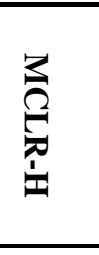 & 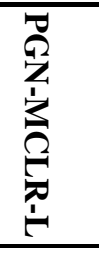 & 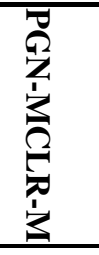 & 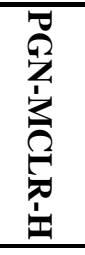 \\
\hline \multirow{4}{*}{ ת } & Median & $\mathrm{BD}$ & 24 & $\mathrm{BD}$ & $\mathrm{BD}$ & 12 & 49 & 27 & 20 \\
\hline & Significance & $\mathrm{a}$ & $\mathrm{ac}$ & $\mathrm{a}$ & $\mathrm{a}$ & $\mathrm{ac}$ & c & $\mathrm{ac}$ & $\mathrm{ac}$ \\
\hline & Max & 19 & 46 & 33 & 36 & 44 & 61 & 62 & 47 \\
\hline & Min & $\mathrm{BD}$ & $\mathrm{BD}$ & $\mathrm{BD}$ & $\mathrm{BD}$ & $\mathrm{BD}$ & 13 & $\mathrm{BD}$ & $\mathrm{BD}$ \\
\hline \multirow{4}{*}{ نِّ } & Median & 991 & 3693 & 832 & 880 & 773 & 3927 & 4316 & 4515 \\
\hline & Significance & $\mathrm{a}$ & $\mathrm{b}$ & $\mathrm{a}$ & $\mathrm{a}$ & $\mathrm{a}$ & $\mathrm{b}$ & $\mathrm{b}$ & $\mathrm{b}$ \\
\hline & Max & 1406 & 4890 & 1991 & 1539 & 1463 & 5346 & 5024 & 6476 \\
\hline & Min & 428 & 2435 & 310 & 279 & 338 & 2918 & 2693 & 3049 \\
\hline \multirow{4}{*}{$\widetilde{\widetilde{\Xi}}$} & Median & 40 & $\mathrm{BD}$ & $\mathrm{BD}$ & 31 & 44 & 8 & $\mathrm{BD}$ & $\mathrm{BD}$ \\
\hline & Significance & $\mathrm{a}$ & $\mathrm{ab}$ & $\mathrm{ab}$ & $a b$ & $\mathrm{a}$ & $\mathrm{b}$ & $\mathrm{b}$ & $\mathrm{a}$ \\
\hline & Max & 131 & 63 & 112 & 49 & 70 & 14 & 26 & 56 \\
\hline & Min & 12 & $\mathrm{BD}$ & $\mathrm{BD}$ & $\mathrm{BD}$ & 20 & $\mathrm{BD}$ & $\mathrm{BD}$ & $\mathrm{BD}$ \\
\hline \multirow{4}{*}{ 文 } & Median & $\mathrm{BD}$ & 130 & 2 & 14 & 28 & 175 & 141 & 174 \\
\hline & Significance & $\mathrm{a}$ & $\mathrm{b}$ & $\mathrm{a}$ & $\mathrm{a}$ & $\mathrm{a}$ & $\mathrm{b}$ & $\mathrm{b}$ & $\mathrm{b}$ \\
\hline & Max & 40 & 196 & 38 & 46 & 43 & 230 & 215 & 311 \\
\hline & Min & $\mathrm{BD}$ & 80 & $\mathrm{BD}$ & $\mathrm{BD}$ & 10 & 77 & 83 & 69 \\
\hline \multirow{4}{*}{$\stackrel{\theta}{\frac{1}{\theta}}$} & Median & 77 & 594 & 213 & 243 & 224 & 779 & 747 & 978 \\
\hline & Significance & $\mathrm{a}$ & $\mathrm{bc}$ & $\mathrm{ac}$ & $\mathrm{ac}$ & $\mathrm{ac}$ & $\mathrm{b}$ & $\mathrm{b}$ & $\mathrm{b}$ \\
\hline & Max & 276 & 817 & 412 & 352 & 406 & 873 & 995 & 1149 \\
\hline & Min & BD & 185 & 91 & 125 & 155 & 360 & 343 & 162 \\
\hline
\end{tabular}




\begin{tabular}{|c|c|c|c|c|c|c|c|c|c|}
\hline \multicolumn{10}{|c|}{ Treatment } \\
\hline & & $\stackrel{\varrho}{\stackrel{0}{0}}$ & $\begin{array}{l}\bar{Z} \\
\bar{Z}\end{array}$ & $\stackrel{3}{2}$ & $\begin{array}{l}3 \\
3 \\
3 \\
3 \\
3\end{array}$ & $\stackrel{3}{3}$ & 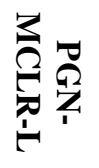 & 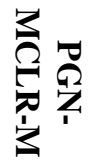 & 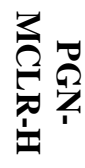 \\
\hline \multirow{4}{*}{ 兄 } & Median & 6 & 29 & BD & 8 & 29 & 58 & 25 & 24 \\
\hline & Significance & $\mathrm{a}$ & $\mathrm{b}$ & $a b$ & $a b$ & $a b$ & $a b$ & $a b$ & $a b$ \\
\hline & Max & 27 & 40 & 69 & 35 & 57 & 68 & 50 & 50 \\
\hline & Min & $\mathrm{BD}$ & $\mathrm{BD}$ & $\mathrm{BD}$ & $\mathrm{BD}$ & 4 & $\mathrm{BD}$ & $\mathrm{BD}$ & $\mathrm{BD}$ \\
\hline \multirow{4}{*}{$\frac{\infty}{n}$} & Median & $\mathrm{BD}$ & 36 & 14 & 28 & 43 & 80 & 47 & 36 \\
\hline & Significance & $\mathrm{a}$ & $a b$ & $a b$ & $a b$ & $\mathrm{~b}$ & $a b$ & $\mathrm{~b}$ & $a b$ \\
\hline & Max & 30 & 62 & 50 & 55 & 63 & 104 & 85 & 83 \\
\hline & Min & $\mathrm{BD}$ & $\mathrm{BD}$ & BD & BD & 14 & 1 & 16 & $\mathrm{BD}$ \\
\hline \multirow{4}{*}{$\begin{array}{l}\overline{\mathbf{S}} \\
\mathbf{Z}\end{array}$} & Median & 69 & 60 & 97 & 136 & 119 & 95 & 73 & 64 \\
\hline & Significance & $\mathrm{a}$ & $\mathrm{a}$ & $a b$ & $\mathrm{~b}$ & $\mathrm{~b}$ & $a b$ & $a b$ & $\mathrm{a}$ \\
\hline & $\operatorname{Max}$ & 110 & 76 & 141 & 204 & 176 & 123 & 119 & 103 \\
\hline & Min & $\mathrm{BD}$ & 35 & 44 & 94 & 106 & 29 & 26 & 4 \\
\hline \multirow{4}{*}{ Ũ } & Median & $\mathrm{BD}$ & 40 & $\mathrm{BD}$ & $\mathrm{BD}$ & 15 & 94 & 73 & 63 \\
\hline & Significance & $\mathrm{ac}$ & $\mathrm{bc}$ & $\mathrm{ac}$ & $\mathrm{a}$ & $\mathrm{c}$ & $\mathrm{b}$ & $\mathrm{b}$ & $\mathrm{b}$ \\
\hline & Max & 11 & 79 & 72 & 42 & 46 & 157 & 145 & 161 \\
\hline & Min & $\mathrm{BD}$ & 22 & $\mathrm{BD}$ & BD & 2 & 26 & 28 & 34 \\
\hline \multirow{4}{*}{ 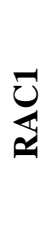 } & Median & $\mathrm{BD}$ & 13 & $\mathrm{BD}$ & BD & 17 & 32 & 19 & $\mathrm{BD}$ \\
\hline & Significance & $\mathrm{a}$ & $\mathrm{ab}$ & $a b$ & $\mathrm{ab}$ & $\mathrm{ab}$ & $\mathrm{b}$ & $a b$ & $a b$ \\
\hline & Max & 15 & 33 & 31 & 32 & 26 & 57 & 33 & 27 \\
\hline & Min & $\mathrm{BD}$ & BD & $\mathrm{BD}$ & $\mathrm{BD}$ & $\mathrm{BD}$ & $\mathrm{BD}$ & $\mathrm{BD}$ & $\mathrm{BD}$ \\
\hline \multirow{4}{*}{$\begin{array}{l}\text { D̂ } \\
\text { ర్ }\end{array}$} & Median & $\mathrm{BD}$ & 53 & $\mathrm{BD}$ & 6 & 16 & 92 & 61 & 40 \\
\hline & Significance & $\mathrm{a}$ & $\mathrm{cd}$ & $\mathrm{ac}$ & $\mathrm{ac}$ & $\mathrm{ac}$ & bde & $\mathrm{bc}$ & ace \\
\hline & Max & 45 & 64 & 63 & 66 & 63 & 119 & 86 & 83 \\
\hline & Min & $\mathrm{BD}$ & 9 & $\mathrm{BD}$ & $\mathrm{BD}$ & $\mathrm{BD}$ & 45 & $\mathrm{BD}$ & $\mathrm{BD}$ \\
\hline \multirow{4}{*}{$\stackrel{v}{\underline{3}}$} & Median & $\mathrm{BD}$ & $\mathrm{BD}$ & $\mathrm{BD}$ & $\mathrm{BD}$ & 2 & 16 & $\mathrm{BD}$ & $\mathrm{BD}$ \\
\hline & Significance & $\mathrm{b}$ & $a b$ & $a b$ & $\mathrm{ab}$ & $a b$ & $\mathrm{a}$ & $a b$ & $\mathrm{~b}$ \\
\hline & Max & 2 & 11 & 28 & 20 & 8 & 36 & 25 & 5 \\
\hline & Min & BD & $\mathrm{BD}$ & $\mathrm{BD}$ & BD & $\mathrm{BD}$ & $\mathrm{BD}$ & BD & $\mathrm{BD}$ \\
\hline
\end{tabular}




\begin{tabular}{|c|c|c|c|c|c|c|c|c|c|}
\hline \multicolumn{10}{|c|}{ Treatment } \\
\hline & & $\begin{array}{c}\varrho \\
\stackrel{0}{0} \\
\stackrel{0}{0}\end{array}$ & $\overrightarrow{\mathbf{Z}}$ & $\frac{3}{2}$ & $\begin{array}{l}3 \\
3 \\
3 \\
3 \\
3 \\
3\end{array}$ & 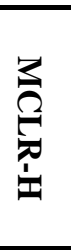 & 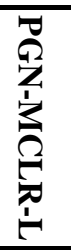 & 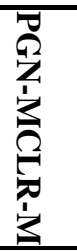 & 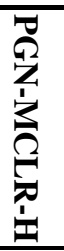 \\
\hline \multirow{4}{*}{ 苚 } & Median & $\mathrm{BD}$ & $\mathrm{BD}$ & BD & BD & BD & 20 & 3 & $\mathrm{BD}$ \\
\hline & Significance & $\mathrm{a}$ & $a b$ & $a b$ & $a b$ & $a b$ & $\mathrm{~b}$ & $a b$ & $a b$ \\
\hline & Max & 7 & 20 & 36 & 20 & 27 & 34 & 23 & 27 \\
\hline & Min & BD & BD & BD & BD & BD & BD & BD & BD \\
\hline \multirow{4}{*}{ 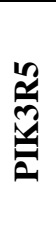 } & Median & $\mathrm{BD}$ & $\mathrm{BD}$ & $\mathrm{BD}$ & BD & BD & 12 & 1 & $\mathrm{BD}$ \\
\hline & Significance & $\mathrm{a}$ & $a b$ & $a b$ & $a b$ & $a b$ & $\mathrm{~b}$ & $\mathrm{ab}$ & $a b$ \\
\hline & Max & BD & 5 & 11 & 20 & 16 & 36 & 12 & 8 \\
\hline & Min & $\mathrm{BD}$ & $\mathrm{BD}$ & $\mathrm{BD}$ & $\mathrm{BD}$ & BD & BD & $\mathrm{BD}$ & $\mathrm{BD}$ \\
\hline
\end{tabular}




\title{
Chapter Four. Associations among estrogenic activity, select chemical compounds and microcystin toxins in the Potomac River drainage, USA
}

\begin{abstract}
A suite of compounds identified to interfere with hormone pathways are termed endocrine disrupting compounds (EDCs). Considerable attention has been directed towards estrogenic chemicals in the environment within the Chesapeake Bay watershed. We quantified the net cumulative effects of these compounds in mixtures using a bioluminescent yeast estrogenicity screen (BLYES). Samples were collected at 15 sites through the middle and upper Potomac River basin and quantified the estrogenic equivalency potential in the water column. Data are presented as the estrogenic equivalency of strain Saccharomyces cerevisiae BLYES as compared to a $17 \beta$-estradiol standard curve (EEQ BLYES $_{\text {) }}$ and ranged from BD - $5.75 \mathrm{ng} / \mathrm{L}$. We observed considerable seasonal variability reporting data higher in the summer months. Estrogenicity was positively correlated with temperature; however, there were no significant correlations among discharge, $\mathrm{pH}$, conductivity, total nitrogen or total phosphorous in the water column or benthos. The EEQ $\mathrm{BLyES}$ was positively correlated with equol. Additionally, EEQ BLYES was positively correlated with total microcystins/nodularins and we verified that purified microcystin variant -LR was not estrogenic by this assay. We assessed EEQBLYES in the context of land cover/land use and did not observe any significant correlations in any of our sampling watersheds. These data highlight temporal changes in estrogenicity at these sites. They also show a contribution from phytoestrogens to the instream estrogenicity. Both of these should be taken into account when quantifying environmental estrogenicity.
\end{abstract}




\section{Introduction}

Endocrine disrupting compounds (EDCs) have been identified in surface waters throughout the United States (Kolpin et al. 2002, Snow et al. 2010). A subset of these compounds termed estrogenic endocrine disrupting compounds (EEDCs) has been shown to modulate estrogen receptor-mediated pathways in aquatic organisms (Campbell et al. 2006). Examples of EEDC include both steroidal and non-steroidal compounds. Many of these compounds have been correlated to adverse biological effects in fishes (Segner et al. 2013, Senthilkumaran 2015). The specific sources and fate of these EEDCs in surface waters is important in understanding their environmental impact and potential management (Adeel et al. 2017). Biological assays (specifically yeast-based assays) are incorporated to monitor EEDCs ( Murk et al. 2002, Petrovic et al. 2004, Vigano et al. 2008, Di Paolo et al. 2016).

Extensive research has been conducted in the Chesapeake Bay watershed focusing on the associations of EEDCs with biological effects in aquatic organisms. Blazer et al. (2007) report widespread testicular oocyte (TO) occurrence and severity in smallmouth bass (SMB; Micropterus dolomieu) within the Potomac River watershed. They note that this system is dominated by agricultural input. Iwanowicz et al. (2009) further studied TO and noted a high occurrence of TO regardless of proximity to wastewater treatment facilities (WWTP). This would suggest that other inputs may be driving endocrine disruption. Recent research has highlighted the association of agricultural operations (such as confined animal feedlot operations) with estrogenicity (Blazer et al. 2012, Ciparis et al. 2012, Young et al. 2014). A variety of compounds are associated with agricultural land use (Zhang et al. 2015). One extensively studied pesticide that has been shown to induce TO is atrazine (Hayes et al. 2011). Kolpin et al. (2013) documented the occurrence of atrazine in the Potomac River watershed and 
identified a significant positive correlation with TO in male smallmouth bass. Other EEDCs were identified as well. Some of this sampling occurred proximate to SMB nesting sites. The presence and concentration of these bioactive compounds are an important component for associating the biological effects potential in the environment.

Agricultural inputs are not limited to high density animal excretions and land applied pesticides. Phytoestrogens are also present in agricultural settings. These are a group of nonsteroidal compounds produced by plants and other photosynthetic organisms. Chemically they are structurally similar to estrogens and some are known to interact with estrogen receptors and modulate ER-mediated signaling pathways ( Verdeal and Ryan 1979, Morito et al. 2001, Cappelletti et al. 2006, Lecomte et al. 2017). Legumes and agricultural crops have been principally identified as producing these compounds (Franke et al. 1994, Jarosova et al. 2015, Kang and Price 2009, Kolpin et al. 2010, Kuhnle et al. 2009, Liu et al. 2010). However, the presence of phytoestrogens is not strictly limited to agricultural operations. For example, equol is a bacterial metabolite of the soy isoflavones daidzin and daidzein (Setchell and Clerici 2010). It is released in the waste of animals containing these bacteria and can occur in humans, livestock, and in the wild. Thus, occurrence in the environment may be linked to point- and non-point source contamination. The specific timing and magnitude of release of these compounds into surface waters is poorly understood. For example, Rearick et al. (2014) were unable to report a discernible temporal or spatial trend in select phytoestrogens; however, they did note that phytoestrogens could be detected in anthropologically impacted streams and absent from reference streams.

Other possible, but lesser investigated sources of EEDCs are the instream algal communities. The frequency of algal blooms in aquatic environments has increased over time as 
a result of elevated temperatures and available eutrophication (O'Neil et al. 2012); and harmful algal blooms are a significant matter of public health (Carmichael and Boyer 2016, Grattan et al. 2016). One critical component to the public health aspect of harmful algal blooms is the production of toxins by select species (particularly cyanobacteria). Microcystin (MC) is a secondary metabolite of select cyanobacteria species and best recognized as a potent hepatotoxin (Sierosławska 2010). Oziol and Bouaicha (2010) showed the microcystin (MC) variant -LR (MC-LR) to cause an increase in estrogenic activity in culture via classical estrogen receptor mediated signaling. Interestingly, lysates from both cyanobacteria and true algae have been shown to be estrogenic in vitro (Štěpánková et al. 2011, Sychrová et al. 2012). The contribution of algae should be considered when assessing the total instream estrogenicity.

The objective of this research was to monitor the temporal and spatial distribution of estrogenic compounds in the middle and upper Potomac River watershed, and identify possible associations with land cover/land use. This estrogenic signal was compared to the occurrence of common phytoestrogens and steroidal estrogens, as well as total microcystin/nodularin toxins. A secondary objective was to compare the estrogenic signal to both physical and nutrient parameters.

\section{Methods}

\subsection{Field collection}

Fifteen sites along streams located within the Potomac River watershed in West Virginia, Maryland, and Virginia were selected for surface water sampling based on the historic presence of EEDCs or sites of interest by fisheries biologist staff from the West Virginia Division of Natural Resources. Here we define these as the reconnaissance sites. The 15 reconnaissance sites 
were sampled monthly from June 26, 2013 through June 18, 2014 (Figure 1). Two grab water samples were collected from a near-shore location using one chemically clean $1 \mathrm{~L}$ amber glass bottle (I-Chem, Rockwood, Tennessee). These will be referred to as filtered water samples. Water temperature $\left({ }^{\circ} \mathrm{C}\right), \mathrm{pH}$, conductivity $(\mu \mathrm{S} / \mathrm{cm})$, total dissolved oxygen $(\mathrm{mg} / \mathrm{L}$ and percent), and discharge $\left(\mathrm{ft}^{3} / \mathrm{s}\right)$ were recorded at each site. Additional water samples were collected in chemically clean $1 \mathrm{~L}$ amber glass bottles for analytical chemistry. This was performed at 2 sites on the South Branch of the Potomac River monthly between July 9, 2013 and August 11, 2014 (Figure 1). These water samples were filtered using a $0.7 \mu \mathrm{m}$ AP40 GF/F filter (Millipore Corporation, Billerica, Massachusetts) to remove coarse and fine particulates and stored at $-20^{\circ} \mathrm{C}$. Frozen samples were then shipped to the USGS Kansas Water Science Center (Lawrence, Kansas) for analysis of steroidal estrogens (17- $\beta$ estradiol (E2), and estrone (E1)), as well as the isoflavones genestein, daidzein, formonentin, equol, and biochain $\mathrm{A}$.

A subset of three reconnaissance sites was selected to increase the temporal resolution and sampled biweekly for 16 months (Figure 1). Locations sampled during this phase of the study are defined as biweekly sites. Biweekly sampling occurred between June 30, 2014 and December 14, 2015. We collected an additional discrete water sample in one clean sterile 500 mL HDPE bottle (Thermo Fisher Scientific, Waltham, Massachusetts) in addition to the physical parameters described above, beginning with the first sampling date in 2015 (January 13th) through the final collection date (December 14th). These samples were defined as unfiltered. Filtered samples contain acellular EEDCs present in the water column while unfiltered samples contain cellular and acellular analytes.

We also measured total nitrogen $(\mathrm{N} ; \mathrm{mg} / \mathrm{L})$, total phosphorous $(\mathrm{P} ; \mathrm{mg} / \mathrm{L})$, and total dissolved phosphorous (TDP; $\mathrm{mg} / \mathrm{L}$ ) in the water column from the biweekly collections. In 
addition, sediment $\mathrm{N}(\mathrm{mg} / \mathrm{kg})$ and $\mathrm{P}(\mathrm{mg} / \mathrm{kg})$ was also measured. Water was collected in sterile $500 \mathrm{~mL}$ HDPE bottles (Thermo Fisher Scientific, Waltham, Massachusetts) while sediment was collected in $250 \mathrm{~mL}$ pre-cleaned to EPA standards glass amber bottles (Quality Environmental Containers, Beaver, West Virginia). Both samples were stored at $4^{\circ} \mathrm{C}$ for no more than 14 days prior shipment to Research Environmental Industrial Consultants Inc. (Beaver, West Virginia) for analysis.

\subsection{Laboratory preparation}

Filtered water samples were adjusted to $\mathrm{pH} 3.0$ with $6 \mathrm{~N}$ hydrochloric acid and stored at $4^{\circ} \mathrm{C}$. All samples were extracted within two weeks of collection (Havens et al. 2010). Unfiltered water samples were subjected to three freeze-thaw cycles to room temperature to disrupt the cells (Graham et al. 2010, Loftin et al. 2008).

Filtered and unfiltered water samples were extracted using methods modified from Ciparis et al. (2012). Briefly, all water samples were filtered with a $0.7 \mu \mathrm{m} \mathrm{AP40} \mathrm{GF/F} \mathrm{filter}$ (Millipore Corporation, Billerica, Massachusetts) prior to extraction to remove coarse particulates (unfiltered water samples were adjusted to $\mathrm{pH} 3.0$ with $6 \mathrm{~N}$ hydrochloric acid prior to filtration). We then prepared water samples by solid phase extraction (SPE) using OASIS® HLB (200mg) glass cartridges (Waters Corporation, Milford, Massachusetts). Cartridges were conditioned using $5 \mathrm{~mL}$ each of ethyl acetate, 50:50 methanol:dichloromethane, methanol, and $18 \mathrm{M} \Omega-\mathrm{H}_{2} \mathrm{O} \mathrm{pH}$ 3.0. Then $800 \mathrm{~mL}$ filtered or $400 \mathrm{~mL}$ unfiltered water samples were run through the cartridge by continuous vacuum using methods modified from Laganà et al. (2004). Analytes were eluted with $6 \mathrm{~mL}$ absolute methanol and $6 \mathrm{~mL}$ 50:50 methanol (absolute):dichloromethane and reduced to dryness. Eluates were solubilized in methanol to a final sample concentration of 1600x. Samples were stored at $-20^{\circ} \mathrm{C}$ until analysis. 


\subsection{Bioluminescent Yeast Estrogenicity Screen (BLYES)}

The Saccharomyces cerevisiae Bioluminescent Yeast Estrogenicity Screen (BLYES) was used to quantify total estrogenicity of environmental samples using methods previously described by Ciparis et al. (2012) with modification. Strain BLYES was purchased from 490 Bio Tech (Knoxville, TN). Yeast cultures were grown to early stationary phase in yeast minimal drop-out media (YMM; leu-, ura-) at $30^{\circ} \mathrm{C}$ for 48 hours on a rotary shaker (Routledge and Sumpter 1996). The 48 hour culture was centrifuged at $2000 \mathrm{x}$ g for 10 minutes, re-suspended in fresh YMM, and normalized to an $\mathrm{OD}_{600}$ of 0.40 . The assay was performed in sterile, clear bottom 96-well black plates (Costar, Corning Incorporated, Corning, New York). Sample extracts were diluted to 5\% in YMM and assayed in triplicate. All plates included a 12-point standard curve of E2 that ranged from $10 \mathrm{ng} / \mathrm{mL}$ to $3.4 \mathrm{pg} / \mathrm{mL}$ and included a YMM-only blank. The $\mathrm{OD}_{600}$ normalized yeast reporter was added to all wells (100 $\left.\mu \mathrm{L} / w e l l\right)$. The final concentration of methanol in all assay and standard wells was $2.5 \%$. Plates were incubated for 4 hours at $30^{\circ} \mathrm{C}$ on an orbital shaker. Luminescence was quantified using a SpectraMax M4 (Molecular Devices, Sunnyvale, California) with the integration time at 500 milliseconds and automatic photo multiplier tube gain. Sample concentrations were interpolated from the standard curve in SoftMaxPro v6.2.2 (Molecular Devices, Sunnyvale, California) using a 4-parameter logistic regression. Sample concentrations were then back calculated based on sample dilution.

The detection limit (LoD) and reporting limit (LoQ) were determined based on 20 randomly selected standard curves generated over a 2-year period. The LoD was defined as the minimum detection limit plus one standard deviation. When corrected for sample concentration, the LoD was $0.145 \mathrm{ng} / \mathrm{L}$. The LoQ based on E2 was defined as the minimum detection limit plus 
three standard deviations and corrected for starting water volume was $0.230 \mathrm{ng} / \mathrm{L}$. Data were reported as EEQ BLyes. Data below the LoQ are reported as $0.5 *$ LoD.

We explored the possible relationship between estrogenicity and total MCs using purified microcystin variant-LR (MC-LR; EMD Millipore, Burlington, Massachusetts) at environmentally relevant concentrations ranging from $5 \mathrm{fg} / \mathrm{mL}$ to $500 \mathrm{ng} / \mathrm{mL}$.

\subsection{Direct competitive enzyme-linked immunosorbent assay (ELISA) protocol}

We developed an ELISA specific for the ADDA side chain present in microcystins and nodularins synthesized by some cyanobacteria. This method was adaptated from Campas and Marty (2007). Wells were coated with $100 \mu \mathrm{L}$ of ADDA-specific monoclonal antibody (0.1 $\mu \mathrm{g} / \mathrm{mL}$; AD4G2; Enzo Life Sciences, Farmingdale, New York) and incubated in a 96-well ELISA plate (Costar® 3396, Corning Inc., Corning, New York) for 18 hours at $4^{\circ} \mathrm{C}$. Plates were washed five times with tris-buffered saline plus 0.5\% v/v Tween-20 (TBST; pH 7.4), and blocked with TBST plus $1 \%$ bovine serum albumin (block buffer $\mathrm{pH} 7.4$ ) for 2 hours at $37^{\circ} \mathrm{C}$. Each plate was washed 5 times with TBST and $50 \mu \mathrm{L}$ of standards or sample was added at a $5 \%$ dilution in block buffer. We then added $50 \mu \mathrm{L}$ of biotin-labelled MC-LR to each well at a concentration of $4 \mu \mathrm{g} / \mathrm{mL}$ in block buffer and incubated for 1.5 hours at $37^{\circ} \mathrm{C}$. Plates were washed 5 times with TBST and $100 \mu \mathrm{L}$ of streptavidin-horseradish peroxidase conjugate (1:5000 in block buffer; ThermoFisher Scientific, Waltham, Massachusetts) was added and incubated for 30 minutes at $37^{\circ} \mathrm{C}$. Plates were washed 5 times with TBST and $100 \mu \mathrm{L}$ of SureBlue Reserve ${ }^{\mathrm{TM}}$ TMB Microwell Peroxidase Substrate (Kirkegaard \& Perry Laboratories, Inc., Gaithersburg, Maryland) was added and incubated at $25^{\circ} \mathrm{C}$ for 1.5 hours. Finally, $50 \mu \mathrm{L}$ of TMB stop solution (Kirkegaard \& Perry Laboratories, Inc., Gaithersburg, Maryland) was added and plates were read 
at $450 \mathrm{~nm}$ with a SpectraMax M4 plate reader (Molecular Devices LLC, Sunnyvale, California). Data are reported as total MC/NOD due to non-specificity of the mAb.

\subsection{Spatial analysis}

Land cover/land use was determined using the U.S. Department of Agriculture Cropland Data Layers from 2013, 2014, and 2015 (USDA 2013, 2014, 2015). We identified the crop cover for each year among the full watershed upstream of our sampling site. We also quantified the crop cover for all three years within a 30 meter buffer around each stream located within the watershed upstream of our sampling site. Land cover types were then grouped into six categories (Table 1). Streams and watersheds were determined using both the National Hydrography Dataset (https://nhd.usgs.gov, accessed 2016), and the National Elevation Dataset (https://lta.cr.usgs.gov/NED; accessed 2016). Wastewater treatment facilities were derived from the U.S. EPA Facility Registry Service (FRS): Wastewater Treatment Plants (https://catalog.data.gov/dataset/epa-facility-registry-service-frs-wastewater-treatment-plants).

\subsection{Statistical analysis}

All data were analyzed using the R statistical software v3.4.3 (R Core Development Team 2017). Significance was determined at $\alpha=0.05$. All variables were assessed for normality using the Shapiro-Wilk test of normality. If variables were not normally distributed, they were transformed with either a $\log _{10}$ or square root transformation. We then determined the correlation between filtered and unfiltered water samples using the Pearson correlation. We analyzed the relationship between filtered and unfiltered water within season/year using a Student's t-test accounting for homogeneity. 
We quantified the association among EEQBLYES in both water fractions among sampling locations using a one-way ANOVA test. We did not observe significant differences in EEQBLYES among our sampling sites in either the reconnaissance or intensive sampling period in filtered water $(\mathrm{p}=0.604$ and 0.160 , respectively) or unfiltered water $(\mathrm{p}=0.077)$.

Because no significant differences were observed among sampling sites, the correlation between estrogenicity (in both water fractions) was assessed among sampling season/year using a one-way ANOVA test. Tukey's honest significant difference tests were used to differentiate significant results. We defined season by the following: spring sampling occurred during March, April, and May; summer sampling occurred during June, July, and August; fall sampling occurred during September, October, and November; winter sampling occurred during December, the following January, and February (the year associated with winter corresponds to January and February). Next we quantified the explanatory variables responsible for each water fraction among each respective sampling time period. This was analyzed using multiple linear regression models given that no significant differences were observed across sites. First, we evaluated estrogenicity in filtered water as a function of stream discharge $\left(\mathrm{m}^{3} / \mathrm{s}\right)$, temperature $\left({ }^{\circ} \mathrm{C}\right)$, conductivity $(\mu \mathrm{S} / \mathrm{cm})$, and $\mathrm{pH}$ during the initial reconnaissance time period. To analyze the subsequent 16 months, we developed two separate models. The first model explored the effects of four physical variables described above on total estrogenicity in both water fractions (independently). The second model incorporated the top candidate model(s) based on significance along with the $\mathrm{N}$ and $\mathrm{P}$ variables. We did not incorporate TDP into the models due to the high frequency of data below the reporting limit (104 of 117 total samples).

The two locations in which estrogenic compounds E2, E1, genestein, daidzein, formonentin, equol, and biochain A were quantified were analyzed independently. The 
association between $\mathrm{EEQ}_{\mathrm{BLYES}}$ (in filtered water) and these compounds was quantified using a simple linear regression.

Land cover/land use data are reported annually. Therefore we pooled EEQBLYES and the percent agricultural, developed, and forested (both for the entire basin and within 30m of a stream) among each calendar year. We then qualitatively summarized both the specific and reclassified land cover classifications among each watershed. We quantified the association between EEQBLYES and each land cover grouping using Spearman's rank correlation coefficient. The associations between total MC/NOD and EEQBLYES of field samples were compared using simple linear regression at each of the sites grouped among season/year.

\section{Results}

\subsection{Seasonal/annual variability}

We analyzed 291 filtered water samples and 75 unfiltered water samples. First, we analyzed the correlation among filtered and unfiltered grab water samples. We observed a significant weakly positive correlation among filtered and unfiltered grab water samples ( $\mathrm{p}<$ $0.001 ; r^{2}=0.29 ;$ range: $\left.\mathrm{BD}-2.036 \mathrm{ng} / \mathrm{L}\right)$. There was no difference among filtered or unfiltered water within season/year $(\mathrm{p}>0.05)$. We then quantified the estrogenicity of both water samples above LoD both among site and among season/year (Figure 2). While there were not statistically different among sites within season/year, we did observe considerable variability in filtered EEQBLYES among individual sites; specifically in the summer and autumn 2013. This was driven by the elevated values measured at the three sites: South Branch downstream from Moorefield, West Virginia, South Branch downstream from Franklin, West Virginia, and Mill Creek (Hampshire County, West Virginia) (Table 2). We observed an overall trend for higher values in 
the summer and fall compared to the winter and spring. We also note a slight reduction in estrogenicity from 2013 through to 2015 although this was not statistically significant.

\subsection{Variability among season/year pooled across sites}

We did not observe a significant difference among sampling season/year during the reconnaissance sampling period $(\mathrm{p}=0.296)$; however, we did observe a difference among sites in the biweekly sampling period $(\mathrm{p}=0.002$; Table 2). The summer 2014 was significantly higher than the winter and spring 2015. There were no other significant differences. We observed significant difference among sampling season/year in the unfiltered water fraction $(p=0.010)$ during the biweekly period. Spring and summer 2015 were higher than winter 2015 (Table 3).

\subsection{Explanatory variable analysis}

Next, we quantified our estrogenic response variable in the filtered water as a function of the four predictor variables (discharge, temperature, $\mathrm{pH}$, and conductivity) during the initial reconnaissance time period. Among these variables, only water temperature was significantly positively correlated to EEQ $\mathrm{BLYES}(\mathrm{p}=0.002)$. Next, we performed the same analysis during the subsequent intensive sampling period. Again, only temperature was significantly correlated to our response variable $(\mathrm{p}=0.004)$. Finally, we quantified the association among the sediment $\mathrm{N}$ and $\mathrm{P}$, as well as the top variable from above (water temperature) to EEQBLYEs. Water temperature was the only variable significantly correlated in this model $(\mathrm{p}<0.001)$ and it was always a positive association.

We then quantified estrogenicity in unfiltered water as a function of the explanatory variables as described for filtered water. Again, water temperature was the only significantly 
correlated physical variable $(\mathrm{p}=0.002)$ and the only significant variable when included with the two nutrient parameters $(0.017)$.

\subsection{Chemical results summary}

We analyzed estrogenic compounds among two sites (Figure 1). We did not statistically analyze E2 or biochain A due to the low frequency of data above the LoD. Equol was significantly positively correlated with estrogenicity in the water column at the South Branch Potomac River downstream from Petersburg, West Virginia site ( $\mathrm{p}=0.018$; $\mathrm{r} 2=0.42$; Figure 3$)$. There was no statistical association with any other compound to either of these sites. However, upon examining the data, we observed an apparent additive association between E1 and Equol to estrogenicity. Therefore we compared total E1 and equol to estrogenicity and again, only the South Branch Potomac River downstream from Petersburg, West Virginia site was positively correlated to these two estrogenic compounds $\left(\mathrm{p}=0.019 ; \mathrm{r}^{2}=0.42\right)$. Interestingly, we see a stronger association when we extend our analysis to include all five estrogenic compounds $(\mathrm{p}=$ $\left.0.007 ; \mathrm{r}^{2}=0.53\right)$. Water temperature and discharge were inconsistently associated with the five estrogenic compounds we analyzed. We did not observe any significant associations with any compounds at the South Branch Potomac River downstream Moorefield, West Virginia. We observed a weakly inverse correlation among E1 and discharge at the South Branch Potomac River downstream Moorefield, West Virginia site $\left(\mathrm{p}=0.034, \mathrm{r}^{2}=0.29\right)$. There were no other associations between discharge and any other estrogenic variables. We did observe a positive association between temperature and $\mathrm{E} 1\left(\mathrm{p}=0.043, \mathrm{r}^{2}=0.31\right)$, equol $\left(\mathrm{p}=0.034, \mathrm{r}^{2}=0.34\right)$, and the sum of E1/equol $\left(\mathrm{p}=0.027, \mathrm{r}^{2}=0.38\right)$ at the South Branch Potomac River downstream Petersburg, West Virginia site. Temperature was only significantly associated with estrone at the South Branch Potomac River downstream Moorefield, West Virginia site $\left(p=0.002 ; r^{2}=0.55\right)$. 


\subsection{Land cover analysis}

The total basin area among each site ranged between $120.79 \mathrm{~km}^{2}$ and $16229.73 \mathrm{~km}^{2}$ (Tables 4-6). We omitted the "NA", "Open Water" and "Wetlands" classification groupings due to minimal representation on the landscape. Overall, the dominant specific land cover type in each watershed was deciduous forest which comprised between $32 \%-87 \%$ of the overall watershed. Among agricultural land cover types, grass/pasture occurred on the highest percentage of the landscape followed by other hay/non alfalfa, corn, and soybeans. There was no statistical correlation among estrogenicity in the water column and any individual land cover type at either spatial scale $(\mathrm{p}>0.05)$.

\subsection{Comparison of MC-LR and estrogenicity}

MC-LR did not activate the BLYES reporter. However, when we compared environmental samples, we observed a significant positive correlation among estrogenicity and MC/NOD in filtered water at two sites in the water column (Table 2). There was no association between EEQBLyEs and MC/NOD in unfiltered water samples. When independently pooled among all sites, both endpoints were greatest during the summer/fall and approached minimum concentrations during the winter/spring (Figures 2 and 4).

\section{Discussion}

Overall, the estrogenicity values we observed were within the ranges recently reported around the Potomac River watershed (Ciparis et al. 2012, Young et al. 2014). It is unclear what accounts for the seasonal pattern we observed. It is unlikely the result of a dilution effect reflecting the higher flows in the winter and spring given that there was no correlation (positive or inverse) between estrogenicity and discharge. Despite the uncertainty surrounding the specific 
cause(s), this seasonality highlights the dynamic nature of environmental samples. Careful consideration should be given to this variability when designing future studies.

We did not observe any association with estrogenicity and land cover/land use. Although this may seem to contradict earlier studies showing an association with agricultural sources, this is likely simply a result of our site selection. Studies such as Young et al. (2014) and Ciparis et al. (2012) asked specific questions regarding land cover/land use and included a gradient across various land use types. Our site selection included ten minimally impacted agricultural sites (South and North Branch Potomac sites), three moderately impacted agricultural sites (all within the Shenandoah River watershed), and one highly impacted agricultural site (Monocacy River). However, we did not include any specific gradient of land use because the specific question we were addressing was the temporal variability across sampling locations. We did not observe statistically significant differences across any of our sites which would suggest that the seasonal pattern we report is consistent regardless of land use among these 15 sites. Further research is needed to specifically examine the temporal distribution of estrogenicity between a gradient of agricultural, urban, and forested land cover/land use types.

We report positive correlations between estrogenicity and the phytoestrogen equol, the sum of equol and estrone, and the sum of all estrogenic compounds only at the South Branch Petersburg site. This would suggest that phytoestrogens and steroidal estrogens are significantly contributing to the observed total estrogenicity at this site. However, these associations were not reported at the South Branch downstream Moorefield site which is located approximately 20 kilometers downstream. This is likely driven by the reporting of $5.75 \mathrm{ng} / \mathrm{L}$ on $11-$ September2013 which is well above the predicted no-effects concentration of $0.73 \mathrm{ng}$ E2/L as suggested by Wu et al. (2014). It is unclear what is responsible for this event. Once this point is removed, a 
similar positive trend in equol and estrone is observed. This likely results from the similarities between the two sites (noting the inclusion of the South Fork of the South Branch Potomac, as well as two WWTPs at the Moorefield site). These additions constitute a nearly 50\% increase in total basin area. We report estrone above the detection limit $(0.25 \mathrm{ng} / \mathrm{L})$ at a higher frequency at the Moorfield site (62\%) as compared to the Petersburg site (36\%). Estrone has been associated with both WWTP effluent (Tan et al. 2007) and animal waste (Raman et al. 2004). Estrone reports a ten-fold weaker response in strain S. cerevisiae BLYES as compared to $17 \beta$-estradiol (Sanseverino et al. 2009). Therefore, it is unclear what net effects estrone may be having on our reported estrogenicity when combined with equol and the three other estrogenic compounds. Our analysis only included select steroidal hormones and phytoestrogens which were able to show associations with estrogenicity. However, given the discrete event described above which was not associated with the chemicals we quantified, further research should include a more comprehensive list of estrogenic compounds.

We observed a similar seasonal trend between estrogenicity and total MC/NOD; however, purified MC-LR did not report any estrogenic effect with the BLYES assay. However both report the same seasonal signal and both are positively correlated with stream temperature. Cyanobacteria are found in many aquatic habitats worldwide (Chorus and Bartram 1999). Focus of these species is largely on the toxins they produce (Codd et al. 2005), as well as the reduced dissolved oxygen associated with bloom failure. An emerging caveat of cyanobacterial presence is their possible contribution to the estrogenic potential of a stream. The estrogenic potential of cyanobacteria should be considered when explaining the total EEQ of a stream. For example, Procházková et al. (2017) quantified the phytoestrogens present in water bodies which were dominated by cyanobacteria (which included the five flavonoids we quantified). Although they 
identified phytoestrogens in all sites, these were not sufficient to explain the total EEQ they observed. They went on to describe the total phytoestrogen contribution (>10\%) and suggested that additional sources were likely from anthropogenic pathways. Although these were observed in lentic systems, it does elucidate the potential for the environmental estrogenic contribution from phytoestrogens.

Both cyanobacteria and green algae have been associated with estrogen receptor signaling (Štěpánková et al. 2011, Sychrová et al. 2012). They have also been shown to exhibit possible synergistic and/or antagonistic effects on ER when challenged in mixtures. Given the temporal variability among algal communities as reviewed by Fogg (1975), this may explain the seasonal trends we observe. The predominant estrogenic signal we observed occurred between late spring and early fall which may indicate optimal growing temperature. Further research into the specific estrogenic potential among the algal species present within our samples is needed to accurately quantify their contribution.

Finally, any discussion involving cyanobacterial growth must include mention of nutrients. Considerable attention has been directed at documenting and curbing nitrogen $(\mathrm{N})$ and phosphorous (P) in the environment. We did not observe any correlation among EEQBLYEs and total $\mathrm{N}$ or $\mathrm{P}$ in the water column. This may result from the variable $\mathrm{N}$ fixation abilities of specific taxa present (Fay 1992). We did not observe any correlation among nutrients and MC concentrations which could mean that there was a mixed population of MC-producing cyanobacteria which drowned out the nutrient signal. A second possibility is that the concentrations of nutrients were consistently at or above the biological threshold for those cyanobacteria. Further research is needed to temporally quantify algal richness and abundance to test these hypotheses. 


\section{Literature Cited}

Kolpin, D.W., Furlong, E.T., Meyer, M.T., Thurman, E.M., Zaugg, S.D., Barber, L.B. and Buxton, H.T. (2002) Pharmaceuticals, Hormones, and Other Organic Wastewater Contaminants in U.S. Streams, 1999-2000: A National Reconnaissance. Environmental Science and Technology 36(6), 1202-1211.

Snow, D.D., Bartelt-Hunt, S.L., Brown, D.L., Sangster, J. and Cassada, D.A. (2010) Detection, Occurrence and Fate of Pharmaceuticals and Steroid Hormones in Agricultural Environments. Water Environment Research 82(10), 869-882.

Campbell, C.G., Borglin, S.E., Green, F.B., Grayson, A., Wozei, E. and Stringfellow, W.T. (2006) Biologically directed environmental monitoring, fate, and transport of estrogenic endocrine disrupting compounds in water: A review. Chemosphere 65(8), 1265-1280.

Segner, H., Casanova-Nakayama, A., Kase, R. and Tyler, C.R. (2013) Impact of environmental estrogens on Yfish considering the diversity of estrogen signaling. General and Comparative Endocrinology 191, 190-201.

Senthilkumaran, B. (2015) Pesticide- and sex steroid analogue-induced endocrine disruption differentially targets hypothalamo-hypophyseal-gonadal system during gametogenesis in teleosts - A review. General and Comparative Endocrinology 219, 136-142.

Adeel, M., Song, X., Wang, Y., Francis, D. and Yang, Y. (2017) Environmental impact of estrogens on human, animal and plant life: A critical review. Environment International 99, 107119.

Murk, A.J., Legler, J., van Lipzig, M.M., Meerman, J.H., Belfroid, A.C., Spenkelink, A., van der Burg, B., Rijs, G.B. and Vethaak, D. (2002) Detection of estrogenic potency in wastewater and surface water with three in vitro bioassays. Environmental Toxicology and Chemistry 21(1), 1623.

Petrovic, M., Eljarrat, E., Lopez De Alda, M.J. and Barcelo, D. (2004) Endocrine disrupting compounds and other emerging contaminants in the environment: a survey on new monitoring strategies and occurrence data. Analytical and Bioanalytical Chemistry 378(3), 549-562.

Vigano, L., Benfenati, E., van Cauwenberge, A., Eidem, J.K., Erratico, C., Goksoyr, A., Kloas, W., Maggioni, S., Mandich, A. and Urbatzka, R. (2008) Estrogenicity profile and estrogenic compounds determined in river sediments by chemical analysis, ELISA and yeast assays. Chemosphere 73(7), 1078-1089.

Di Paolo, C., Ottermanns, R., Keiter, S., Ait-Aissa, S., Bluhm, K., Brack, W., Breitholtz, M., Buchinger, S., Carere, M., Chalon, C., Cousin, X., Dulio, V., Escher, B.I., Hamers, T., Hilscherova, K., Jarque, S., Jonas, A., Maillot-Marechal, E., Marneffe, Y., Nguyen, M.T., Pandard, P., Schifferli, A., Schulze, T., Seidensticker, S., Seiler, T.B., Tang, J., van der Oost, R., Vermeirssen, E., Zounkova, R., Zwart, N. and Hollert, H. (2016) Bioassay battery interlaboratory investigation of emerging contaminants in spiked water extracts - Towards the implementation of bioanalytical monitoring tools in water quality assessment and monitoring. Water Research 104, 473-484. 
Blazer, V.S., Iwanowicz, L.R., Iwanowicz, D.D., Smith, D.R., Young, J.A., Hedrick, J.D., Foster, S.W. and Reeser, S.J. (2007) Intersex (testicular oocytes) in smallmouth bass from the Potomac River and selected nearby drainages. Journal of Aquatic Animal Health 19(4), 242-253.

Iwanowicz, L.R., Blazer, V.S., Guy, C.P., Pinkney, A.E., Mullican, J.E. and Alvarez, D.A. (2009) Reproductive health of bass in the Potomac, U.S.A., drainage: part 1. Exploring the effects of proximity to wastewater treatment plant discharge. Environmental Toxicology and Chemistry 28(5), 1072-1073.

Blazer, V.S., Iwanowicz, L.R., Henderson, H., Mazik, P.M., Jenkins, J.A., Alvarez, D.A. and Young, J.A. (2012) Reproductive endocrine disruption in smallmouth bass (Micropterus dolomieu) in the Potomac River basin: spatial and temporal comparisons of biological effects. Environmental Monitoring and Assessment 184(7), 4309-4334.

Ciparis, S., Iwanowicz, L.R. and Voshell, J.R. (2012) Effects of watershed densities of animal feeding operations on nutrient concentrations and estrogenic activity in agricultural streams. Science of the Total Environment 414, 268-276.

Young, J., Iwanowicz, L., Sperry, A. and Blazer, V. (2014) A landscape-based reconnaissance survey of estrogenic activity in streams of the upper Potomac, upper James, and Shenandoah Rivers, USA. Environmental Monitoring and Assessment 186(9), 5531-5545.

Zhang, Y., Krysl, R.G., Ali, J.M., Snow, D.D., Bartelt-Hunt, S.L. and Kolok, A.S. (2015) Impact of Sediment on Agrichemical Fate and Bioavailability to Adult Female Fathead Minnows: A Field Study. Environmental Science and Technology 49(15), 9037-9047.

Hayes, T.B., Anderson, L.L., Beasley, V.R., de Solla, S.R., Iguchi, T., Ingraham, H., Kestemont, P., Kniewald, J., Kniewald, Z., Langlois, V.S., Luque, E.H., McCoy, K.A., Muñoz-de-Toro, M., Oka, T., Oliveira, C.A., Orton, F., Ruby, S., Suzawa, M., Tavera-Mendoza, L.E., Trudeau, V.L., Victor-Costa, A.B. and Willingham, E. (2011) Demasculinization and feminization of male gonads by atrazine: consistent effects across vertebrate classes. Journal of Steroid Biochemistry and Molecular Biology 127(1-2), 64-73.

Kolpin, D.W., Blazer, V.S., Gray, J.L., Focazio, M.J., Young, J.A., Alvarez, D.A., Iwanowicz, L.R., Foreman, W.T., Furlong, E.T., Speiran, G.K., Zaugg, S.D., Hubbard, L.E., Meyer, M.T., Sandstrom, M.W. and Barber, L.B. (2013) Chemical contaminants in water and sediment near fish nesting sites in the Potomac River basin: determining potential exposures to smallmouth bass (Micropterus dolomieu). Science of the Total Environment 443, 700-716.

Verdeal, K. and Ryan, D.S. (1979) Naturally-Occurring Estrogens in Plant Foodstuffs - A Review. Journal of Food Protection 42(7), 577-583.

Morito, K., Hirose, T., Kinjo, J., Hirakawa, T., Okawa, M., Nohara, T., Ogawa, S., Inoue, S., Muramatsu, M. and Masamune, Y. (2001) Interaction of phytoestrogens with estrogen receptors alpha and beta. Biological and Pharmaceutical Bulletin 24(4), 351-356.

Cappelletti, V., Miodini, P., Di Fronzo, G. and Daidone, M.G. (2006) Modulation of estrogen receptor-beta isoforms by phytoestrogens in breast cancer cells. International Journal of Oncology 28(5), 1185-1191. 
Lecomte, S., Demay, F., Ferriere, F. and Pakdel, F. (2017) Phytochemicals Targeting Estrogen Receptors: Beneficial Rather Than Adverse Effects? International Journal of Molecular Sciences 18(7), 1381-1400.

Franke, A.A., Custer, L.J., Cerna, C.M. and Narala, K.K. (1994) Quantitation of Phytoestrogens in Legumes by HPLC. Journal of Agricultural and Food Chemistry 42(9), 1905-1913.

Jarosova, B., Javurek, J., Adamovsky, O. and Hilscherova, K. (2015) Phytoestrogens and mycoestrogens in surface waters--Their sources, occurrence, and potential contribution to estrogenic activity. Environment International 81, 26-44.

Kang, J. and Price, W.E. (2009) Occurrence of phytoestrogens in municipal wastewater and surface waters. Journal of Environmental Monitoring 11(8), 1477-1483.

Kolpin, D.W., Hoerger, C.C., Meyer, M.T., Wettstein, F.E., Hubbard, L.E. and Bucheli, T.D. (2010) Phytoestrogens and Mycotoxins in Iowa Streams: An Examination of Underinvestigated Compounds in Agricultural Basins. Journal of Environment Quality 39(6), 2089.

Kuhnle, G.G.C., Dell'Aquila, C., Runswick, S.A. and Bingham, S.A. (2009) Variability of phytoestrogen content in foods from different sources. Food Chemistry 113(4), 1184-1187.

Liu, Z.H., Kanjo, Y. and Mizutani, S. (2010) A review of phytoestrogens: their occurrence and fate in the environment. Water Research 44(2), 567-577.

Setchell, K.D. and Clerici, C. (2010) Equol: history, chemistry, and formation. The Journal of Nutrition 140(7), 1355S-1362S.

Rearick, D.C., Fleischhacker, N.T., Kelly, M.M., Arnold, W.A., Novak, P.J. and Schoenfuss, H.L. (2014) Phytoestrogens in the environment, I: occurrence and exposure effects on fathead minnows. Environmental Toxicology and Chemistry 33(3), 553-559.

O’Neil, J.M., Davis, T.W., Burford, M.A. and Gobler, C.J. (2012) The rise of harmful cyanobacteria blooms: The potential roles of eutrophication and climate change. Harmful Algae 14, 313-334.

Carmichael, W.W. and Boyer, G.L. (2016) Health impacts from cyanobacteria harmful algae blooms: Implications for the North American Great Lakes. Harmful Algae 54, 194-212.

Grattan, L.M., Holobaugh, S. and Morris, J.G. (2016) Harmful algal blooms and public health. Harmful Algae 57, 2-8.

Sierosławska, A. (2010) Immunotoxic, genotoxic and carcinogenic effects of cyanotoxins. Central European Journal of Immunology 35(2), 105-110.

Oziol, L. and Bouaicha, N. (2010) First evidence of estrogenic potential of the cyanobacterial heptotoxins the nodularin-R and the microcystin-LR in cultured mammalian cells. Journal of Hazardous Materials 174(1-3), 610-615.

Štěpánková, T., Ambrožová, L., Bláha, L., Giesy, J.P. and Hilscherová, K. (2011) In vitro modulation of intracellular receptor signaling and cytotoxicity induced by extracts of cyanobacteria, complex water blooms and their fractions. Aquatic Toxicology 105(3-4), 497507. 
Sychrová, E., Štěpánková, T., Nováková, K., Bláha, L., Giesy, J.P. and Hilscherová, K. (2012) Estrogenic activity in extracts and exudates of cyanobacteria and green algae. Environment International 39(1), 134-140.

Havens, S.M., Hedman, C.J., Hemming, J.D., Mieritz, M.G., Shafer, M.M. and Schauer, J.J. (2010) Stability, preservation, and quantification of hormones and estrogenic and androgenic activities in surface water runoff. Environmental Toxicology and Chemistry 29(11), 2481-2490.

Graham, J.L., Loftin, K.A., Meyer, M.T. and Ziegler, A.C. (2010) Cyanotoxin Mixtures and Taste-and-Odor Compounds in Cyanobacterial Blooms from the Midwestern United States. Environmental Science and Technology 44(10), 7361-7368.

Loftin, K.A., Meyer, M.T., Rubio, F., Kamp, L., Humphries, E. and Whereat, E. (2008) Comparison of Two Cell Lysis Procedures for Recovery of Microcystins in Water Samples from Silver Lake in Dover, Delaware, with Microcystin Producing Cyanobacterial Accumulations, p. 9.

Laganà, A., Bacaloni, A., De Leva, I., Faberi, A., Fago, G. and Marino, A. (2004) Analytical methodologies for determining the occurrence of endocrine disrupting chemicals in sewage treatment plants and natural waters. Analytica Chimica Acta 501(1), 79-88.

Routledge, E.J. and Sumpter, J.P. (1996) Estrogenic Activity of Surficants and Some of their Degredation Products Assessed using a Recombinant Yeast Screen. Environmental Toxicology and Chemistry 15(3), 241-248.

Campas, M. and Marty, J.L. (2007) Highly sensitive amperometric immunosensors for microcystin detection in algae. Biosensors and Bioelectronics 22(6), 1034-1040.

USDA, N.A.S.S.C.D.L. (2013) Published crop-specific data layer [Online], USDA-NASS, Washington, DC.

USDA, N.A.S.S.C.D.L. (2014) Published crop-specific data layer [Online], USDA-NASS, Washington, DC.

USDA, N.A.S.S.C.D.L. (2015) Published crop-specific data layer [Online], USDA-NASS, Washington, DC.

R Core Development Team (2017) R: A language and environment for statistical computing, $R$ Foundation for Statistical Computing, Vienna, Austria.

Wu, F., Fang, Y., Li, Y., Cui, X., Zhang, R., Guo, G. and Giesy, J.P. (2014) Predicted no-effect concentration and risk assessment for 17-[beta]-estradiol in waters of China. Reviews of Environmental Contamination and Toxicology 228, 31-56.

Tan, B.L., Hawker, D.W., Muller, J.F., Leusch, F.D., Tremblay, L.A. and Chapman, H.F. (2007) Comprehensive study of endocrine disrupting compounds using grab and passive sampling at selected wastewater treatment plants in South East Queensland, Australia. Environment International 33(5), 654-669.

Raman, D.R., Williams, E.L., Layton, A.C., Burns, R.T., Easter, J.P., Daugherty, A.S., Mullen, M.D. and Sayler, G.S. (2004) Estrogen content of dairy and swine wastes. Science of the Total Environment 38(13), 3567-3573. 
Sanseverino, J., Eldridge, M.L., Layton, A.C., Easter, J.P., Yarbrough, J., Schultz, T.W. and Sayler, G.S. (2009) Screening of potentially hormonally active chemicals using bioluminescent yeast bioreporters. Toxicological Sciences 107(1), 122-134.

Chorus, I. and Bartram, J. (1999) Toxic Cyanobacteria in Water: A guide to their public health consequences, monitoring and management, World Health Organization.

Codd, G.A., Morrison, L.F. and Metcalf, J.S. (2005) Cyanobacterial toxins: risk management for health protection. Toxicology and Applied Pharmacology 203(3), 264-272.

Procházková, T., Sychrová, E., Javůrková, B., Večerková, J., Kohoutek, J., Lepsova-Skácelová, O., Bláha, L. and Hilscherová, K. (2017) Phytoestrogens and sterols in waters with cyanobacterial blooms - Analytical methods and estrogenic potencies. Chemosphere 170, 104112.

Fogg, G.E. (1975) Algal Cultures and Phytoplankton Ecology, University of Wisconsin Press. Fay, P. (1992) Oxygen relations of nitrogen fixation in cyanobacteria. Microbiological Reviews $56(2)$. 


\section{Figures}

Figure 1. Location of sampling sites throughout the Potomac River watershed.

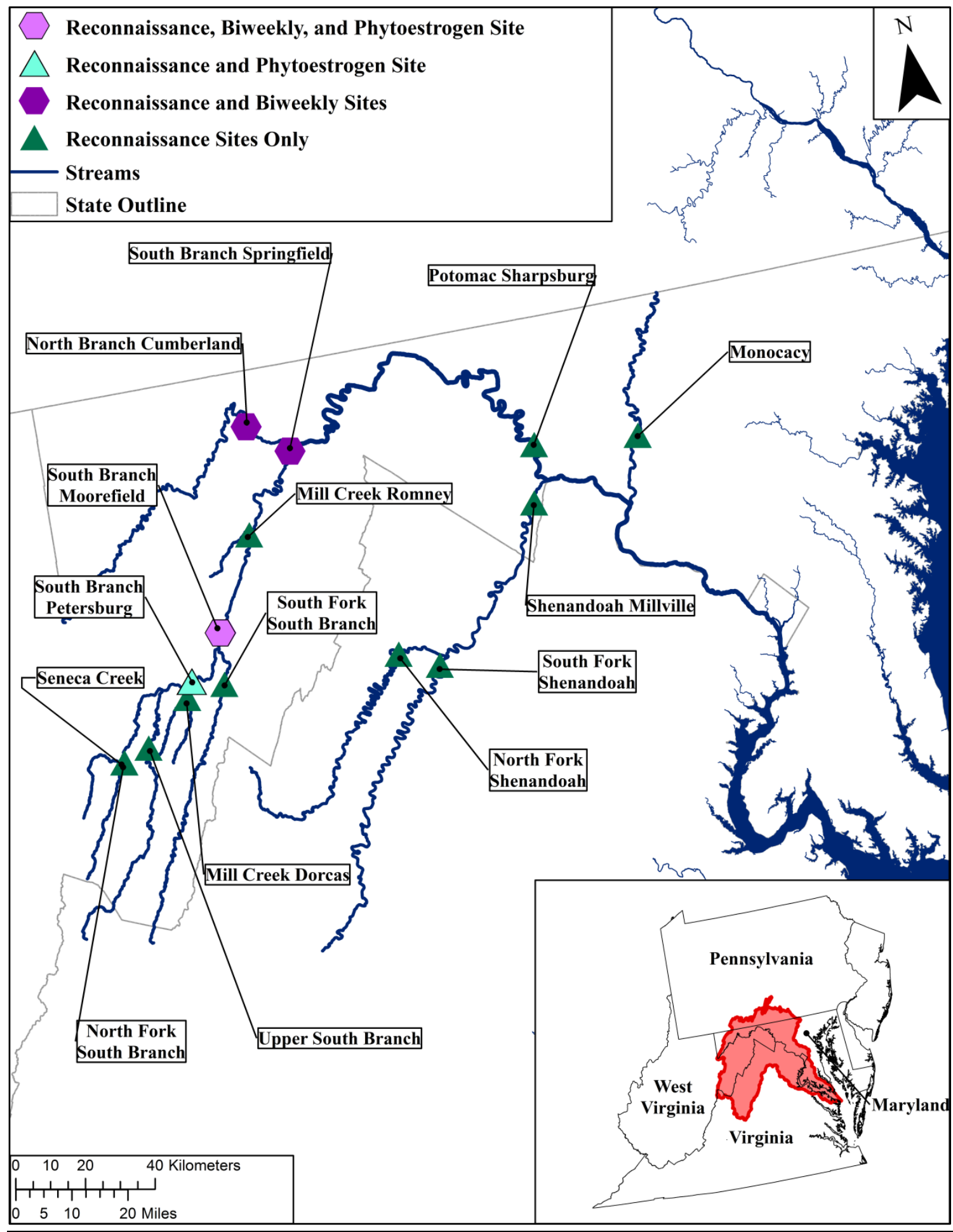


Figure 2. Temporal variability among total estrogenicity among filtered water during A) the 12 sites specific to the reconnaissance time period and both filtered and unfiltered water fractions at the three sites included in B) the biweekly sampling period. Data are pooled among all sampling locations. Error bars represent standard error.

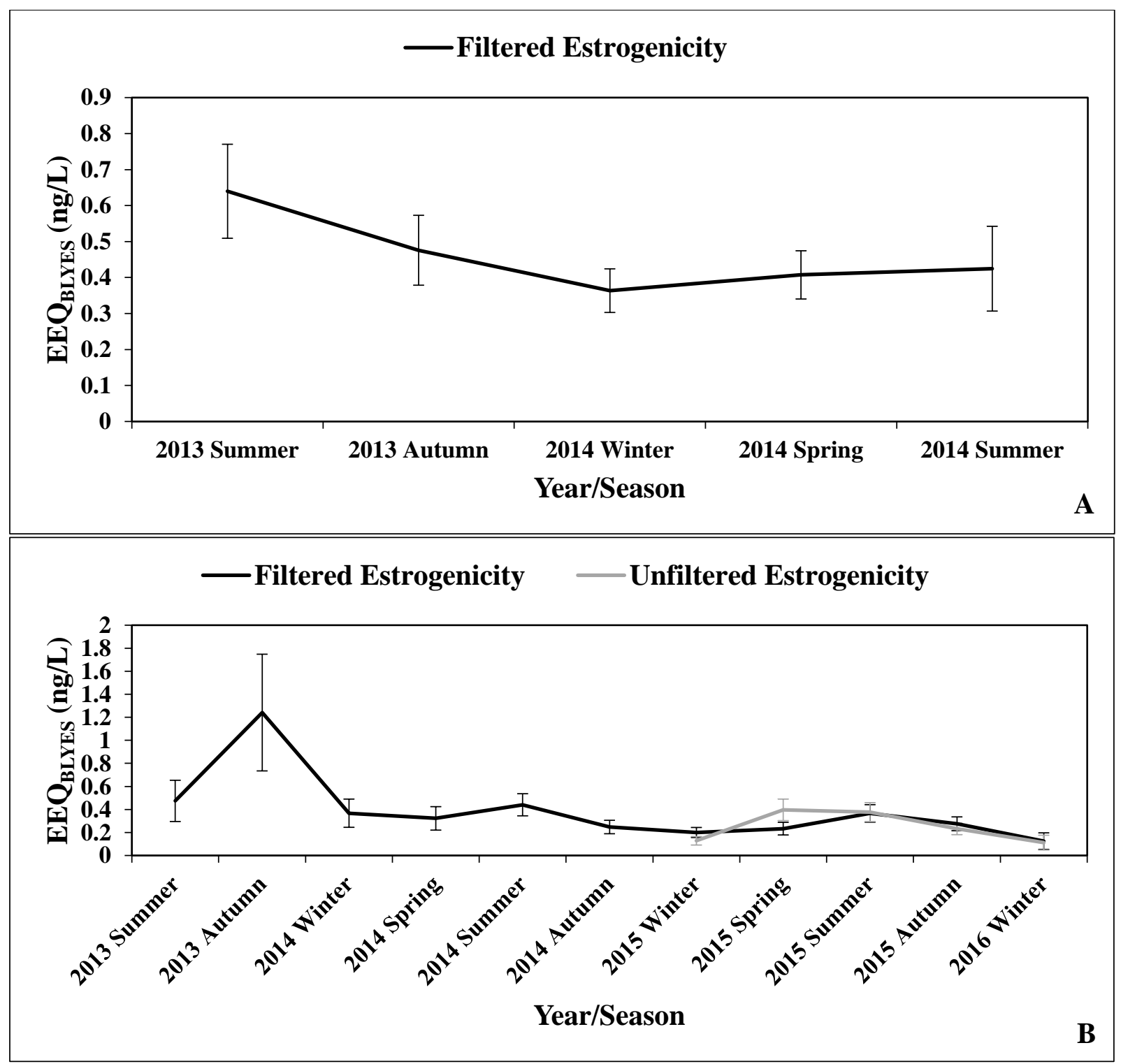


Figure 3. Temporal variability in EEQ Branch Potomac below Petersburg, WV and B) the South Branch Potomac below Moorefield, WV. The detection limits of the analysis are as follows: The LoQ for EEQвLYEs was $0.230 \mathrm{ng} / \mathrm{L}$ and 0.250 for estrone, genestein, daidzein, formonentin, and equol.
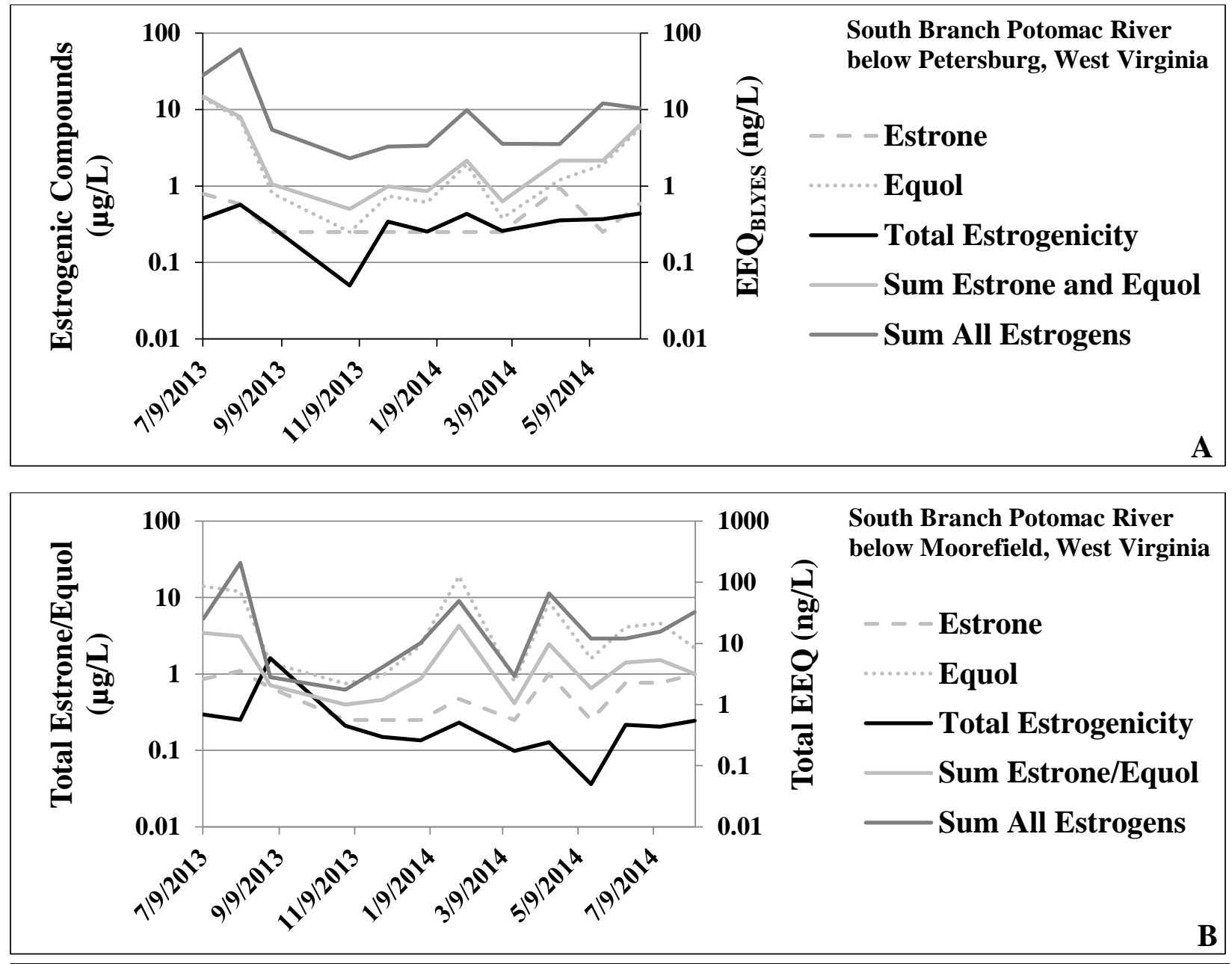
Figure 4. Temporal variability among total microcystins/nodularins among filtered and unfiltered water fractions. Data are pooled among all sampling locations. Error bars represent standard error.

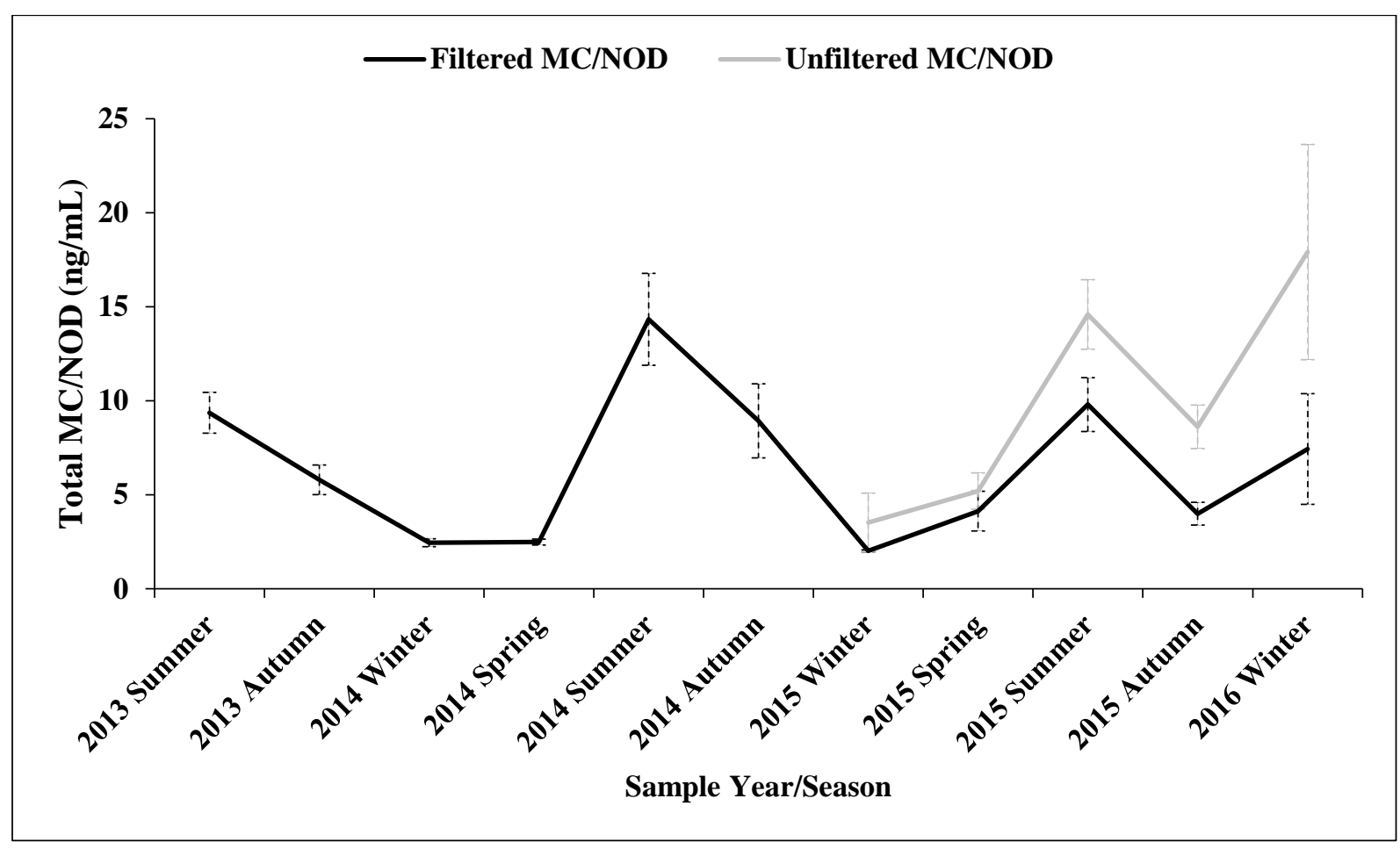




\section{Tables}

Table 1. Reclassification scheme for land cover. Original classification derived from the U.S. Department of Agriculture Cropland Data Layer. Unclassified groups presented as NA.

\begin{tabular}{|l|l|}
\hline \multicolumn{1}{|c|}{ USDA Classification Name } & $\begin{array}{l}\text { Reclassification } \\
\text { Group }\end{array}$ \\
\hline Alfalfa & Agricultural \\
\hline Almonds & Agricultural \\
\hline Apples & Agricultural \\
\hline Apricots & Agricultural \\
\hline Aquaculture & Agricultural \\
\hline Asparagus & Agricultural \\
\hline Barley & Agricultural \\
\hline Blueberries & Agricultural \\
\hline Broccoli & Agricultural \\
\hline Buckwheat & Agricultural \\
\hline Cabbage & Agricultural \\
\hline Camelina & Agricultural \\
\hline Caneberries & Agricultural \\
\hline Canola & Agricultural \\
\hline Cantaloupes & Agricultural \\
\hline Carrots & Agricultural \\
\hline Cauliflower & Agricultural \\
\hline Celery & Agricultural \\
\hline Cherries & Agricultural \\
\hline Chick Peas & Agricultural \\
\hline Christmas Trees & Agricultural \\
\hline Citrus & Agricultural \\
\hline Clover/Wildflowers & Agricultultural \\
\hline Corn & Agricultural \\
\hline Cotton & \\
\hline Cranberries & Agricultural \\
\hline Cucumbers & Agricultul \\
\hline Dbl Crop Barley/Corn & \\
\hline & Agriculal \\
\hline
\end{tabular}




\begin{tabular}{|c|c|}
\hline USDA Classification Name & $\begin{array}{l}\text { Reclassification } \\
\text { Group }\end{array}$ \\
\hline Dbl Crop Barley/Sorghum & Agricultural \\
\hline Dbl Crop Barley/Soybeans & Agricultural \\
\hline Dbl Crop Corn/Soybeans & Agricultural \\
\hline Dbl Crop Durum Wht/Sorghum & Agricultural \\
\hline Dbl Crop Lettuce/Barley & Agricultural \\
\hline Dbl Crop Lettuce/Cantaloupe & Agricultural \\
\hline Dbl Crop Lettuce/Cotton & Agricultural \\
\hline Dbl Crop Lettuce/Durum Wht & Agricultural \\
\hline Dbl Crop Oats/Corn & Agricultural \\
\hline Dbl Crop Soybeans/Cotton & Agricultural \\
\hline Dbl Crop Soybeans/Oats & Agricultural \\
\hline Dbl Crop WinWht/Corn & Agricultural \\
\hline Dbl Crop WinWht/Cotton & Agricultural \\
\hline Dbl Crop WinWht/Sorghum & Agricultural \\
\hline Dbl Crop WinWht/Soybeans & Agricultural \\
\hline Dry Beans & Agricultural \\
\hline Durum Wheat & Agricultural \\
\hline Eggplants & Agricultural \\
\hline Fallow/Idle Cropland & Agricultural \\
\hline Flaxseed & Agricultural \\
\hline Garlic & Agricultural \\
\hline Gourds & Agricultural \\
\hline Grapes & Agricultural \\
\hline Grass/Pasture & Agricultural \\
\hline Greens & Agricultural \\
\hline Herbs & Agricultural \\
\hline Honeydew Melons & Agricultural \\
\hline Hops & Agricultural \\
\hline Lentils & Agricultural \\
\hline Lettuce & Agricultural \\
\hline Millet & Agricultural \\
\hline Mint & Agricultural \\
\hline Misc Vegs \& Fruits & Agricultural \\
\hline Mustard & Agricultural \\
\hline
\end{tabular}




\begin{tabular}{|l|l|}
\hline USDA Classification Name & $\begin{array}{l}\text { Reclassification } \\
\text { Group }\end{array}$ \\
\hline Nectarines & Agricultural \\
\hline Oats & Agricultural \\
\hline Olives & Agricultural \\
\hline Onions & Agricultural \\
\hline Oranges & Agricultural \\
\hline Other Crops & Agricultural \\
\hline Other Hay/Non Alfalfa & Agricultural \\
\hline Other Small Grains & Agricultural \\
\hline Other Tree Crops & Agricultural \\
\hline Peaches & Agricultural \\
\hline Peanuts & Agricultural \\
\hline Pears & Agricultural \\
\hline Peas & Agricultural \\
\hline Pecans & Agricultural \\
\hline Peppers & Agricultural \\
\hline Pistachios & Agricultural \\
\hline Plums & Agricultural \\
\hline Pomegranates & Agricultural \\
\hline Pop or Orn Corn & Agricultural \\
\hline Potatoes & Agricultural \\
\hline Prunes & Agricultural \\
\hline Pumpkins & Agricultural \\
\hline Radishes & Agricultural \\
\hline Rape Seed & Agricultural \\
\hline Rice & Agricultural \\
\hline Rye & Agricultural \\
\hline Safflower & \\
\hline Sod/Grass Seed & Agrial \\
\hline Sorghum & Agbeans \\
\hline Speltz & Agheat \\
\hline Spring & Agries \\
\hline Squal
\end{tabular}




\begin{tabular}{|c|c|}
\hline USDA Classification Name & $\begin{array}{l}\text { Reclassification } \\
\text { Group }\end{array}$ \\
\hline Sugarbeets & Agricultural \\
\hline Sugarcane & Agricultural \\
\hline Sunflower & Agricultural \\
\hline Sweet Corn & Agricultural \\
\hline Sweet Potatoes & Agricultural \\
\hline Switchgrass & Agricultural \\
\hline Tobacco & Agricultural \\
\hline Tomatoes & Agricultural \\
\hline Triticale & Agricultural \\
\hline Turnips & Agricultural \\
\hline Vetch & Agricultural \\
\hline Walnuts & Agricultural \\
\hline Water & Agricultural \\
\hline Watermelons & Agricultural \\
\hline Winter Wheat & Agricultural \\
\hline Barren & Developed \\
\hline Developed & Developed \\
\hline Developed/High Intensity & Developed \\
\hline Developed/Low Intensity & Developed \\
\hline Developed/Med Intensity & Developed \\
\hline Developed/Open Space & Developed \\
\hline Deciduous Forest & Forested \\
\hline Evergreen Forest & Forested \\
\hline Forest & Forested \\
\hline Mixed Forest & Forested \\
\hline Shrubland & Forested \\
\hline Background & NA \\
\hline Clouds/No Data & NA \\
\hline NA & NA \\
\hline Nonag/Undefined & NA \\
\hline Perennial Ice/Snow & NA \\
\hline Open Water & Open Water \\
\hline Herbaceous Wetlands & Wetlands \\
\hline Wetlands & Wetlands \\
\hline
\end{tabular}




\begin{tabular}{|c|l|}
\hline USDA Classification Name & $\begin{array}{l}\text { Reclassification } \\
\text { Group }\end{array}$ \\
\hline Woody Wetlands & Wetlands \\
\hline
\end{tabular}


Table 2. Summary of EEQBLYES and total microcystins/nodularins in filtered water samples during the reconnaissance and biweekly sampling sites. $\mathrm{r}^{2}$ is only represented in sites with significantly correlated association between MC/NOD and EEQBLYES. SE represents standard error.

\begin{tabular}{|c|c|c|c|c|c|c|}
\hline $\begin{array}{l}\text { Stream } \\
\text { Name }\end{array}$ & $\begin{array}{c}\text { Sampling } \\
\text { Season/Year }\end{array}$ & $\begin{array}{c}\text { Filtered } \\
\text { EEQbLYES } \\
\text { (ng/L) }\end{array}$ & $\begin{array}{l}\text { Filtered } \\
\text { EEQbLYES } \\
\text { SE }\end{array}$ & $\begin{array}{c}\text { Filtered } \\
\text { Total } \\
\text { Microcystins } \\
(\mathbf{n g} / \mathbf{m L}) \\
\end{array}$ & $\begin{array}{l}\text { Filtered Total } \\
\text { Microcystins SE }\end{array}$ & $\begin{array}{l}\text { Association among Total } \\
\text { Filtered MC/NOD and } \\
\left.\text { EEQbLYEs (p-value, } \mathbf{r}^{2}\right)\end{array}$ \\
\hline \multirow{5}{*}{$\begin{array}{l}\text { Monocacy } \\
\text { River near } \\
\text { Mouth near } \\
\text { Frederick, } \\
\text { Maryland }\end{array}$} & 2013 Summer & 0.174 & 0.124 & 5.39 & 2.26 & \multirow{5}{*}{0.904} \\
\hline & 2013 Autumn & 0.359 & 0.024 & 6.19 & 1.19 & \\
\hline & 2014 Winter & 0.420 & 0.187 & 4.47 & 0.86 & \\
\hline & 2014 Spring & 0.479 & 0.080 & 3.68 & 0.94 & \\
\hline & 2014 Summer & 0.436 & NA & 2.90 & NA & \\
\hline \multirow{11}{*}{$\begin{array}{l}\text { Mainstem of } \\
\text { the North } \\
\text { Branch at } \\
\text { Cumberland, } \\
\text { Maryland }\end{array}$} & 2013 Summer & 0.352 & 0.054 & 9.18 & 2.86 & \multirow{11}{*}{$>0.001 *, 0.232$} \\
\hline & 2013 Autumn & 0.309 & 0.259 & 8.97 & 1.75 & \\
\hline & 2014 Winter & 0.296 & 0.133 & 5.04 & 1.17 & \\
\hline & 2014 Spring & 0.318 & 0.180 & 3.72 & 0.92 & \\
\hline & 2014 Summer & 0.518 & 0.069 & 6.43 & 1.95 & \\
\hline & 2014 Autumn & 0.224 & 0.110 & 6.25 & 1.59 & \\
\hline & 2015 Winter & 0.218 & 0.090 & 3.76 & 0.25 & \\
\hline & 2015 Spring & 0.162 & 0.071 & 2.93 & 0.47 & \\
\hline & 2015 Summer & 0.501 & 0.147 & 6.22 & 1.36 & \\
\hline & 2015 Autumn & 0.382 & 0.072 & 3.15 & 1.33 & \\
\hline & 2016 Winter & 0.274 & NA & 2.05 & NA & \\
\hline \multirow{5}{*}{$\begin{array}{c}\text { Mainstem of } \\
\text { the Potomac } \\
\text { River near } \\
\text { Sharpsburg, } \\
\text { Maryland }\end{array}$} & 2013 Summer & 0.289 & 0.239 & 3.15 & 0.02 & \multirow{5}{*}{0.075} \\
\hline & 2013 Autumn & 0.224 & 0.174 & 7.89 & 2.89 & \\
\hline & 2014 Winter & 0.440 & 0.040 & 5.09 & 0.24 & \\
\hline & 2014 Spring & 0.577 & 0.063 & 4.32 & 0.85 & \\
\hline & 2014 Summer & 0.050 & NA & 4.73 & $\mathrm{NA}$ & \\
\hline
\end{tabular}




\begin{tabular}{|c|c|c|c|c|c|c|}
\hline $\begin{array}{l}\text { Stream } \\
\text { Name }\end{array}$ & $\begin{array}{c}\text { Sampling } \\
\text { Season/Year }\end{array}$ & $\begin{array}{c}\text { Filtered } \\
\text { EEQ } \\
(\mathbf{n g} / \mathbf{L})\end{array}$ & $\begin{array}{l}\text { Filtered } \\
\text { EEQвLYES } \\
\text { SE }\end{array}$ & $\begin{array}{c}\text { Filtered } \\
\text { Total } \\
\text { Microcystins } \\
(\mathbf{n g} / \mathbf{m L}) \\
\end{array}$ & $\begin{array}{c}\text { Filtered Total } \\
\text { Microcystins SE }\end{array}$ & 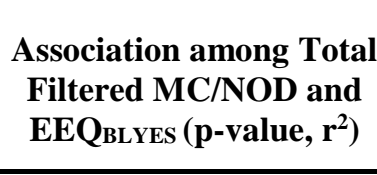 \\
\hline \multirow{5}{*}{$\begin{array}{l}\text { North Fork } \\
\text { of the South } \\
\text { Branch at } \\
\text { Seneca } \\
\text { Rocks, West } \\
\text { Virginia }\end{array}$} & 2013 Summer & 0.296 & 0.246 & 18.60 & 2.09 & \multirow{5}{*}{0.620} \\
\hline & 2013 Autumn & 0.437 & 0.128 & 9.17 & 3.53 & \\
\hline & 2014 Winter & 0.397 & 0.209 & 5.41 & 0.68 & \\
\hline & 2014 Spring & 0.417 & 0.041 & 4.47 & 0.71 & \\
\hline & 2014 Summer & 0.448 & NA & 11.21 & NA & \\
\hline \multirow{5}{*}{$\begin{array}{c}\text { South Fork } \\
\text { of the South } \\
\text { Branch near } \\
\text { Moorefield, } \\
\text { West } \\
\text { Virginia }\end{array}$} & 2013 Summer & 0.331 & 0.059 & 7.15 & 4.02 & \multirow{5}{*}{0.419} \\
\hline & 2013 Autumn & 0.651 & 0.601 & 7.17 & 2.17 & \\
\hline & 2014 Winter & 0.312 & 0.146 & 4.96 & 1.25 & \\
\hline & 2014 Spring & 0.251 & 0.108 & 2.53 & 0.22 & \\
\hline & 2014 Summer & 0.454 & NA & 5.69 & NA & \\
\hline \multirow{5}{*}{$\begin{array}{l}\text { Upper } \\
\text { Mainstem of } \\
\text { the South } \\
\text { Branch }\end{array}$} & 2013 Summer & 1.003 & 0.953 & 8.74 & 2.60 & \multirow{5}{*}{0.647} \\
\hline & 2013 Autumn & 0.180 & 0.130 & 4.70 & 0.31 & \\
\hline & 2014 Winter & 0.163 & 0.113 & 5.68 & 0.59 & \\
\hline & 2014 Spring & 0.288 & 0.146 & 4.28 & 0.82 & \\
\hline & 2014 Summer & 0.399 & NA & 3.93 & NA & \\
\hline \multirow{5}{*}{$\begin{array}{c}\text { Mainstem of } \\
\text { the South } \\
\text { Branch at } \\
\text { Petersburg, } \\
\text { West } \\
\text { Virginia }\end{array}$} & 2013 Summer & 0.474 & 0.096 & 8.42 & 5.38 & \multirow{5}{*}{0.074} \\
\hline & 2013 Autumn & 0.170 & 0.120 & 4.87 & 0.14 & \\
\hline & 2014 Winter & 0.342 & 0.052 & 5.68 & 0.59 & \\
\hline & 2014 Spring & 0.327 & 0.034 & 4.98 & 1.12 & \\
\hline & 2014 Summer & 0.475 & 0.037 & 16.28 & 3.27 & \\
\hline
\end{tabular}




\begin{tabular}{|c|c|c|c|c|c|c|}
\hline $\begin{array}{l}\text { Stream } \\
\text { Name }\end{array}$ & $\begin{array}{c}\text { Sampling } \\
\text { Season/Year }\end{array}$ & $\begin{array}{c}\text { Filtered } \\
\text { EEQвLYES } \\
\text { (ng/L) }\end{array}$ & $\begin{array}{c}\text { Filtered } \\
\text { EEQbLYES } \\
\text { SE }\end{array}$ & $\begin{array}{c}\text { Filtered } \\
\text { Total } \\
\text { Microcystins } \\
(\mathbf{n g} / \mathbf{m L}) \\
\end{array}$ & $\begin{array}{c}\text { Filtered Total } \\
\text { Microcystins SE }\end{array}$ & $\begin{array}{l}\text { Association among Total } \\
\text { Filtered MC/NOD and } \\
\left.\text { EEQbLYEs (p-value, } \mathbf{r}^{2}\right)\end{array}$ \\
\hline \multirow{11}{*}{$\begin{array}{l}\text { Mainstem of } \\
\text { the South } \\
\text { Branch near } \\
\text { Moorefield, } \\
\text { West } \\
\text { Virginia }\end{array}$} & 2013 Summer & 0.627 & 0.063 & 9.24 & 6.20 & \multirow{11}{*}{0.161} \\
\hline & 2013 Autumn & 3.099 & 2.650 & 11.45 & 4.69 & \\
\hline & 2014 Winter & 0.353 & 0.077 & 5.21 & 1.01 & \\
\hline & 2014 Spring & 0.155 & 0.061 & 3.94 & 0.48 & \\
\hline & 2014 Summer & 0.417 & 0.057 & 23.15 & 5.05 & \\
\hline & 2014 Autumn & 0.319 & 0.023 & 9.86 & 3.66 & \\
\hline & 2015 Winter & 0.229 & 0.075 & 4.56 & 0.56 & \\
\hline & 2015 Spring & 0.381 & 0.331 & 2.66 & 0.32 & \\
\hline & 2015 Summer & 0.330 & 0.048 & 9.67 & 2.11 & \\
\hline & 2015 Autumn & 0.177 & 0.047 & 4.05 & 1.28 & \\
\hline & 2016 Winter & 0.050 & NA & 8.06 & NA & \\
\hline \multirow{11}{*}{$\begin{array}{l}\text { Mainstem of } \\
\text { the South } \\
\text { Branch near } \\
\text { Mouth near } \\
\text { Springfield, } \\
\text { West } \\
\text { Virginia }\end{array}$} & 2013 Summer & 0.505 & 0.082 & 12.34 & 7.92 & \multirow{11}{*}{$0.035^{*}, 0.070$} \\
\hline & 2013 Autumn & 0.316 & 0.035 & 10.45 & 5.27 & \\
\hline & 2014 Winter & 0.453 & 0.046 & 5.97 & 0.63 & \\
\hline & 2014 Spring & 0.549 & 0.089 & 4.65 & 1.32 & \\
\hline & 2014 Summer & 0.382 & 0.071 & 28.04 & 5.52 & \\
\hline & 2014 Autumn & 0.199 & 0.067 & 11.43 & 4.06 & \\
\hline & 2015 Winter & 0.152 & 0.049 & 3.61 & 0.17 & \\
\hline & 2015 Spring & 0.157 & 0.068 & 6.60 & 2.91 & \\
\hline & 2015 Summer & 0.274 & 0.050 & 14.65 & 3.31 & \\
\hline & 2015 Autumn & 0.266 & 0.102 & 4.30 & 0.70 & \\
\hline & 2016 Winter & 0.050 & NA & 12.19 & NA & \\
\hline \multirow{5}{*}{$\begin{array}{c}\text { Mill Creek } \\
\text { near Dorcas, } \\
\text { West } \\
\text { Virginia }\end{array}$} & 2013 Summer & 0.050 & 0.000 & 5.62 & 2.49 & \multirow{5}{*}{0.440} \\
\hline & 2013 Autumn & 0.317 & 0.031 & 5.67 & 2.87 & \\
\hline & 2014 Winter & 0.840 & 0.610 & 5.77 & 0.52 & \\
\hline & 2014 Spring & 0.532 & 0.057 & 4.67 & 0.70 & \\
\hline & 2014 Summer & 0.050 & NA & 4.16 & NA & \\
\hline
\end{tabular}




\begin{tabular}{|c|c|c|c|c|c|c|}
\hline $\begin{array}{l}\text { Stream } \\
\text { Name }\end{array}$ & $\begin{array}{l}\text { Sampling } \\
\text { Season/Year }\end{array}$ & $\begin{array}{c}\text { Filtered } \\
\text { EEQbLYES } \\
\text { (ng/L) }\end{array}$ & $\begin{array}{l}\text { Filtered } \\
\text { EEQbLYES } \\
\text { SE }\end{array}$ & $\begin{array}{c}\text { Filtered } \\
\text { Total } \\
\text { Microcystins } \\
(\mathbf{n g} / \mathbf{m L}) \\
\end{array}$ & $\begin{array}{c}\text { Filtered Total } \\
\text { Microcystins SE }\end{array}$ & $\begin{array}{l}\text { Association among Total } \\
\text { Filtered MC/NOD and } \\
\left.\text { EEQBLYEs (p-value, } \mathbf{r}^{2}\right)\end{array}$ \\
\hline \multirow{5}{*}{$\begin{array}{c}\text { Mill Creek } \\
\text { near } \\
\text { Romney, } \\
\text { West } \\
\text { Virginia }\end{array}$} & 2013 Summer & 3.088 & 2.476 & 12.21 & 5.52 & \multirow{5}{*}{0.312} \\
\hline & 2013 Autumn & 1.058 & 0.752 & 3.62 & 0.58 & \\
\hline & 2014 Winter & 0.359 & 0.155 & 5.77 & 0.52 & \\
\hline & 2014 Spring & 0.354 & 0.036 & 3.72 & 0.92 & \\
\hline & 2014 Summer & 0.696 & NA & 39.46 & NA & \\
\hline \multirow{5}{*}{$\begin{array}{l}\text { Seneca } \\
\text { Creek near } \\
\text { Seneca } \\
\text { Rocks, West } \\
\text { Virginia }\end{array}$} & 2013 Summer & 0.490 & 0.036 & 10.77 & 1.30 & \multirow{5}{*}{0.770} \\
\hline & 2013 Autumn & 0.227 & 0.177 & 4.53 & 1.49 & \\
\hline & 2014 Winter & 0.279 & 0.121 & 5.57 & 1.52 & \\
\hline & 2014 Spring & 0.423 & 0.038 & 2.69 & 0.10 & \\
\hline & 2014 Summer & 0.525 & NA & 5.26 & NA & \\
\hline \multirow{5}{*}{$\begin{array}{l}\text { North Fork } \\
\text { of the } \\
\text { Shenandoah } \\
\text { River at } \\
\text { Strasburg, } \\
\text { Virginia }\end{array}$} & 2013 Summer & 0.398 & 0.080 & 6.06 & 2.93 & \multirow{5}{*}{0.907} \\
\hline & 2013 Autumn & 0.655 & 0.176 & 8.14 & 3.14 & \\
\hline & 2014 Winter & 0.265 & 0.131 & 6.36 & 0.40 & \\
\hline & 2014 Spring & 0.246 & 0.196 & 3.11 & 0.32 & \\
\hline & 2014 Summer & 0.438 & NA & 3.90 & NA & \\
\hline \multirow{5}{*}{$\begin{array}{l}\text { South Fork } \\
\text { of the } \\
\text { Shenandoah } \\
\text { River at } \\
\text { Front Royal, } \\
\text { Virginia }\end{array}$} & 2013 Summer & 0.606 & 0.046 & 3.28 & 1.75 & \multirow{5}{*}{0.055} \\
\hline & 2013 Autumn & 0.736 & 0.032 & 5.28 & 0.76 & \\
\hline & 2014 Winter & 0.307 & 0.142 & 5.36 & 1.40 & \\
\hline & 2014 Spring & 0.452 & 0.093 & 2.72 & 0.10 & \\
\hline & 2014 Summer & 0.551 & NA & 2.56 & NA & \\
\hline \multirow{5}{*}{$\begin{array}{c}\text { Shenandoah } \\
\text { River at } \\
\text { Millville, } \\
\text { West } \\
\text { Virginia }\end{array}$} & 2013 Summer & 0.478 & 0.003 & 7.74 & 0.94 & \multirow{5}{*}{0.205} \\
\hline & 2013 Autumn & 0.696 & 0.133 & 4.79 & 0.21 & \\
\hline & 2014 Winter & 0.239 & 0.111 & 5.95 & 0.21 & \\
\hline & 2014 Spring & 0.519 & 0.038 & 2.55 & 0.08 & \\
\hline & 2014 Summer & 0.522 & NA & 6.76 & NA & \\
\hline
\end{tabular}


Table 3. Summary of EEQ during the reconnaissance and biweekly sampling sites. SE represents standard error.

\begin{tabular}{|c|c|c|c|c|c|c|}
\hline Stream Name & $\begin{array}{c}\text { Sampling } \\
\text { Season/Year }\end{array}$ & $\begin{array}{c}\text { Unfiltered } \\
\text { EEQBLYES } \\
\text { (ng/L) }\end{array}$ & $\begin{array}{c}\text { Unfiltered } \\
\text { EEQBLYES } \\
\text { SE }\end{array}$ & $\begin{array}{c}\text { Unfiltered } \\
\text { Total } \\
\text { Microcystins } \\
(\text { ng/mL })\end{array}$ & $\begin{array}{c}\text { Unfiltered } \\
\text { Total } \\
\text { Microcystins } \\
\text { SE }\end{array}$ & $\begin{array}{l}\text { Association } \\
\text { among Total } \\
\text { Unfiltered } \\
\text { MC/NOD and } \\
\text { EEQBLYES (p- } \\
\text { value) }\end{array}$ \\
\hline \multirow{5}{*}{$\begin{array}{l}\text { Mainstem of the } \\
\text { North Branch at } \\
\text { Cumberland, } \\
\text { Maryland }\end{array}$} & 2015 Winter & 0.102 & 0.052 & 3.41 & 0.53 & \multirow{5}{*}{0.086} \\
\hline & 2015 Spring & 0.494 & 0.240 & 3.10 & 0.90 & \\
\hline & 2015 Summer & 0.531 & 0.132 & 7.47 & 1.92 & \\
\hline & 2015 Autumn & 0.353 & 0.087 & 8.45 & 1.86 & \\
\hline & 2016 Winter & 0.235 & NA & 6.47 & NA & \\
\hline \multirow{5}{*}{$\begin{array}{c}\text { Mainstem of the } \\
\text { South Branch } \\
\text { near } \\
\text { Moorefield, } \\
\text { West Virginia }\end{array}$} & 2015 Winter & 0.050 & 0.000 & 5.67 & 1.33 & \multirow{5}{*}{0.306} \\
\hline & 2015 Spring & 0.345 & 0.152 & 4.32 & 1.32 & \\
\hline & 2015 Summer & 0.302 & 0.049 & 13.93 & 2.37 & \\
\hline & 2015 Autumn & 0.161 & 0.057 & 9.32 & 2.74 & \\
\hline & 2016 Winter & 0.050 & NA & 23.24 & NA & \\
\hline \multirow{5}{*}{$\begin{array}{l}\text { Mainstem of the } \\
\text { South Branch } \\
\text { near Mouth } \\
\text { near } \\
\text { Springfield, } \\
\text { West Virginia }\end{array}$} & 2015 Winter & 0.231 & 0.107 & 6.16 & 2.48 & \multirow{5}{*}{0.730} \\
\hline & 2015 Spring & 0.350 & 0.104 & 7.57 & 2.37 & \\
\hline & 2015 Summer & 0.298 & 0.060 & 22.37 & 2.51 & \\
\hline & 2015 Autumn & 0.179 & 0.061 & 8.00 & 1.57 & \\
\hline & 2016 Winter & 0.050 & NA & 24.01 & NA & \\
\hline
\end{tabular}


Table 4. Spatial summary for each sample site. Wastewater treatment facilities presented as

WWTP.

\begin{tabular}{|c|c|c|c|c|c|}
\hline Watershed & Stream Name & Latitude & Longitude & $\begin{array}{c}\text { Basin Area } \\
\left(\mathbf{k m}^{2}\right)\end{array}$ & $\begin{array}{c}\text { Total } \\
\text { WWTP's }\end{array}$ \\
\hline Monocacy & $\begin{array}{l}\text { Monocacy River near Frederick, } \\
\text { Maryland }\end{array}$ & 39.387788 & -77.379848 & 2119.41 & 24 \\
\hline $\begin{array}{l}\text { North Branch } \\
\text { Potomac }\end{array}$ & $\begin{array}{l}\text { North Branch Potomac at Cumberland, } \\
\text { Maryland }\end{array}$ & 39.586902 & -78.737522 & 2544.65 & 28 \\
\hline \multirow{9}{*}{$\begin{array}{l}\text { South Branch } \\
\text { Potomac }\end{array}$} & $\begin{array}{l}\text { North Fork South Branch Potomac } \\
\text { near Petersburg, West Virginia }\end{array}$ & 38.833894 & -79.371852 & 443.07 & 0 \\
\hline & $\begin{array}{l}\text { South Fork South Branch Potomac } \\
\text { near Moorefield, West Virginia }\end{array}$ & 38.979448 & -78.977210 & 673.08 & 1 \\
\hline & $\begin{array}{l}\text { South Branch Potomac below } \\
\text { Petersburg, West Virginia }\end{array}$ & 38.999172 & -79.086226 & 2207.83 & 4 \\
\hline & $\begin{array}{l}\text { South Branch Potomac below } \\
\text { Moorefield, West Virginia }\end{array}$ & 39.104069 & -78.957706 & 3115.99 & 5 \\
\hline & $\begin{array}{l}\text { South Branch Potomac below } \\
\text { Franklin, West Virginia }\end{array}$ & 38.858884 & -79.279073 & 778.01 & 2 \\
\hline & $\begin{array}{l}\text { South Branch Potomac near } \\
\text { Springfield, West Virginia }\end{array}$ & 39.509346 & -78.600141 & 3822.54 & 7 \\
\hline & $\begin{array}{l}\text { Seneca Creek at Seneca Rocks, West } \\
\text { Virginia }\end{array}$ & 38.834233 & -79.371759 & 176.77 & 0 \\
\hline & $\begin{array}{l}\text { Mill Creek (Grant County, West } \\
\text { Virginia) }\end{array}$ & 38.961819 & -79.114410 & 122.57 & 0 \\
\hline & $\begin{array}{l}\text { Mill Creek (Hampshire County, West } \\
\text { Virginia) }\end{array}$ & 39.327161 & -78.796280 & 120.80 & 0 \\
\hline $\begin{array}{l}\text { Mainstem } \\
\text { Potomac }\end{array}$ & $\begin{array}{l}\text { Potomac Mainstem Below Antietam } \\
\text { Creek near Sharpsburg, Maryland }\end{array}$ & 39.414305 & -77.746319 & 16229.73 & 87 \\
\hline \multirow{3}{*}{$\begin{array}{l}\text { Shenandoah } \\
\text { River }\end{array}$} & $\begin{array}{l}\text { North Fork Shenandoah River at } \\
\text { Strasburg, Virginia }\end{array}$ & 38.974316 & -78.355075 & 1981.05 & 7 \\
\hline & $\begin{array}{l}\text { South Fork Shenandoah River at Front } \\
\text { Royal, Virginia }\end{array}$ & 38.929167 & -78.219768 & 4230.90 & 23 \\
\hline & $\begin{array}{l}\text { Shenandoah River Mainstem near } \\
\text { Millville, West Virginia }\end{array}$ & 39.274741 & -77.785619 & 7852.31 & 37 \\
\hline
\end{tabular}


Table 5. Land cover summary for each sample site. These percentages represent the full watershed upstream from each sampling site. The percentage of wetland/open water are excluded.

\begin{tabular}{|c|c|c|c|c|c|c|c|c|c|}
\hline & \multicolumn{3}{|c|}{ Agricultural } & \multicolumn{3}{|c|}{ Developed } & \multicolumn{3}{|c|}{ Forested } \\
\hline Stream Name & 2013 & 2014 & 2015 & 2013 & 2014 & 2015 & 2013 & 2014 & 2015 \\
\hline $\begin{array}{l}\text { Monocacy River near } \\
\text { Frederick, Maryland }\end{array}$ & $53.05 \%$ & $52.87 \%$ & $49.68 \%$ & $12.26 \%$ & $13.00 \%$ & $12.93 \%$ & $34.09 \%$ & $33.25 \%$ & $36.43 \%$ \\
\hline $\begin{array}{l}\text { North Branch Potomac at } \\
\text { Cumberland, Maryland }\end{array}$ & $10.64 \%$ & $10.50 \%$ & $8.18 \%$ & $7.83 \%$ & $7.96 \%$ & $8.45 \%$ & $80.76 \%$ & $80.52 \%$ & $82.41 \%$ \\
\hline $\begin{array}{l}\text { North Fork South Branch } \\
\text { Potomac near Petersburg, West } \\
\text { Virginia }\end{array}$ & $10.19 \%$ & $11.63 \%$ & $8.62 \%$ & $3.88 \%$ & $3.85 \%$ & $3.79 \%$ & $85.85 \%$ & $84.47 \%$ & $87.54 \%$ \\
\hline $\begin{array}{l}\text { South Fork South Branch } \\
\text { Potomac near Moorefield, West } \\
\text { Virginia }\end{array}$ & $8.27 \%$ & $8.77 \%$ & $7.14 \%$ & $3.43 \%$ & $3.42 \%$ & $3.46 \%$ & $88.12 \%$ & $87.59 \%$ & $89.15 \%$ \\
\hline $\begin{array}{l}\text { South Branch Potomac below } \\
\text { Petersburg, West Virginia }\end{array}$ & $16.29 \%$ & $17.54 \%$ & $14.24 \%$ & $3.68 \%$ & $3.68 \%$ & $3.68 \%$ & $79.89 \%$ & $78.61 \%$ & $81.92 \%$ \\
\hline $\begin{array}{l}\text { South Branch Potomac below } \\
\text { Moorefield, West Virginia }\end{array}$ & $15.30 \%$ & $16.42 \%$ & $13.43 \%$ & $3.82 \%$ & $3.82 \%$ & $3.83 \%$ & $80.70 \%$ & $79.54 \%$ & $82.50 \%$ \\
\hline $\begin{array}{l}\text { South Branch Potomac below } \\
\text { Franklin, West Virginia }\end{array}$ & $20.89 \%$ & $21.98 \%$ & $18.76 \%$ & $4.23 \%$ & $4.13 \%$ & $4.15 \%$ & $74.81 \%$ & $73.82 \%$ & $77.01 \%$ \\
\hline $\begin{array}{l}\text { South Branch Potomac near } \\
\text { Springfield, West Virginia }\end{array}$ & $15.28 \%$ & $16.32 \%$ & $13.39 \%$ & $3.77 \%$ & $3.79 \%$ & $3.82 \%$ & $80.66 \%$ & $79.54 \%$ & $82.42 \%$ \\
\hline $\begin{array}{l}\text { Seneca Creek at Seneca Rocks, } \\
\text { West Virginia }\end{array}$ & $5.69 \%$ & $6.59 \%$ & $4.31 \%$ & $2.46 \%$ & $2.55 \%$ & $2.46 \%$ & $91.83 \%$ & $90.82 \%$ & $93.21 \%$ \\
\hline $\begin{array}{l}\text { Mill Creek (Grant County, } \\
\text { West Virginia) }\end{array}$ & $16.96 \%$ & $18.14 \%$ & $14.09 \%$ & $3.77 \%$ & $3.87 \%$ & $3.81 \%$ & $79.24 \%$ & $77.92 \%$ & $82.07 \%$ \\
\hline $\begin{array}{l}\text { Mill Creek (Hampshire County, } \\
\text { West Virginia) }\end{array}$ & $12.00 \%$ & $12.68 \%$ & $9.44 \%$ & $4.33 \%$ & $4.27 \%$ & $4.33 \%$ & $83.66 \%$ & $83.00 \%$ & $86.16 \%$ \\
\hline $\begin{array}{l}\text { Potomac Mainstem Below } \\
\text { Antietam Creek near } \\
\text { Sharpsburg, Maryland }\end{array}$ & $22.62 \%$ & $22.68 \%$ & $20.58 \%$ & $7.36 \%$ & $7.67 \%$ & $7.73 \%$ & $69.54 \%$ & $68.99 \%$ & $71.04 \%$ \\
\hline $\begin{array}{l}\text { North Fork Shenandoah River } \\
\text { at Strasburg, Virginia }\end{array}$ & $34.90 \%$ & $35.38 \%$ & $33.78 \%$ & $6.29 \%$ & $6.29 \%$ & $6.30 \%$ & $58.60 \%$ & $57.96 \%$ & $59.51 \%$ \\
\hline $\begin{array}{l}\text { South Fork Shenandoah River } \\
\text { at Front Royal, Virginia }\end{array}$ & $33.99 \%$ & $34.60 \%$ & $33.13 \%$ & $10.26 \%$ & $10.30 \%$ & $10.32 \%$ & $55.39 \%$ & $54.57 \%$ & $55.99 \%$ \\
\hline $\begin{array}{l}\text { Shenandoah River Mainstem } \\
\text { near Millville, West Virginia }\end{array}$ & $34.28 \%$ & $34.71 \%$ & $33.11 \%$ & $8.95 \%$ & $9.00 \%$ & $9.02 \%$ & $56.37 \%$ & $55.71 \%$ & $57.27 \%$ \\
\hline
\end{tabular}


Table 6. Land cover summary for each sample site. These percentages represent the land cover/land use within a 30 meter buffer on either side of streams within each watershed upstream from each sampling site. The percentage of wetland/open water are excluded.

\begin{tabular}{|c|c|c|c|c|c|c|c|c|c|}
\hline & \multicolumn{3}{|c|}{ Agricultural } & \multicolumn{3}{|c|}{ Developed } & \multicolumn{3}{|c|}{ Forested } \\
\hline Stream Name & 2013 & 2014 & 2015 & 2013 & 2014 & 2015 & 2013 & 2014 & 2015 \\
\hline $\begin{array}{l}\text { Monocacy River near } \\
\text { Frederick, Maryland }\end{array}$ & $39.23 \%$ & $38.90 \%$ & $33.79 \%$ & $11.06 \%$ & $11.49 \%$ & $11.50 \%$ & $47.17 \%$ & $45.68 \%$ & $50.71 \%$ \\
\hline $\begin{array}{l}\text { North Branch Potomac at } \\
\text { Cumberland, Maryland }\end{array}$ & $7.91 \%$ & $7.32 \%$ & $5.54 \%$ & $10.90 \%$ & $11.01 \%$ & $11.02 \%$ & $77.96 \%$ & $76.93 \%$ & $78.57 \%$ \\
\hline $\begin{array}{l}\text { North Fork South Branch } \\
\text { Potomac near Petersburg, West } \\
\text { Virginia }\end{array}$ & $15.42 \%$ & $17.42 \%$ & $12.15 \%$ & $8.02 \%$ & $8.02 \%$ & $7.94 \%$ & $76.19 \%$ & $74.38 \%$ & $79.70 \%$ \\
\hline $\begin{array}{l}\text { South Fork South Branch } \\
\text { Potomac near Moorefield, West } \\
\text { Virginia }\end{array}$ & $10.18 \%$ & $10.46 \%$ & $7.71 \%$ & $6.58 \%$ & $6.52 \%$ & $6.60 \%$ & $82.56 \%$ & $82.23 \%$ & $84.83 \%$ \\
\hline $\begin{array}{l}\text { South Branch Potomac below } \\
\text { Petersburg, West Virginia }\end{array}$ & $24.44 \%$ & $25.50 \%$ & $20.07 \%$ & $8.04 \%$ & $8.01 \%$ & $8.02 \%$ & $66.89 \%$ & $65.88 \%$ & $71.19 \%$ \\
\hline $\begin{array}{l}\text { South Branch Potomac below } \\
\text { Moorefield, West Virginia }\end{array}$ & $21.57 \%$ & $22.49 \%$ & $17.60 \%$ & $7.64 \%$ & $7.59 \%$ & $7.63 \%$ & $69.96 \%$ & $69.04 \%$ & $73.72 \%$ \\
\hline $\begin{array}{l}\text { South Branch Potomac below } \\
\text { Franklin, West Virginia }\end{array}$ & $33.46 \%$ & $33.40 \%$ & $28.48 \%$ & $9.65 \%$ & $9.49 \%$ & $9.50 \%$ & $56.64 \%$ & $56.82 \%$ & $61.74 \%$ \\
\hline $\begin{array}{l}\text { South Branch Potomac near } \\
\text { Springfield, West Virginia }\end{array}$ & $21.09 \%$ & $21.87 \%$ & $17.08 \%$ & $7.38 \%$ & $7.35 \%$ & $7.38 \%$ & $69.93 \%$ & $69.06 \%$ & $73.62 \%$ \\
\hline $\begin{array}{l}\text { Seneca Creek at Seneca Rocks, } \\
\text { West Virginia }\end{array}$ & $3.36 \%$ & $3.95 \%$ & $2.51 \%$ & $8.02 \%$ & $8.05 \%$ & $8.08 \%$ & $88.53 \%$ & $87.94 \%$ & $89.38 \%$ \\
\hline $\begin{array}{l}\text { Mill Creek (Grant County, } \\
\text { West Virginia) }\end{array}$ & $18.95 \%$ & $19.61 \%$ & $13.76 \%$ & $7.30 \%$ & $7.10 \%$ & $7.24 \%$ & $73.73 \%$ & $73.22 \%$ & $78.96 \%$ \\
\hline $\begin{array}{l}\text { Mill Creek (Hampshire County, } \\
\text { West Virginia) }\end{array}$ & $16.66 \%$ & $15.85 \%$ & $10.87 \%$ & $10.41 \%$ & $10.43 \%$ & $10.40 \%$ & $72.91 \%$ & $73.69 \%$ & $78.60 \%$ \\
\hline $\begin{array}{l}\text { Potomac Mainstem Below } \\
\text { Antietam Creek near } \\
\text { Sharpsburg, Maryland }\end{array}$ & $19.65 \%$ & $19.66 \%$ & $16.69 \%$ & $8.71 \%$ & $8.84 \%$ & $8.86 \%$ & $69.36 \%$ & $68.56 \%$ & $71.42 \%$ \\
\hline $\begin{array}{l}\text { North Fork Shenandoah River } \\
\text { at Strasburg, Virginia }\end{array}$ & $32.06 \%$ & $32.56 \%$ & $30.04 \%$ & $7.15 \%$ & $7.12 \%$ & $7.11 \%$ & $59.31 \%$ & $58.05 \%$ & $60.44 \%$ \\
\hline $\begin{array}{l}\text { South Fork Shenandoah River } \\
\text { at Front Royal, Virginia }\end{array}$ & $31.58 \%$ & $32.37 \%$ & $30.15 \%$ & $10.70 \%$ & $10.62 \%$ & $10.69 \%$ & $55.27 \%$ & $53.99 \%$ & $56.01 \%$ \\
\hline $\begin{array}{l}\text { Shenandoah River Mainstem } \\
\text { near Millville, West Virginia }\end{array}$ & $30.02 \%$ & $30.57 \%$ & $28.24 \%$ & $9.25 \%$ & $9.22 \%$ & $9.25 \%$ & $58.10 \%$ & $56.98 \%$ & $59.16 \%$ \\
\hline
\end{tabular}




\title{
Chapter Five. Evaluation of possible interference as reported by the yeast strain Saccharomyces cerevisiae BLYR
}

\begin{abstract}
Estrogenic endocrine disrupting compounds (EEDCs) are a class of chemicals which have been shown to dysregulate reproductive pathways. The identification of these compounds is critical for understanding the biological effects potentially caused by EEDCs. The yeast strain Saccharomyces cerevisiae BLYR incorporates a constitutively expressed reporter and is designed to be a measure of toxicity; however, we reference output as interference. BLYR output was quantified among various concentrations of two solvents, methanol (MeOH) and dimethyl sulfoxide (DMSO), as well as $17 \beta$-estradiol and extracts from both environmental water and periphyton samples. Challenged $S$. cerevisiae cells were also evaluated using flow cytometry to determine whether a decrease in BLYR output was a result of cell mortality. Temporal and spatial variability in BLYR output was assessed at select sites in the Potomac River watershed. Strain BLYR was run in conjunction with S. cerevisiae strain BLYES (bioluminescent yeast estrogen screen) to determine whether interference could be diluted out without a subsequent loss in the estrogenic signal. Low BLYR output was reported only at high concentrations of $\mathrm{MeOH}(>10 \%)$, DMSO (>2.5\%) and $17 \beta$-estradiol $(>0.25 \mathrm{ng} / \mathrm{mL})$. There was only significant cell mortality at the highest concentrations of $\mathrm{MeOH}(50 \%)$ and DMSO (5\%). Despite evaluating a range of BLYR output (3.21 - 98.61\%) in environmental and $17 \beta$-estradiol samples, we only observed $\pm 5 \%$ mortality as compared to the control. Periphyton samples reported significantly higher interference as compared to water samples. There were minimal but site specific interference among water samples. Seasonally, summer and fall water samples have higher interference as compared to winter and spring. The dilution of individual samples resulted in a
\end{abstract}


reduction of interference; however there was not a linear response in BLYES results suggesting diluting samples may be a viable option on a case-by-case basis. The comparison of strains BLYR and BLYES in diluted samples yielded variable results. Despite the minimal interference in water samples, it is recommended to report the BLYR interference along with estrogenicity values. This would aid in evaluating spatial and temporal trends; specifically outlier analysis. Due to the high reporter interference, it is recommended to only qualitatively assess estrogenicity in periphyton samples. 


\section{Introduction}

Biological assays (bioassays) are designed to quantify an effect in the context of a living organism. Estrogenic endocrine disrupting compounds (EEDCs) are a group of compounds which have been shown to modulate estrogen receptor-mediated pathways in aquatic organisms (Campbell et al. 2006). Many of these compounds (which include both steroidal and nonsteroidal chemicals) have been correlated to deleterious biological effects in fishes (Segner et al. 2013; Senthilkumaran 2015). Routledge and Sumpter (1996) described a yeast (Saccharomyces cerevisiae) bioassay which incorporates human estrogen receptor (hER) into the yeast genome, as well as the reporter gene $L a c-Z$. This allows for the identification of compounds which activate this specific pathway and is termed the yeast estrogen screen assay (YES). Sanseverino et al. (2005) further developed the strain S. cerevisiae and instead of the colorimetric Lac-z reporter, they incorporate the bioluminescent $\operatorname{lux} A / B$ reporter. This strain is termed bioluminescent yeast estrogen screen (BLYES). The new strain S. cerevisiae BLYES yielded a similar detection range of $17 \beta$-estradiol standards; however shortened the duration of the assay from 72 hours to 6 hours.

An important component of bioassays is the determination of cellular viability both before and after a challenge experiment. This ensures that the observed effect is not due to cell death (termed toxicity) but from the experimental agent. The strain S. cerevisiae BLYR(a) was first published by Eldridge et al. (2007) and was designed to constitutively express the $l u x A / B$ bioluminescent reporter. This was done to report cytotoxicity among (in this example) potentially androgenic compounds (incorporating human androgen receptor instead of hER and termed the bioluminescent yeast androgen screen (BLYAS)). The authors identified toxicity by a reduction in the bioluminescent reporter as compared to a control. Sanseverino et al. (2009) 
analyzed a comprehensive suite of compounds and quantified the estrogenic and androgenic potential using the BLYES and BLYAS assays as well as the toxicity as reported by BLYR.

Strain S. cerevisiae BLYES has been used to report estrogenicity in a variety of aquatic systems (Ciparis et al. 2012; Iwanowicz et al. 2016). Variability among EEQBLYEs in the middle and upper Potomac River watershed is reported in Chapter Three; however the possible contribution to this variance because of reporter interference was not discussed. An investigation into these data may yield insights as to the site-specific variability observed.

To our knowledge, there are no data quantifying the toxicity reported in strain $S$. cerevisiae BLYR in environmental samples. Interference is defined as a significant deviation from the control luminescence. The specific objective of this study was to determine whether the interference (specifically the lower output luminescence) determined by the BLYR assay constitutes dead cells as reported by flow cytometry. A subsequent objective was to determine the variability in the BLYR assay to differing concentrations of the solvents absolute methanol $(\mathrm{MeOH})$ and dimethyl sulfoxide (DMSO), as well as $17 \beta$-estradiol (E2) and environmental samples. An additional objective of our study was to examine the potential interference in the estrogenicity assay using the BLYR reporter with environmental samples from the middle and upper Potomac River watershed.

\section{Methods}

\section{$\underline{\text { 2.1. Field collection }}$}

Fifteen sites along streams located within the Potomac River watershed in West Virginia, Maryland, and Virginia were selected for surface water sampling based on the historic presence of EEDCs or sites of interest by fisheries biologist staff from the West Virginia Division of 
Natural Resources (Figure 1). These 15 reconnaissance sites were sampled monthly from 26June-2013 through 18-June-2014 (Table 1). Two grab water samples were collected from a nearshore location using one chemically clean $1 \mathrm{~L}$ amber glass bottle (referred to as filtered samples; I-Chem, Rockwood, Tennessee). A subset of three sites from the original 15 was selected and sampled biweekly for 16 months to evaluate fluctuation at a finer time scale (Table 1). Biweekly sampling occurred between 30-June-2014 and 14-December-2015. Along with the physical parameters described above, beginning with the first sampling date in 2015 (13-January) through the final collection date (14-December), an additional discrete water sample was collected in one clean sterile $500 \mathrm{~mL}$ HDPE bottle (Thermo Fisher Scientific, Waltham, Massachusetts). These samples were defined as unfiltered. Filtered samples contain soluble and small particulate $(<0.7$ $\mu \mathrm{m})$ compounds present in the water column while unfiltered samples also contained larger particulates.

A periphyton sample was collected at every sampling event in both the reconnaissance and biweekly sampling periods by scraping organic benthic material from the surface of submerged rocks and woody debris into a sterile $50 \mathrm{~mL}$ conical tube (Becton Dickenson, Franklin Lakes, New Jersey). Benthic mats of periphyton were targeted based on dark green coloration, leathery texture and the strong smell from 2-methylisoborneol.

\subsection{Laboratory preparation and extraction}

Filtered water samples were treated with hydrochloric acid until the $\mathrm{pH}$ was at 3.0 and stored at $4{ }^{\circ} \mathrm{C}$ no longer than 2 weeks until extraction as recommended by Havens et al. (2010). Unfiltered water samples were subjected to three freeze-thaw cycles to room temperature to disrupt the cells (Graham et al. 2010; Loftin et al. 2008). Periphyton samples were centrifuged at $500 \mathrm{x} g$ for 10 minutes. After centrifugation, supernatant was removed retaining the periphyton 
pellet. Centrifuged periphyton samples were lysed by three freeze-thaw cycles (brought to room temperature) to ensure that all targeted compounds were released from the cells (Graham et al. 2010; Loftin et al. 2008). Lysed samples were stored at $-20^{\circ} \mathrm{C}$ until extraction.

Filtered and unfiltered water samples were extracted using methods modified from Ciparis et al. (2012). Briefly, samples were pre-filtered using a $0.7 \mu \mathrm{m} \mathrm{AP40} \mathrm{GF/F} \mathrm{filter}$ (Millipore Corporation, Billerica, Massachusetts) prior to extraction (unfiltered samples were adjusted to $\mathrm{pH} 3.0$ with $6 \mathrm{~N}$ hydrochloric acid prior to filtration). Water samples were prepared by solid phase extraction (SPE) using OASIS® HLB (200mg) glass cartridges (Waters Corporation, Milford, Massachusetts). Cartridges were conditioned using $5 \mathrm{~mL}$ each of ethyl acetate, 50:50 MeOH:dichloromethane, $\mathrm{MeOH}$, and $\mathrm{MiQ}-\mathrm{H}_{2} \mathrm{O} \mathrm{pH}$ 3.0. Eight hundred $\mathrm{mL}$ of each water sample was run through the cartridge by continuous vacuum using methods modified from Laganà et al. (2004). Two subsequent $6 \mathrm{~mL}$ eluents of $\mathrm{MeOH}$ and 50:50 methanol:dichloromethane were reduced to dryness. Eluates were solubilized in $\mathrm{MeOH}$ such that the final extraction ratio was $800: 1$. Samples were stored at $-20^{\circ} \mathrm{C}$ until analysis.

Periphyton samples were extracted using methods modified from Mohamed et al. (2006). Once the sample weight was recorded, $6 \mathrm{~mL}$ of absolute $\mathrm{MeOH}$ was added. Samples were vortexed for 3 minutes, followed by centrifugation at $500 \mathrm{~g}$ for 10 minutes. Supernatant was retained and the process was repeated a second time with 50:50 MeOH:dichloromethane. Each supernatant sample was filtered using a $0.7 \mu \mathrm{m}$ Whatman ${ }^{\circledR}$ Purdisc 13 syringe filter (Whatman, Maidstone, United Kingdom). Once filtered, both samples were reduced to dryness, then solubilized with $\mathrm{MeOH}$ and pooled such that the final sample volume was $500 \mu \mathrm{L}$. Samples were stored at $-20^{\circ} \mathrm{C}$ until analysis. 


\subsection{Determination of toxicity, interference, and viability}

In order to evaluate toxicity or interference with the bioreporter, samples were screened at the same assay dilution used for estrogenicity using the constitutive bioluminescence strain $S$. cerevisiae BLYR (Eldridge et al. 2007). Strain BLYR was purchased from 490 Bio Tech (Knoxville, Tennessee). This strain was grown under identical conditions of strain S. cerevisiae BLYES and then brought to approximately $\mathrm{OD}_{600}$ of 0.40 . The assay was performed in sterile 96-well white plates (Costar, Corning Incorporated, Corning, New York). Sample extracts were diluted 5\% in $100 \mu \mathrm{L}$ yeast minimal media (YMM) and placed in each well. Control samples were added in duplicate to each plate. S. cerevisiae BLYR was then added to each well (100 $\mu \mathrm{L})$ resulting in a final $\mathrm{MeOH}$ concentration of $2.5 \%$. Each plate was incubated for 4 hours at $30^{\circ} \mathrm{C}$ on an orbital shaker. Luminescence was quantified using a SpectraMax M4 (Molecular Devices, Sunnyvale, California) with the integration time at 500 milliseconds and automatic photo multiplier tube gain. Data were reported as the ratio of sample to a $2.5 \% \mathrm{MeOH}$ control. The detection limit of the BLYR assay was determined by quantifying the variance among $962.5 \%$ $\mathrm{MeOH}$ control wells. The interference threshold is defined as the mean $\pm 3 \mathrm{SD}$ about the mean.

A range of 17ß-estradiol (E2) standards (10.0, 5.0, 1.0, 0.5, 0.25, 0.125, 0.063, 0.031, $0.016,0.008$, and $0.004 \mathrm{ng} / \mathrm{mL})$, as well as a range of $\mathrm{MeOH}(20.0,10.0,5.0,2.5,1.25,0.625$, and $0.313 \%)$ and DMSO concentrations (5.0, 2.5, 1.25, 0.625, 0.313, 0.15625, and 0.078\%) and a subset of filtered water and periphyton extracts which previously reported a wide range of BLYR output percentages were all evaluated. The output ratios for $\mathrm{MeOH}$ and DMSO treatments were compared to media-only wells and all environmental samples were compared to the $2.5 \%$ $\mathrm{MeOH}$ control wells. Following the measurement of luminescence, samples were centrifuged for 10 minutes at $805 \times g$ and supernatant removed. A 1\% solution of propidium iodide (Molecular 
Probes, Eugene, Oregon) was prepared in sterile Dulbecco's phosphate buffered saline (pH 7.4;

DPBS; Sigma Aldrich, St. Louis, Missouri) and $100 \mu \mathrm{L}$ was added to each well and incubated on a rotary shaker for 30 minutes (protected from light). The samples were centrifuged for 10 minutes at $805 \times g$, supernatant removed and washed using $100 \mu \mathrm{L}$ of DPBS. Viability was quantified via flow cytometry on an Amnis ${ }^{\circledR}$ FlowSight $^{\circledR}$ (MilliporeSigma, Billerica, Massachusetts). Ten thousand events were analyzed using the $488 \mathrm{~nm}$ laser, channel four. Analysis was performed with IDEAS 6.2 software (Amnis/MilliporeSigma, Billerica, MA). An example of the gating strategy is shown in Figure 2. First, all single cells which were in focus were targeted (represented by the green box in Figure 2B and expanded as Figure 2B). Next, a second gate was created which identified only those dead cells accounting for auto-florescence in live cells. Dead cells report relatively high propidium iodide intensity and are indicated in Figure $2 \mathrm{C}$ by the pink box. The frequency distribution and grouping of these dead cells are presented in Figures 2D. Examples of propidium iodide positive and negative cells are presented in figures $2 \mathrm{eE}$ and $2 \mathrm{~F}$, respectively. Dead cells are defined as propidium iodide-positive and live cells as propidium iodide-negative. This gating template was used for all samples. Apoptotic-like cells were identified (Figure 3 ) in which the nucleus is small and compact when compared to the normal cell morphology (George et al. 2004; Henery et al. 2008; Vorobjev and Barteneva 2017). This gating strategy was used on all samples. Outputs are recorded as the percent of dead or apoptotic-like cells. Cell densities are recorded for all samples (noting that cells were optimized according to optical density, not specific cell density prior to plating).

\subsection{Statistical Analysis}

All analysis was performed using the R statistical software. Statistical significance was determined at $\alpha=0.05$. Analysis of Variance (ANOVA) test with a Tukey's Honest Significance 
test (if statistically significant differences were reported) was used to compare site differences pooled across month and year, as well as the monthly differences pooled across all sites and years. An ANOVA accompanied with the Tukey's Honest Significance test was also used to identify differences among sites within season/year. Seasons were defined as spring occurring between March, April, and May; summer occurring between June, July, and August; fall occurring between September, October, and November; winter occurring between December, the following January, and February (the year associated with winter corresponds to January and February). Filtered and unfiltered water fractions were compared using a Student's t-test.

\section{Results}

\subsection{Viability and interference among Solvent, E2, and water samples}

All samples were screened for reporter interference/toxicity/viability. The interference threshold for the BLYR assay was determined to be $11.0 \%$. BLYR and viability results are summarized in Table 2. In general, an increase of interference as reported by BLYR was associated with higher $\mathrm{E} 2$ and $\mathrm{MeOH}$ concentrations. The range of BLYR output among $\mathrm{MeOH}$ was 47.9 to $117.6 \%$ and the range of BLYR output for E2 was $61.5 \%$ to $98.6 \%$. The background mortality in our unchallenged cells was $10.7 \%$. To better represent the dead cells resulting from each respective treatment, this value was subtracted from the absolute mortality for each

treatment and presented this as the adjusted percent dead cells. The highest adjusted mortality in $\mathrm{MeOH}$ and $\mathrm{E} 2$ challenged cells was extremely minimal $(0.8 \%)$. There was no dose-dependent pattern for either compound.

A kinetic difference in BLYR output was noted when testing the solvents. At the highest three $\mathrm{MeOH}$ concentrations $(20,10$, and 5\%) output was suppressed during the first two hours of 
the experiment (Figure 4). Following this time, the cells exposed to 5\% $\mathrm{MeOH}$ were within the range of the lower four concentrations. The cells exposed to 20 and $10 \% \mathrm{MeOH}$ concentrations remained below all other $\mathrm{MeOH}$ concentrations. The highest two DMSO concentrations (5.0 and $2.5 \%$ ) suppressed output as compared to the other five concentrations throughout the experiment (Figure 5). There were no differences among the lower concentrations.

There was a relatively wide range of interference among water and periphyton samples. The range of BLYR output among water samples was 29.9 to $102.2 \%$ and periphyton was 3.8 to $57.2 \%$. Interestingly, there was a minimal change in adjusted mortality among these samples ranging from -1.7 to $1.2 \%$ in water and -4.5 to $1.4 \%$ in periphyton. There was no discernible trend in BLYR percentage and percent mortality or apoptotic-like cells in either water or periphyton samples.

Our final experiment was to determine the feasibility of diluting out interference without losing EEQ вLYEs sensitivity (Table 3). A decrease in interference was reported for each dilution in each sample (regardless of medium); however only three samples (all were filtered water) were diluted above our interference threshold. There was not a subsequent linear change in EEQ dilution while all were decreased at the $75 \%$ dilution. One periphyton sample increased from below detection to quantifiable only at the $75 \%$ dilution while all diluted $50 \%$ were never reported above detection.

\subsection{Environmental Samples}

The average BLYR output ratio grouped by site is presented in Figure 6. There was no significant difference among sites in either filtered water or periphyton during the reconnaissance 
sampling period. None of the filtered water samples exhibited interference while all of the periphyton samples showed significant reduction in BLYR output (Figure 6A). During the biweekly sampling time period, both filtered and unfiltered water fractions at the North Branch Cumberland (MS4) were significantly lower than those from either of the South Branch Potomac sites (Figure 6B). There were no differences among sites in periphyton.

Minimal variability was noted among months in filtered water samples (Figure 7). There was a slight decrease in the average output ratio in the months of October and December as compared to some of the sites. In general, samples collected in the spring and summer had less interference than those collected in the fall and winter. There were no differences in unfiltered water or periphyton samples. There were no differences among filtered and unfiltered samples.

The individual sample temporal data among filtered water, unfiltered water and periphyton are presented at the three intensive sites in Figures 8-10. In general there was low sample variability in the two water fractions in the two South Branch sites and considerable variability in the North Branch site (numerous yet randomly distributed samples below the interference threshold). Considerable variability in periphyton samples was also found for all three sites. A similar overall trend among sample mediums were observed in the remaining reconnaissance sampling sites as well. The mean and range of standard deviations among all sites were $1.95 \%(0-9.19 \%), 1.56 \%(0-4.24 \%)$, and $2.50 \%(0-32.17 \%)$ for filtered water, unfiltered water and periphyton, respectively. Despite the individual sample variability, the average output ratio for all three mediums in subsequent results is reported below.

The final analysis was to compare the sample site variability between season/year. These data are presented in Figures 11-13. During the reconnaissance period, the Monocacy river near Frederick, Maryland was significantly higher than Shenandoah River at Millville, West Virginia, 
the South Branch at Petersburg, West Virginia, the South Branch near Springfield, West Virginia, the North Fork of the South Branch near Seneca Rocks, West Virginia, the North Branch at Cumberland, Maryland, the mainstem of the Potomac river near Sharpsburg, Maryland, and mill creek near Romney, West Virginia. There were no differences in either filtered water (Figure 11A) or periphyton (Figure 13A) during the reconnaissance sampling period. During the biweekly sampling time period, the North Branch site at Cumberland was significantly lower than the two South Branch sites during the Fall 2014 and Winter 2015 (filtered water), and Winter 2015 and Fall 2015 (unfiltered water). An apparent site difference is noted in filtered and unfiltered water during the winter 2016; however this represents only one sampling event and statistical differences were not calculated. There were no differences in periphyton between sampling sites during the biweekly time period.

\section{Discussion}

The BLYES assay is used to measure relative estrogenicity as compared to an E2 standard curve. Utilizing the BYLR assay high concentrations of $\mathrm{MeOH}(>20 \%)$ caused interference above our threshold, however these are concentrations not likely to be utilized in the assays. The increased BLYR luminescence values did not correlate to cell density; thus the mechanism remains unclear. No reporter interference was reported in E2 standards $<0.25$ $\mathrm{ng} / \mathrm{mL}$. This concentration corresponds to $9.2 \times 10^{-9} \mathrm{M}$ and is consistent with the upper bounds reported by Sanseverino et al. (2009). Based on their guidelines for data acceptance, it is recommended to use this value as the upper reporting limit with the BLYES assay.

The wide range of interference reported in environmental samples was not associated with mortality, apoptotic-like cells, or cell density. This interference may result in the underreporting of estrogenicity data (although the specific source remains unclear). Table 3 
reports a decrease of the interference in environmental samples without a subsequent linear response in estrogenicity. In the absence of matrix effects, estrogenicity would be expected to be diluted out. However as interference decreased, estrogenicity increased in some samples which would suggest that at higher sample concentrations, the signal is being suppressed by the interference. Although the specific source of interference cannot be pinpointed, this may suggest a possible underreporting of estrogenicity due to reporter interference. This would need to be verified on a sample-by-sample basis.

A possible source for seasonal interference may be stream discharge. Figure 14 presents the mean daily discharge at the South Branch Potomac near Springfield, West Virginia (U.S. Geological Survey National Water Information System ID 01608070) and the North Branch Potomac River near Cumberland, Maryland (U.S. Geological Survey National Water Information System ID 01603000). Both sites experienced relatively higher discharge between the months of January and July (regardless of year) with episodic high flow events. Conversely, lower flows were observed in the late summer through early winter months. These lower discharges may result in a concentrating of EDCs or other compounds detrimental to strain $S$. cerevisiae BLYR. Kolpin et al. (2004) reported a decrease in organic wastewater contaminants in higher flow events which they believe resulted from the dilution of those compounds. Further research is required to quantify the temporal distribution of specific compounds at these sites.

An additional source of interference may be the compounds associated with land cover/land use (e.g. endocrine disrupting compounds (EDCs)). The land cover classified among each watershed was analyzed in chapter three and is represented here in Tables 4-6. In general, the North and South Branch sites are quite similar (heavily forested with localized agriculture). One noteworthy difference is the number of WWTPs in the North Branch Cumberland site; 
however, Iwanowicz et al. (2009) documented that the negative reproductive effects in fish were not associated with WWTPs which would suggest additional influence from another source (such as agriculture). The Monocacy and three Shenandoah sites report a greater percentage of agricultural and developed land use. The agricultural contribution to in-stream EDCs are well documented (Alvarez et al. 2009; Ciparis et al. 2012; Fairbairn et al. 2016; Young et al. 2014). The estrogenic biological effects of pesticides are reviewed by Hayes et al. (2011). Disruption by atrazine extends to the invertebrate community as well (DeLorenzo et al. 2001). Sanseverino et al. (2009) reported toxic effects in select pesticides (such as atrazine) but not others (such as $o, p^{\prime}$-DDT). They also report variable toxicity in other classes of compounds (pharmaceutical, hormone, etc.) Further research is necessary to quantify temporal distribution of these compounds and the possible association on BLYR reporter interference.

These environmental samples are the same which were assessed using EEQBLYES in chapter four. Based on a simple linear regression comparing the BLYR and EEQBLYES results across all sites and sample dates, there was a weakly significant correlation in these data $(\mathrm{p}=$ $\left.0.005 ; r^{2}=0.023\right)$. Although this correlation is very weak, the interference may (in-part) influence the seasonal variability in $\mathrm{EEQ}_{\text {BLYEs }}$ as reported in chapter four, Figure 2. Additionally, this interference may influence the site variance as reported in chapter four, Table 2. However, given the weak nature of the association, there are likely other factors resulting in the EEQ вLYES trends.

The seasonal trend in interference is similar to the seasonal trend in total microcystins/nodularins as reported in chapter two. This association was weakly positive for all three sample mediums (as defined by Hinkle et al. (2003)) using Spearman's rank-order correlation. Both filtered water $(\mathrm{p}=0.012 ; \rho=0.167)$ and periphyton $(\mathrm{p}<0.001 ; \rho=0.287)$ were 
significantly correlated with BLYR output; however there was not a significant association with unfiltered water $(p=0.138 ; \rho=0.173)$. Although biomass was not quantified, the association may be evidence of reporter interference by cellular lysate. Molecular disruption has been documented in vertebrates by cyanobacterial lysate (Rogers et al. 2011; Rymuszka and Adaszek 2013; Štěpánková et al. 2011). Additionally, Štěpánková et al. (2011) showed select cyanobacterial species lysate to be cytotoxic. Although there was not an increase in dead or apoptotic cells among treatments, these lysates (particularly periphyton) may contain compounds which disrupt S. cerevisiae metabolism and thus, affect the output luminescence.

Overall, minimal interference was reported among water fractions. However, it is recommended to report both the EEQBLYES and associated BLYR output ratio as this would provide additional details which can aid in interpretation. For example it may provide insights into trend analysis; specifically in explaining deviations (outliers). Caution is recommended for reporting the $\mathrm{EEQ}_{\mathrm{BLYES}}$ in periphyton samples. The interference in these periphyton samples was generally greater than those in either filtered or unfiltered water samples. In cases of extreme interference, it may be more appropriate to report qualitative (presence/absence) data as opposed to quantitative output; however further research is needed to determine what those threshold values should be. As suggested above, interference should be addressed on a sample-by-sample basis. As presented above, sample dilution resulted in a reduction of interference and a nonlinear change in the corresponding EEQ these samples until the interference value is above the quantification threshold if the corresponding EEQвLYEs value is not diluted out of the sample. The final EEQ calculation would simply need to be adjusted to account for the additional dilution. In situations when interference cannot be diluted out without also removing EEQBLYEs, these samples should be reported with 
the lowest possible interference value and flagged as they may be underreporting the total estrogenicity value.

This chapter has principally focused on interference below the critical output ratio threshold. However data are reported well over 100\%. Among MeOH and DMSO, these values were not associated with increased cell density or apoptotic-like cells. This is confounded by the observation that these elevated percentages were reported at the lower concentrations of solvent. In practice, these values are not problematic as they should be consistent across all samples (e.g. environmental samples were all analyzed with $2.5 \% \mathrm{MeOH})$. However this does not address what may be driving these higher output ratios relative to media-only controls. Further research is needed focusing on what may be driving these relatively higher luminescence values in our reporter. 


\section{Literature Cited}

Alvarez, D. A., and coauthors. 2009. Reproductive health of bass in the Potomac, USA, drainage: Part 2. Seasonal occurrence of persistent and emerging organic contaminants. Environmental Toxicology and Chemistry 28(5):1084-1095.

Campbell, C. G., and coauthors. 2006. Biologically directed environmental monitoring, fate, and transport of estrogenic endocrine disrupting compounds in water: A review. Chemosphere 65(8):1265-80.

Ciparis, S., L. R. Iwanowicz, and J. R. Voshell. 2012. Effects of watershed densities of animal feeding operations on nutrient concentrations and estrogenic activity in agricultural streams. Science of the Total Environment 414:268-76.

DeLorenzo, M. E., G. I. Scott, and P. E. Ross. 2001. Toxicity of pesticides to aquatic microorganisms: A review. Environmental Toxicology and Chemistry 20(1):84-98.

Eldridge, M. L., and coauthors. 2007. Saccharomyces cerevisiae BLYAS, a new bioluminescent bioreporter for detection of androgenic compounds. Applied and Environmental Microbiology 73(19):6012-8.

Fairbairn, D. J., and coauthors. 2016. Sources and transport of contaminants of emerging concern: A two-year study of occurrence and spatiotemporal variation in a mixed land use watershed. Science of the Total Environment 551-552:605-13.

George, T. C., and coauthors. 2004. Distinguishing modes of cell death using the ImageStream multispectral imaging flow cytometer. Cytometry A 59(2):237-45.

Graham, J. L., K. A. Loftin, M. T. Meyer, and A. C. Ziegler. 2010. Cyanotoxin Mixtures and Taste-and-Odor Compounds in Cyanobacterial Blooms from the Midwestern United States. Environmental Science and Technology 44(10):7361-7368.

Havens, S. M., and coauthors. 2010. Stability, preservation, and quantification of hormones and estrogenic and androgenic activities in surface water runoff. Environmental Toxicology and Chemistry 29(11):2481-90.

Hayes, T. B., and coauthors. 2011. Demasculinization and feminization of male gonads by atrazine: consistent effects across vertebrate classes. Journal of Steroid Biochemistry and Molecular Biology 127(1-2):64-73.

Henery, S., and coauthors. 2008. Quantitative image based apoptotic index measurement using multispectral imaging flow cytometry: a comparison with standard photometric methods. Apoptosis 13(8):1054-63.

Hinkle, D. E., W. Wiersma, and S. G. Jurs. 2003. Applied Statistics for the Behavioral Sciences. Houghton Mifflin.

Iwanowicz, L. R., and coauthors. 2009. Reproductive health of bass in the Potomac, U.S.A., drainage: part 1. Exploring the effects of proximity to wastewater treatment plant discharge. Environmental Toxicology and Chemistry 28(5):1072-1073. 
Iwanowicz, L. R., and coauthors. 2016. Evidence of estrogenic endocrine disruption in smallmouth and largemouth bass inhabiting Northeast U.S. national wildlife refuge waters: A reconnaissance study. Ecotoxicology and Environmental Safety 124:50-9.

Kolpin, D. W., M. Skopec, M. T. Meyer, E. T. Furlong, and S. D. Zaugg. 2004. Urban contribution of pharmaceuticals and other organic wastewater contaminants to streams during differing flow conditions. Science of the Total Environment 328(1-3):119-30.

Laganà, A., and coauthors. 2004. Analytical methodologies for determining the occurrence of endocrine disrupting chemicals in sewage treatment plants and natural waters. Analytica Chimica Acta 501(1):79-88.

Loftin, K. A., and coauthors. 2008. Comparison of Two Cell Lysis Procedures for Recovery of Microcystins in Water Samples from Silver Lake in Dover, Delaware, with Microcystin Producing Cyanobacterial Accumulations. United States Geological Survey. Open File Report 2008-1341.

Mohamed, Z. A., H. M. El-Sharouny, and W. S. M. Ali. 2006. Microcystin production in benthic mats of cyanobacteria in the Nile River and irrigation canals, Egypt. Toxicon 47:584-590.

Rogers, E. D., and coauthors. 2011. Global gene expression profiling in larval zebrafish exposed to microcystin-LR and microcystis reveals endocrine disrupting effects of Cyanobacteria. Environmental Science and Technology 45(5):1962-9.

Routledge, E. J., and J. P. Sumpter. 1996. Estrogenic activity of surfactants and some of their degradation products assessed using a recombinant yeast screen. Environmental Toxicology and Chemistry 15(3):241-248.

Rymuszka, A., and L. Adaszek. 2013. Cytotoxic effects and changes in cytokine gene expression induced by microcystin-containing extract in fish immune cells--an in vitro and in vivo study. Fish and Shellfish Immunology 34(6):1524-32.

Sanseverino, J., and coauthors. 2009. Screening of potentially hormonally active chemicals using bioluminescent yeast bioreporters. Toxicological Sciences 107(1):122-34.

Sanseverino, J., and coauthors. 2005. Use of Saccharomyces cerevisiae BLYES expressing bacterial bioluminescence for rapid, sensitive detection of estrogenic compounds. Applied and Environmental Microbiology 71(8):4455-60.

Segner, H., A. Casanova-Nakayama, R. Kase, and C. R. Tyler. 2013. Impact of environmental estrogens on Yfish considering the diversity of estrogen signaling. General and Comparative Endocrinology 191:190-201.

Senthilkumaran, B. 2015. Pesticide- and sex steroid analogue-induced endocrine disruption differentially targets hypothalamo-hypophyseal-gonadal system during gametogenesis in teleosts - A review. General and Comparative Endocrinology 219:136-42.

Štěpánková, T., L. Ambrožová, L. Bláha, J. P. Giesy, and K. Hilscherová. 2011. In vitro modulation of intracellular receptor signaling and cytotoxicity induced by extracts of cyanobacteria, complex water blooms and their fractions. Aquatic Toxicology 105(34):497-507.

Vorobjev, I. A., and N. S. Barteneva. 2017. Multi-parametric imaging of cell heterogeneity in apoptosis analysis. Methods 112:105-123. 
Young, J., L. Iwanowicz, A. Sperry, and V. Blazer. 2014. A landscape-based reconnaissance survey of estrogenic activity in streams of the upper Potomac, upper James, and Shenandoah Rivers, USA. Environmental Monitoring and Assessment 186(9):5531-45. 


\section{Figures}

Figure 1. The location of all 15 sites included in this study. All sites were located in the states of West Virginia, Maryland, and Virginia within the Potomac River watershed (inset map).

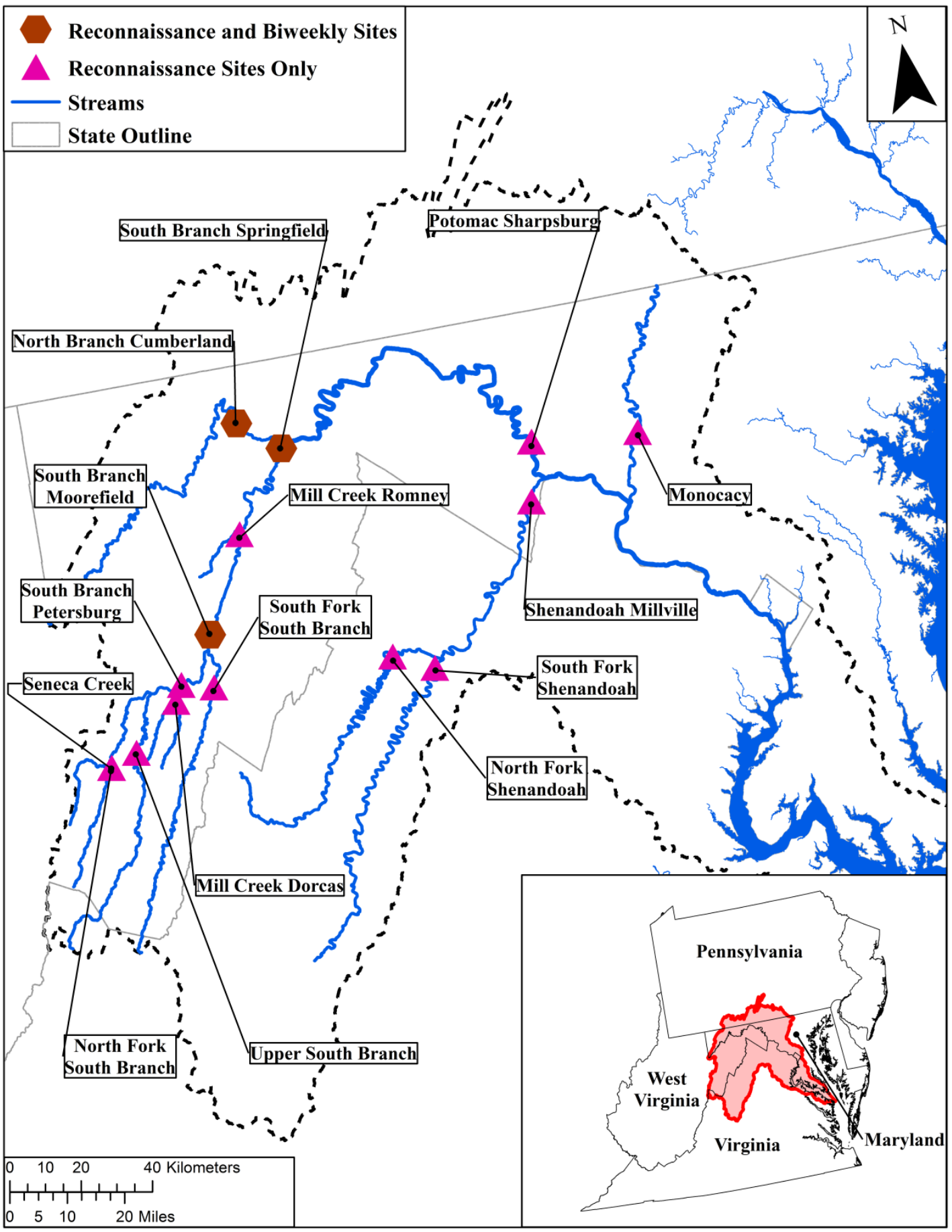


Figure 2. Gating strategy using flow cytometry to identify dead cells (here depicted by cells exposed to $50 \% \mathrm{MeOH}$ and report $93.5 \%$ mortality). A-B. Primary gating of cells A) in focus and B) single cells. C-D. Secondary gating of cells C) dead cells based on intensity of propidium iodide and D) frequency. E-F. Example of cell types based on propidium iodide staining E) positive (dead) and F) negative (live).

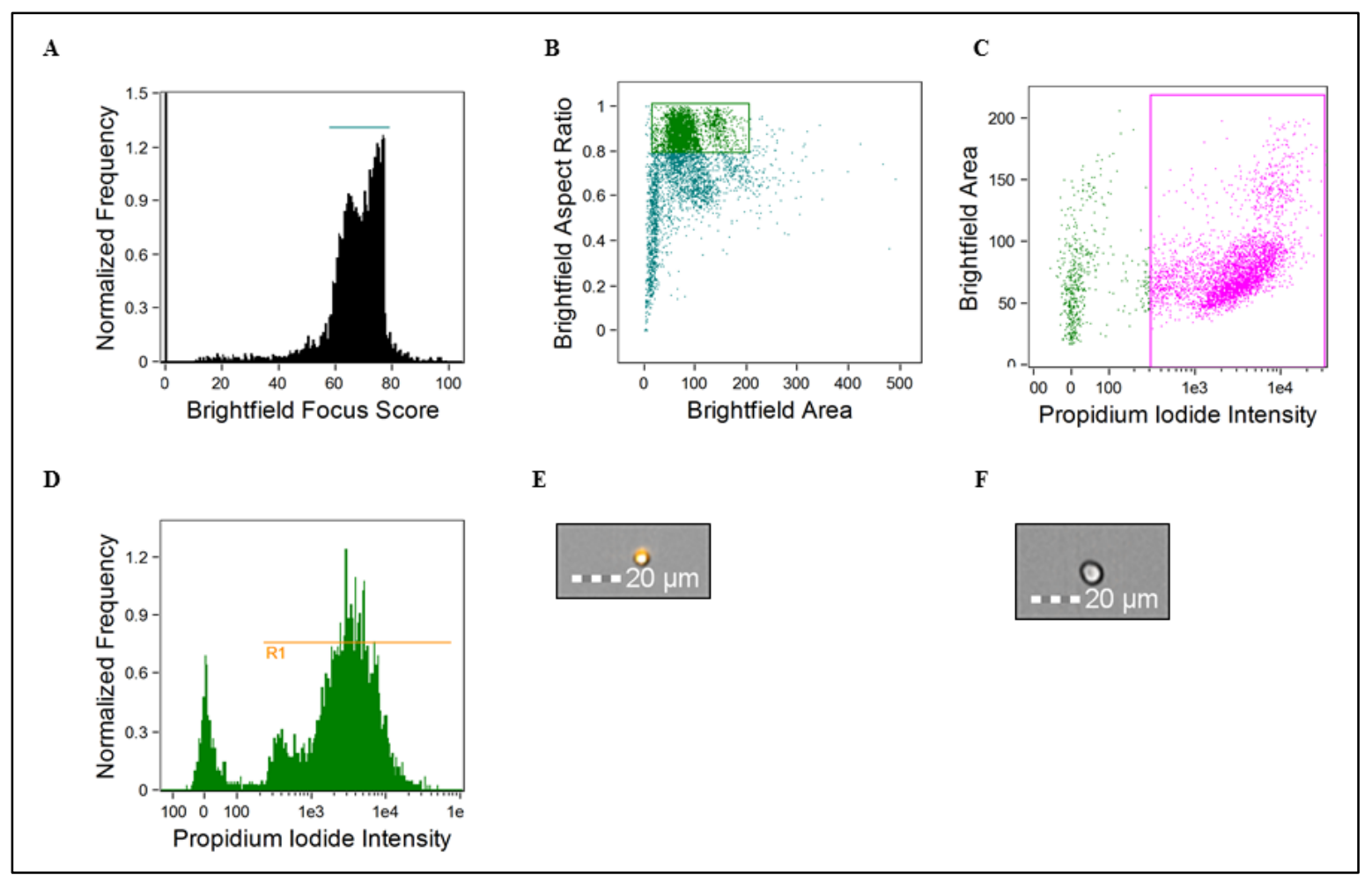


Figure 3. Gating strategy using flow cytometry to identify apoptotic-like cells. A-C identifies different cell populations such as A) Apoptotic-like cell identified as small and compact as compared to B and $\mathrm{C}$ which are two distinct populations pf larger cells with normal morphology (represented here as propidium iodide positive).

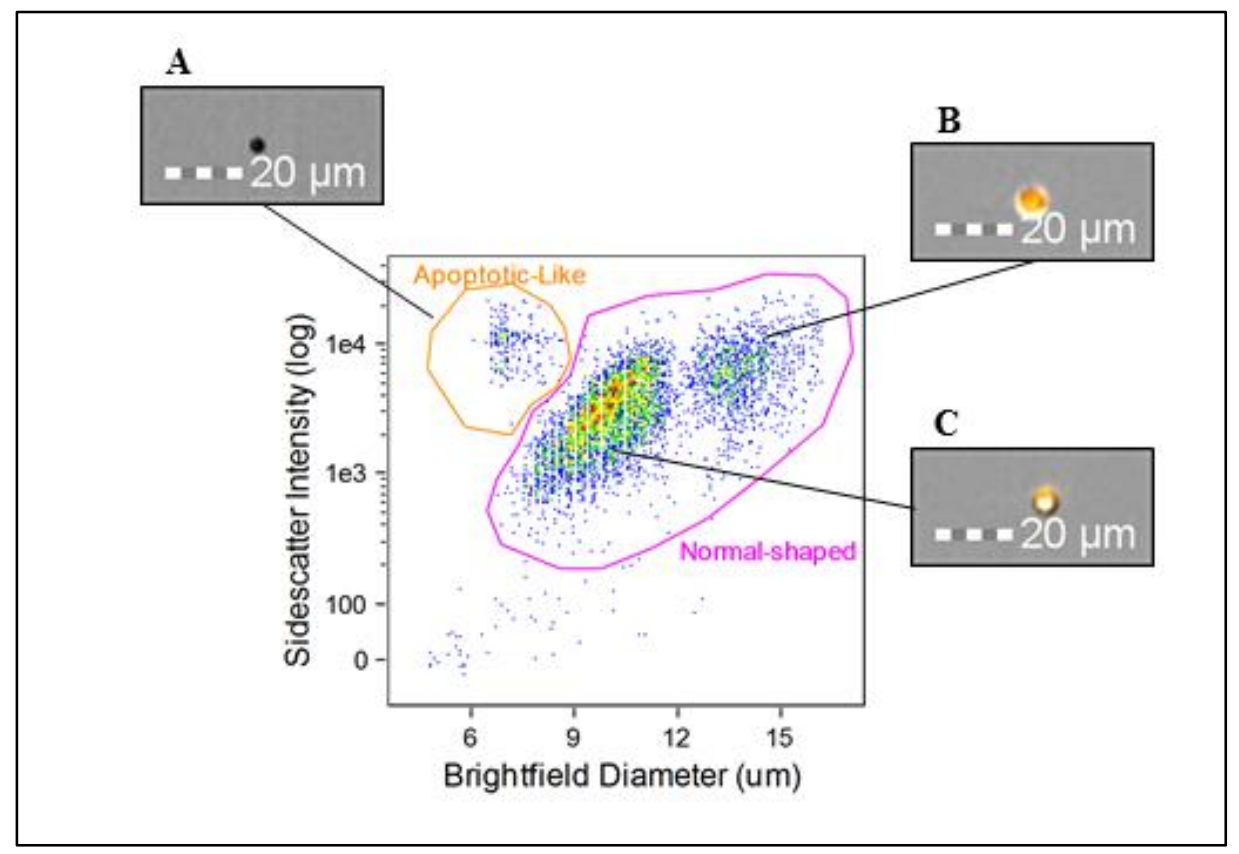


Figure 4. Temporal response of BLYES among varying concentrations of absolute methanol.

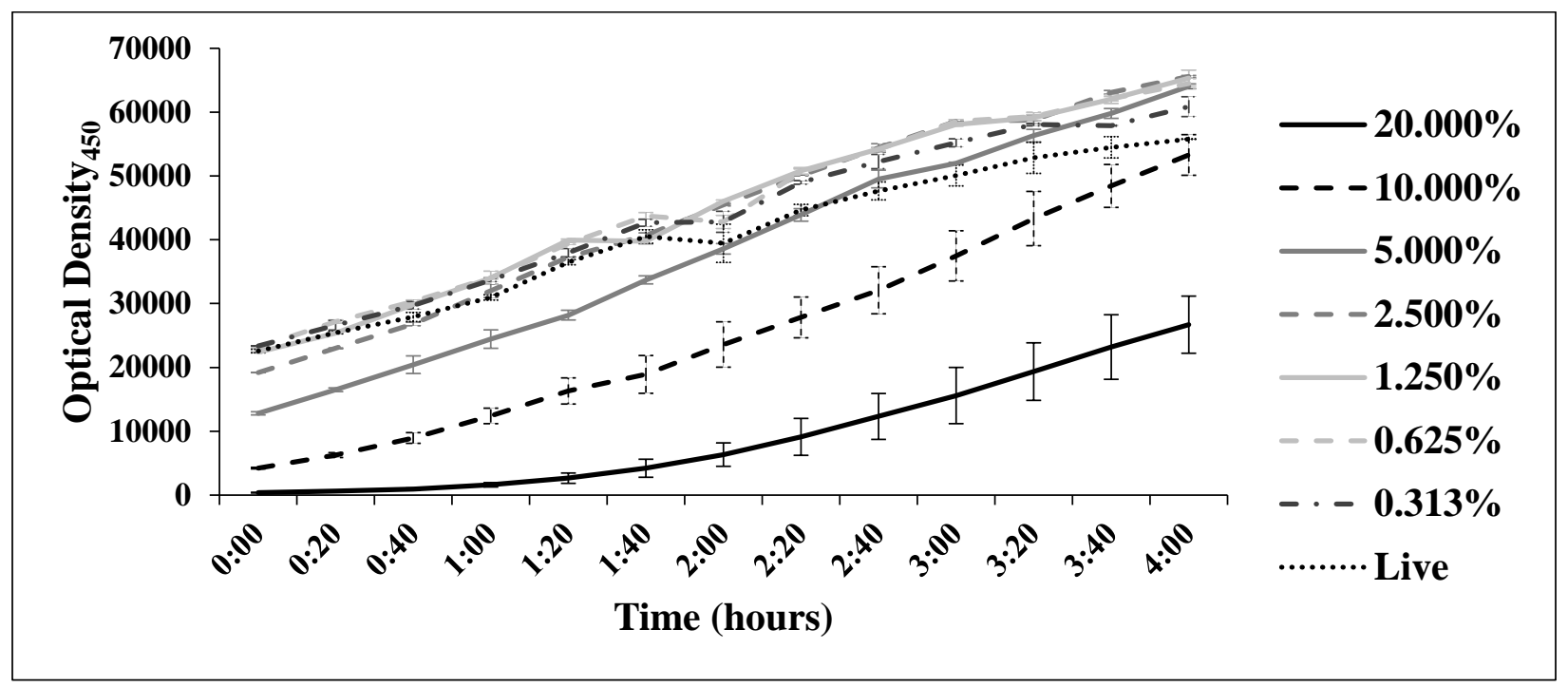


Figure 5. Temporal response of BLYES among varying concentrations of absolute dimethyl sulfoxide.

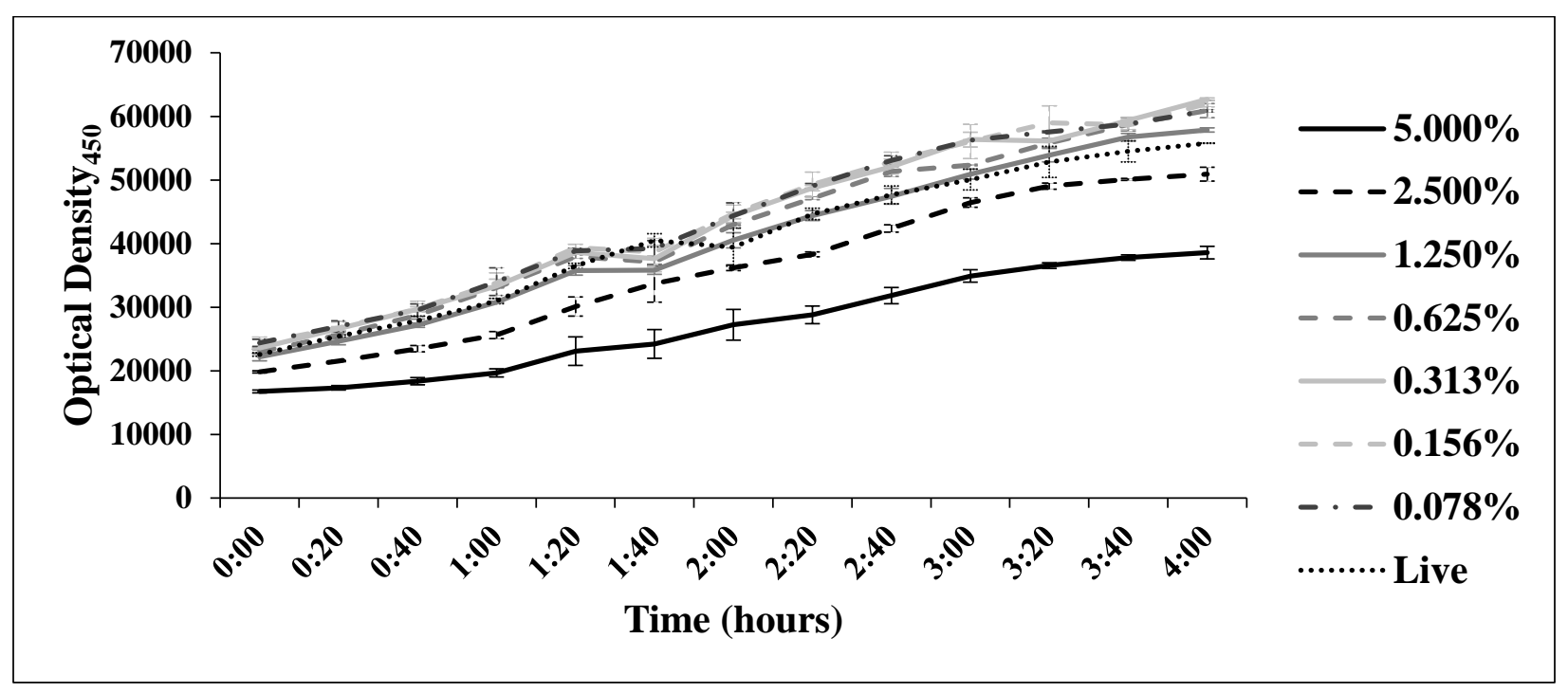


Figure 6. Site in BLYR output ratio values measured in filtered water, unfiltered water, and periphyton samples from the A) reconnaissance and B) biweekly sampling periods. Error bars represent one standard deviation about the mean. The red bar represents the interference threshold.
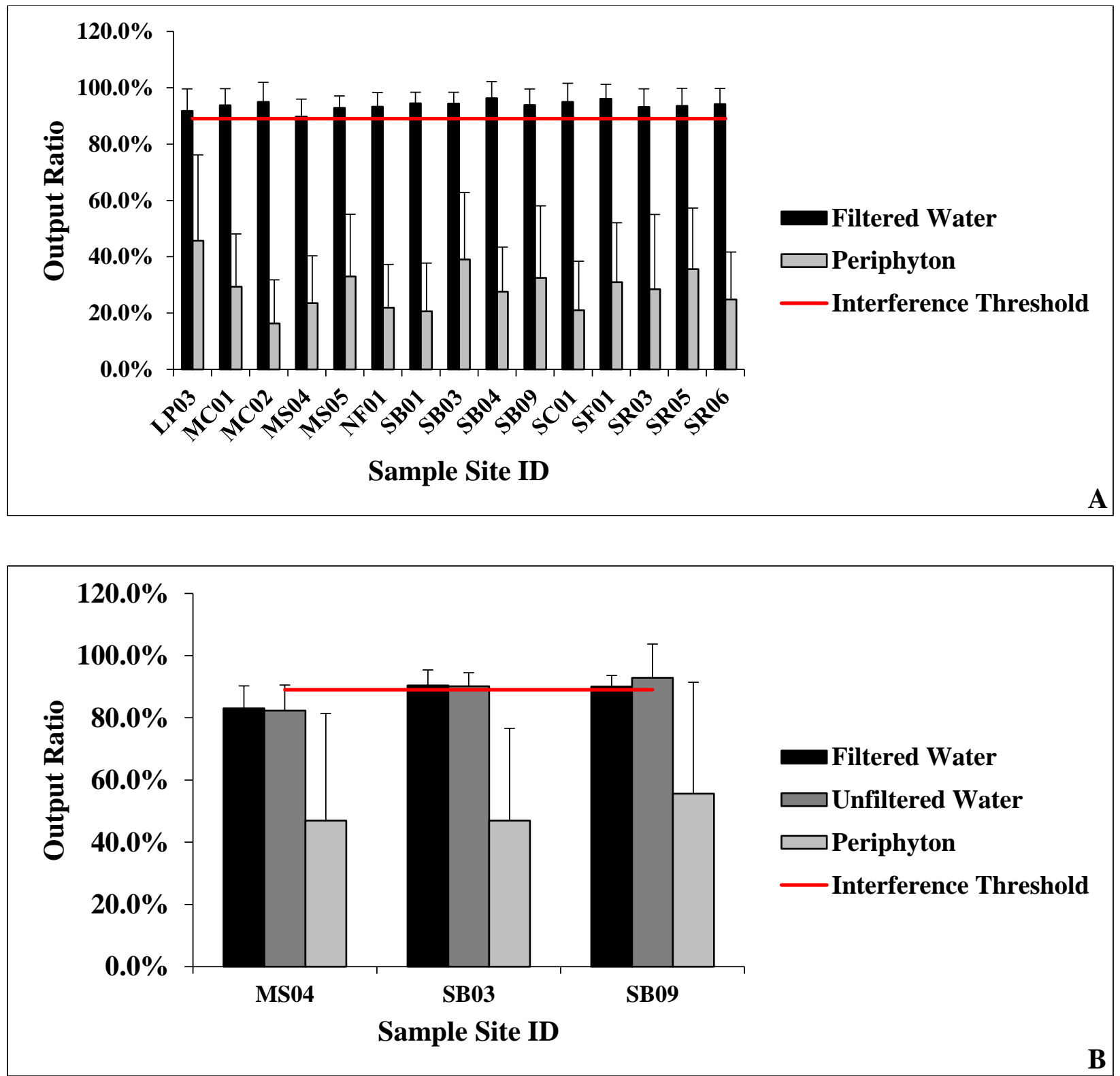
Figure 7. Monthly variability in BLYR output ratio values measured in filtered water, unfiltered water, and periphyton samples. Error bars represent one standard deviation about the mean. Statistical differences in filtered water samples are represented above each bar. There were no significant differences in unfiltered water or periphyton. The red bar represents the interference threshold.

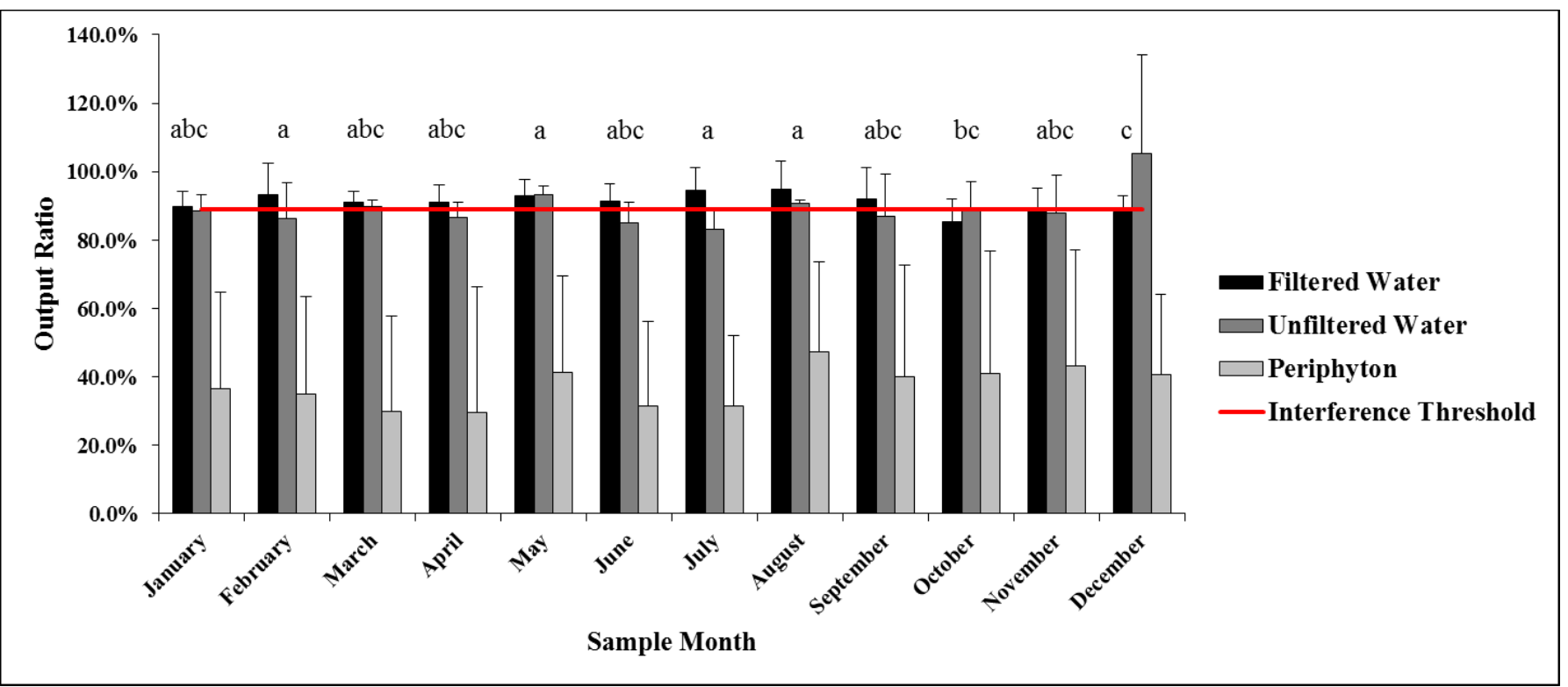


Figure 8. Temporal variability in BLYR output ratio values measured in filtered water samples from biweekly sampling sites. Error bars represent one standard deviation about the mean. The $\mathrm{y}$-axis scale begins at $60 \%$ to focus on the range of values. The $\mathrm{x}$-axis represents specific sampling dates as opposed to a continuous range of dates. The red bar represents the interference threshold.

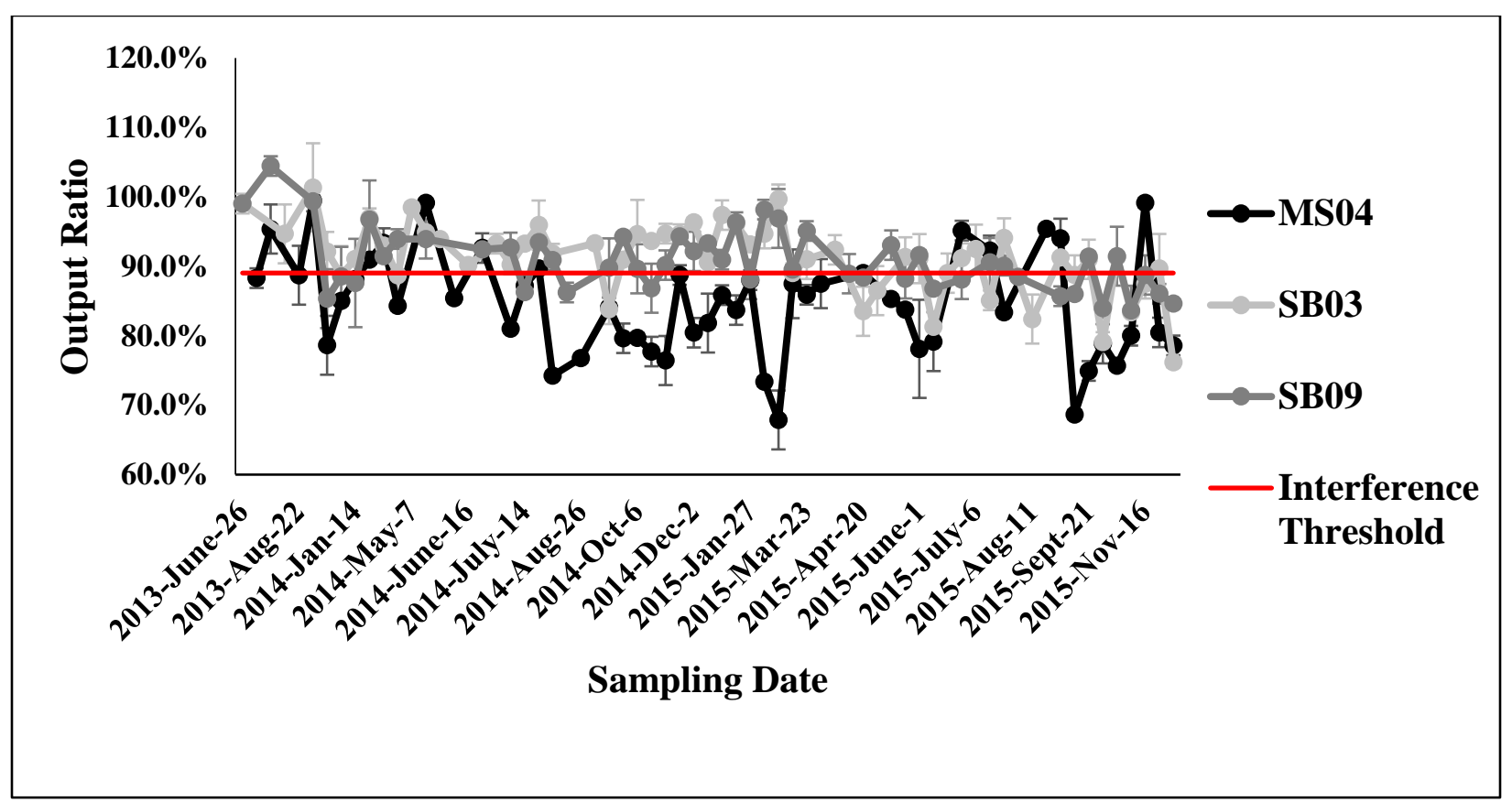


Figure 9. Temporal variability in BLYR output ratio values measured in unfiltered water samples from biweekly sampling sites. Error bars represent one standard deviation about the mean. The $\mathrm{y}$-axis scale begins at $60 \%$ to focus on the range of values. The $\mathrm{x}$-axis represents specific sampling dates as opposed to a continuous range of dates. The red bar represents the interference threshold.

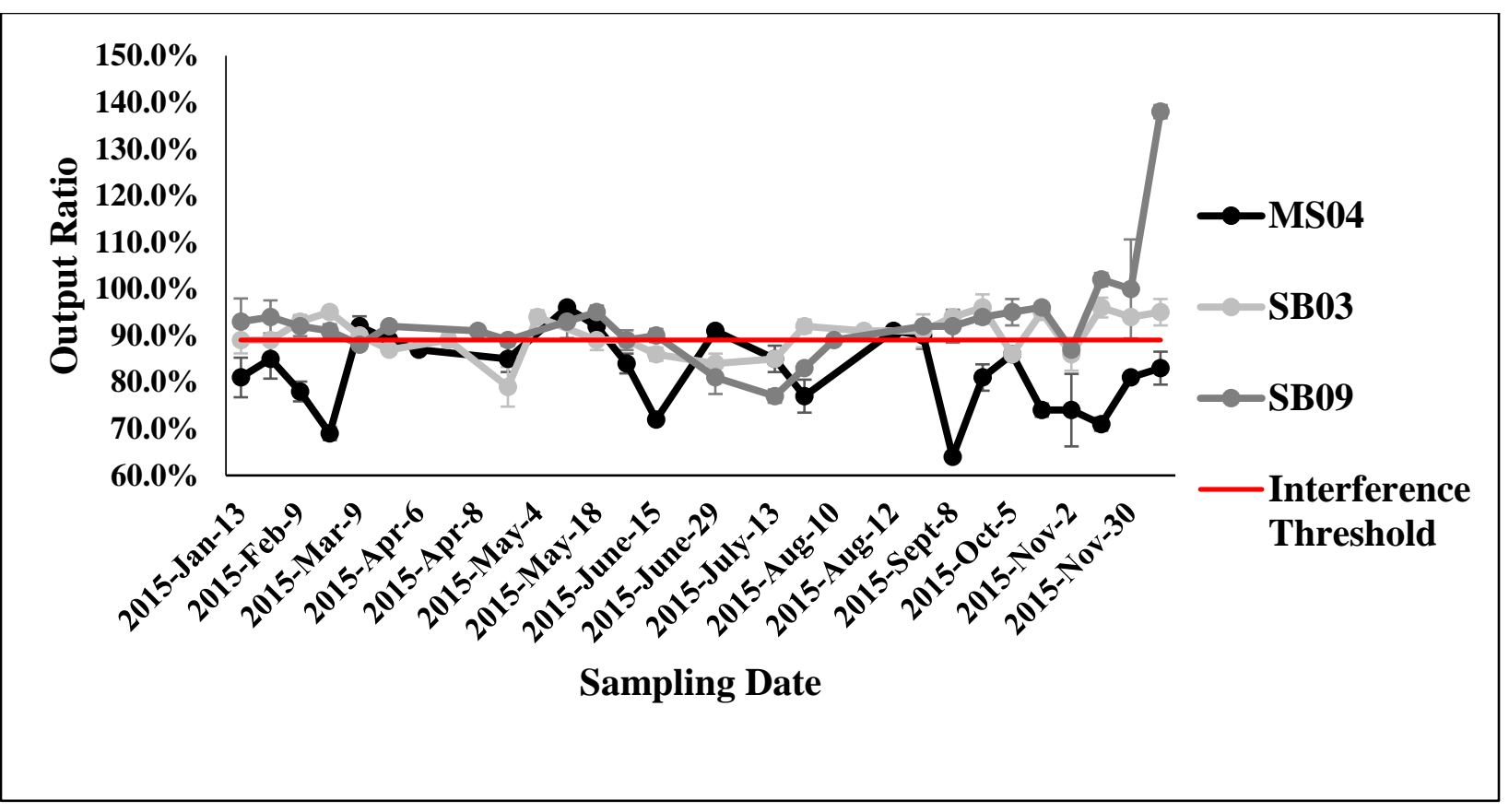


Figure 10. Temporal variability in BLYR output ratio values measured in periphyton samples from biweekly sampling sites. Error bars represent one standard deviation about the mean. The $\mathrm{x}$-axis represents specific sampling dates as opposed to a continuous range of dates. The red bar represents the interference threshold.

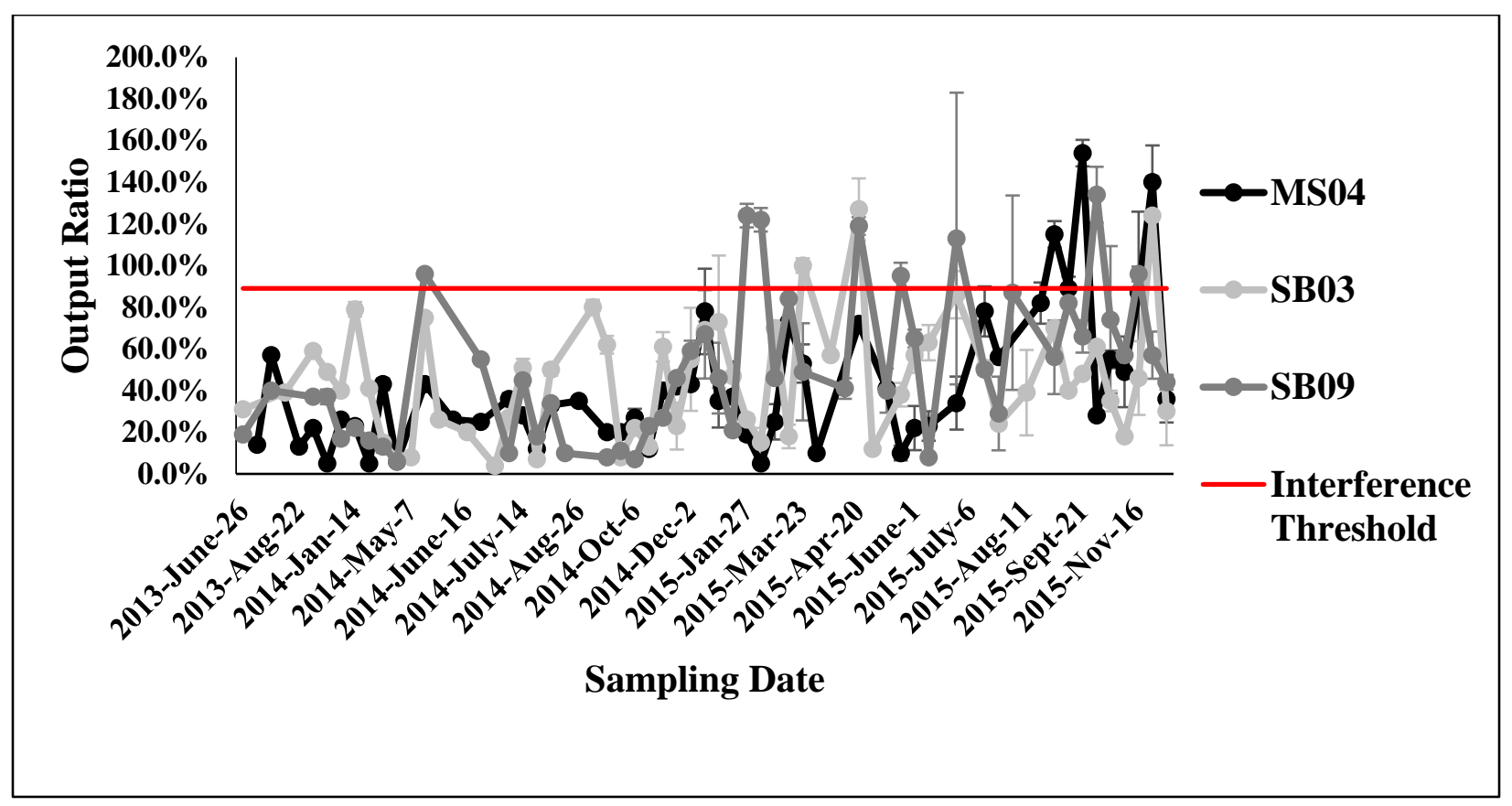


Figure 11. Season/year variability in BLYR output ratio values measured in filtered water samples from A) the reconnaissance and B) biweekly time period. Error bars represent one standard deviation about the mean. The y-axis scale begins at $75 \%$ to focus on the range of values. The red bar represents the interference threshold.
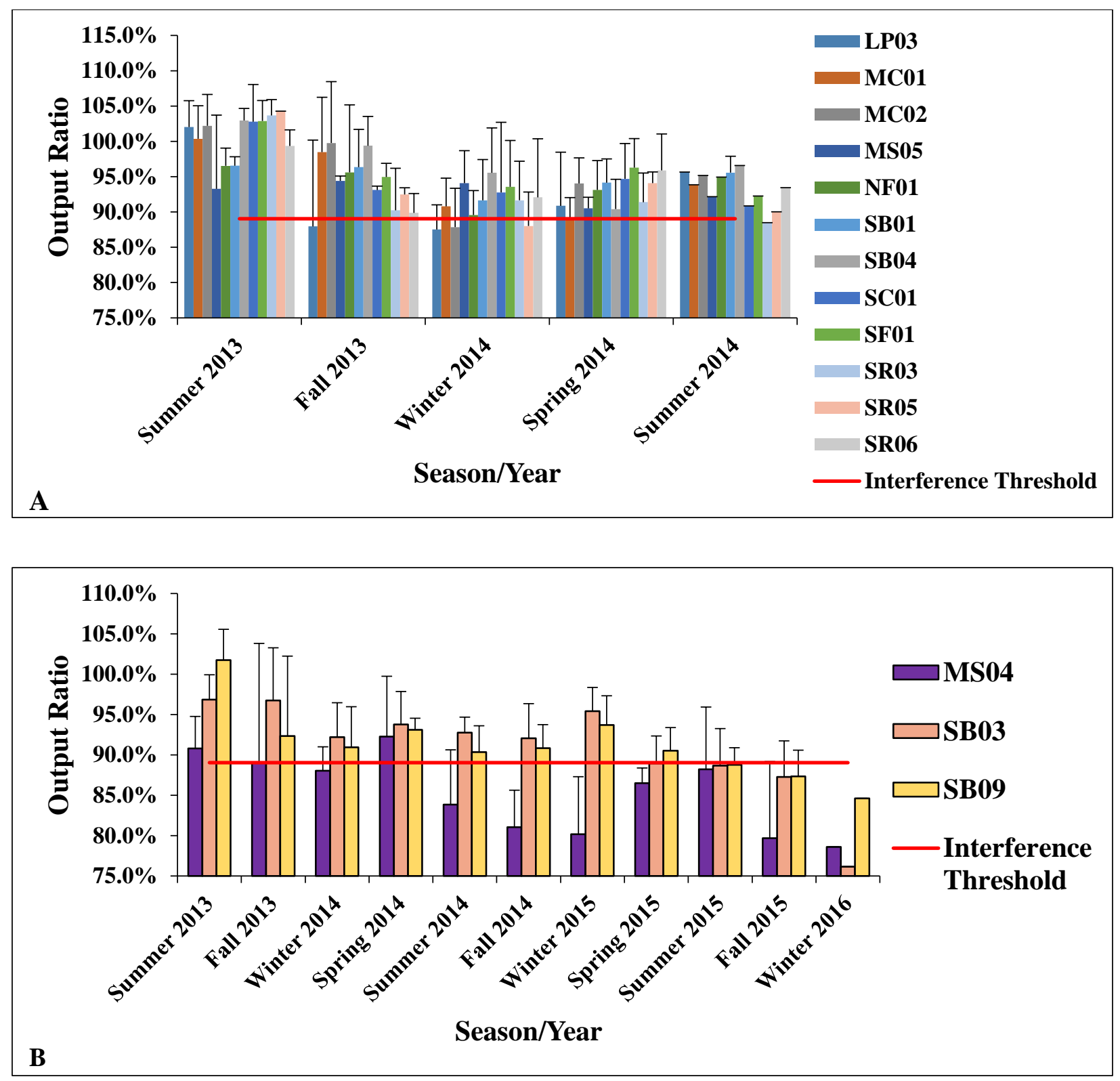
Figure 12. Season/year variability in BLYR output ratio values measured in unfiltered water samples from all sites. Error bars represent one standard deviation about the mean. The y-axis scale begins at $75 \%$ to focus on the range of values. The red bar represents the interference threshold.

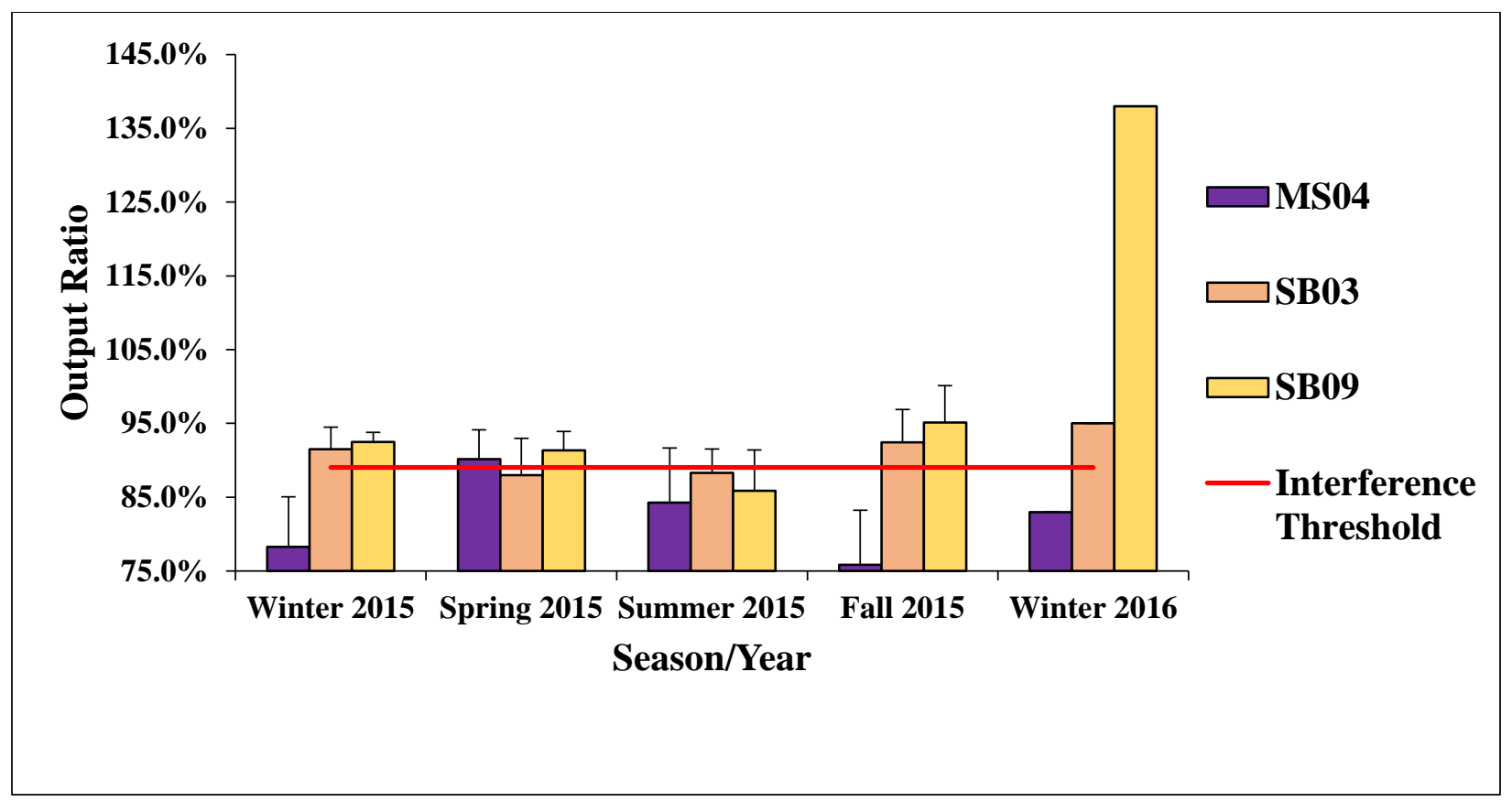


Figure 13. Season/year variability in BLYR output ratio values measured in periphyton samples from A) the reconnaissance and B) biweekly time period. Error bars represent one standard deviation about the mean. The red bar represents the interference threshold.
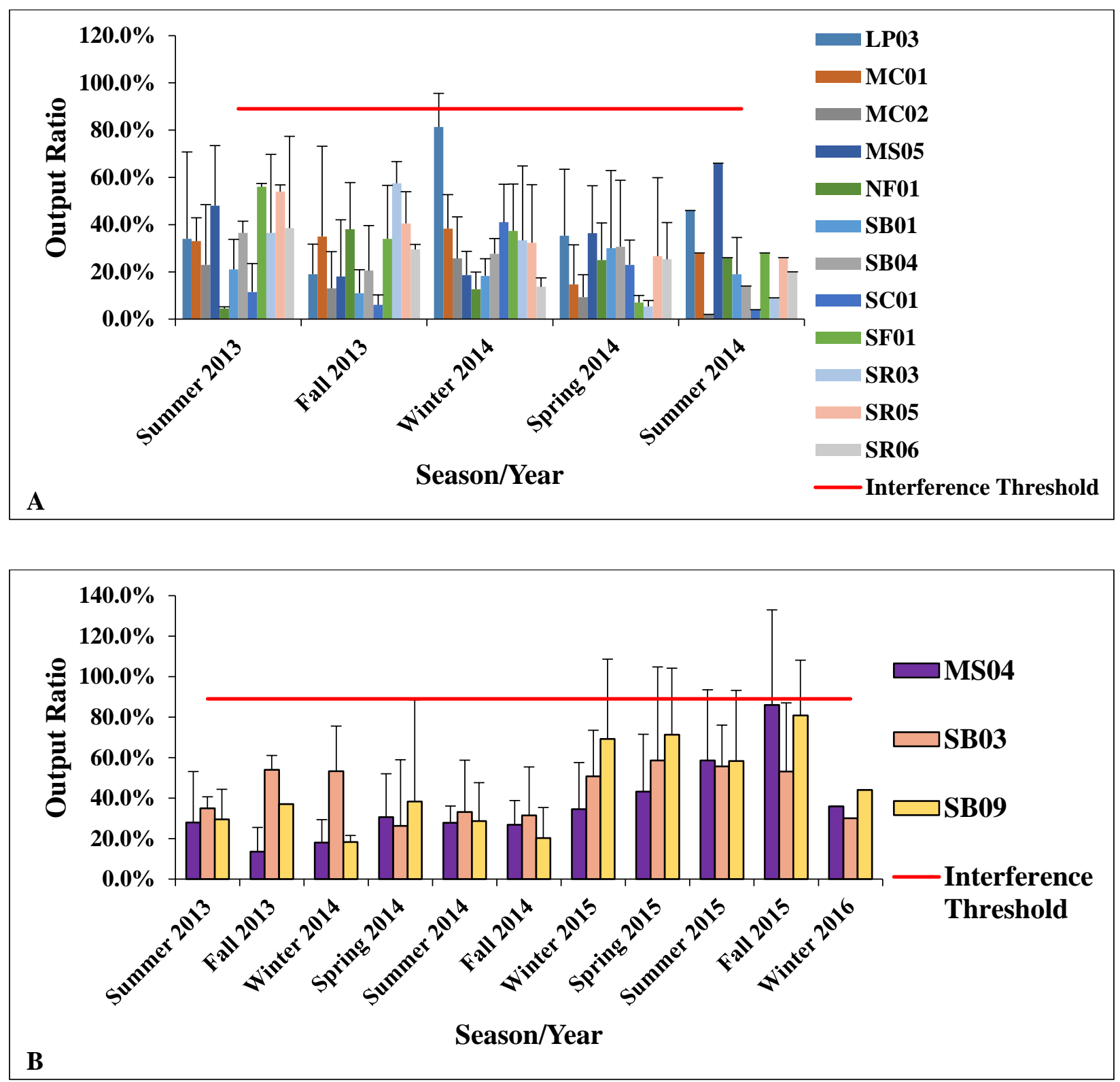
Figure 14. Daily discharge at the South Branch Potomac River near Springfield, West Virginia (U.S. Geological Survey National Water Information System ID 01608500) and the North Branch Potomac River near Cumberland, Maryland (U.S. Geological Survey National Water Information System ID 01603000).

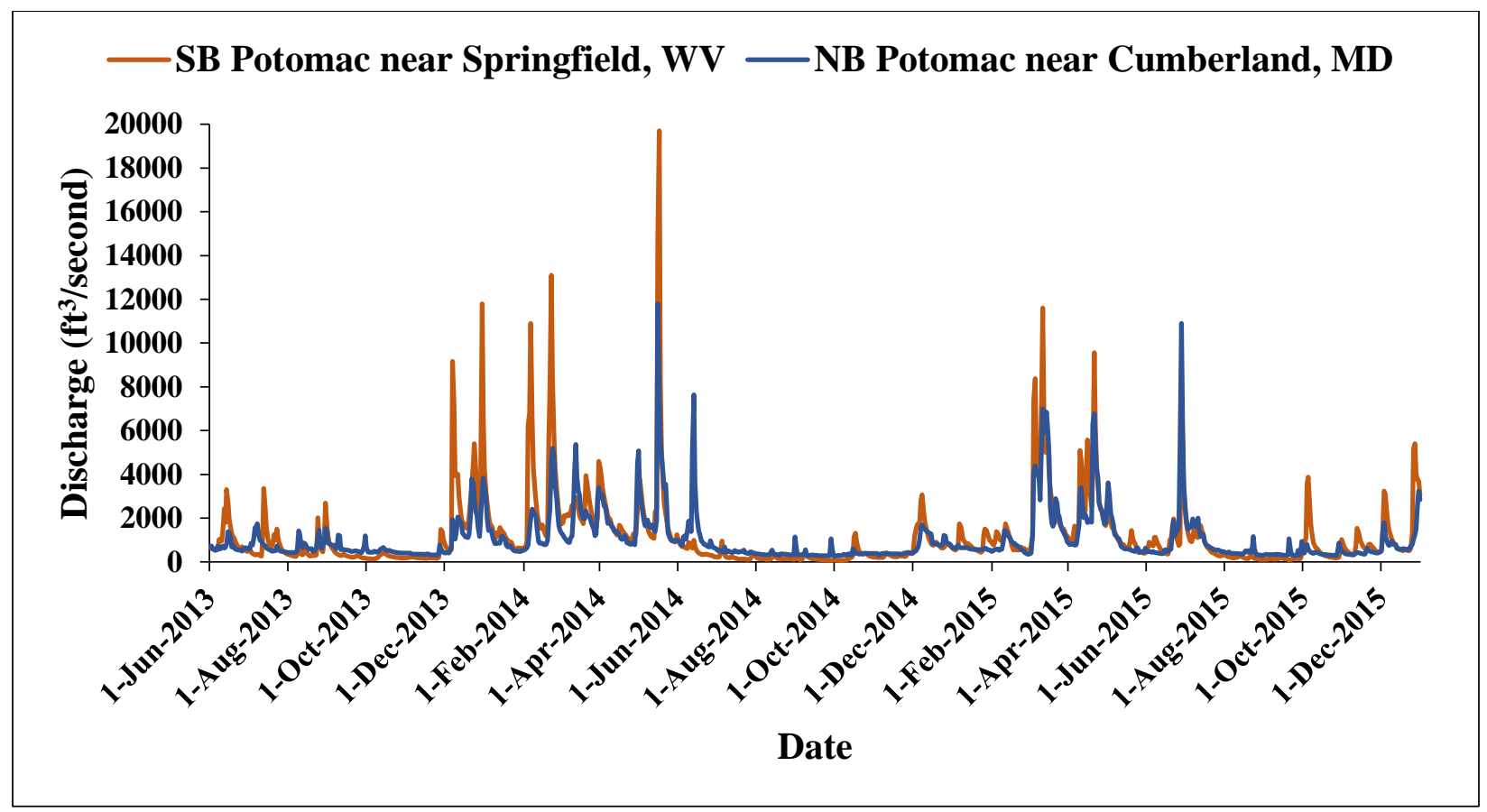




\section{Tables}

Table 1. Site description for environmental samples. Latitude and longitude are reported in decimal degrees.

\begin{tabular}{|c|c|c|c|c|c|c|c|}
\hline Basin & Site Name & $\begin{array}{c}\text { Site } \\
\text { Abbreviation } \\
\end{array}$ & $\begin{array}{l}\text { Sample } \\
\text { Site ID }\end{array}$ & Latitude & Longitude & $\begin{array}{c}\text { Reconnaissance } \\
\text { Site } \\
\end{array}$ & $\begin{array}{c}\text { Biweekly } \\
\text { Site } \\
\end{array}$ \\
\hline Monocacy River & $\begin{array}{c}\text { Monocacy River near } \\
\text { Mouth near Frederick, MD }\end{array}$ & Monocacy & LP3 & 39.38778841 & -77.37984832 & $\mathrm{X}$ & \\
\hline $\begin{array}{l}\text { North Branch of the } \\
\text { Potomac River }\end{array}$ & $\begin{array}{c}\text { Mainstem of the North } \\
\text { Branch at Cumberland, MD }\end{array}$ & $\begin{array}{l}\text { North Branch } \\
\text { Cumberland }\end{array}$ & MS4 & 39.58690227 & -78.73752192 & $X$ & $X$ \\
\hline Potomac River & $\begin{array}{c}\text { Mainstem of the Potomac } \\
\text { River near Sharpsburg, MD }\end{array}$ & $\begin{array}{c}\text { Potomac } \\
\text { Sharpsburg }\end{array}$ & MS5 & 39.41430527 & -77.74631932 & $\mathrm{X}$ & \\
\hline \multirow[t]{9}{*}{$\begin{array}{l}\text { South Branch of the } \\
\text { Potomac River }\end{array}$} & $\begin{array}{l}\text { North Fork of the South } \\
\text { Branch at Seneca Rocks, } \\
\text { WV }\end{array}$ & $\begin{array}{l}\text { North Fork } \\
\text { South Branch }\end{array}$ & NF1 & 38.83389380 & -79.37185151 & $X$ & \\
\hline & $\begin{array}{c}\text { South Fork of the South } \\
\text { Branch near Moorefield, } \\
\text { WV }\end{array}$ & $\begin{array}{l}\text { South Fork } \\
\text { South Branch }\end{array}$ & SF1 & 38.97944841 & -78.97721032 & $\mathrm{X}$ & \\
\hline & $\begin{array}{c}\text { Mainstem of the South } \\
\text { Branch at Petersburg, WV }\end{array}$ & $\begin{array}{l}\text { South Branch } \\
\text { Petersburg }\end{array}$ & SB1 & 38.99917201 & -79.08622612 & $X$ & \\
\hline & $\begin{array}{c}\text { Mainstem of the South } \\
\text { Branch near Moorefield, } \\
\text { WV }\end{array}$ & $\begin{array}{l}\text { South Branch } \\
\text { Moorefield }\end{array}$ & SB3 & 39.10406921 & -78.95770572 & $\mathrm{X}$ & $X$ \\
\hline & $\begin{array}{l}\text { Upper Mainstem of the } \\
\text { South Branch }\end{array}$ & $\begin{array}{l}\text { Upper South } \\
\text { Branch }\end{array}$ & SB4 & 38.85888361 & -79.27907259 & $X$ & \\
\hline & $\begin{array}{c}\text { Mainstem of the South } \\
\text { Branch near Mouth near } \\
\text { Springfield, WV }\end{array}$ & $\begin{array}{l}\text { South Branch } \\
\text { Springfield }\end{array}$ & SB9 & 39.50934621 & -78.60014072 & $\mathrm{X}$ & $\mathrm{X}$ \\
\hline & $\begin{array}{c}\text { Mill Creek near Dorcas, } \\
\text { WV }\end{array}$ & $\begin{array}{l}\text { Mill Creek } \\
\text { Dorcas }\end{array}$ & $\mathrm{MC} 1$ & 38.96181921 & -79.11440952 & $\mathrm{X}$ & \\
\hline & $\begin{array}{c}\text { Mill Creek near Romney, } \\
\text { WV }\end{array}$ & $\begin{array}{l}\text { Mill Creek } \\
\text { Romney }\end{array}$ & MC2 & 39.32716127 & -78.79627972 & $\mathrm{X}$ & \\
\hline & $\begin{array}{c}\text { Seneca Creek near Seneca } \\
\text { Rocks, WV }\end{array}$ & Seneca Creek & $\mathrm{SC} 1$ & 38.83423291 & -79.37175894 & $X$ & \\
\hline $\begin{array}{l}\text { North Fork of the } \\
\text { Shenandoah River }\end{array}$ & $\begin{array}{l}\text { North Fork of the } \\
\text { Shenandoah River at } \\
\text { Strasburg, VA } \\
\end{array}$ & $\begin{array}{l}\text { North Fork } \\
\text { Shenandoah }\end{array}$ & SR3 & 38.97431587 & -78.35507539 & $X$ & \\
\hline $\begin{array}{l}\text { South Fork of the } \\
\text { Shenandoah River }\end{array}$ & $\begin{array}{c}\text { South Fork of the } \\
\text { Shenandoah River at Front } \\
\text { Royal, VA }\end{array}$ & $\begin{array}{l}\text { South Fork } \\
\text { Shenandoah }\end{array}$ & SR5 & 38.92916661 & -78.21976819 & $X$ & \\
\hline Shenandoah River & $\begin{array}{c}\text { Shenandoah River at } \\
\text { Millville, WV }\end{array}$ & $\begin{array}{l}\text { Shenandoah } \\
\text { Millville }\end{array}$ & SR6 & 39.27474127 & -77.78561892 & $\mathrm{X}$ & \\
\hline
\end{tabular}


Table 2. BLYR output ratio and flow cytometry summary. MeOH and DMSO percent's are compared to the Media only positive control. The E2 and environmental samples were compared to the $2.5 \% \mathrm{MeOH}$ samples. Dead cells are defined as propidium iodide positive. Percent dead cells were adjusted to correct for background as reported in the positive control. Standard deviation id presented as SD.

\begin{tabular}{|c|c|c|c|c|c|}
\hline Sample Description & $\begin{array}{c}\text { BLYR } \\
\text { Percentage }\end{array}$ & $\begin{array}{c}\text { BLYR } \\
\text { Percentage } \\
\text { SD }\end{array}$ & $\begin{array}{c}\text { Adjusted } \\
\text { Percent } \\
\text { Dead } \\
\text { Cells } \\
\end{array}$ & $\begin{array}{c}\text { Cell Density } \\
\text { (cells/mL) } \\
1 * 10^{6}\end{array}$ & $\begin{array}{l}\text { Percent } \\
\text { Apoptotic- } \\
\text { like Cells }\end{array}$ \\
\hline $\begin{array}{l}\mathrm{MeOH} 50 \%(\text { Dead } \\
\text { Control) }\end{array}$ & $0.12 \%$ & $0.03 \%$ & $82.83 \%$ & 8.07 & $4.11 \%$ \\
\hline $\mathrm{MeOH} 20 \%$ & $47.88 \%$ & $8.03 \%$ & $0.64 \%$ & 8.31 & $0.35 \%$ \\
\hline $\mathrm{MeOH} 10 \%$ & $95.55 \%$ & $5.71 \%$ & $-0.47 \%$ & 5.67 & $0.03 \%$ \\
\hline $\mathrm{MeOH} 05 \%$ & $114.83 \%$ & $0.68 \%$ & $0.56 \%$ & 5.65 & $0.16 \%$ \\
\hline $\mathrm{MeOH} 2.5 \%$ & $117.58 \%$ & $0.29 \%$ & $0.78 \%$ & 6.77 & $0.07 \%$ \\
\hline $\mathrm{MeOH} 1.25 \%$ & $117.14 \%$ & $2.22 \%$ & $-1.15 \%$ & 5.94 & $0.05 \%$ \\
\hline $\mathrm{MeOH} 0.625 \%$ & $115.61 \%$ & $1.35 \%$ & $-3.40 \%$ & 5.65 & $0.00 \%$ \\
\hline $\mathrm{MeOH} 0.3125 \%$ & $109.12 \%$ & $2.79 \%$ & $0.06 \%$ & 6.39 & $0.00 \%$ \\
\hline $\begin{array}{c}\text { Media Only (Positive } \\
\text { Control) }\end{array}$ & $100.00 \%$ & $0.05 \%$ & $0.00 \%$ & 5.31 & $0.04 \%$ \\
\hline DMSO_5\% & $69.18 \%$ & $1.76 \%$ & $12.69 \%$ & 6.92 & $0.09 \%$ \\
\hline DMSO_2.5\% & $91.29 \%$ & $1.95 \%$ & $3.26 \%$ & 6.25 & $0.09 \%$ \\
\hline DMSO_1.25\% & $103.75 \%$ & $0.59 \%$ & $-2.16 \%$ & 5.79 & $0.05 \%$ \\
\hline DMSO_0.625\% & $109.21 \%$ & $1.98 \%$ & $0.63 \%$ & 4.46 & $0.05 \%$ \\
\hline DMSO_0.3125\% & $112.40 \%$ & $0.39 \%$ & $-0.27 \%$ & 6.92 & $0.05 \%$ \\
\hline DMSO_0.15625\% & $111.19 \%$ & $0.95 \%$ & $-0.31 \%$ & 5.19 & $0.00 \%$ \\
\hline DMSO_0.078125\% & $109.14 \%$ & $0.30 \%$ & $0.70 \%$ & 4.71 & $0.11 \%$ \\
\hline E2 Std $1(10 \mathrm{ng} / \mathrm{mL})$ & $64.94 \%$ & $1.11 \%$ & $-2.86 \%$ & 4.02 & $0.00 \%$ \\
\hline E2 Std $2(5 \mathrm{ng} / \mathrm{mL})$ & $61.47 \%$ & $2.28 \%$ & $0.81 \%$ & 2.54 & $0.02 \%$ \\
\hline E2 Std $3(1 \mathrm{ng} / \mathrm{mL})$ & $78.77 \%$ & $1.07 \%$ & $-2.27 \%$ & 2.86 & $0.02 \%$ \\
\hline E2 Std $4(0.5 \mathrm{ng} / \mathrm{mL})$ & $85.17 \%$ & $0.83 \%$ & $0.08 \%$ & 3.67 & $0.04 \%$ \\
\hline E2 Std $5(0.25 \mathrm{ng} / \mathrm{mL})$ & $91.97 \%$ & $3.45 \%$ & $-2.68 \%$ & 5.08 & $0.00 \%$ \\
\hline E2 Std $6(0.125 \mathrm{ng} / \mathrm{mL})$ & $97.51 \%$ & $1.96 \%$ & $-2.51 \%$ & 4.02 & $0.02 \%$ \\
\hline E2 Std $7(0.0625 \mathrm{ng} / \mathrm{mL})$ & $99.06 \%$ & $0.87 \%$ & $-2.75 \%$ & 4.81 & $0.00 \%$ \\
\hline E2 Std $8(0.03125 \mathrm{ng} / \mathrm{mL})$ & $97.93 \%$ & $0.35 \%$ & $-1.75 \%$ & 3.83 & $0.06 \%$ \\
\hline
\end{tabular}




\begin{tabular}{|c|c|c|c|c|c|}
\hline Sample Description & $\begin{array}{c}\text { BLYR } \\
\text { Percentage }\end{array}$ & $\begin{array}{c}\text { BLYR } \\
\text { Percentage } \\
\text { SD }\end{array}$ & $\begin{array}{c}\text { Adjusted } \\
\text { Percent } \\
\text { Dead } \\
\text { Cells }\end{array}$ & $\begin{array}{c}\text { Cell Density } \\
\text { (cells/mL) } \\
\mathbf{1 * 1 0}\end{array}$ & $\begin{array}{c}\text { Percent } \\
\text { Apoptotic- } \\
\text { like Cells }\end{array}$ \\
\hline E2 Std 9 (0.01563 ng/mL) & $95.95 \%$ & $2.46 \%$ & $-2.52 \%$ & 4.44 & $0.00 \%$ \\
E2 Std 10 (0.00781 ng/mL) & $98.35 \%$ & $3.05 \%$ & $-3.14 \%$ & 5.67 & $0.02 \%$ \\
E2 Std 11 (0.00391 ng/mL) & $98.61 \%$ & $1.24 \%$ & $-4.45 \%$ & 5.79 & $0.00 \%$ \\
\hline Filtered Water Sample 1 & $25.41 \%$ & $3.09 \%$ & $1.24 \%$ & 4.70 & $0.04 \%$ \\
Filtered Water Sample 2 & $48.54 \%$ & $0.34 \%$ & $0.23 \%$ & 4.46 & $0.04 \%$ \\
Filtered Water Sample 3 & $44.97 \%$ & $0.82 \%$ & $0.71 \%$ & 5.43 & $0.11 \%$ \\
Filtered Water Sample 4 & $48.36 \%$ & $0.77 \%$ & $1.44 \%$ & 4.15 & $0.02 \%$ \\
Filtered Water Sample 5 & $66.41 \%$ & $1.04 \%$ & $-0.36 \%$ & 3.96 & $0.06 \%$ \\
Filtered Water Sample 6 & $68.29 \%$ & $0.39 \%$ & $0.73 \%$ & 5.08 & $0.04 \%$ \\
Filtered Water Sample 7 & $86.91 \%$ & $0.17 \%$ & $-1.67 \%$ & 4.79 & $0.00 \%$ \\
Filtered Water Sample 8 & $81.15 \%$ & $0.07 \%$ & $0.85 \%$ & 5.18 & $0.04 \%$ \\
\hline Periphyton Sample 1 & $3.21 \%$ & $0.32 \%$ & $-4.46 \%$ & 20.64 & $0.05 \%$ \\
Periphyton Sample 2 & $10.37 \%$ & $0.25 \%$ & $1.35 \%$ & 7.32 & $0.02 \%$ \\
Periphyton Sample 3 & $5.98 \%$ & $0.01 \%$ & $-0.99 \%$ & 6.39 & $0.05 \%$ \\
Periphyton Sample 4 & $24.17 \%$ & $1.35 \%$ & $-1.83 \%$ & 7.77 & $0.02 \%$ \\
Periphyton Sample 5 & $9.93 \%$ & $0.11 \%$ & $-3.76 \%$ & 12.47 & $0.10 \%$ \\
Periphyton Sample 6 & $38.39 \%$ & $0.19 \%$ & $-2.80 \%$ & 4.71 & $0.00 \%$ \\
Periphyton Sample 7 & $48.65 \%$ & $0.60 \%$ & $-3.89 \%$ & 5.67 & $0.02 \%$ \\
Periphyton Sample 8 & $48.32 \%$ & $0.06 \%$ & $-2.79 \%$ & 7.09 & $0.02 \%$ \\
\hline
\end{tabular}


Table 3. BLYR/BLYES dilution comparison. Samples were diluted to the appropriate concentration and compared to a $2.5 \% \mathrm{MeOH}$ control. Data below the detection limit of the assay are presented as BD.

\begin{tabular}{|c|c|c|c|}
\hline Sample ID & $\begin{array}{l}\text { Percent } \\
\text { Sample }\end{array}$ & BLYR & BLYES \\
\hline \multirow{3}{*}{ Filtered Water Sample 9} & $100 \%$ & $99.64 \%$ & 0.119 \\
\hline & $50 \%$ & $106.02 \%$ & 0.131 \\
\hline & $25 \%$ & $109.85 \%$ & 0.106 \\
\hline \multirow{3}{*}{ Filtered Water Sample 10} & $100 \%$ & $70.76 \%$ & 0.015 \\
\hline & $50 \%$ & $82.76 \%$ & 0.016 \\
\hline & $25 \%$ & $97.30 \%$ & 0.012 \\
\hline \multirow{3}{*}{ Filtered Water Sample 11} & $100 \%$ & $62.61 \%$ & 0.016 \\
\hline & $50 \%$ & $79.59 \%$ & 0.012 \\
\hline & $25 \%$ & $85.65 \%$ & 0.012 \\
\hline \multirow{3}{*}{ Filtered Water Sample 12} & $100 \%$ & $67.17 \%$ & $\mathrm{BD}$ \\
\hline & $50 \%$ & $86.76 \%$ & 0.005 \\
\hline & $25 \%$ & $92.17 \%$ & $\mathrm{BD}$ \\
\hline \multirow{3}{*}{ Periphyton Sample 9} & $100 \%$ & $45.27 \%$ & 0.038 \\
\hline & $50 \%$ & $63.85 \%$ & 0.055 \\
\hline & $25 \%$ & $73.34 \%$ & 0.073 \\
\hline \multirow{3}{*}{ Periphyton Sample 10} & $100 \%$ & $26.23 \%$ & $\mathrm{BD}$ \\
\hline & $50 \%$ & $44.31 \%$ & $\mathrm{BD}$ \\
\hline & $25 \%$ & $53.60 \%$ & 0.008 \\
\hline \multirow{3}{*}{ Periphyton Sample 11} & $100 \%$ & $1.18 \%$ & $\mathrm{BD}$ \\
\hline & $50 \%$ & $5.42 \%$ & $\mathrm{BD}$ \\
\hline & $25 \%$ & $23.57 \%$ & $\mathrm{BD}$ \\
\hline \multirow{3}{*}{ Periphyton Sample 12} & $100 \%$ & $46.65 \%$ & $\mathrm{BD}$ \\
\hline & $50 \%$ & $73.42 \%$ & $\mathrm{BD}$ \\
\hline & $25 \%$ & $83.27 \%$ & BD \\
\hline
\end{tabular}


Table 4. Spatial summary for each sample site. Wastewater treatment facilities presented as

\section{WWTP.}

\begin{tabular}{|c|c|c|c|}
\hline Watershed & Stream Name & $\begin{array}{l}\text { Basin Area } \\
\quad\left(\mathbf{k m}^{2}\right)\end{array}$ & $\begin{array}{c}\text { Total } \\
\text { WWTP's }\end{array}$ \\
\hline Monocacy & $\begin{array}{l}\text { Monocacy River near Frederick, } \\
\text { Maryland }\end{array}$ & 2119.41 & 24 \\
\hline $\begin{array}{l}\text { North Branch } \\
\text { Potomac }\end{array}$ & $\begin{array}{l}\text { North Branch Potomac at Cumberland, } \\
\text { Maryland }\end{array}$ & 2544.65 & 28 \\
\hline \multirow{9}{*}{$\begin{array}{l}\text { South Branch } \\
\text { Potomac }\end{array}$} & $\begin{array}{l}\text { North Fork South Branch Potomac } \\
\text { near Petersburg, West Virginia }\end{array}$ & 443.07 & 0 \\
\hline & $\begin{array}{l}\text { South Fork South Branch Potomac } \\
\text { near Moorefield, West Virginia }\end{array}$ & 673.08 & 1 \\
\hline & $\begin{array}{l}\text { South Branch Potomac below } \\
\text { Petersburg, West Virginia }\end{array}$ & 2207.83 & 4 \\
\hline & $\begin{array}{l}\text { South Branch Potomac below } \\
\text { Moorefield, West Virginia }\end{array}$ & 3115.99 & 5 \\
\hline & $\begin{array}{l}\text { South Branch Potomac below } \\
\text { Franklin, West Virginia }\end{array}$ & 778.01 & 2 \\
\hline & $\begin{array}{l}\text { South Branch Potomac near } \\
\text { Springfield, West Virginia }\end{array}$ & 3822.54 & 7 \\
\hline & $\begin{array}{l}\text { Seneca Creek at Seneca Rocks, West } \\
\text { Virginia }\end{array}$ & 176.77 & 0 \\
\hline & $\begin{array}{l}\text { Mill Creek (Grant County, West } \\
\text { Virginia) }\end{array}$ & 122.57 & 0 \\
\hline & $\begin{array}{l}\text { Mill Creek (Hampshire County, West } \\
\text { Virginia) }\end{array}$ & 120.80 & 0 \\
\hline $\begin{array}{l}\text { Mainstem } \\
\text { Potomac }\end{array}$ & $\begin{array}{l}\text { Potomac Mainstem Below Antietam } \\
\text { Creek near Sharpsburg, Maryland }\end{array}$ & 16229.73 & 87 \\
\hline \multirow{3}{*}{$\begin{array}{l}\text { Shenandoah } \\
\text { River }\end{array}$} & $\begin{array}{l}\text { North Fork Shenandoah River at } \\
\text { Strasburg, Virginia }\end{array}$ & 1981.05 & 7 \\
\hline & $\begin{array}{l}\text { South Fork Shenandoah River at Front } \\
\text { Royal, Virginia }\end{array}$ & 4230.90 & 23 \\
\hline & $\begin{array}{l}\text { Shenandoah River Mainstem near } \\
\text { Millville, West Virginia }\end{array}$ & 7852.31 & 37 \\
\hline
\end{tabular}


Table 5. Land cover summary for each sample site. These percentages represent the full watershed upstream from each sampling site. The percentage of wetland/open water are excluded.

\begin{tabular}{|c|c|c|c|c|c|c|c|c|c|}
\hline & \multicolumn{3}{|c|}{ Agricultural } & \multicolumn{3}{|c|}{ Developed } & \multicolumn{3}{|c|}{ Forested } \\
\hline Stream Name & 2013 & 2014 & 2015 & 2013 & 2014 & 2015 & 2013 & 2014 & 2015 \\
\hline $\begin{array}{l}\text { Monocacy River near } \\
\text { Frederick, Maryland }\end{array}$ & $53.05 \%$ & $52.87 \%$ & $49.68 \%$ & $12.26 \%$ & $13.00 \%$ & $12.93 \%$ & $34.09 \%$ & $33.25 \%$ & $36.43 \%$ \\
\hline $\begin{array}{l}\text { North Branch Potomac at } \\
\text { Cumberland, Maryland }\end{array}$ & $10.64 \%$ & $10.50 \%$ & $8.18 \%$ & $7.83 \%$ & $7.96 \%$ & $8.45 \%$ & $80.76 \%$ & $80.52 \%$ & $82.41 \%$ \\
\hline $\begin{array}{l}\text { North Fork South Branch } \\
\text { Potomac near Petersburg, West } \\
\text { Virginia }\end{array}$ & $10.19 \%$ & $11.63 \%$ & $8.62 \%$ & $3.88 \%$ & $3.85 \%$ & $3.79 \%$ & $85.85 \%$ & $84.47 \%$ & $87.54 \%$ \\
\hline $\begin{array}{l}\text { South Fork South Branch } \\
\text { Potomac near Moorefield, West } \\
\text { Virginia }\end{array}$ & $8.27 \%$ & $8.77 \%$ & $7.14 \%$ & $3.43 \%$ & $3.42 \%$ & $3.46 \%$ & $88.12 \%$ & $87.59 \%$ & $89.15 \%$ \\
\hline $\begin{array}{l}\text { South Branch Potomac below } \\
\text { Petersburg, West Virginia }\end{array}$ & $16.29 \%$ & $17.54 \%$ & $14.24 \%$ & $3.68 \%$ & $3.68 \%$ & $3.68 \%$ & $79.89 \%$ & $78.61 \%$ & $81.92 \%$ \\
\hline $\begin{array}{l}\text { South Branch Potomac below } \\
\text { Moorefield, West Virginia }\end{array}$ & $15.30 \%$ & $16.42 \%$ & $13.43 \%$ & $3.82 \%$ & $3.82 \%$ & $3.83 \%$ & $80.70 \%$ & $79.54 \%$ & $82.50 \%$ \\
\hline $\begin{array}{l}\text { South Branch Potomac below } \\
\text { Franklin, West Virginia }\end{array}$ & $20.89 \%$ & $21.98 \%$ & $18.76 \%$ & $4.23 \%$ & $4.13 \%$ & $4.15 \%$ & $74.81 \%$ & $73.82 \%$ & $77.01 \%$ \\
\hline $\begin{array}{l}\text { South Branch Potomac near } \\
\text { Springfield, West Virginia }\end{array}$ & $15.28 \%$ & $16.32 \%$ & $13.39 \%$ & $3.77 \%$ & $3.79 \%$ & $3.82 \%$ & $80.66 \%$ & $79.54 \%$ & $82.42 \%$ \\
\hline $\begin{array}{l}\text { Seneca Creek at Seneca Rocks, } \\
\text { West Virginia }\end{array}$ & $5.69 \%$ & $6.59 \%$ & $4.31 \%$ & $2.46 \%$ & $2.55 \%$ & $2.46 \%$ & $91.83 \%$ & $90.82 \%$ & $93.21 \%$ \\
\hline $\begin{array}{l}\text { Mill Creek (Grant County, } \\
\text { West Virginia) }\end{array}$ & $16.96 \%$ & $18.14 \%$ & $14.09 \%$ & $3.77 \%$ & $3.87 \%$ & $3.81 \%$ & $79.24 \%$ & $77.92 \%$ & $82.07 \%$ \\
\hline $\begin{array}{l}\text { Mill Creek (Hampshire County, } \\
\text { West Virginia) }\end{array}$ & $12.00 \%$ & $12.68 \%$ & $9.44 \%$ & $4.33 \%$ & $4.27 \%$ & $4.33 \%$ & $83.66 \%$ & $83.00 \%$ & $86.16 \%$ \\
\hline $\begin{array}{l}\text { Potomac Mainstem Below } \\
\text { Antietam Creek near } \\
\text { Sharpsburg, Maryland }\end{array}$ & $22.62 \%$ & $22.68 \%$ & $20.58 \%$ & $7.36 \%$ & $7.67 \%$ & $7.73 \%$ & $69.54 \%$ & $68.99 \%$ & $71.04 \%$ \\
\hline $\begin{array}{l}\text { North Fork Shenandoah River } \\
\text { at Strasburg, Virginia }\end{array}$ & $34.90 \%$ & $35.38 \%$ & $33.78 \%$ & $6.29 \%$ & $6.29 \%$ & $6.30 \%$ & $58.60 \%$ & $57.96 \%$ & $59.51 \%$ \\
\hline $\begin{array}{l}\text { South Fork Shenandoah River } \\
\text { at Front Royal, Virginia }\end{array}$ & $33.99 \%$ & $34.60 \%$ & $33.13 \%$ & $10.26 \%$ & $10.30 \%$ & $10.32 \%$ & $55.39 \%$ & $54.57 \%$ & $55.99 \%$ \\
\hline $\begin{array}{l}\text { Shenandoah River Mainstem } \\
\text { near Millville, West Virginia }\end{array}$ & $34.28 \%$ & $34.71 \%$ & $33.11 \%$ & $8.95 \%$ & $9.00 \%$ & $9.02 \%$ & $56.37 \%$ & $55.71 \%$ & $57.27 \%$ \\
\hline
\end{tabular}


Table 6. Land cover summary for each sample site. These percentages represent the land cover/land use within a 30 meter buffer on either side of streams within each watershed upstream from each sampling site. The percentage of wetland/open water are excluded.

\begin{tabular}{|c|c|c|c|c|c|c|c|c|c|}
\hline & \multicolumn{3}{|c|}{ Agricultural } & \multicolumn{3}{|c|}{ Developed } & \multicolumn{3}{|c|}{ Forested } \\
\hline Stream Name & 2013 & 2014 & 2015 & 2013 & 2014 & 2015 & 2013 & 2014 & 2015 \\
\hline $\begin{array}{l}\text { Monocacy River near } \\
\text { Frederick, Maryland }\end{array}$ & $39.23 \%$ & $38.90 \%$ & $33.79 \%$ & $11.06 \%$ & $11.49 \%$ & $11.50 \%$ & $47.17 \%$ & $45.68 \%$ & $50.71 \%$ \\
\hline $\begin{array}{l}\text { North Branch Potomac at } \\
\text { Cumberland, Maryland }\end{array}$ & $7.91 \%$ & $7.32 \%$ & $5.54 \%$ & $10.90 \%$ & $11.01 \%$ & $11.02 \%$ & $77.96 \%$ & $76.93 \%$ & $78.57 \%$ \\
\hline $\begin{array}{l}\text { North Fork South Branch } \\
\text { Potomac near Petersburg, West } \\
\text { Virginia }\end{array}$ & $15.42 \%$ & $17.42 \%$ & $12.15 \%$ & $8.02 \%$ & $8.02 \%$ & $7.94 \%$ & $76.19 \%$ & $74.38 \%$ & $79.70 \%$ \\
\hline $\begin{array}{l}\text { South Fork South Branch } \\
\text { Potomac near Moorefield, West } \\
\text { Virginia }\end{array}$ & $10.18 \%$ & $10.46 \%$ & $7.71 \%$ & $6.58 \%$ & $6.52 \%$ & $6.60 \%$ & $82.56 \%$ & $82.23 \%$ & $84.83 \%$ \\
\hline $\begin{array}{l}\text { South Branch Potomac below } \\
\text { Petersburg, West Virginia }\end{array}$ & $24.44 \%$ & $25.50 \%$ & $20.07 \%$ & $8.04 \%$ & $8.01 \%$ & $8.02 \%$ & $66.89 \%$ & $65.88 \%$ & $71.19 \%$ \\
\hline $\begin{array}{l}\text { South Branch Potomac below } \\
\text { Moorefield, West Virginia }\end{array}$ & $21.57 \%$ & $22.49 \%$ & $17.60 \%$ & $7.64 \%$ & $7.59 \%$ & $7.63 \%$ & $69.96 \%$ & $69.04 \%$ & $73.72 \%$ \\
\hline $\begin{array}{l}\text { South Branch Potomac below } \\
\text { Franklin, West Virginia }\end{array}$ & $33.46 \%$ & $33.40 \%$ & $28.48 \%$ & $9.65 \%$ & $9.49 \%$ & $9.50 \%$ & $56.64 \%$ & $56.82 \%$ & $61.74 \%$ \\
\hline $\begin{array}{l}\text { South Branch Potomac near } \\
\text { Springfield, West Virginia }\end{array}$ & $21.09 \%$ & $21.87 \%$ & $17.08 \%$ & $7.38 \%$ & $7.35 \%$ & $7.38 \%$ & $69.93 \%$ & $69.06 \%$ & $73.62 \%$ \\
\hline $\begin{array}{l}\text { Seneca Creek at Seneca Rocks, } \\
\text { West Virginia }\end{array}$ & $3.36 \%$ & $3.95 \%$ & $2.51 \%$ & $8.02 \%$ & $8.05 \%$ & $8.08 \%$ & $88.53 \%$ & $87.94 \%$ & $89.38 \%$ \\
\hline $\begin{array}{l}\text { Mill Creek (Grant County, } \\
\text { West Virginia) }\end{array}$ & $18.95 \%$ & $19.61 \%$ & $13.76 \%$ & $7.30 \%$ & $7.10 \%$ & $7.24 \%$ & $73.73 \%$ & $73.22 \%$ & $78.96 \%$ \\
\hline $\begin{array}{l}\text { Mill Creek (Hampshire County, } \\
\text { West Virginia) }\end{array}$ & $16.66 \%$ & $15.85 \%$ & $10.87 \%$ & $10.41 \%$ & $10.43 \%$ & $10.40 \%$ & $72.91 \%$ & $73.69 \%$ & $78.60 \%$ \\
\hline $\begin{array}{l}\text { Potomac Mainstem Below } \\
\text { Antietam Creek near } \\
\text { Sharpsburg, Maryland }\end{array}$ & $19.65 \%$ & $19.66 \%$ & $16.69 \%$ & $8.71 \%$ & $8.84 \%$ & $8.86 \%$ & $69.36 \%$ & $68.56 \%$ & $71.42 \%$ \\
\hline $\begin{array}{l}\text { North Fork Shenandoah River } \\
\text { at Strasburg, Virginia }\end{array}$ & $32.06 \%$ & $32.56 \%$ & $30.04 \%$ & $7.15 \%$ & $7.12 \%$ & $7.11 \%$ & $59.31 \%$ & $58.05 \%$ & $60.44 \%$ \\
\hline $\begin{array}{l}\text { South Fork Shenandoah River } \\
\text { at Front Royal, Virginia }\end{array}$ & $31.58 \%$ & $32.37 \%$ & $30.15 \%$ & $10.70 \%$ & $10.62 \%$ & $10.69 \%$ & $55.27 \%$ & $53.99 \%$ & $56.01 \%$ \\
\hline $\begin{array}{l}\text { Shenandoah River Mainstem } \\
\text { near Millville, West Virginia }\end{array}$ & $30.02 \%$ & $30.57 \%$ & $28.24 \%$ & $9.25 \%$ & $9.22 \%$ & $9.25 \%$ & $58.10 \%$ & $56.98 \%$ & $59.16 \%$ \\
\hline
\end{tabular}

